TIAGO BADRE MARINO

METODOLOGIA PARA TOMADAS DE DECISÃO NO ÂMBITO DE RISCOS SÓCIO-AMBIENTAIS EM ÁREAS URBANAS: DESMORONAMENTOS E ENCHENTES EM ASSENTAMENTOS PRECÁRIOS NA BACIA DO CÓRREGO CABUÇU DE BAIXO - SP

São Paulo 
TIAGO BADRE MARINO

\section{METODOLOGIA PARA TOMADAS DE DECISÃO NO ÂMBITO DE RISCOS SÓCIO-AMBIENTAIS DE ÁREAS URBANAS: DESMORONAMENTOS E ENCHENTES EM ASSENTAMENTOS PRECÁRIOS NA BACIA DO CÓRREGO CABUÇU DE BAIXO - SP}

Dissertação apresentada à Escola Politécnica da Universidade de São Paulo para obtenção do título de Mestre em Engenharia

Área de Concentração:

Engenharia de Transportes

Orientador:

Prof. Dr. José Alberto Quintanilha

São Paulo 
Este exemplar foi revisado e alterado em relação à versão original, sob responsabilidade única do autor e com a anuência de seu orientador.

São Paulo, de junho de 2008.

Assinatura do autor

Assinatura do orientador

FICHA CATALOGRÁFICA

Marino, Tiago Badre

Metodologia para tomadas de decisão no âmbito de riscos sócio-ambientais de áreas urbanas : desmoronamentos e enchentes em assentamentos precários na bacia do Córrego Cabuçu de Baixo - SP / T.B. Marino. -- ed.rev. -- São Paulo, 2008. $138 \mathrm{p}$.

Dissertação (Mestrado) - Escola Politécnica da Universidade de São Paulo. Departamento de Engenharia de Transportes.

1. Engenharia de transportes 2. Desastres ambientais (Prevenção e controle) 3. Deslizamento de terra 4. Enchentes urbanas 5. Espaço urbano 6. Qualidade de vida I. Universidade de São Paulo. Escola Politécnica. Departamento de Engenharia de Transportes II. $t$. 


\section{AGRADECIMENTOS}

Ao Professor e orientador científico desta dissertação, José Alberto Quintanilha, pelo seu apoio e conhecimentos transmitidos durante 0 desenvolvimento e também ao compromisso assumido e empenho que dedicou a este trabalho. Agradeço ainda, a análise de cada capítulo, as sugestões, os esclarecimentos e comentários, sempre oportunos e que espero ter sabido aproveitar.

Á Fundação de Amparo à Pesquisa do Estado de São Paulo - FAPESP por me prover apoio técnico e financeiro para que eu pudesse estabelecer e dedicar-me totalmente aos estudos deste projeto, e por também por acreditar na temática de minha proposta de estudo.

Aos Professores Jorge Xavier da Silva e Maria Hilde de Barros Goes, meus gurus, grandes incentivadores deste caminho que hoje sigo com muita satisfação e empolgação. Serei eternamente grato aos conhecimentos transmitidos, de valor inestimável.

Ao Professor Luis César de Souza Pinto, do Departamento de Engenharia Hidráulica da Escola Politécnica, pelos ensinamentos transmitidos em seu curso, dos quais pude absorver novos e valiosos conhecimentos para este trabalho. Por toda simpatia, atenciosidade e colaboração na disponibilização de dados da região de estudo, quando lhes foram solicitados e também pelas críticas construtivas proferidas em meu Exame de Qualificação.

Ao Geógrafo Oswaldo Elias Abdo, por acompanhar de perto e auxiliar-me na aquisição de conhecimentos geográficos para a elaboração dos mapeamentos e do sistema VISTA/SAGA.

Aos meus colegas do Laboratório de Geoprocessamento por participarem e colaborarem ativamente na minha vida acadêmica e profissional.

À Secretaria do Departamento de Engenharia de Transportes da Escola Politécnica da USP, Srta. Simone, pelo constante e eficiente apoio na solução de questões burocráticas junto à Universidade.

Por último, porém não menos importante, à minha família e eterna companheira Sabrina, por me darem forças para seguir em frente, e pela paciência... 


\section{RESUMO}

De acordo com levantamento realizado pelo Instituto de Pesquisas Tecnológicas do Estado de São Paulo - IPT, os acidentes graves relacionados com deslizamentos atingem de forma recorrente um número relativamente pequeno dos 5.563 municípios brasileiros, girando em torno de 150 os que tiveram vítimas fatais nos últimos 17 anos. Os municípios mais vulneráveis localizam-se nos estados de São Paulo, Rio de Janeiro, Minas Gerais, Santa Catarina, Pernambuco, Alagoas, Bahia e Espírito Santo, localidades, na maioria dos casos, habitadas por pessoas de baixa renda, tornando-se, por conseguinte, expostas a catástrofes ambientais constantes (inundações devido ao assoreamento dos rios e erosão dos solos, os incêndios causados por instalações elétricas problemáticas, deslizamentos de terras, causadas por encostas irregulares e descalçamentos, entre outros). A Bacia Hidrográfica do Córrego Cabuçu de Baixo é um típico exemplo do que aconteceu em muitas cidades brasileiras. É uma bacia em acelerado processo de urbanização, mas ainda em condições para o controle, se bem administrada pelos seus gestores. Este trabalho objetiva a criação de mapeamentos que retratem avaliação positiva das condições ambientais (que pode ser chamado de "potencial") ou negativa (genericamente chamados de "risco" ambiental). Estes mapeamentos, de alto valor agregado por se originarem, via de regra, de discussões e concordâncias entre profissionais das diferentes modalidades da pesquisa ambiental - geógrafos, geólogos, biólogos, arquitetos e engenheiros, em geral - passam a constituir um valioso acervo de conhecimentos específicos da área estudada; a combinação das avaliações de riscos com o uso atual da terra, a fim de verificar possíveis áreas críticas, ou seja, assentamentos localizados em áreas mapeadas sob iminente risco de ocorrência de inundações e desmoronamentos; o levantamento das áreas indicadas para a transposição dos assentamentos localizados em áreas críticas. Todos os procedimentos computacionais realizados foram conduzidos pela metodologia de Análise Ambiental, utilizando o sistema VISTA/SAGA/UFRJ para processamento dos mapeamentos, obtenção e validação resultados. O resultado final das avaliações ambientais realizadas produz um mapa classificado com notas entre zero e dez, onde as notas mais baixas são atribuídas às localidades mapeadas com baixo risco de ocorrências de enchentes e desmoronamentos. De forma análoga, classes com maiores notas representam localidades com ocorrência de 
assentamentos precários sob risco iminente de inundações ou deslizamentos de terra e desmoronamentos. Estes mapas são denominados como "Áreas Críticas". Também são conduzidas análises para o mapeamento de áreas indicadas para transposições de localidades situadas em áreas críticas. A sobreposição destes dois últimos mapas aponta as localidades indicadas para transposições de assentamentos sob risco iminente dos eventos analisados. Finalmente, em áreas onde ocorram assentamentos precários sob alto risco de inundações e deslizamentos, sem indicações próximas para transposições (áreas favoráveis à habitação), sugere-se a realização de investimentos em infra-estrutura (ex. Programa Favela-bairro) destes locais, a fim de evitar impactos econômicos e sociais para as famílias afetadas por este processo. Assinaturas espaciais também são realizadas a fim de quantificar as áreas de riscos mapeadas. Uma vez realizados estes estudos, os conhecimentos adquiridos, pelo uso do Geoprocessamento, sobre a realidade ambiental urbana e problemática da Bacia do Córrego Cabuçu de Baixo podem ser extrapolados, com as devidas precauções, para inúmeras outras áreas urbanas que possuam características semelhantes e enfrentam os mesmos problemas.

Palavras-chave: Engenharia. Transportes Engenharia. Geoprocessamento. Análise Ambiental. Risco de Inundações. Riscos de Deslizamentos e Desmoronamentos. Qualidade de Vida. Assentamentos Precários. Bacia do Córrego Cabuçu de Baixo. Sistema de Análise Geo-Ambiental. SAGA. 


\section{ABSTRACT}

According to studies conducted by the Institute for Technological Research of the State of Sao Paulo - IPT, major accidents related landslides hit so applicant a relatively small number of 5,563 brazilian councils, turning around of 150 who had human lives losses in the last 17 years. The most vulnerable councils are located in the states of São Paulo, Rio de Janeiro, Minas Gerais, Santa Catarina, Pernambuco, Alagoas, Bahia and Espirito Santo. These locations, most cases, inhabited by low conditions people, become, therefore, exposed to constant environmental disasters (floods due to the silting of rivers and soil erosion, fires caused by problematic electrical installations, landslides, caused by irregular slopes, among others). The drainage basin of Cabuçu de Baixo river is a typical example of what happened in many Brazilian cities. It is a basin in accelerated process of urbanization, but also in a position to control, although administered by their managers. This study aims to create mappings facing positive assessment of environmental conditions (which can be called a "potential") or negative (generically called environmental "risk"). These maps are generated from professional discussions and agreement between the many kinds of researches - geographers, geologists, biologists, architects and engineers in general - are to be a valuable collection of expertise of the studied area, the combination of risk assessments to the current land using in order to check on critical areas, ie settlements located in areas mapped with imminent risk of flooding and landslides; survey of the areas indicated for the transposition of the settlements located in critical areas. All procedures performed are conducted by the computational methodology of Environmental Analysis, using the GIS VISTA/SAGA/UFRJ, processing mappings, obtaining and validating results. The final result of environmental evaluation conducted produces a "Critical Areas" map, presenting classified notes between zero and ten, where lower notes are assigned to locations mapped with low risk of occurrence of floods and landslides. Similarly, classes with higher notes represent locations where precarious settlements are mapped under imminent risk of flooding, landslides and landslides. Analyses pointing transposition areas, according to physical factors are also conducted, aiming to locate settlements under critic areas. The overlay of these both maps point transpositions indicated for settlements located under imminent risk areas. Finally, in areas where precarious settlements occurs under high floods and landslides risks, 
without near indications for transpositions (favorable areas for housing), it is suggested to make investments in infrastructure into these places, in order to maintain the "roots" of these affected families by this process. Spatial signatures are also conducted in order to quantify the risk areas mapped. Once these studies conducted, knowledge gain by the use of Geoprocessing, applied to the reality of urban environmental problems in the Drainage Basin Cabuçu, these can be extrapolated, with the necessary precautions, to other urban areas that presents similar characteristics and faces the same problems.

Keywords: Engineering. Transport Engineering. Geoprocessing. Environmental Analysis. Flooding Risks. Landslide Risks. Quality of Life. Poor settlements. Drainage Basin of Cabuçu River. SAGA. 


\section{SUMÁRIO}

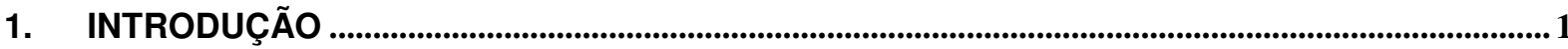

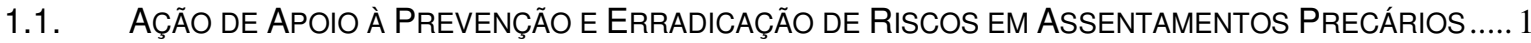

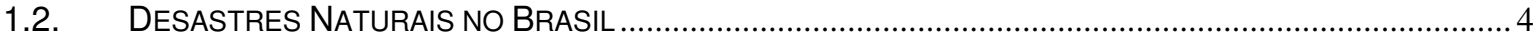

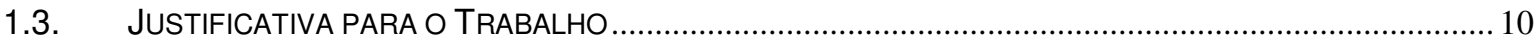

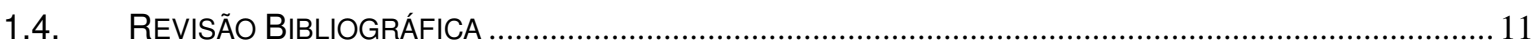

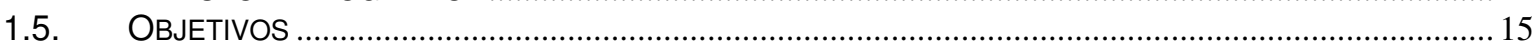

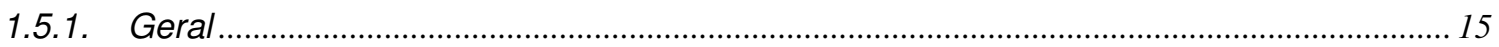

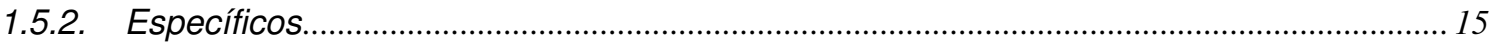

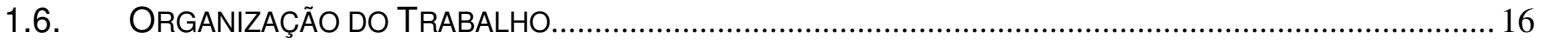

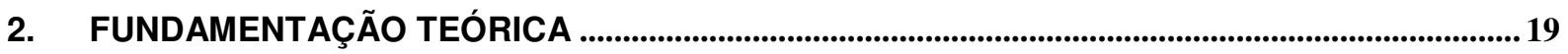

2.1. Relação entre Perigo, Risco e Desastre .......................................................................... 19

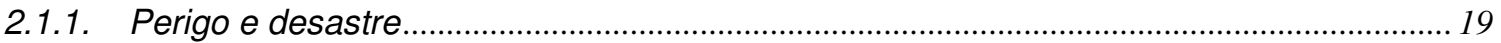

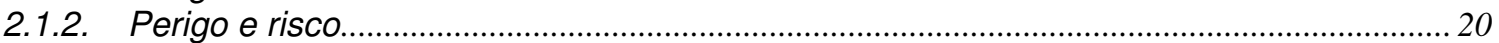

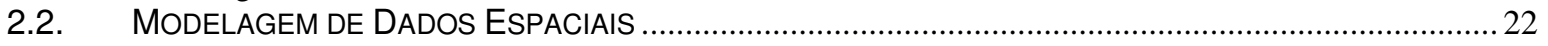

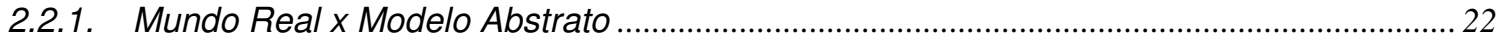

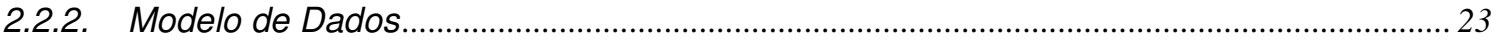

2.3. SISTEMAS DE INFORMAÇÕES GEOGRÁFICAS NA GESTÃO TERRITORIAL ........................................ 26

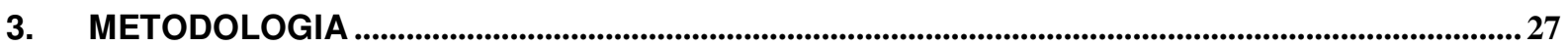

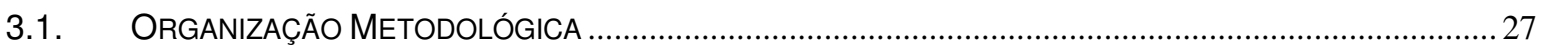

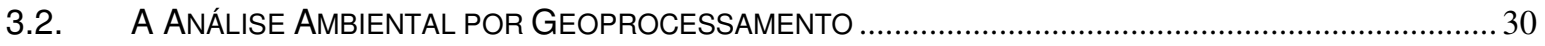

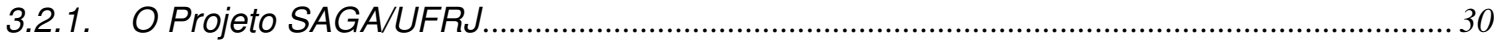

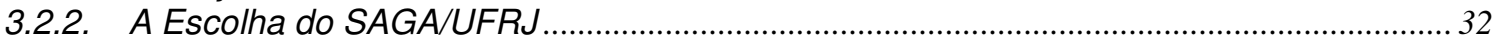

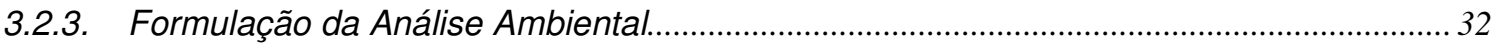

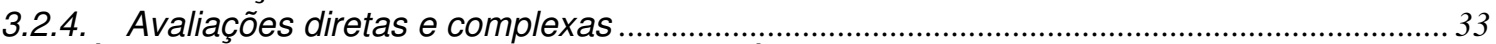

3.3. ÁRVORE DE DECISÃO: TRANSPOSIÇÕES PARA ÁREAS DE RISCOS ............................................ 40

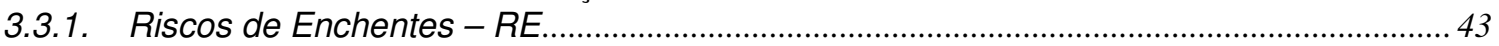

3.3.2. Riscos de Deslizamentos e Desmoronamentos - RDD ................................................... 43

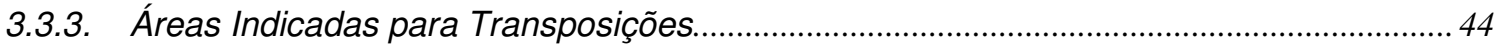

3.3.4. Qualidade de Vida (Assentamentos Precários) ....................................................................... 44

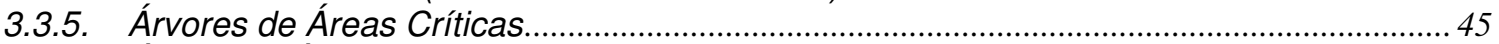

3.3.6. Árvore de Áreas Críticas para RDD e RE e Transposições Possíveis........................................ 46

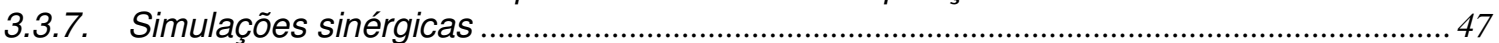

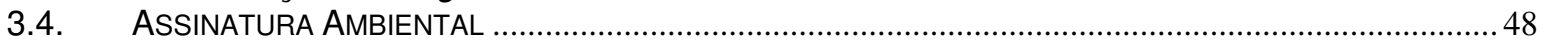

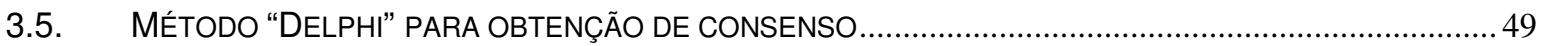

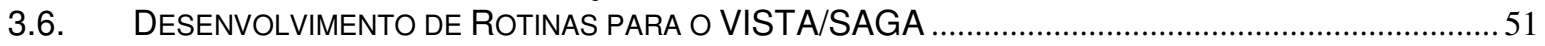

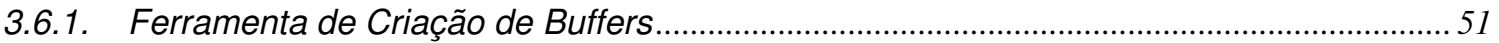

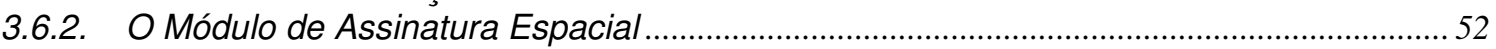

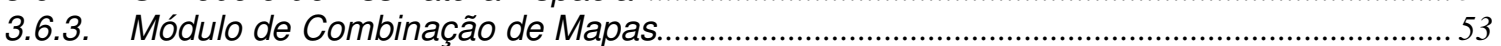

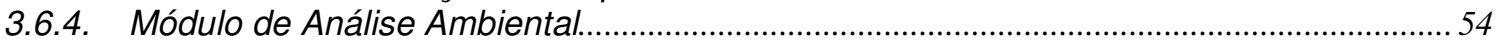

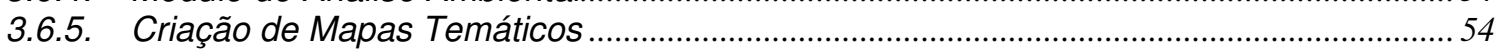

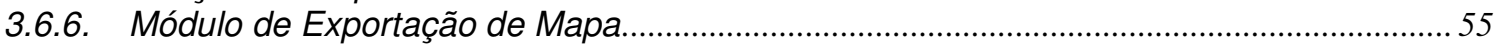

3.7. METODOLOGIA PARA A BASE DE DADOS SÓCIO-ECONÔMICA ........................................................56

3.7.1. Índices de Desenvolvimento Humano e de Qualidade de Vida.......................................... 56

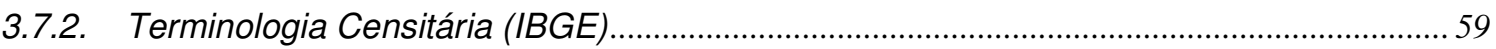

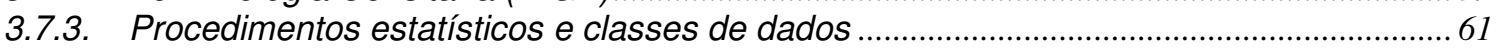

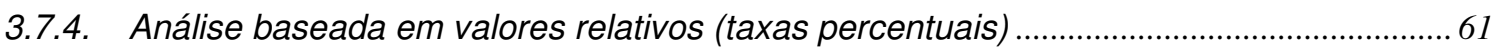

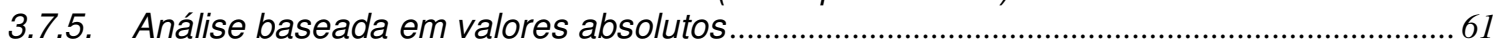

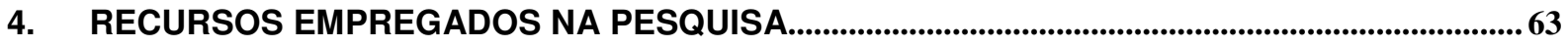

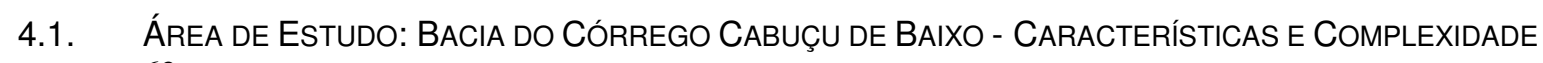
63

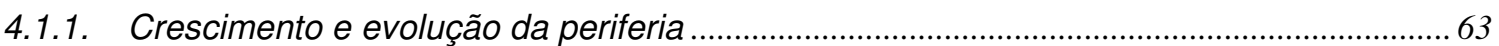

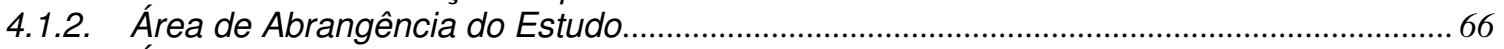

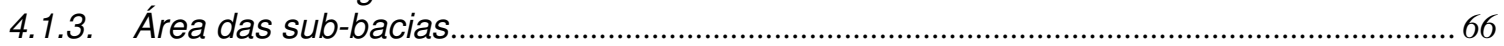

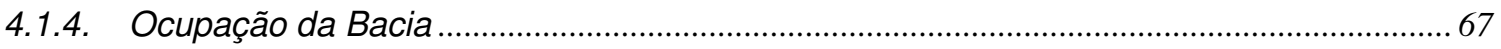

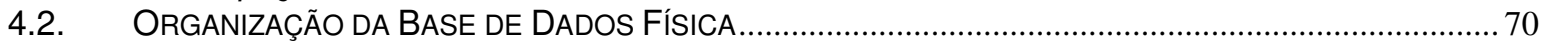




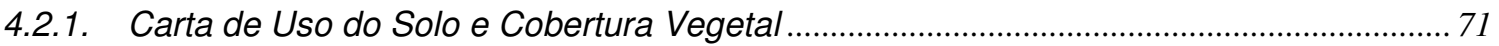

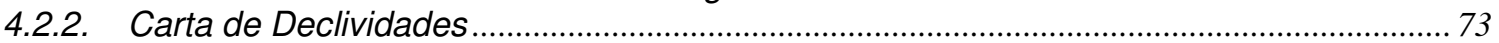

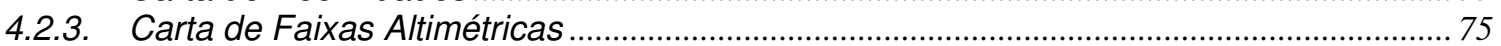

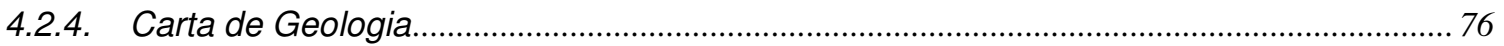

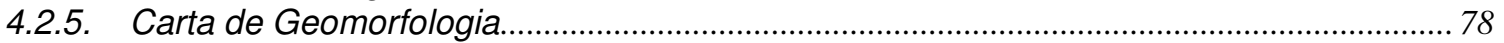

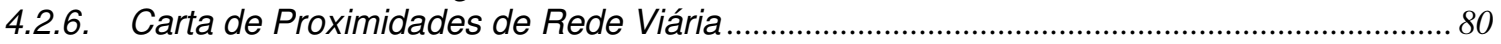

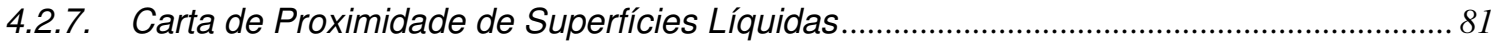

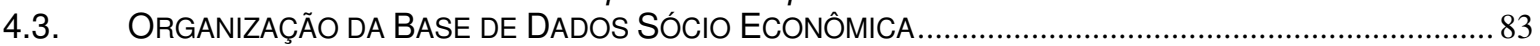

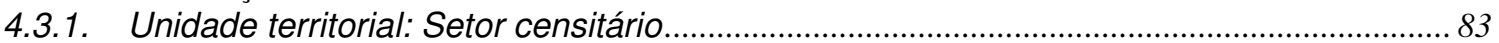

4.3.2. Infra-estrutura básica do Estado e do indivíduo à qualidade de vida .................................. 86

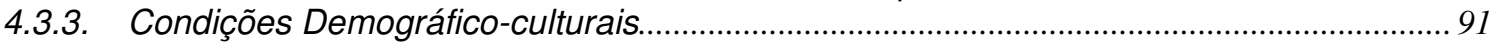

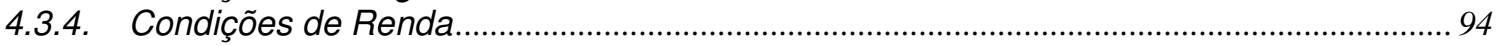

5. PROCESSAMENTOS E RESULTADOS DAS AVALIAÇÕES AMBIENTAIS ................................98

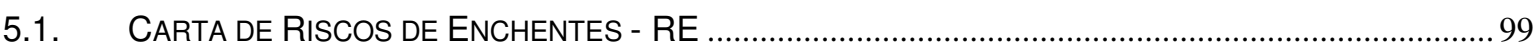

5.2. CARTA DE RISCOS DE DESLIZAMENTOS/DESMORONAMENTOS - RDD ...................................... 102

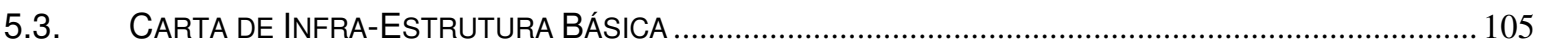

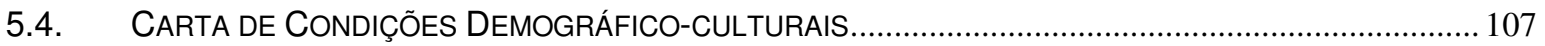

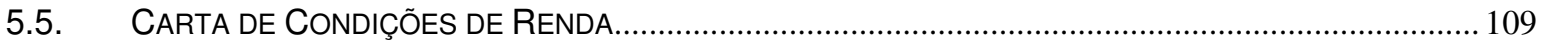

5.6. CARTA DE QUALIDADE DE VIDA / ASSENTAMENTOS PRECÁRIOS ............................................... 111

5.7. CARTA DE ÁREAS CRÍTICAS PARA RISCOS DE DESLIZAMENTOS E DESMORONAMENTOS .............. 113

5.8. CARTA DE ÁREAS CRÍTICAS PARA RISCOS DE ENCHENTES .................................................... 117

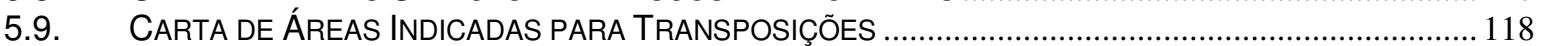

5.10. CARTA DE TRANSPOSIÇÕES PARA RISCOS DE ENCHENTES ........................................................ 122

5.11. CARTA DE TRANSPOSIÇÕES PARA RISCOS DE DESMORONAMENTOS E DESLIZAMENTOS.............. 125

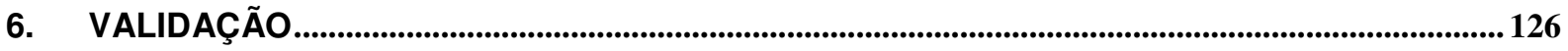

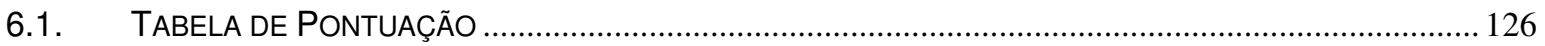

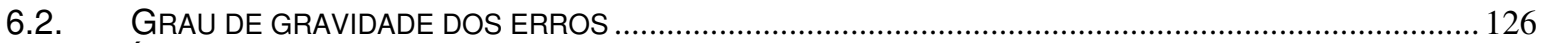

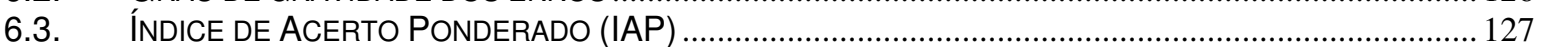

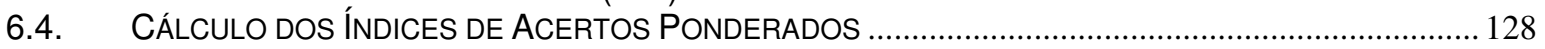

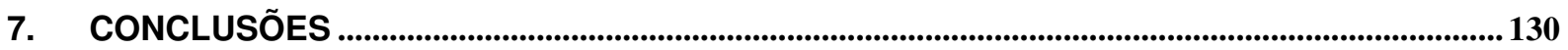

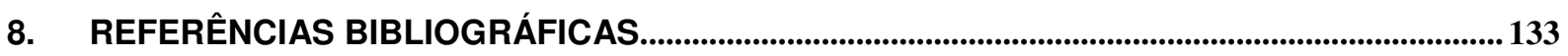




\section{LISTA DE ILUSTRAÇÕES}

Figura 1.1 - Causas do desastres ambientais na América Latina (BID, 2000) ........................................2

Figura 1.2 - Acidentes ambientais na América Latina (BID, 2000) ..................................................... 4

Figura 1.3 - Tipos de desastres naturais ocorridos no Brasil (1900-2006). Legenda: IN - Inundação,

ES - Escorregamento, TE - Tempestades, SE - Seca, TX - Temperatura Extrema, IF Incêndio Florestal e TR - Terremoto (EM-DAT, 2007).

Figura 1.4 - Distribuição dos desastres naturais no Brasil (1900-2006). Legenda: N - Norte, CO -

Centro Oeste, NE - Nordeste, SE - Sudeste, S - Sul (EM-DAT, 2007) ......................................... 6

Figura 2.1 - Relação entre perigo e desastre. Adaptado de Tobin e Montz (1997) ............................... 19

Figura 2.2 - Relação entre evento e desastres de origem natural (MARCELINO, 2007) ....................... 20

Figura 2.3 - Relação entre perigo e risco. Adaptado de Tobin e Montz (1997) ...................................... 21

Figura 2.4 - Abstração do mundo real (RODRIGUES, 2004) ................................................................... 22

Figura 2.5 - Representação do mundo real em forma de camadas (ESRI, 1990) .......................................... 25

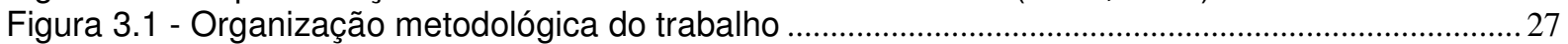

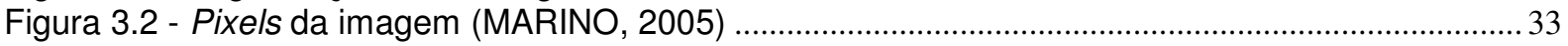

Figura 3.3 - Exemplo de caso de incongruência de uso (XAVIER DA SILVA, 2001) …......................... 37

Figura 3.4 - Exemplo de caso de potenciais conflitantes (XAVIER DA SILVA, 2001) ............................ 38

Figura 3.5 - Exemplo de caso de áreas críticas (XAVIER DA SILVA, 2001) ........................................... 39

Figura 3.6 - Árvore de decisão: Transposições de Assentamentos Precários (adaptado de XAVIER DA

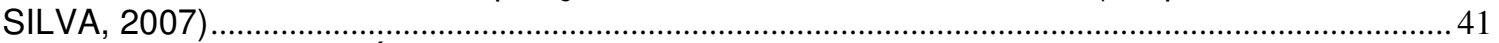

Figura 3.7 - Composição da Árvore de Riscos de Enchentes ................................................................. 43

Figura 3.8 - Composição da Árvore de Riscos de Deslizamentos e Desmoronamentos ........................ 43

Figura 3.9 - Composição da Árvore de Áreas Indicadas para Transposições ............................................. 44

Figura 3.10 - Composição da Árvore de Qualidade de Vida (Assentamentos Precários)........................... 44

Figura 3.11 - Composição das Árvores de Áreas Críticas para Riscos de Enchentes e Riscos de

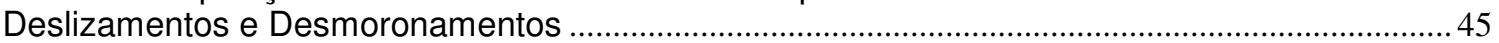

Figura 3.12 - Composição da Árvore de Áreas Críticas para RE e RDD e Transposições Possíveis .. 46

Figura 3.13 - Ferramenta Delphi, do aplicativo VISTA/SAGA definindo o peso do parâmetro

declividade numa avaliação de Riscos de Deslizamentos

Figura 3.14 - Criação de buffer de 20 metros da rede de drenagem, no Aplicativo VISTA /SAGA ...... 52

Figura 3.15 - Formato de apresentação do Relatório de Planimetria, no aplicativo VISTA/SAGA........ 53

Figura 3.16 - Procedimento de Análise Ambiental para Qualidade de Vida ............................................ 54

Figura 4.1 - Rios assoreados: degradação decorrente da ocupação sem planejamento na região

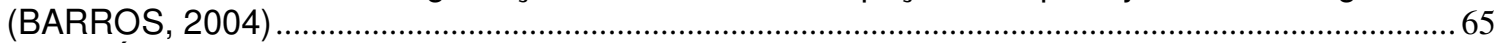

Figura 4.2 - Área de estudos: Bacia do Córrego Cabuçu e suas sub-bacias (BARROS, 2004) .............67

Figura 4.3 - Distribuição da ocupação humana na Bacia do Cabuçu de Baixo (IKONOS,2002) ........... 69

Figura 5.1 - Classes resultantes da combinação entre Qualidade de Vida x RDD .............................. 114

Figura 5.2 - Classes resultantes da Carta de Transposições para Riscos de Enchentes...................... 123 


\section{LISTA DE MAPAS}

Mapa 1 - Carta de Uso do Solo e Cobertura Vegetal (BARROS, 2004) ................................................... 72

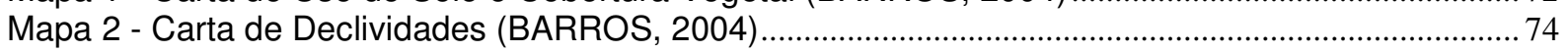

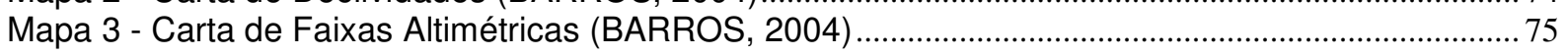

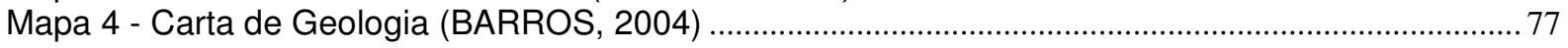

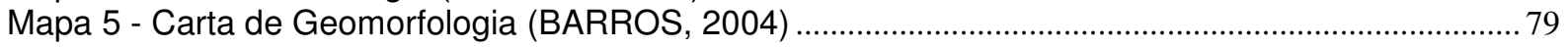

Mapa 6 - Carta de Proximidade de Rede Viária (BARROS, 2004) ......................................................... 81

Mapa 7 - Carta de Proximidade de Superfícies Líquidas (BARROS, 2004) ……...................................... 82

Mapa 8 - Carta de Delimitação dos Setores Censitários (IBGE, 2002) ………..................................... 84

Mapa 9 - Densidade Populacional por Setor Censitário (IBGE, 2002) ................................................... 86

Mapa 10 - Taxa de domicílios com abastecimento de água canalizada (IBGE, 2002) .......................... 88

Mapa 11 - Domicílios com coleta de lixo por serviço de limpeza (IBGE, 2002)....................................... 89

Mapa 12 - Domicílios conectados à rede de esgotamento sanitário (IBGE, 2002) .................................90

Mapa 13 - Número médio de habitantes por domicílio (IBGE, 2002) ..................................................... 91

Mapa 14 - Nível médio de escolaridade - Média de anos de estudo (IBGE, 2002) ................................ 92

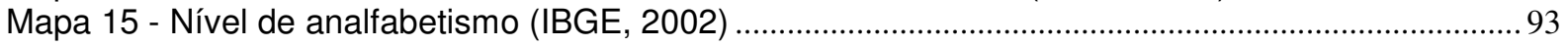

Mapa 16 - Renda média mensal da população (IBGE, 2002) ......................................................... 95

Mapa 17 - Responsáveis com renda mensal de até 1 salário mínimo (IBGE, 2002)............................. 97

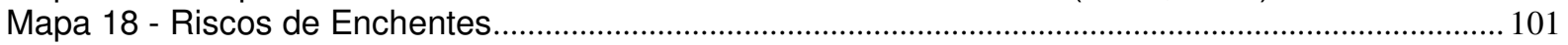

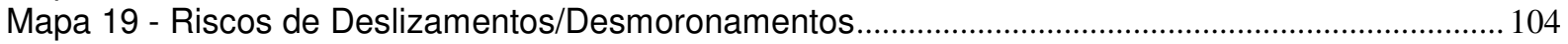

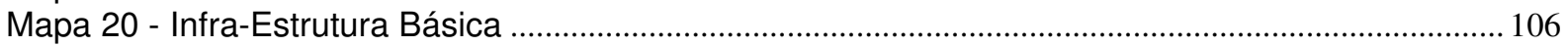

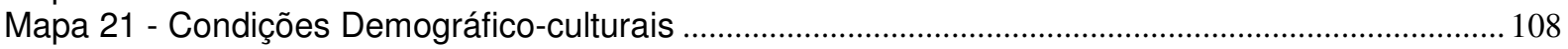

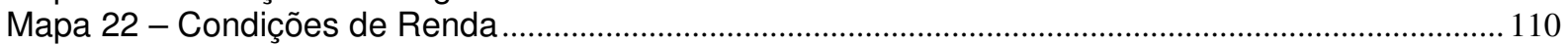

Mapa 23 - Qualidade de Vida / Assentamentos Precários...................................................................... 112

Mapa 24 - Áreas Críticas para Riscos de Desmoronamentos e Deslizamentos ................................... 115

Mapa 25 - Áreas Críticas para Riscos de Enchentes ............................................................................... 117

Mapa 26 - Áreas Indicadas para Transposições - AIT ....................................................................... 121

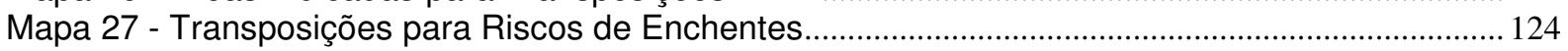

Mapa 28 - Transposições para Riscos de Desmoronamentos e Deslizamentos ..................................... 125 


\section{LISTA DE QUADROS}

Quadro 3.1 - Ilustração da necessidade de normalização das classificações

Quadro 3.2 - Ilustração de caso de análise baseada em valores absolutos ............................................. 62

Quadro 4.1 - Coordenadas delimitadoras da área de estudo................................................................6 66

Quadro 4.2 - Área das sub-bacias formadoras da bacia do Cabuçu (BARROS, 2004) ......................... 67

Quadro 4.3 - Mapas temáticos da área de estudo ................................................................................ 70

Quadro 4.4 - Classes de Declividades. Adaptado de MELO FILHO (2003) ............................................73

Quadro 4.5 - Variáveis para classificação de "Domicílios com abastecimento de água canalizada"

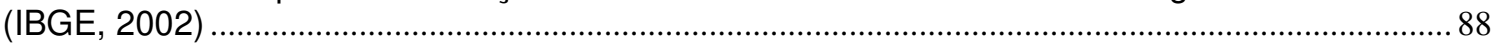

Quadro 4.6 - Variáveis para classificação de "Domicílios com coleta de lixo" (IBGE,2002) ...................89

Quadro 4.7 - Variáveis para classificação de "Domicílios com sanitário e esgotamento da rede geral" (IBGE, 2002)

Quadro 4.8 - Variáveis para classificação de "Densidade média de habitantes por domicílio" (IBGE,

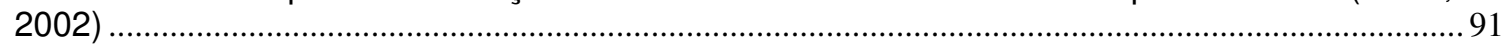

Quadro 4.9 - Variáveis para classificação de "Nível médio de escolaridade" (IBGE,2002) ...................92

Quadro 4.10 - Variáveis para classificação de "Nível de analfabetismo" (IBGE, 2002) ..........................93

Quadro 4.11 - Variáveis para classificação de "Renda média mensal da população" (IBGE, 2002) .... 94

Quadro 4.12 - Variáveis para classificação de "Responsáveis com renda mensal de até 1 salário

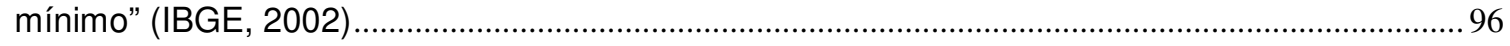

Quadro 5.1 - Pesos e notas atribuídos aos parâmetros para Riscos de Enchentes............................... 100

Quadro 5.2 - Pesos e notas atribuídos aos parâmetros para Riscos de

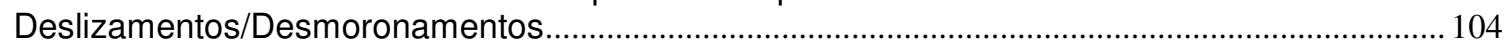

Quadro 5.3 - Pesos e notas atribuídos aos parâmetros para Infra-estrutura básica .............................. 105

Quadro 5.4 - Pesos e notas atribuídos aos parâmetros para Condições Sociais e Herança Cultural 107

Quadro 5.5 - Pesos e notas atribuídos aos parâmetros para Condições de Renda............................... 109

Quadro 5.6 - Pesos e notas atribuídos aos parâmetros para Qualidade de Vida / Assentamentos

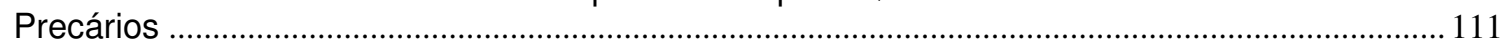

Quadro 5.7 - Agrupamentos de classes resultantes de avaliação ............................................................ 113

Quadro 5.8 - Planimetria da Carta de Áreas Críticas para Riscos de Desmoronamentos e Deslizamentos .

Quadro 5.9 - Planimetria da Carta de Áreas Críticas para Riscos de Enchentes ................................ 118

Quadro 5.10 - Pesos e notas atribuídos aos parâmetros para Áreas Indicadas para Transposições 120

Quadro 6.1 - Grupos, pesos e justificativas das ponderações para o cálculo do Índice de Acerto

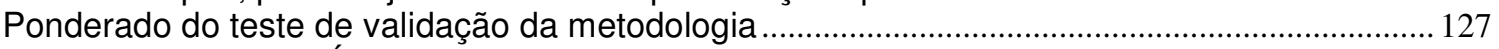

Quadro 6.2 - Cálculos dos Índices de Acertos Ponderados ................................................................. 129 


\section{INTRODUÇÃO}

\subsection{Ação de Apoio à Prevenção e Erradicação de Riscos em Assentamentos Precários}

Os principais fenômenos relacionados a desastres naturais no Brasil são os deslizamentos de encostas e as inundações, que estão associados a eventos pluviométricos intensos e prolongados, repetindo-se a cada período chuvoso mais severo.

Apesar das inundações serem os processos que produzem as maiores perdas econômicas e os impactos mais significativos na saúde pública, são os deslizamentos que geram o maior número de vítimas fatais. Este fato justifica a concepção e implantação de políticas públicas municipais específicas para a gestão de riscos de deslizamentos em encostas.

Segundo ROCHA (2005), os deslizamentos de encostas são fenômenos naturais, que podem ocorrer em qualquer área de alta declividade, por ocasião de chuvas intensas e prolongadas. Pode-se mesmo dizer que, numa escala de tempo geológica (milhares de anos), é certo que algum deslizamento vai ocorrer em todas as encostas. No entanto, a remoção da vegetação original e a ocupação urbana tendem a tornar mais frágil o equilíbrio naturalmente precário, fazendo com que os deslizamentos passem a ocorrer em escala humana de tempo (dezenas de anos ou mesmo anualmente).

Nas cidades brasileiras, marcadas pela exclusão sócio-espacial que lhes é característica, há um outro fator que aumenta ainda mais a freqüência dos deslizamentos: a ocupação das encostas por assentamentos precários, favelas, vilas e loteamentos irregulares. A remoção da vegetação, a execução de cortes e aterros instáveis para construção de moradias e vias de acesso, a deposição de lixo nas encostas, a ausência de sistemas de drenagem de águas pluviais e coleta de esgotos, a elevada densidade populacional e a fragilidade das moradias aumentam tanto a freqüência das ocorrências como a magnitude dos acidentes.

O Brasil e a América Latina, como um todo, têm sido palco de desastres ambientais crescentes. A Figura 1.1 mostra as causas desses eventos indesejáveis. 




Figura 1.1 - Causas do desastres ambientais na América Latina (BID, 2000)

No Brasil, apresentam-se como principais desastres ocorridos, por ordem de magnitude (ambiente e pessoas afetadas): a seca, as inundações, os deslizamentos e os incêndios florestais (BID, 2000).

A capacidade preventiva e resposta dos países têm sido inibidas pela falta de desenvolvimento institucional e pala não-aplicação de instrumentos dentro de um contexto de prevenção e gestão antecipada do risco. O paradigma imperante está orientado para o desenvolvimento de planos de contingência para responder emergências: esses planos se aplicavam invariavelmente sobre os efeitos e não sobre as causas. A carência de vínculos entre o planejamento do desenvolvimento, uso do território, seus recursos e a gestão do risco, conformam um panorama que reforça o círculo vicioso dos desastres (CASTRO, 2001):

- Debilidade institucional, influência de políticas públicas, legislação inadequada, pobres sistemas de informação e alerta, escassez de recursos financeiros e humanos e equipamentos ineficientes.

- Baixa qualidade de obras de infra-estrutura em conseqüência da inexistência ou a não-incorporação de normas e procedimentos de prevenção e gestão ambiental.

- Escassa preparação de população para enfrentar as ameaças e situações de desastres com mentalidade preventiva. Essa situação se complica pela carência de memória histórica sobre as causas e conseqüências de 
desastres, e com a ausência de opções para os segmentos mais pobres da população, fato que os deixa mais vulneráveis.

- A centralização de ações, com pouca participação do setor privado, a sociedade civil e governos locais, torna menos eficiente os processos de prevenção, preparação e atenção aos desastres; além disso, as dificuldades para consolidar a democracia e os problemas de governabilidade limitam seriamente o desenvolvimento dos processos preventivos.

- A prevenção nunca foi parte do discurso de políticos, os quais preferem ocupar a mídia para divulgar suas ações pós-desastres.

- Considera-se a prevenção como um custo e não como um investimento, sempre se esperando ajuda dos organismos internacionais.

- Existe uma marcante incapacidade da comunidade científica de transmitir adequadamente e de maneira convincente para os governos e população os resultados de pesquisas, os quais não chegam a se converter em argumentos a favor da prevenção.

- O crescimento demográfico é acelerado: cerca de três em cada cinco latinoamericanos vivem em condições de pobreza, e dois de cada cinco são indigentes. Impera o desemprego ou subemprego, carência de habitação, limitado acesso aos serviços básicos (educação, saúde, água, saneamento). Deve se considerar que os custos dos danos na população pobre são proporcionalmente maiores que de ouros segmentos sócio-econômicos; na maior parte dos casos essas pessoas perdem todos os seus bens, têm reduzido acesso aos serviços básicos e ao final internalizam a maior proporção das perdas.

- Existe um mito de que os desastres favorecem as economias, baseado em que, num primeiro momento, aumentam os investimentos para reconstrução pelos doadores internacionais. Na verdade, os efeitos negativos são maiores: endividamento por gastos imprevistos, desequilíbrio da balança de pagamentos, incremento das importações, desvio de recursos inicialmente planejados para investimento social, etc. 


\subsection{Desastres Naturais no Brasil}

O Brasil tem sido palco de grande número de ocorrências indesejáveis, sejam naturais, tecnológicas ou sociais. A Figura 1.2 mostra um quadro comparativo de nosso país no contexto da América Latina.

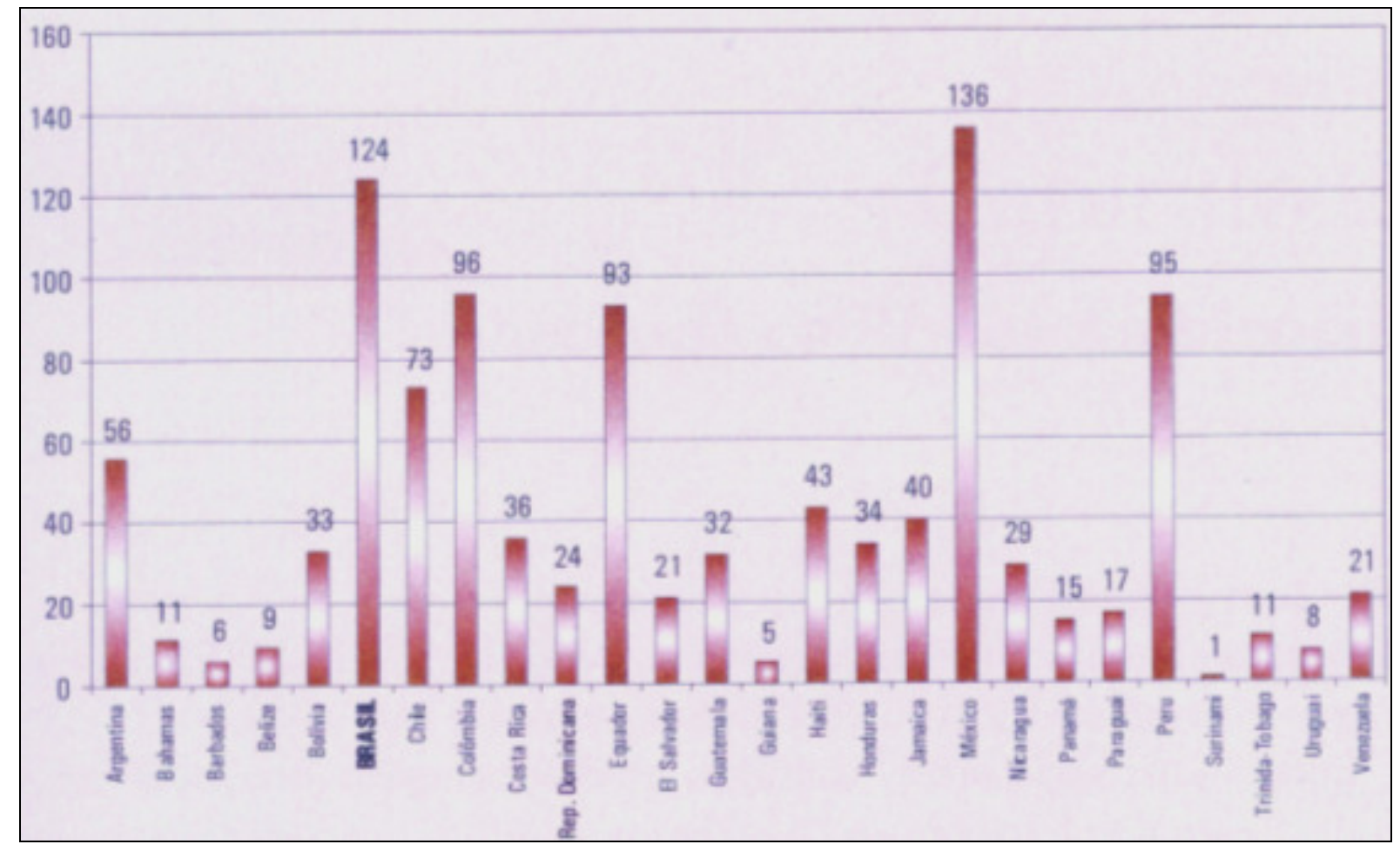

Figura 1.2 - Acidentes ambientais na América Latina (BID, 2000)

Pela Figura 1.2 pode-ser observar que nosso país se encontra em segundo lugar no ranking dos acidentes ambientais, perdendo apenas para o México, país onde, tradicionalmente têm ocorrido gravíssimos acidentes ambientais naturais e tecnológicos. O número de 124 eventos refere-se a ocorrências durante o século 20.

Conforme dados do EM-DAT (2007), ocorreram 150 registros de desastres no período 1900-2006. Do total ocorrido, $84 \%$ foram computados a partir dos anos 70 , demonstrando um aumento considerável de desastres nas últimas décadas. Como conseqüência, foram contabilizadas 8.183 vítimas fatais e um prejuízo de aproximadamente 10 bilhões de dólares.

Os tipos de desastres mais freqüentes foram as inundações (Figura 1.3), com $59 \%$ dos registros, seguidas pelos escorregamentos (14\%). A maioria dos desastres no Brasil (mais de $80 \%$ ) está associada às instabilidades atmosféricas severas, que 
são responsáveis pelo desencadeamento de inundações, vendavais, tornados, granizos e escorregamentos.

Com exceção das inundações graduais, esses fenômenos são súbitos e violentos, responsáveis por grande mortandade e destruição. Em virtude da velocidade, não há tempo para as pessoas procurarem abrigos ou salvarem parte dos bens existentes em suas casas.

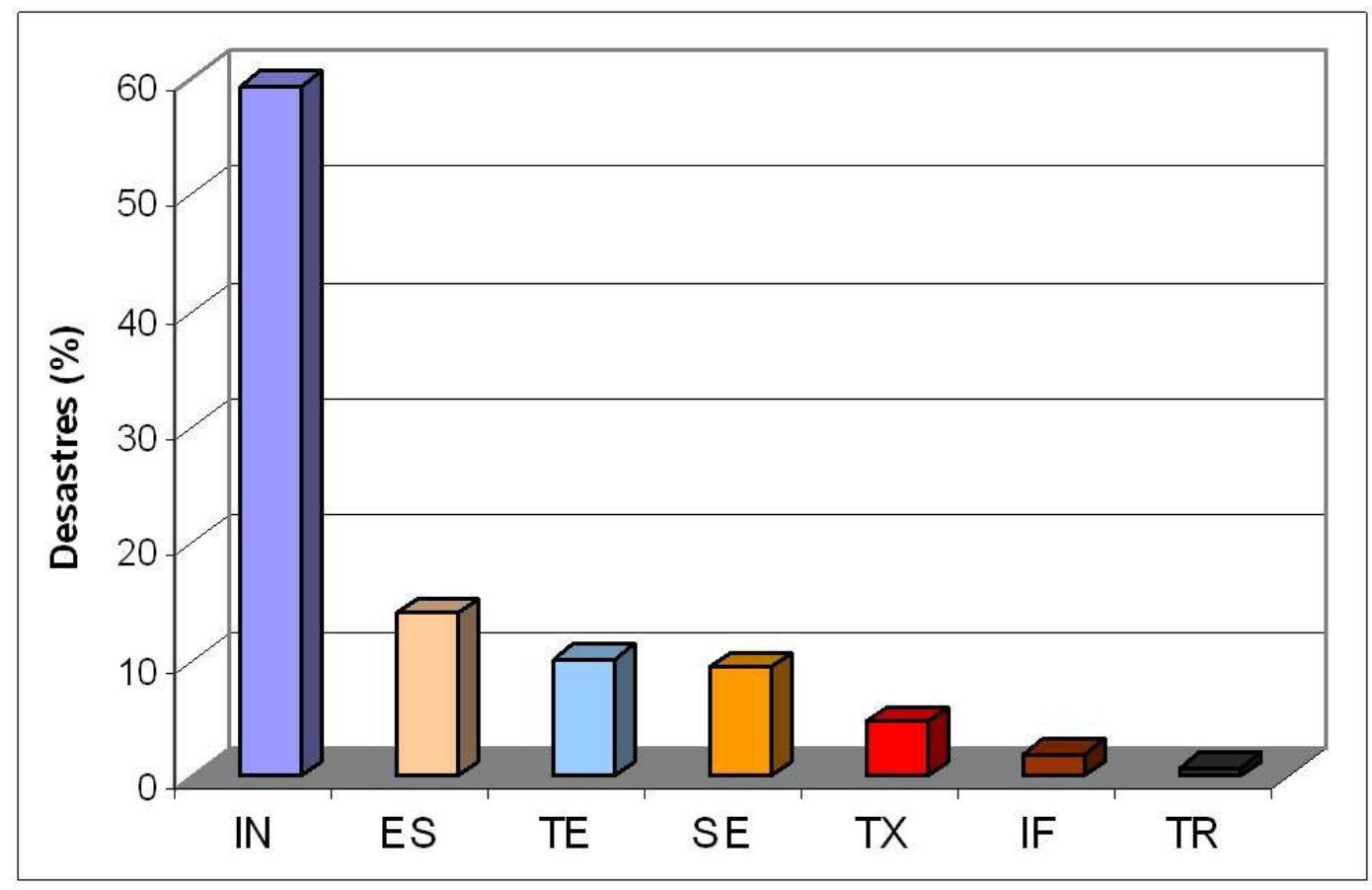

Figura 1.3 - Tipos de desastres naturais ocorridos no Brasil (1900-2006). Legenda: IN Inundação, ES - Escorregamento, TE - Tempestades, SE - Seca, TX - Temperatura Extrema, IF - Incêndio Florestal e TR - Terremoto (EM-DAT, 2007)

Com relação à distribuição espacial, mais de 60\% dos casos ocorreram nas regiões Sudeste e Sul (Figura 1.4).

Ressalta-se que são computados no banco EM-DAT, somente os desastres considerados de grande severidade, que resulta em dezenas de mortos e centenas de desabrigados, levando geralmente os estados e países a buscarem auxílio externo (MARCELINO et al., 2006; EM-DAT, 2007). Assim, o número de desastres ocorridos no Brasil é bem mais elevado do que os contabilizados no banco EM-DAT. 

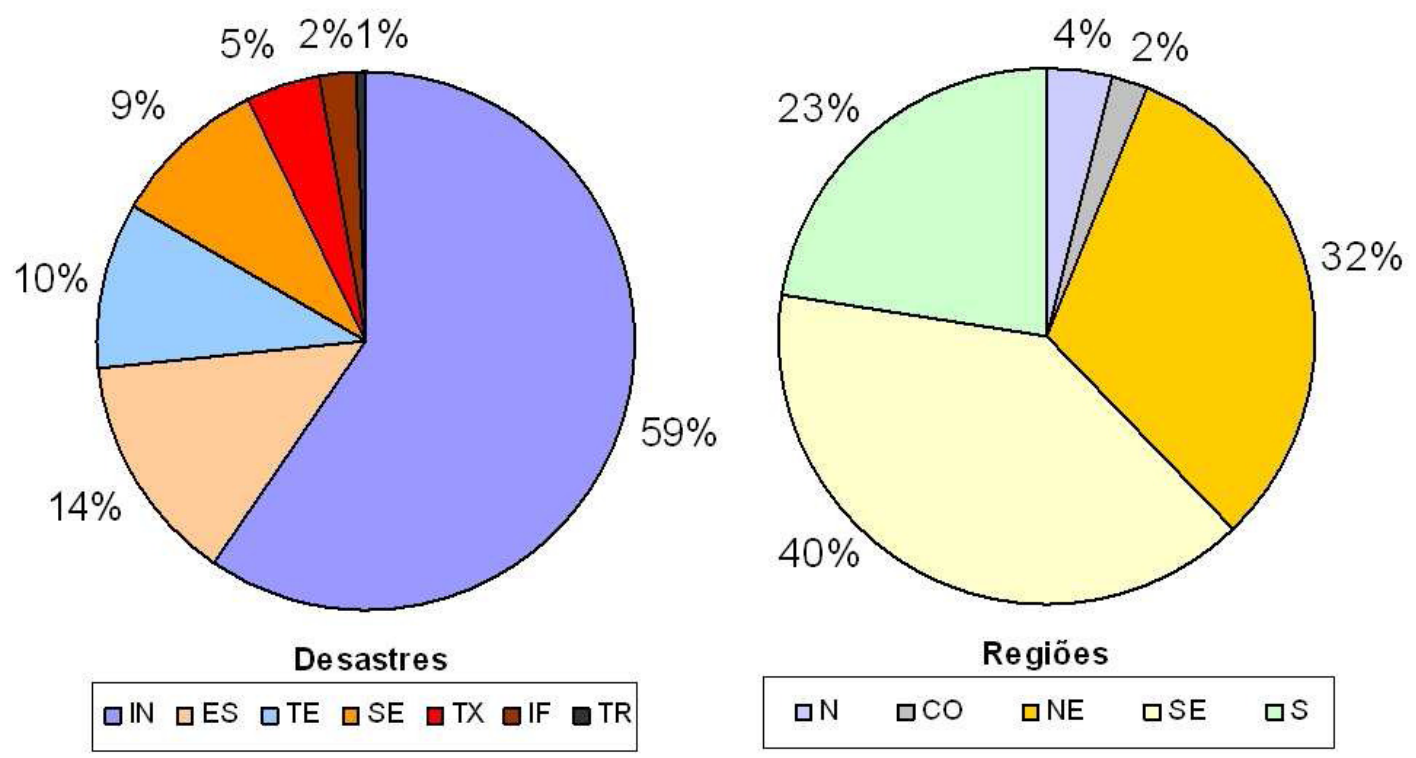

Figura 1.4 - Distribuição dos desastres naturais no Brasil (1900-2006). Legenda: N - Norte, CO - Centro Oeste, NE - Nordeste, SE - Sudeste, S - Sul (EM-DAT, 2007)

Levantamentos de riscos realizados em encostas de vários municípios brasileiros indicam que, em todos eles, a falta de infra-estrutura urbana é uma das principais causas dos fenômenos de deslizamentos no Brasil. Dessa forma, uma política eficiente de prevenção de riscos de deslizamentos em encostas deve considerar como áreas prioritárias de atuação os assentamentos precários e deve também fazer parte das políticas municipais de habitação, saneamento e planejamento urbano (CARVALHO e GALVÃO, 2006).

De acordo com levantamento realizado pelo Instituto de Pesquisas Tecnológicas do Estado de São Paulo - IPT, os acidentes graves relacionados com deslizamentos atingem de forma recorrente um número relativamente pequeno dos 5.563 municípios brasileiros, girando em torno de 150 os que tiveram vítimas fatais nos últimos 17 anos. Os municípios mais vulneráveis localizam-se nos estados de São Paulo, Rio de Janeiro, Minas Gerais, Santa Catarina, Pernambuco, Alagoas, Bahia e Espírito Santo.

Assim, se o Brasil já dispõe de conhecimento técnico, desenvolvido por meio do trabalho conjunto de universidades e institutos de pesquisas com prefeituras municipais, capaz de subsidiar a elaboração de políticas urbanas de prevenção de riscos, ainda é reduzido o número de municípios que contam, em suas políticas permanentes de desenvolvimento urbano, com a componente específica de gestão de riscos (ROCHA, 2005). 
A Cidade de Juiz de Fora (MG) foi uma das pioneiras no Brasil a colocar em prática a solicitação do Estado para elaboração do Plano Nacional de Redução de Riscos. Com cerca de 1 milhão de habitantes, a cidade apresenta um relevo bastante acidentado e vem sofrendo constantes perdas ocasionadas pelas enchentes e deslizamentos, sobretudo em função do crescente estabelecimento de moradias irregulares em encostas e ao longo da margem dos rios, cada vez mais assoreados devido à ausência de planejamento e rede de esgotamento sanitário. Segundo dados da Defesa Civil, ao longo do período chuvoso (verão) de 2005/2006 foram realizados 77 atendimentos relativos a inundações e enxurradas (DEFESA CIVIL DE JUIZ DE FORA, 2007).

Objetivando combater estas estatísticas alarmantes, a Defesa Civil de Juiz de Fora criou uma extensa programação conscientização e orientação da população local, medidas estas conhecidas como "não-estruturais" (CARVALHO, MACEDO e OGURA, 2007). Programas como "Defesa Civil vai à Escola", "Vem chuva aí, Gente!", "Turma do Chico Alerta", dentre outros (http://www.defesacivil.pjf.mg.gov.br/projetos.php) são alguns exemplos de ações proativas executadas por esta Instituição.

Ao longo do ano de 2007 o projeto SAGA/UFRJ apoiou a Defesa Civil de Juiz de Fora na elaboração do Relatório do Plano Nacional de Redução de Riscos. Por meio da aplicação da metodologia de Análise Ambiental SAGA, desenvolvida naquele Laboratório, buscou-se mapear as localidades com mais elevados riscos de ocorrências de enchentes e deslizamentos, hierarquizando-as de acordo com o grau de probabilidade de ocorrência dos eventos investigados.

Visitas técnicas em campo também foram realizadas, contando com o apoio de técnicos das mais variadas áreas: arquitetos, engenheiros, técnicos da Defesa Civil, geomorfólogos, a fim de constatar, no terreno real, a validação (ou não) dos resultados apontados pelo processamento computacional da metodologia utilizada.

Os mapas resultantes destas avaliações foram sobrepostos ao mapa de uso atual da terra (imagem de satélite da cidade daquele ano), onde se pôde mapear a ocorrência de assentamentos precários sobrepostos aos locais de mais elevados riscos. Estes são considerados os "locais críticos", ou seja, de mais altos riscos de ocorrência de enchentes e/ou desmoronamentos concomitantes com a ocorrência de ocupação humana. Tais assentamentos deverão então ser re-alocados para locais 
também apontados pelo mapa como áreas de baixos riscos, denominados como "Áreas Indicadas para Transposição".

Vale lembrar que o processo de determinação das áreas indicadas para transposições deverá sempre levar em consideração à distância do assentamento a ser re-alocado, além de outros parâmetros, como a viabilidade para implantação de infra-estrutura (rede de esgotamentos, vias públicas, rede elétrica, etc.), caso ainda não exista. Além do mais, retirar uma família de uma localidade, transportando-a para outra localidade muito distante de sua origem implicará em grandes choques para estas famílias, uma vez que suas vidas social, profissional e raízes estão todas fixadas no entorno daquela localidade, gerando, na maioria dos casos, uma resistência em retirar aquela família dali.

Portanto, faz se extremamente necessária a consideração do parâmetro distância ao se transpor uma família situada em local de risco. Em casos em que não ocorram áreas favoráveis para o reassentamento, pode-se fazer necessário até mesmo, de acordo com as possibilidades, investimentos em obras de infra-estrutura daqueles locais de maiores riscos, através de obras de saneamento, contenção de encostas, favela-bairro, buscando garantir a permanência daquelas famílias e reduzir os riscos naturais latentes naquela localidade.

Outro aspecto muitíssimo importante em todo este processo é a relação do Estado interventor com a população local. Neste sentido buscou-se sempre manter uma relação de transparência e esclarecimentos contínuos com a população local. Afinal estes serão os principais afetados ao fim deste processo. Neste sentido, a Prefeitura buscou sempre trabalhar em parceria com a população local, fazendo deles aliados através de um trabalho de assistência social, realização de 40 miniaudiências públicas em vários bairros da cidade, que mobilizaram ao todo 650 pessoas e uma audiência final contando com mais de 2 mil pessoas, buscando sempre ouvir a opinião dos envolvidos no processo.

O desafio hoje é congregar esforços de toda a sociedade para apoiar aqueles municípios que já desenvolvem políticas bem sucedidas, no sentido de potencializar seus resultados e auxiliá-los a implantar estruturas permanentes de prevenção de riscos, e, ao mesmo tempo, promover a extensão dessas experiências para o conjunto de municípios mais vulneráveis.

É com este objetivo que o Governo Federal, com a criação do Ministério das Cidades em 2003, instituiu a "Ação de Apoio à Prevenção e Erradicação de Riscos 
em Assentamentos Precários", no âmbito do Programa de Urbanização, Regularização e Integração de Assentamentos Precários. Trata-se de articular um conjunto de ações visando à redução de risco nas áreas urbanas, ações que, associando-se ao Sistema Nacional de Defesa Civil, avancem no sentido de incorporar as necessárias atividades municipais de gestão do território urbano e estejam em concordância com os programas de urbanização e regularização de favelas e loteamentos precários, áreas particularmente vulneráveis à ocorrência de desastres associados aos deslizamentos de encostas. Esta Ação compreende três modalidades, quais sejam:

- Treinamento de equipes municipais, com o objetivo de capacitar técnicos das prefeituras para a elaboração de diagnóstico, prevenção e gerenciamento de risco;

- Apoio financeiro para elaboração, pelo município, do plano de redução de risco, instrumento que planejamento que contempla o diagnóstico de risco, as medidas de segurança necessárias, a estimativa de recursos necessários, o estabelecimento de prioridades e a compatibilização com os programas de urbanização de favelas e regularização fundiária; e,

- Apoio financeiro para elaboração de projetos de contenção de encostas em áreas de risco consideradas prioritárias nos Planos Municipais de Redução de Riscos. 


\subsection{Justificativa para o Trabalho}

Acelerado processo de urbanização, mas que ainda dispõe de condições de controle, se adequadamente administrada pelos seus gestores. Este é o quadro atual da grande maioria de cidades do Brasil, sobretudo das principais capitais.

É possível, entretanto, trabalhar com a prevenção de acidentes, estabelecendo-se critérios rigorosos de segurança, aliados ao monitoramento e auditorias periódicas, assim como o estabelecimento de planos de mitigação efetivos, caso ocorra o acidente.

Em nações desenvolvidas como o Canadá, a avaliação de risco ambiental é item obrigatório nos estudos de impacto ambiental de qualquer empreendimento, sendo que os resultados dessa avaliação podem cair em uma das três seguintes possibilidades: 1. Baixíssimo risco ambiental, quando o empreendimento teria alta segurança; 2. Risco ambiental tolerável com restrições, avaliação que obriga o empreendedor a usar mecanismos e barreiras para elevar o nível de segurança; 3. Risco intolerável, quando o empreendedor não pode ser instalado, ou seja, não pode funcionar (ROCHA, 2005).

Entretanto, a resolução CONAMA 001 de 1986, legislação atualmente observada para estudo de impactos ambientais no Brasil, não exige avaliação do risco ambiental na sistematização do chamado EIA/RIMA, dispensando este importante tópico de segurança ambiental, o qual sem dúvida teria evitado, ou minimizado, os acidentes ambientais que têm ocorrido em nosso país.

A Bacia Hidrográfica do Córrego Cabuçu de Baixo é um exemplo típico do que tem ocorrido em muitas cidades brasileiras. É uma bacia em acelerado processo de urbanização, mas que ainda dispõe de condições de controle, se adequadamente administrada pelos seus gestores.

O processo de urbanização desta região ocorreu principalmente às margens do Córrego Cabuçu de Baixo. Estima-se que a aplicação da metodologia de Avaliação Ambiental proposta nesta documentação para a região poderá servir como modelo reduzido para inúmeras outras cidades submetidas a processos de ocupação desordenados, sem planejamento, resultando em gravíssimos impactos ambientais e sociais como poluição da bacia hidrográfica, assoreamento de rios, construções de habitações irregulares, insegurança, precariedade nos serviços de transporte, saúde, educação. 


\subsection{Revisão Bibliográfica}

O presente tópico versa sobre diferentes visões e abordagens de metodologias para a previsão e prevenção de riscos ambientais, através de outros autores. Nota-se um consenso, quanto à recorrente preocupação da busca de meios de previsão, redução e mitigação destes riscos cunhados "naturais" porém, potencializados pela ação humana de forma desordenada.

Ao se debruçar para o estudo de conceitos e princípios lógicos utilizados na pesquisa científica e, especialmente no geoprocessamento, XAVIER DA SILVA (2001) destaca as abordagens do Teorema de Bayes - que se baseia na probabilidade condicional, ou de indicadores, em que a ocorrência de um fenômeno é determinada, uma vez constatada a presença de um outro fenômeno a ele associado, e leva especialmente em conta o conhecimento prévio do pesquisador, que é incorporado ao sistema; da lógica booleana - que considera as regras algébricas AND, NOT, OR e XOR, e, de estrutura binária, sempre por decisão de verdadeiro ou falso para um determinado evento, permite sucessões de combinações de atributos espaciais; e da lógica Fuzzy ou nebulosa, também descrita por BONHAM-CARTER (1998), como uma função de pertinência que exprime a possibilidade de uma variável constituir um plano de informação ambiental. A lógica Fuzzy, introduzida por Lotfi Zadeh, em 1965, procura modelar os modos imprecisos do raciocínio, que têm um papel fundamental na habilidade humana de tomar decisões. Este processamento nebuloso incorpora a riqueza das informações fornecidas por especialistas (ZADEH, 1965). Ela pode ser expressa como a booleana (0 ou 1), mas, no caso de representar uma variável contínua, como os níveis de concentração de arsênico em sedimentos lacustres, há valores intermediários presentes (entre 0 e 1), que são significativos nos seus efeitos. Então, em escalas de intervalo ou razão, essa função de pertinência pode significar a possibilidade de ocorrência de determinado fenômeno ambiental.

SAHOO, JOTHIMANI e TRIPATHY (2002) apresentam o desenvolvimento de

uma árvore de decisão com a abordagem Multi-Criterial Evaluation para segmentação de áreas potenciais para exploração mineral. O procedimento produziu um mapa de potencialidade, identificando áreas favoráveis para exploração de ouro.

Outro exemplo de estudo ambiental que combina as variáveis geográficas baseando-se em localizações pontuais, foi o trabalho desenvolvido por MONTOYA 
et al (1999) na identificação de áreas de risco para inundações e movimentos de massa na bacia do Rio Buquira, afluente do Rio Paraíba, em São José dos Campos - SP.

DUNNE e LEOPOLD (1978) sugerem que, para a previsão de inundações e de seus efeitos, devem ser estudados um ou vários dos seguintes fatores: volume de escoamento superficial; descargas máximas; altura da inundação; hidrograma com a distribuição no tempo da vazão máxima e do volume escoado; área inundada; e velocidade da água.

No âmbito nacional, o Ministério das Cidades lança a publicação sobre "Mapeamento de Riscos em Encostas e Margens de Rios" (CARVALHO, MACEDO e OGURA, 2007). O trabalho orienta equipes municipais a identificar e administrar áreas de risco, num conteúdo didático e apresenta metodologia de análise de risco, desenvolvida pelo Instituto de Pesquisas Tecnológicas (IPT), direcionada à realidade das cidades brasileiras, com baixo custo de execução.

ZERGER e WEALANDS (2003), em "Beyond Modelling: Linking Models with GIS for Flood Risk Management' defendem a necessidade da obtenção de informações sobre início, duração e quantidade de períodos chuvosos como elementos chave para a criação de um modelo de redução de riscos, sendo estas, informações cruciais para o planejamento de uso da terra, mapeamento de evacuação e rotas de escape, e localização de abrigos de emergência adequados. Seus estudos baseiam-se na aplicação de um sistema de suporte à decisão, modelado pela combinação de Sistemas de Informações Geográficas conectados a um banco de dados comercial que forneça os dados pluviométricos. Os estudos foram realizados na costa norte da Austrália e os resultados mostram que o modelo reduz significativamente as perdas decorrentes destes desastres.

Em estudos mais recentes, e muito próximos da metodologia apresentada neste trabalho, pesquisadores buscam delinear áreas de riscos para enchentes por meio de sensoriamento remoto. DEWAN, KUMAMOTO e NISHIGAKI (2006) delimitam áreas de riscos a partir do mapeamento por Multi-data RADARSAT da maior enchente de 1998, ocorrida no Grande Dhaka, capital do Bangladesh. Mapas de riscos de enchentes foram criados, utilizando "ranking matrix", conjugada aos mapas de uso e cobertura do solo, fatores topográficos e geomorfológicos. O resultado do estudo aponta uma grande porção territorial da Grande Dhaka 
associada a zonas de riscos elevados de inundação, ao passo que apenas uma pequena parcela não está exposta ao risco potencial de inundação.

MELO FILHO (2003) apresenta a metodologia de mapeamentos de riscos ambientais (enchentes e desmoronamentos) e de qualidade de vida na Bacia do Canal do Mangue (cidade do Rio de Janeiro), integrando o ambiente físico ao humano. Suas análises são estruturadas numa árvore de decisão (XAVIER DA SILVA, 2001), conjugando fatores naturais e históricos, riscos por intervenção humana, infra-estrutura básica do estado e do indivíduo, condições sociais e herança cultural e conjuntura econômica como fatores contribuintes para a determinação dos diferentes níveis de riscos e qualidade de vida na região de estudo.

Segundo IBGE (2004), um dos principais desafios do desenvolvimento sustentável é o de criar instrumentos de mensuração, tais como indicadores de desenvolvimento. Por esta via,

Indicadores são ferramentas constituídas por uma ou mais variáveis que, associadas através de diversas formas, revelam significados mais amplos sobre os fenômenos a que se referem. São instrumentos essenciais para guiar a ação e subsidiar o acompanhamento e a avaliação do progresso alcançado. Cumprem muitas funções e reportam-se a fenômenos de curto, médio e longo prazos. Viabilizam o acesso à informação já disponível sobre temas relevantes para o desenvolvimento, assim como apontam a necessidade de geração de novas informações. Servem para identificar variações, comportamentos, processos e tendências, estabelecer comparações entre regiões, indicar necessidades e prioridades para a formulação, monitoramento e avaliação de políticas, e, por sua capacidade de síntese, são capazes de facilitar o entendimento sobre o tema.

Partindo desse princípio, foram criados diversos índices para se estimar os níveis de desenvolvimento e da qualidade de vida das populações, gerados a partir da iniciativa da ONU, por meio do Programa das Nações Unidas para o Desenvolvimento - PNUD, que publica desde 1990 o Relatório do Desenvolvimento Humano - Internacional, tomando como modelo padrão o Índice de Desenvolvimento Humano (IDH), para todos os países, elaborado por grupo liderado pelo cientista Mahbub ul Haq (IPEA, 1998). 
AZZONI et al (2000), ao estudarem os efeitos das políticas públicas de combate à pobreza e de melhora da distribuição de renda, destacam que o padrão de vida das famílias dependem não apenas da capacidade que têm em auferir renda, como assume o modelo neoclássico de crescimento, mas, de forma decisiva, do que denominam diferenciais de capital geográfico, constituído pelo maior aporte de recursos a áreas já consideradas privilegiadas, de forma discriminatória. Segundo FERNANDES (2002), é fato bastante documentado que parte significativa dos diferenciais de salários, e de renda, pode ser explicada por diferenças nas características observáveis das pessoas, como a educação e a experiência profissional.

HLUCHY et al (2004) apresentam um protótipo de ambiente colaborativo para resolver problemas de previsão de inundações. Segundo o autor "a previsão é um problema complexo que exige a cooperação de muitos cientistas de diferentes áreas". Para prover esta cooperação, de uma forma confortável para especialistas hidrometeorológicos, o sistema consiste numa cascata de modelos de simulação, um sistema de armazenamento de dados calculados, medições e outros dados utilizados, concentrados um portal web com a colaboração de ferramentas e um poderoso mecanismo computação que apóia e organiza uma comunidade virtual de especialistas, desenvolvedores e usuários.

Atuando ativamente em estudos e ações de apoio a desastres ambientais, estão agências como o PNUD (Programa das Nações Unidas para 0 Desenvolvimento), apoiando financeira e estruturalmente órgãos como 0 CENACID/UFPR (Centro Nacional de Apoio em Desastres), em missões de gestão e prevenção de riscos ambientais. O ISDR - International Strategy for Disaster Reduction apresenta-se como uma agência da ONU que atua intensamente na conscientização da importância da redução de desastres como componente integral do desenvolvimento sustentável e difusão de métodos preventivos e reativos contra desastres naturais, com a meta de reduzir perdas humanas, sociais, econômicas e ambientais, devido aos riscos naturais e tecnológicos relacionados e catástrofes ambientais (ISDR, 2007).

Em XAVIER DA SILVA e ZAIDAN (2004) destacam-se os inúmeros exemplos práticos do uso da metodologia de avaliação ambiental na produção de conhecimento de suporte a políticas públicas. Ainda apresenta abordagens sobre análise ambiental no contexto do geoprocessamento através de trabalhos que 
refletem a experiência científica e acadêmica de seus autores, demonstrando grandes avanços no Brasil na área em questão. Embora os capítulos se refiram às aplicações do sistema de informações geográficas SAGA/UFRJ, o conjunto da obra foi concebido de modo a estimular as mais variadas formas de utilização da sua metodologia de análise ambiental.

Dentro deste contexto de soluções, sugere-se a atenção para o trabalho "Low cost Housing on Slopes" (MARCH, 2006), atendendo como uma alternativa de construção de forma segura e bem estruturada em encostas, apresentando-se como ótima solução para re-construção nestas áreas consideradas "intransponíveis".

CARVALHO e GALVÃO (2006) apresentam em "Prevenção de Riscos de Deslizamentos em Encostas: Guia para Elaboração de Políticas Municipais" algumas soluções propostas pelo Estado para gerenciamento de áreas críticas.

\subsection{Objetivos}

\subsubsection{Geral}

Desenvolvimento e aplicação de metodologia para avaliação ambiental, utilizando ferramentas de análise espacial e sistemas de informações geográficas, que permitam a:

- Criação de mapeamentos avaliativos que retratem as condições ambientais positivas (que podem ser denominadas "potencialidades" ou, mais sinteticamente, "potenciais") ou negativas (genericamente denominadas "riscos" ambientais) de uma determinada área de estudo. Estes mapeamentos, de alto valor agregado por se originarem, via de regra, de discussões e concordâncias entre profissionais das diferentes modalidades da pesquisa ambiental - geógrafos, geólogos, biólogos, arquitetos e engenheiros, em geral - constituem um valioso acervo de conhecimentos específicos da área estudada, passando a fazer parte, juntamente com os mapas temáticos básicos usados para obtê-los, de um inventário ambiental sobre a área de estudo;

\subsubsection{Específicos}

- Identificação de possíveis áreas críticas (assentamentos situados em áreas avaliadas com risco iminente para a ocorrência de enchentes e/ou desmoronamentos) na Bacia do Córrego Cabuçu de Baixo (SP) através da 
combinação das avaliações de riscos com o mapeamento de Qualidade de Vida.

- Identificação de áreas indicadas para transposição, próximas dos assentamentos localizados em áreas críticas.

- Utilização do aplicativo VISTA/SAGA como ferramenta para a elaboração dos mapeamentos sócio-econômicos e processamento das avaliações ambientais propostas.

- Validação da metodologia por meio de cotejamento com o mapeamento pontual do histórico de ocorrência de enchentes, deslizamentos e desmoronamentos na região a fim de verificar a congruência (ou não) de áreas consideradas de baixo, médio e alto riscos nos pontos de amostragem provenientes deste histórico.

\subsection{Organização do Trabalho}

Para maior ordenamento e compreensão, esta Dissertação foi dividida em 8 capítulos, entre os quais se insere esta Introdução, onde são apresentados os Objetivos, em que se destacam as etapas para se atingir a análise da variação territorial da qualidade ambiental e riscos potenciais na Região da Bacia do Córrego Cabuçu de Baixo - São Paulo.

O capítulo 2 reserva-se à Fundamentação Teórica, onde são introduzidos alguns conceitos básicos, baseados na literatura, de riscos e áreas de riscos. Discute-se também a importância da utilização dos Sistemas Geográficos de Informações (SIGs), descrevendo sua arquitetura de composição, além da importância e exemplos de aplicações providos pelos SIGs, num contexto de gestão territorial.

O capítulo 3 é reservado à exposição de metodologia: "A Análise Ambiental por Geoprocessamento", pela qual se apresenta a estrutura conceitual e lógica, estritamente bem definida e organizada do Geoprocessamento. Neste capítulo também são citados alguns estudos de caso de aplicação da referida metodologia. Em seguida apresenta, sob a forma de organogramas, a Árvore de Decisão: "Transposições para Áreas de Riscos", assim como as árvores de níveis intermediários: "Riscos de Enchentes - RE", "Riscos de Deslizamentos e Desmoronamentos - RDD", "Áreas Indicadas para Transposições", "Qualidade de Vida (Assentamentos Precários)" e "Áreas Críticas". Estes diagramas definem, de 
forma estruturada, os passos das avaliações para as análises ambientais projetadas. Apresenta definições de indicadores, índices de desenvolvimento humano e qualidade de vida, além dos procedimentos estatísticos para a definição do número de classes, baseado no modelo de Sturges, utilizado para a classificação de dados sócio-econômicos. São introduzidas também definições, da terminologia censitária, segundo o IBGE, freqüentemente citada no capítulo seguinte, através das variáveis sócio-econômicas estudadas. Justifica, de forma ilustrada, a necessidade do trabalho com dados relativizados (taxas percentuais), normalizados pela quantidade de domicílios particulares permanentes de cada setor censitário, na criação dos mapas sócio-econômicos.

O capítulo 4 é reservado aos materiais e métodos empregados, como a descrição da área objeto de estudo, Bacia do Cabuçu, com sua definição territorial determinada pela linha divisora da Bacia Hidrográfica do Córrego Cabuçu de Baixo, delimitação de suas principais sub-bacias, características e o processo de evolução urbanística desenfreada ocorrido naquela região. Em seguida, refere-se à origem e organização da base de dados física, pela qual apresentam-se os distintos critérios, procedimentos metodológicos e também os diversos e necessários programas computacionais específicos, que foram empregados para a geração da base de dados do mundo físico da região da Bacia do Córrego Cabuçu de Baixo. Apresenta a área de estudo por meio de mapas temáticos. Finalmente, destaca a organização da base de dados sócio-econômica, pelo qual mostra-se a importância da integração dos dados populacionais com os do ambiente físico nas análises ambientais. Destacam-se também as variáveis ambientais empregadas para a determinação de índices de desenvolvimento humano e de qualidade de vida, os setores censitários como unidade territorial e também os procedimentos estatísticos adotados na fase de geração da base de dados sócio-econômica.

O capítulo 5 apresenta o desenvolvimento parcial da Árvore de Decisão referentes às avaliações com os dados populacionais oriundos do Censo 2000, seguindo-se a metodologia proposta no capítulo 3. Apresenta os mapas resultantes de avaliações e as análises relativas às dimensões Infra-estrutura básica do estado e do indivíduo à qualidade de vida, condições sociais e herança cultural e condições de renda, mapeando assim a qualidade de vida da região e o mapeamento indicativo de áreas viáveis (e inviáveis) para transposições de assentamentos, baseado nas características físicas da região. Também são apresentados neste capítulo os 
resultados das avaliações ambientais para assentamentos localizados sob áreas de riscos de enchentes, deslizamentos e desmoronamentos, apontando também, por meio de análises geotopológicas, áreas indicadas para transposições destes assentamentos sob mais elevados riscos. Assinaturas espaciais também são realizadas a fim de quantificar as áreas de riscos mapeadas.

No capítulo 6 são processadas as tarefas de verificações para a validação da metodologia proposta. Para tanto são realizadas transposições dos mapas finais, de riscos e áreas críticas sobre imagens Ikonos, além do cotejamento com o mapeamento do histórico de ocorrência de enchentes, deslizamentos e desmoronamentos na região, a fim de constatar a conformidade dos mapeamentos obtidos por meio da metodologia, com a realidade local.

O capítulo 7 destina-se às conclusões, pelas quais se apresentam sinteticamente os resultados alcançados com a pesquisa.

O capítulo 8 reserva-se ao material de referência bibliográfica, consultado durante as fases de desenvolvimento desta pesquisa, que versam sobre os temas Geografia física, Geografia humana, Cartografia, Meio ambiente e gestão da natureza, Indicadores de desenvolvimento, Metodologia científica, Cidade de São Paulo e Geoprocessamento. 


\section{FUNDAMENTAÇÃO TEÓRICA}

\subsection{Relação entre Perigo, Risco e Desastre}

Atualmente, tanto nas publicações especializadas quanto na mídia em geral, há muita confusão terminológica em relação à temática de desastres naturais. Assim, visando padronizar termos e conceitos, buscou-se uma conceitualização simplificada que, ao mesmo tempo, obedece-se aos padrões internacionais e fossem tecnicamente aceitas pela comunidade científica. Dentre as propostas analisadas, foi adotada a base conceitual publicada pela Organização das Nações Unidas (ONU), através dos programas United Nations Development Programme (UNDP) e International Strategy for Disaster Reduction (ISDR), intituladas: Living with Risk. A global review of disaster reduction initiatives (ISDR, 2004) e Reducing Disaster Risk: a Challenge for Development (UNDP, 2004).

\subsubsection{Perigo e desastre}

Com respeito às relações existentes entre perigo e desastre, TOBIN e MONTZ (1997) definem perigo como uma situação potencialmente prejudicial, enquanto que, desastre é a materialização do perigo (Figura 2.1).

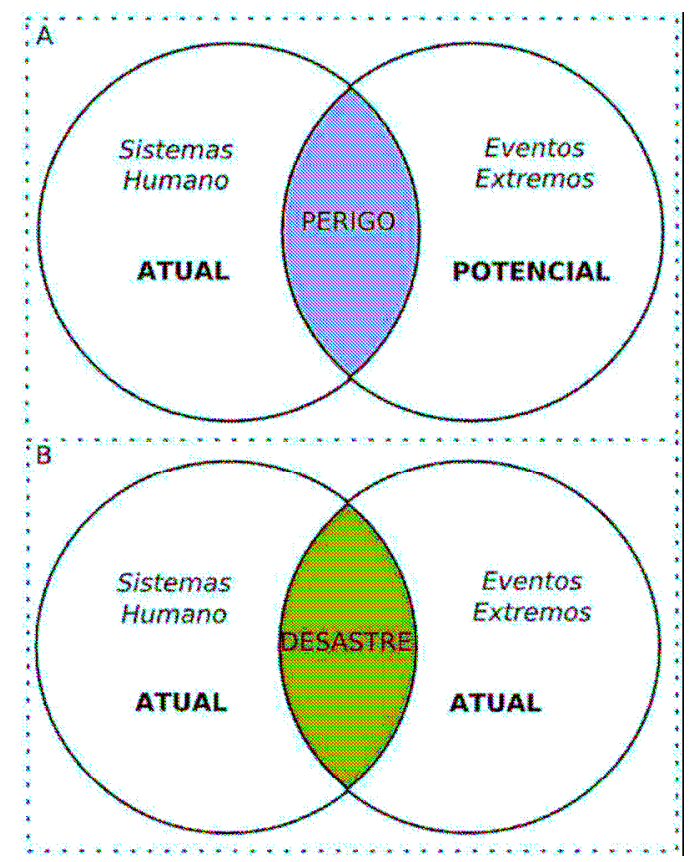

Figura 2.1 - Relação entre perigo e desastre. Adaptado de Tobin e Montz (1997)

Essa relação pode ser melhor assimilada através do esquema proposto na Figura 2.2. Na natureza ocorrem diversos tipos de fenômenos que fazem parte da 
própria dinâmica natural da Terra. Mas, se ocorrerem ou se deslocarem sobre um sistema social, tem-se uma situação potencial de danos a pessoas e bens (perigo).

Caso o impacto produza danos e prejuízos extensivos e/ou de difícil superação pelas comunidades afetadas será então considerado como um desastre. Se as conseqüências forem mínimas ou nulas será considerado somente como um evento natural. Para exemplificar, uma tempestade severa (evento natural) produz fortes chuvas e ventos. Quando se desloca em direção a uma área urbana, densamente ocupada, torna-se um perigo, principalmente para as áreas consideradas de alto risco. Atingindo estas áreas, casas são alagadas e destruídas, pessoas morrem e outras tantas são obrigadas a procurar locais seguros, como os abrigos temporários.

Dependendo da magnitude ou intensidade, os danos podem acarretar num desequilíbrio dos serviços essenciais vinculados ao fornecimento de água, luz, comunicação e transporte, caracterizando num cenário típico de desastre. Entretanto, na continuação da trajetória, quando atinge áreas não-ocupadas (campos e matas), a tempestade volta a ser considerada como um evento natural.

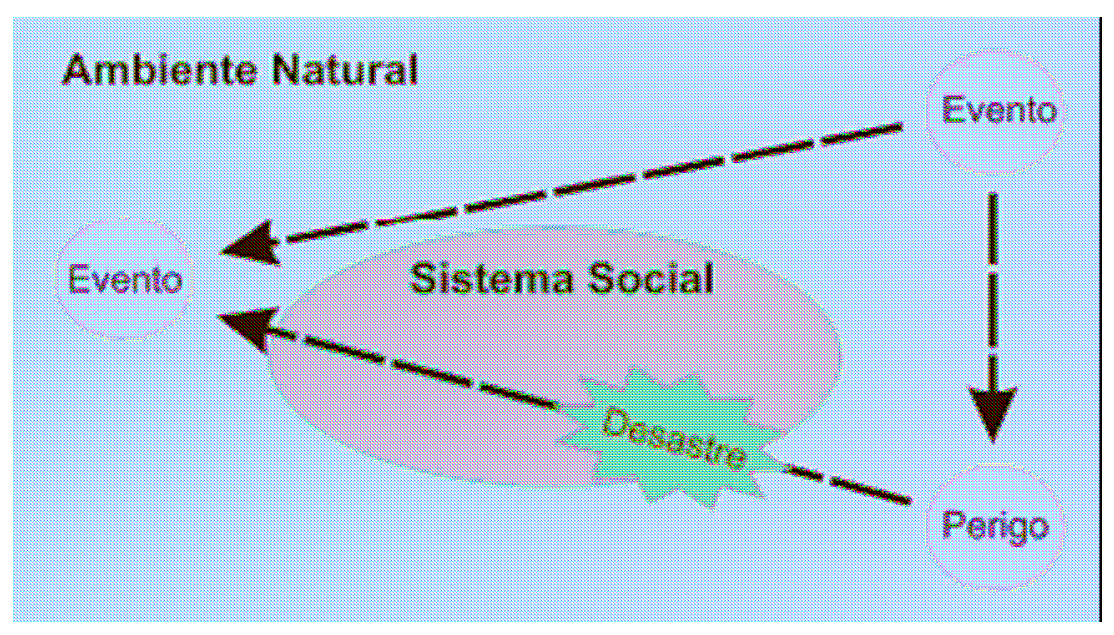

Figura 2.2 - Relação entre evento e desastres de origem natural (MARCELINO, 2007)

\subsubsection{Perigo e risco}

O perigo é muitas vezes associado erroneamente com o risco. Risco é a probabilidade de ocorrer conseqüências danosas ou perdas esperadas (mortos, feridos, edificações destruídas e danificadas, etc.), como resultado de interações entre um perigo natural e as condições de vulnerabilidade local (UNDP, 2004). De forma simplificada, risco é a probabilidade (mensurável) de um perigo transformar-se num desastre. No entanto, a gravidade dos desastres também pode estar vinculada aos elementos sociais expostos, ou seja, a fragilidade do ambiente socialmente 
construído (vulnerabilidade). Analisando a Figura 2.3, pode-se observar que aumentando a freqüência do perigo e a intensidade da vulnerabilidade, aumentará conseqüentemente o risco de um perigo transformar-se num desastre.

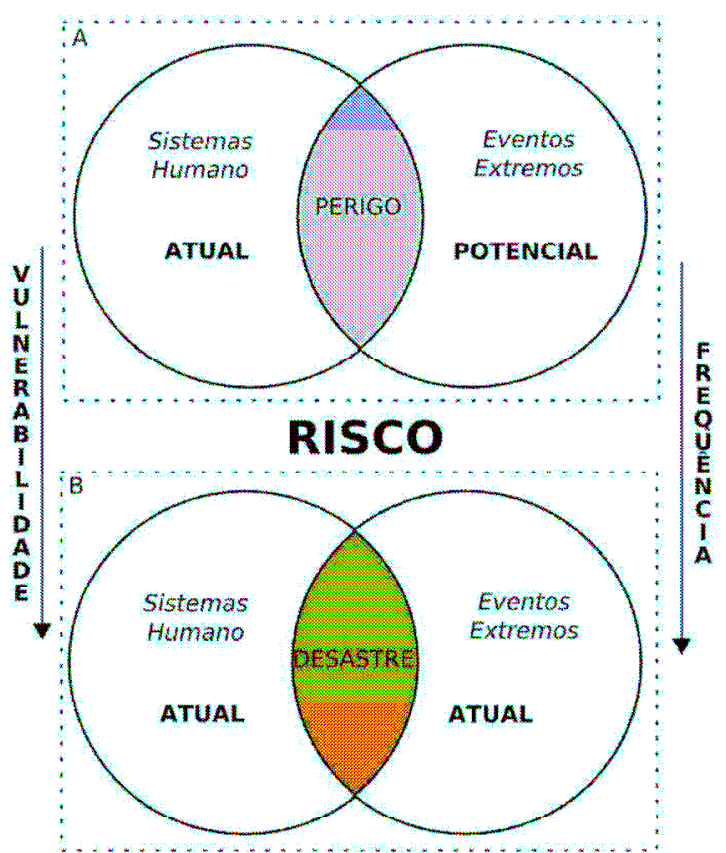

Figura 2.3 - Relação entre perigo e risco. Adaptado de Tobin e Montz (1997) 


\subsection{Modelagem de Dados Espaciais}

Naturalmente, não existe um modo único de interpretar e descrever a realidade. Em particular, a realidade geográfica possui um grande número de características e não é viável representá-las num mesmo sistema de informação. Aliás, qualquer sistema tem apenas capacidade para representar uma dada visão da realidade. Assim, o conjunto de informações de um sistema representa apenas uma descrição parcial da realidade, determinada fundamentalmente tendo em atenção os objetivos a atingir por esse mesmo sistema. Porém, é possível descrever de um modo muito geral os diversos tipos de características da informação geográfica.

Desta forma, a arte de modelagem consiste em decompor o mundo real em uma série de sistemas simplificados para alcançar uma visão sobre as características essenciais de um certo domínio. A representação de modelos pode ser realizada através de vários tipos de linguagem, quer seja matemática, lógica, gráfica ou física. Nesse processo, passa-se por diversos níveis de abstração, no qual a realidade é traduzida para uma série de modelos, até que sua solução possa ser implementada, utilizando o potencial analítico do Sistema de Informações Geográficas (SOARES FILHO, 2000).

\subsubsection{Mundo Real x Modelo Abstrato}

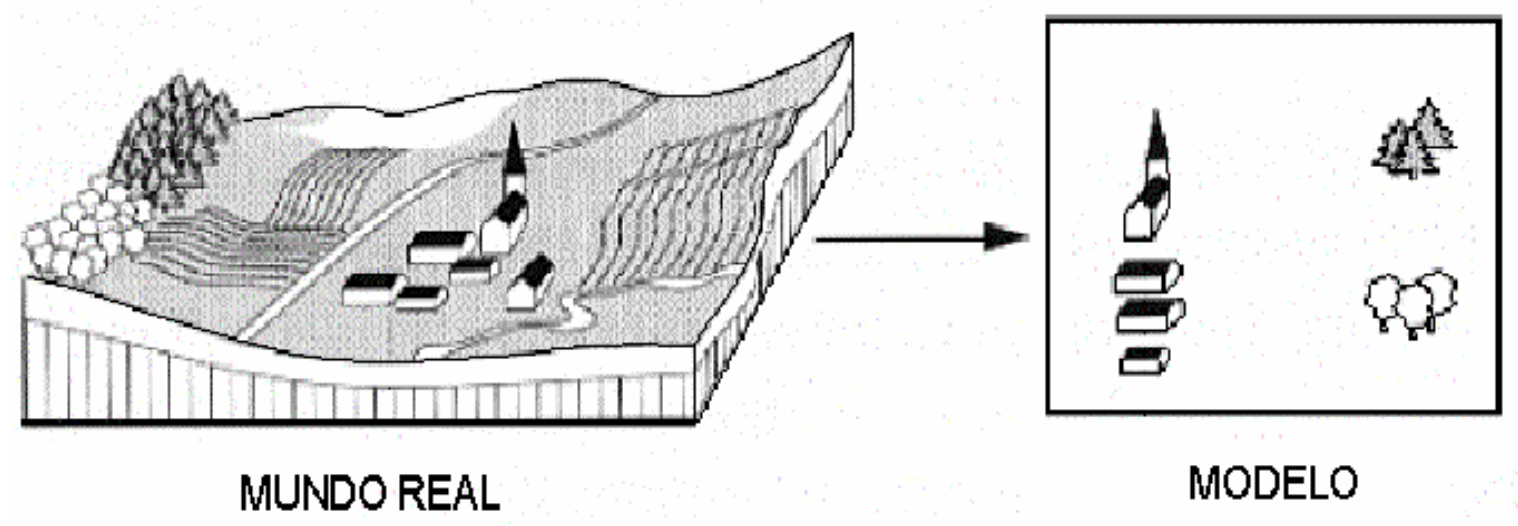

Figura 2.4 - Abstração do mundo real (RODRIGUES, 2004)

De acordo com Rumbaugh, 1994 apud THOMÉ (1998), "abstração é uma capacidade de visão de alto nível que nos permite examinar problemas de forma a selecionar grupos comuns, encontrar generalidades, para melhor compreender 0 problema e construir modelos". A abstração deve estar associada a um propósito. 
Desta forma, pode-se ter várias abstrações de um mesmo problema para propósitos diferentes. A construção de modelos pela abstração possui o caráter de simplificação da realidade a ser modelada, por isso não deve procurar a verdade absoluta, mas sim a adequação ao propósito.

De acordo com RODRIGUES (1994), um modelo é a abstração de algo, com o propósito de permitir que se conheça isso antes de construí-la. A abstração é uma capacidade humana fundamental que nos permite lidar com coisas complexas. Por exemplo, os engenheiros, artistas e artesãos vêm construindo modelos há muito tempo para testar projetos antes de executá-los. A responsabilidade da abstração é definida por uma pessoa, grupos de pessoas, organizações que desenvolvem dados espaciais ou usuários de SIG, também chamados de observador. O grupo de características usadas para representar uma entidade é subjetivamente escolhido. Aquilo que é essencial para descrever uma floresta para um lenhador, por exemplo, pode ser diferente daquilo que é essencial para outras, como, por exemplo, um grupo ambientalista. O modelo abstrato é composto por entidades ou entes (tudo aquilo que existe do mundo real e é importante para a aplicação) e relacionamentos (relações do sistema a ser modelado). Os relacionamentos são apresentados em esquemas de notações gráficas que servem para visualizar o modelo abstraído.

Para RODRIGUES, a abstração de conceitos e entes existentes no mundo real é parte importante do SIG. Tão importante que o sucesso da implementação de um sistema informatizado é diretamente dependente da qualidade do trabalho de modelagem. Se os conceitos forem excessivamente simplificados, corre-se o risco de deixar de lado algum aspecto importante da realidade, com conseqüências sobre as aplicações. Se, por um lado, as representações se tornarem complexas demais, corre-se o risco de gerar sistemas lentos, sobrecarregados, difíceis de manter.

\subsubsection{Modelo de Dados}

Uma primeira abstração do mundo real, baseada no modo como este é tratado, pode conduzir à identificação de dois tipos de perspectivas: uma visão do espaço como sendo composto por campos ou povoado por objetos (COUCLELIS, 1992). Na primeira perspectiva, o espaço é considerado contínuo (visão de campos)

e a observação é feita (teoricamente) sobre todos os locais; na segunda, são selecionados os objetos de interesse, sendo ignoradas as porções do espaço que não contêm entes relevantes, possibilitando dizer-se que, neste caso, o espaço é 
considerado discreto (visão de objetos). De modo informal, pode se dizer que na forma contínua (visão de campos) é observado o que ocorre em todos os lugares, enquanto na forma discreta (visão de objetos) é observado onde ocorrem todas as coisas (TOMLIN, 1991).

Dados contínuos são especialmente adequados à interpretação da realidade geográfica natural, como cobertura do solo, tipos de solo, relevo, cursos de água ou fatores climáticos, a qual é caracterizada por uma distribuição espacial difusa, isto é, sem contornos rígidos.

A observação das características deste tipo de fenômeno em todos os locais do espaço deve conduzir a uma representação mais fiel da realidade do que a sua representação discreta, ao qual são atribuídas características homogêneas e para os quais se tenta fixar um determinado contorno. Por outro lado, a interpretação de objetos cuja existência resulta de intervenção humana, como estradas, edifícios ou fronteiras territoriais, possuindo uma localização geográfica mais definida, adapta-se melhor à forma discreta (visão de objetos). Como exemplo de entes discretos, podemos citar propriedades, vias urbanas, postes; e como exemplo de contínuos o tipo de relevo, o tipo de solo, teor de substâncias químicas, temperatura do ar, etc.

Finalmente, a aproximação do mundo real é feita através do agrupamento dos entes em grupos de camadas (figura abaixo), via de regra, organizadas em mapas. Em cada camada são organizados dados espaciais e atributos para um certo grupo de objetos cartográficos, numa região de interesse. Estas são freqüentemente chamadas de camadas temáticas.

A Figura 2.5 ilustra uma representação espacial do mundo real, em forma de camadas, que inclui uso do solo, parcelamento do solo, ruas e estradas. A camada viária contém somente dados viários incluindo localização e características das vias na área analisada. Não existem dados acerca da localização de qualquer outra entidade geográfica na camada viária. Informações de solo, distritos, hidrografia, etc, estão contidas em suas respectivas camadas (ESRI, 1990).

Através de análises podemos combinar dados para criar uma nova camada. Exemplo: podemos identificar áreas que possuem alta elevação e sobrepor com dados de solos. Esta sobreposição cria uma nova camada com uma nova variável de mapa, elevação / solo. 


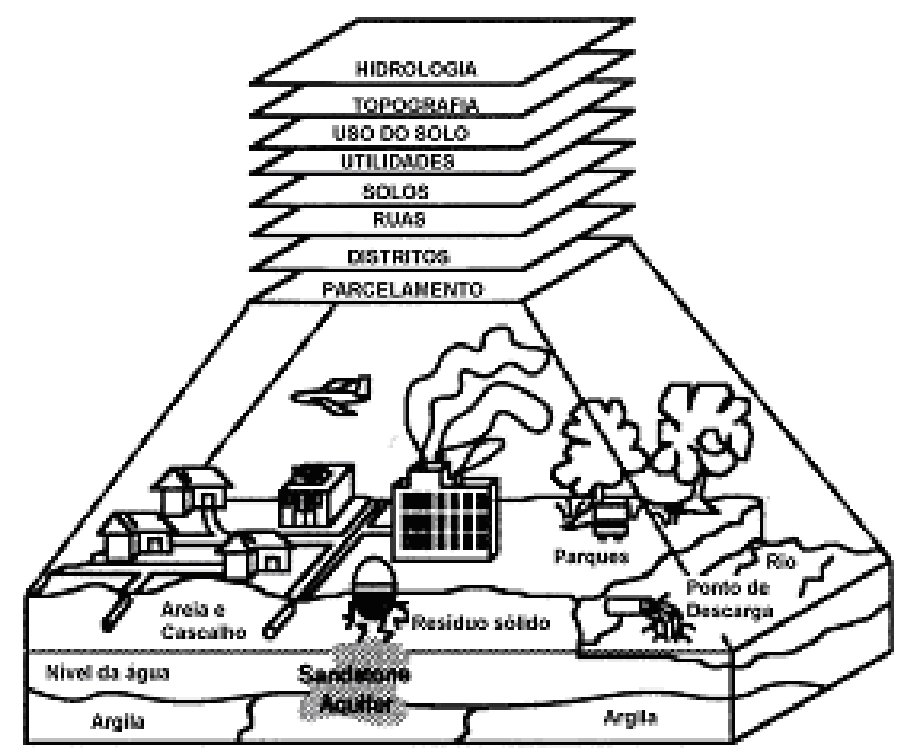

Figura 2.5 - Representação do mundo real em forma de camadas (ESRI, 1990)

Normalmente, um objeto espacial possui simultaneamente três tipos de características: espaciais, para identificação do local onde se situam, não-espaciais, para descrição das suas propriedades e temporais para a sua localização no tempo.

Os mapas, por sua vez, podem ser vistos, como modelos de representação, onde as feições do mundo real são representadas por uma linguagem simbólica do tipo gráfica, e os símbolos referem-se a porções do território.

Esta última abordagem mostra uma evolução da visão tradicional da cartografia, quando o mapa deixa de ser simplesmente um veículo de informação visual, para também ser um instrumento de complexas análises de relacionamentos espaciais (RODRIGUES, 2004). 


\subsection{Sistemas de Informações Geográficas na Gestão Territorial}

A coleta de informações sobre a distribuição geográfica de recursos minerais, propriedades animais e planta sempre foi uma parte importante das atividades das sociedades. Até recentemente, no entanto, isto era feito em documentos e mapas em papel, impedindo uma análise que combinasse diversos mapas e dados. Com o desenvolvimento da tecnologia de informática, tornou-se possível armazenar e representar tais informações em ambiente computacional, abrindo espaço para o aparecimento do Geoprocessamento (CÂMARA, DAVIS E MONTEIRO, 2001).

Nesse contexto, o termo Geoprocessamento denota o conjunto de tecnologias de coleta, tratamento e desenvolvimento de informações espaciais.

Dentre estas tecnologias, o SIG (Sistema de Informações Geográficas) é o conjunto de instrumentos computacionais que processam dados de natureza espacial (exemplos: os CEPs, os números de telefone, os bairros, os municípios, banco de dados, mapas, etc.), permitindo a realização de análises complexas ao integrar dados de diversas fontes e ao criar bancos de dados georreferenciados. Torna possível, ainda, automatizar a produção de documentos cartográficos. Em resumo, os SIGs são sistemas voltados à aquisição, análise, armazenamento, manipulação e apresentação de informações espaciais. 


\section{METODOLOGIA}

\subsection{Organização Metodológica}

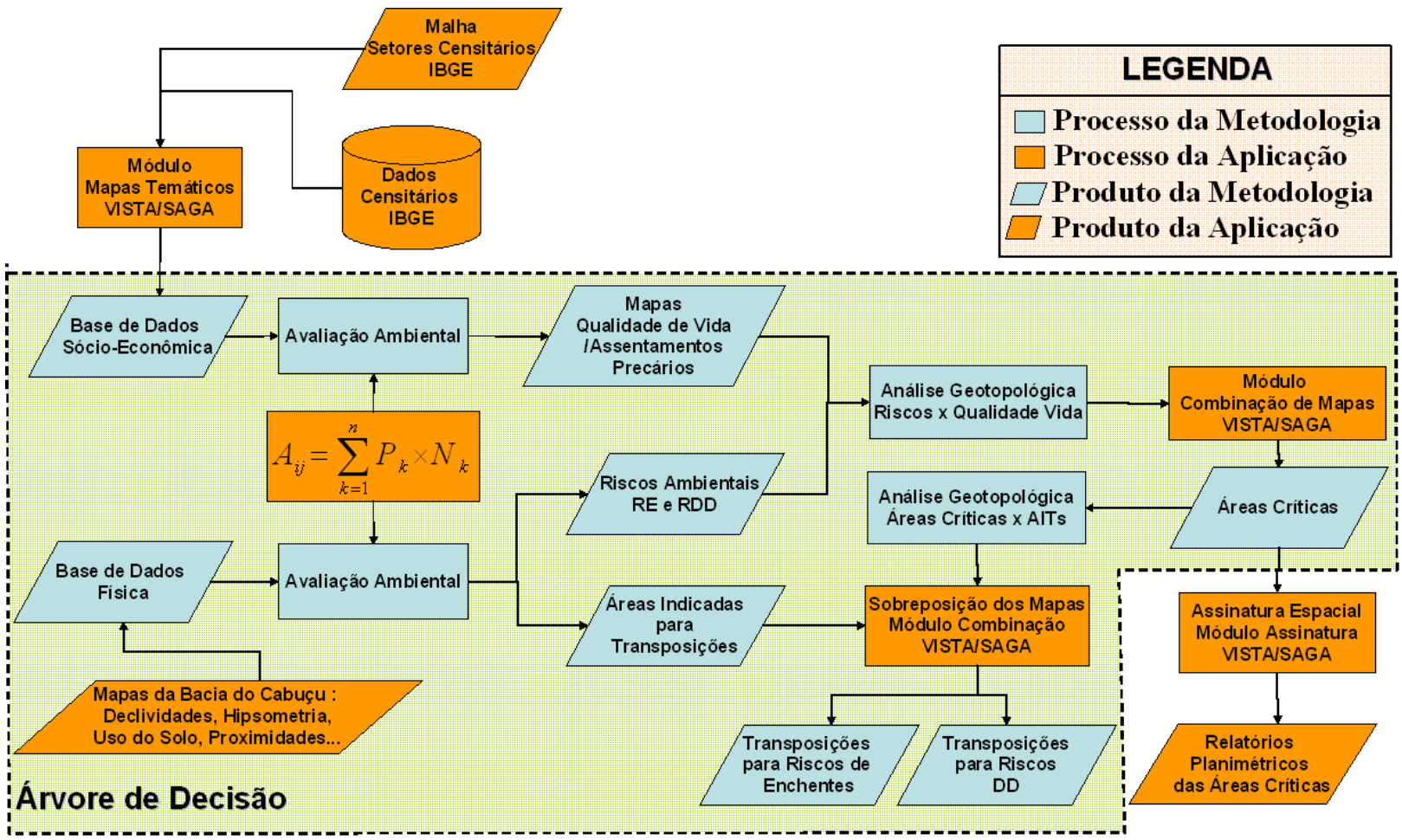

Figura 3.1 - Organização metodológica do trabalho

A Figura 3.1 ilustra os materiais e processos aplicados no trabalho. As caixas foram coloridas de modo a diferenciar os processos (retângulos) e produtos (paralelogramos) específicos da metodologia apresentada (azul) da aplicação específica para a Bacia do Cabuçu (laranja).

Todo o processo é modelado numa estrutura de representação denominada "Árvore de Decisão", que apresenta, passo a passo, cada avaliação intermediária necessária a se chegar ao resultado final ("Transposições Indicadas para Riscos"). A estrutura é apresentada de forma detalhada em 3.3.

Constituem os procedimentos metodológicos:

\section{- Base de Dados Sócio-Econômica}

No estrato superior do fluxograma apresentam-se a malha e dados censitários, obtidos a partir do IBGE. Constituem os elementos necessários para a geração de mapas temáticos que compõem a base de dados sócio-econômica do estudo. $\mathrm{O}$ processo é viabilizado, para esta particular aplicação, por meio da utilização do "Módulo de Criação de Mapas Temáticos", componente do aplicativo VISTA/SAGA. 
A coloração laranja destas caixas se justificada devido à possibilidade da base de dados sócio-econômica ser obtida a partir de qualquer outra fonte (ou até mesmo gerada) e também processada por outros aplicativos, de acordo com os conhecimentos do analista e disponibilidade de dados para a localidade de estudo. Além da flexibilidade quanto à fonte dos dados, fica a critério do analista a seleção das variáveis sócio-econômicas a serem utilizadas na avaliação de qualidade de vida. Para esta aplicação a unidade territorial adotada são os setores censitários, definidos a partir de IBGE (2002), detalhada no item 4.3.1 e a seleção das variáveis sócio-econômicas são apresentadas e justificadas no item 3.7.1.

\section{- Base de Dados Física}

Trata-se do conjunto de mapeamentos físicos da região de estudos. Selecionados a critério do avaliador, compõem os fatores físicos que influenciam diretamente, em sua concepção, na ocorrência dos riscos ambientais analisados. Para a aplicação na Bacia do Cabuçu foram definidos os mapas de Uso do Solo e Cobertura Vegetal, Declividades, Altimetria, Proximidades Viária e da Rede de Drenagem, Geomorfologia e Geologia.

\section{- Avaliação Ambiental}

A partir das bases de dados sócio-econômica (Renda, Analfabetismo, Coleta de Lixo, etc.) e física (Uso do Solo, Altimetria, Declividade, Proximidades, Geomorfologia, etc.) aplica-se formulação da Avaliação Ambiental (detalhada em 3.2.3) para obtenção dos mapas de "Qualidade de Vida/Assentamentos Precários", "Riscos Ambientais" (Riscos de Enchentes - RE e Riscos de Deslizamentos e Desmoronamentos - RDD) e "Áreas Indicadas para Transposições" (AITs). A escolha do algoritmo avaliativo para o processamento das análises também é flexível a outras formulações e aplicativos, a critério do avaliador.

\section{- Análises Geotopológicas}

Segundo XAVIER e ZAIDAN (2007, p. 20), "O Geoprocessamento tornou possível, em uma escala inimaginada, analisar a Geotopologia de um ambiente, ou seja, investigar sistematicamente as propriedades e relações posicionais dos eventos e entidades representados em uma base de dados georreferenciados, transformando dados em informação destinada ao apoio à decisão". 
A identificação de "Áreas Críticas" (Mapa 24 e Mapa 25) é produto de uma Análise Geotopológica, uma vez que a sobreposição (overlay) do mapa de "Qualidade de Vida" aos "Riscos Ambientais", processada no módulo "Combinação de Mapas" do VISTA/SAGA, resultará na combinação de todas as entidades (classes) do primeiro com o segundo mapa. O resultado viabiliza a identificação de ocorrências de incidências conjuntas de duas classes quaisquer de interesse para o estudo.

Portanto, o termo é utilizado para definir o ganho de conhecimento oriundo do resultado desta operação, uma vez que serão mapeadas as localidades cuja baixa qualidade de vida incida em áreas de alto risco, ou seja, as áreas críticas. A ocorrência conjunta entre áreas de alto risco e baixa qualidade de vida constitui uma relação geotopológica entre as duas classes combinadas, no mapa resultante.

Relatórios planimétricos são realizados, através do módulo "Assinatura Ambiental", do VISTA/SAGA, a fim de quantificar espacialmente as áreas críticas. Trata-se de um procedimento aplicado especificamente para a região mas pode ser utilizada em quaisquer outras aplicações desta metodologia. Este processo recebe a coloração laranja por este não constituir um fator imprescindível ao prosseguimento da metodologia.

Finalmente, os mapas de "Áreas Indicadas para Transposições" são combinados com os mapas de "Áreas Críticas" e, novamente, através da análise geotopológica são identificadas áreas indicadas para transposições para riscos de enchentes e riscos de deslizamentos e desmoronamentos (estrato inferior da Figura 3.1). 


\subsection{A Análise Ambiental por Geoprocessamento}

Questões ambientais de todas as naturezas, origens e níveis têm sido observadas ao longo do tempo, e os impactos das ações humanas e dos fenômenos naturais vêm sendo estudados, e pública e freqüentemente discutidos e divulgados, especialmente nos últimos trinta anos.

A metodologia de Geoprocessamento a ser adotada é a elaborada conforme XAVIER DA SILVA e CARVALHO (1993) e XAVIER DA SILVA (2001), para os quais as ocorrências desses problemas de impacto ao meio ambiente saudável são comuns, dentro de dimensões básicas do mundo físico, por isso apresentam dimensão territorial e ocorrem segundo um processo dinâmico, como função tempo. Com base em informações de séries temporais dos registros das ocorrências desses fenômenos ambientais, pode-se aprender o comportamento de sua evolução e elaborar previsões sobre prováveis ocorrências futuras.

Para compreender bem o fenômeno, o homem, em seu processo de constante evolução, elabora metodologias e procedimentos para o seu aprendizado. Dessa forma, desenvolve processo de levantamento de todos os aspectos para ter conhecimento da situação atual, o que possibilita suporte ao seu diagnóstico. Com base nesse diagnóstico, pelo qual se tem a identificação e forma da ocorrência dos fenômenos que atuam sobre $\mathrm{o}$ ambiente em estudo, pode-se proceder ao prognóstico, pelo qual se faz sugestões para se modificar as condições de uso dos recursos, e faz-se também previsões para os casos de haverem sido, ou não, tomadas pelo administrador as providências quanto às medidas mitigadoras e compensatórias XAVIER DA SILVA (2001).

\subsubsection{O Projeto SAGA/UFRJ}

O Sistema de Análise Geo-Ambiental - SAGA/UFRJ foi implantado em 1983 no Departamento de Geografia da UFRJ, pelo Prof. Dr. Jorge Xavier da Silva, coordenador do então Grupo de Pesquisas em Geoprocessamento (GPG). Foi desenvolvido como um sistema para aplicações ambientais de fácil implantação e utilização em equipamentos de baixo custo, o que se tornou possível, principalmente, graças ao crescimento da popularidade e uso de microcomputadores do tipo IBM-PC.

Estimativas de riscos de desmoronamentos e de enchentes, potenciais turístico e de urbanização, levantamento e diagnóstico de remanescentes da Mata 
Atlântica no Espírito Santo, para fins de preservação, e a análise da qualidade de vida em favelas, constituem uma pequena amostra das pesquisas realizadas pela comunidade de usuários, através da utilização do Sistema de Análise Geo-Ambiental - SAGA/UFRJ.

Sua primeira versão foi criada na década de 80 , apresentando mapas com, no máximo, 16 cores. Nesta época o geoprocessamento era bastante limitado pela barreira tecnológica.

Seguindo a evolução da informática, o Vista Saga também foi evoluindo com novas versões mais sofisticadas, trabalhando com mais cores e maior rapidez no processamento das análises. Hoje, o Vista Saga trabalha com cores de 32 bits, viabilizando até a visualização em três dimensões de áreas de estudos.

Além disso, é importante ressaltar que o VISTA/SAGA já apoiou mais de uma centena de teses de mestrado e doutorado. É um projeto $100 \%$ nacional, desenvolvido em meio acadêmico e, sem fins lucrativos. Pode ser obtido gratuitamente através do site www.lageop.ufrj.br (MARINO, 2005).

Constituem seus principais módulos de processamento:

- MONITORIA - Proporciona o acompanhamento de alterações ambientais significativas de diversas naturezas, permitindo a identificação de agentes modificadores do ambiente, apoiando a previsão de modificações futuras e possibilitando a proposição de eventuais soluções para os problemas ambientais - ESTUDO TEMPORAL DA ÁREA. Ex.: "O que era Mata Nativa em Cabo Frio em 1978 e, hoje são áreas urbanas, e/ou favelas? O que continuou a ser...?'

- ASSINATURA - Permite identificar a ocorrência conjunta de variáveis, através de planimetrias dirigidas - ESTUDO TERRITORIAL DA ÁREA.

- AVALIAÇÃO - Utilizado para realizar estimativas sobre possíveis ocorrências de fenômenos, de diversas naturezas, segundo diversas intensidades, definindo-se a extensão territorial destas estimativas e suas relações de proximidade e conexão. Este módulo gera um mapa do território analisado, classificando cada local com notas de 0 a 10. Ex.: Risco de propagação de doenças, Potencial turístico, Risco de Enchente, Transitabilidade, etc.. 


\subsubsection{A Escolha do SAGA/UFRJ}

Como o próprio nome já diz, SAGA - Sistema de Análise Geo-Ambiental, trata-se de uma ferramenta específica para o processamento das avaliações ambientais. Outro fator essencial é a possibilidade de acesso ao código fonte do programa, viabilizando a criação das rotinas complementares, necessárias ao prosseguimento do trabalho $\mathrm{e}$, conseqüentemente, enriquecimento do poder operacional do aplicativo. As rotinas criadas ao longo do projeto estão delineadas no item 3.6 - "Desenvolvimento de Rotinas para o VISTA/SAGA".

Contudo, nada impede que os mesmos procedimentos sejam aplicados em qualquer outro software que disponha de recursos que viabilizem a aplicação metodológica proposta. O cerne deste trabalho constitui-se na apresentação da metodologia para tomadas de decisão no âmbito de riscos sócio-ambientais de áreas urbanas. O VISTA/SAGA foi apenas escolhido como ferramenta de aplicação em função de sua praticidade e profundo conhecimento na utilização do aplicativo se alcançar a finalidade proposta.

\subsubsection{Formulação da Análise Ambiental}

A formulação de média ponderada é proposta nas avaliações ambientais, integrante do sistema SAGA, conforme a seguir exposta:

$$
A_{i j}=\sum_{k=1}^{n} P_{k} \times N_{k}
$$

onde,

$\mathbf{n} \rightarrow$ Número de parâmetros (mapas) utilizados;

$\mathbf{A}_{\mathrm{i}, \mathrm{j}} \rightarrow$ Probabilidade de ocorrência do evento analisado no elemento (pixel) i,j da matriz (mapa) resultante;

$\mathbf{P}_{\mathbf{k}} \rightarrow$ Peso (percentual) da contribuição do parâmetro "k", em relação aos demais, para a ocorrência do evento analisado;

$\mathbf{N}_{\mathbf{k}} \rightarrow$ Nota, segundo o(s) avaliador(es), dentro da escala de "0 a 10", da ocorrência do evento analisado, na presença da classe encontrada na linha i, coluna j do mapa k.

Pixel $\rightarrow$ Aglutinação de Picture e Element, ou seja, elemento de imagem, sendo Pix a abreviatura em inglês para Picture. É o menor elemento num dispositivo de 
exibição (como por exemplo um monitor), ao qual é possível atribuir-se uma cor. De uma forma mais simples, um pixel é o menor ponto que forma uma imagem digital, sendo que o conjunto de milhares de pixels formam a imagem inteira. A Figura 3.2 possui dimensões de $31 \times 15$, ou seja, 31 colunas por 15 linhas, totalizando 465 pixels (adaptado de MARINO, 2005).

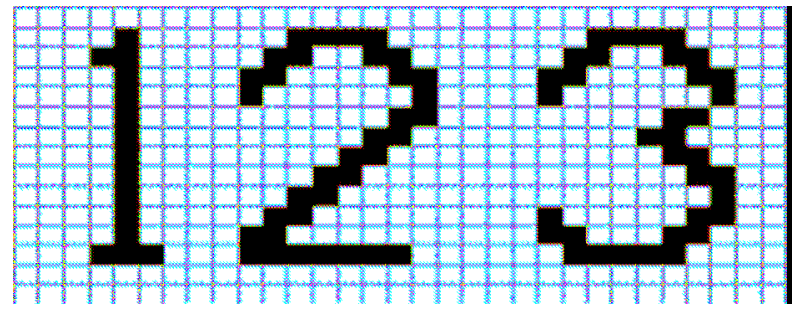

Figura 3.2 - Pixels da imagem (MARINO, 2005)

A partir desta formulação de Análise Ambiental, podem ser feitas as seguintes proposições, também segundo XAVIER DA SILVA (2001):

- $A_{i, j}$ exprime a probabilidade resultante do produto da formulação ambiental, numa escala de 0 a 10 , para a ocorrência de um evento, ou entidade ambiental, que seja causado, em princípio, pela atuação convergente dos parâmetros ambientais nela considerados;

- Os dados envolvidos na avaliação podem ser lançados em uma escala ordinal que varie entre 0 e 10 ou entre 0 e 100, para que seja gerada uma amplitude de variação suficiente a permitir maior percepção da variabilidade das estimativas;

- A normalização dos pesos, restritos entre os valores 0 e 1 , resulta na definição do valor do peso atribuído a um mapa como o valor máximo que qualquer das classes daquele mapa pode assumir. Por exemplo: atribuir um peso de $40 \%$ ao parâmetro "declividades", numa análise, significa que o máximo que uma determinada classe deste mapa pode contribuir na determinação da probabilidade de ocorrência do evento analisado é de 4 , numa escala de 0 a 10.

- Com a adoção da média ponderada está criado um espaço classificatório que é, em princípio, ordinal, mas que pode admitir grande e variado detalhamento na classificação das estimativas.

\subsubsection{Avaliações diretas e complexas}

A Avaliação Ambiental pode ser sub-dividida em avaliações diretas e complexas. 


\subsubsection{Avaliações diretas (ou simples)}

São aquelas que resultam da combinação imediata dos dados originalmente inventariados, isto é, são os primeiros resultados avaliativos obtidos com a combinação dos dados originais. Estas combinações podem gerar alguns tipos de mapeamento, entre os quais merecem destaque os de riscos e de potenciais ambientais. Seguem alguns exemplos de aplicação de avaliação direta.

\section{Riscos ambientais}

O conceito de risco ambiental é, essencialmente, uma ligação da ocupação humana com as possibilidades de ocorrência de eventos que the sejam danosos. Embora o rebatimento sobre a ocupação humana não seja imprescindível - caso da previsão, entre outras, de erupções vulcânicas em áreas desabitadas - é inteiramente dominante a definição de riscos segundo sua importância para o homem. Tem, portanto, uma conotação negativa, a qual se expressa, por exemplo, nos termos "de alto risco" aplicados a uma determinada situação ambiental.

Uma vez adotada uma escala de medição uniformizada, estimativas de riscos de diversos tipos (enchentes, desmoronamentos, ressacas, chuvas de granizo) podem ser conjugadas em um esquema numérico integrador, gerando assim a definição de áreas com diferentes níveis de risco ambiental, o que pode sinalizar quanto a áreas adequadas ou inadequadas para um determinado uso, quanto a áreas de valor intermediário, assim como identificar aquelas áreas onde os riscos são altos ou, pelo contrário, insignificantes. Normalmente estas conjugações são aferidas pelo uso de escalas ordinais, muitas vezes traduzidas por expressões do tipo "alto risco", "riscos intermediários" e "baixos riscos".

\section{Potenciais ambientais}

O termo "potencial ambiental", assim como o anteriormente apresentado "risco ambiental", não é proposto aqui com um caráter definitivo, acabado. Isto também é verdade para todos os termos apresentados neste trabalho. Estes termos representam, antes de mais nada, um esforço de comunicação quanto a conceitos julgados úteis. Note-se que estes conceitos não são apresentados isoladamente, mas sim dentro de uma estrutura de apresentação de um roteiro de raciocínio, enfim, dentro de uma metodologia. 
Segundo a ótica acima apresentada, pode-se entender potencial ambiental como um levantamento de condições ambientais no qual são identificadas a extensão e possível expansão territorial de um processo ambiental. Pode existir uma conotação positiva na avaliação, mas esta não é obrigatória. São exemplos a urbanização desordenada (de teor negativo) ou a urbanização planejada, o potencial turístico de uma região ou a aptidão agrícola de uma determinada área, estes últimos portadores de conotação positiva, em princípio.

A partir da existência de um inventário ambiental de uma área geográfica, sobre o qual tenham sido feitas análises (assinaturas, monitorias e probabilidades de transição, estimativas de riscos e potenciais), é possível levantar todo um conjunto de estimativas, de óbvio interesse direto para o planejamento e a gestão territoriais.

É o caso da avaliação de necessidades de proteção ambiental, na qual podem aparecer como elementos definidores das necessidades mencionadas não apenas os riscos que a situação ambiental apresente, mas também os potenciais nela existentes, que podem definir igualmente necessidades de proteção. Como exemplo pode ser citado o caso das Unidades de Conservação Ambiental (Parques, Reservas, etc.), nos quais podem existir riscos de incêndios associados a queimadas em regiões limítrofes, mas também onde os próprios potenciais turísticos que apresentem as unidades de conservação geram necessidades de proteção, por serem elemento de atração para visitantes autorizados.

\subsubsection{Avaliações complexas}

Em contraste com as chamadas avaliações diretas, feitas sobre os dados originais constantes do inventário ambiental, podem existir avaliações ditas complexas, isto é, que usam uma ou várias avaliações prévias como base para sua construção. Podem se referir ao cotejo de uma avaliação contra um dado básico, ou mesmo reproduzir o resultado do confronto entre as expressões territoriais de avaliações previamente elaboradas. Exemplos destas avaliações complexas são apresentados a seguir.

\section{Incongruências de uso}

Incongruências de uso dos recursos ambientais disponíveis podem ser reveladas pelo confronto dos mapeamentos de uso da terra com mapas avaliativos de um potencial. É o caso do lançamento de um mapa de potencial (ou aptidão) 
agrícola de uma área contra um mapa que mostre o uso atual da terra, nesta mesma área. O levantamento de incongruências eventualmente existentes (terras de alto potencial não sendo usadas, terras de baixo potencial sendo usadas, por exemplos), é um produto imediato deste tratamento. Analogamente podem ser identificadas áreas onde um potencial de urbanização (possível crescimento de favelas, por exemplo) tem possibilidades de concretizar-se às custas de desmatamentos e invasão de áreas protegidas por lei. Deve ser notado que, no último exemplo citado, foi obtida uma capacidade de previsão, indispensável como apoio à decisão quanto a medidas preventivas.

Um caso de avaliação complexa de algum interesse é o lançamento do potencial turístico de uma área contra o uso da terra nela registrado. Decisões de grande valor econômico podem se basear neste confronto de um potencial com um uso atual da terra. Uma avaliação complexa deste tipo corre o risco de tornar-se um roteiro de exploração desenfreada dos recursos turísticos de uma região.

A figura a seguir mostra, diagramaticamente, a identificação de incongruências de uso. Deve ser notado que, na figura mencionada, é retratada uma situação simplificada, com duas instâncias de qualificação do potencial sendo lançadas contra um único uso. Quando aplicado a situações reais, este procedimento de investigação pode revelar diversos níveis de incongruência, segundo os diversos níveis de potencial que sejam considerados, e sua aplicação sucessiva a diferentes usos da terra pode resultar em um mapa de incongruências relativamente complexo. 


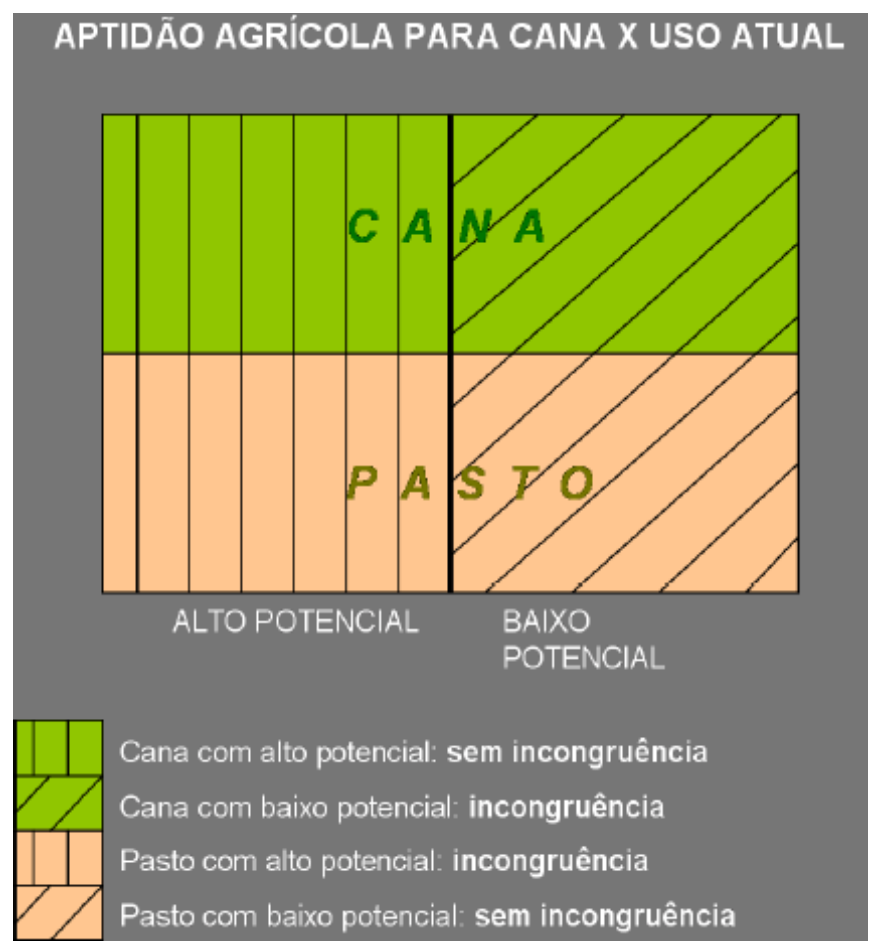

Figura 3.3 - Exemplo de caso de incongruência de uso (XAVIER DA SILVA, 2001)

\section{Potenciais conflitantes}

Conforme indicado pelo próprio sub-título, trata-se, neste caso, do confronto entre mapeamentos avaliativos de potenciais. É esperado que destes cotejos surjam, pelo menos, duas classes de áreas: as conflitantes e as não conflitantes (podendo também ser identificados níveis de conflitos intermediários). A Figura 3.4 mostra, de maneira simplificada, o resultado de uma situação de conflito de potenciais.

Este confronto sinaliza quanto a prejuízos mútuos para os potenciais considerados e pode indicar também o nível destes prejuízos. Da análise deste tipo de mapa de confronto emanam, muitas vezes com clareza meridiana, as necessidades de conciliação dos potenciais ambientais. Decisões de valor econômico e de caráter prospectivo podem surgir deste confronto. $\mathrm{O}$ apoio à decisão quanto à premência e localização de obras de infra-estrutura pode ser gerado da análise destes mapas. As medidas criadas para superação ou minimização dos efeitos destes conflitos de potenciais podem ser denominadas normas de manejo ambiental e as áreas geográficas onde se apliquem podem denominar-se unidades de manejo ambiental. Estas normas e unidades de manejo ambiental, que também podem ser criadas a partir dos outros procedimentos analíticos aqui apresentados, podem ser paulatinamente identificadas ao longo da análise ambiental em 
andamento, vindo a constituir-se nos elementos básicos para a criação organizada de um planejamento ambiental. Neste caso, ter-se-á uma coleção de áreas e normas constatadas ao final da análise empreendida, as quais podem vir a ser cotejadas entre si, priorizadas e integradas no planejamento ambiental.

\begin{tabular}{|c|c|}
\hline $\begin{array}{l}\text { ALTO POTENCLAL } \\
\text { TURISTICO }\end{array}$ & $\begin{array}{l}\text { ALTO POTENCIAL } \\
\text { TURISTICO }\end{array}$ \\
\hline $\begin{array}{l}\text { ALTO POTENCLAL DE } \\
\text { URBANIZAÇÃO }\end{array}$ & $\begin{array}{l}\text { BAIXO POTENCIAL DE } \\
\text { URBANIZACEÃO }\end{array}$ \\
\hline $\begin{array}{l}\text { BALXO POTENCLAL } \\
\text { TURISTICO }\end{array}$ & $\begin{array}{l}\text { BALXO POTENCLAL } \\
\text { TURISTICO }\end{array}$ \\
\hline $\begin{array}{l}\text { ALTO POTENCIAL DE } \\
\text { URBANIZAÇÃO }\end{array}$ & $\begin{array}{l}\text { BALXO POTENCIAL DE } \\
\text { URBANIZAÇÃO }\end{array}$ \\
\hline
\end{tabular}

Figura 3.4 - Exemplo de caso de potenciais conflitantes (XAVIER DA SILVA, 2001)

\section{Áreas críticas}

O confronto entre mapas de uso e estimativas de riscos ambientais permite a definição de áreas com diferentes níveis de ocorrência simultânea de riscos e de usos da terra específicos. A figura abaixo exemplifica uma área crítica quando um local com forte potencial de urbanização se apresenta com riscos de enchentes. Como esses riscos se concretizam episodicamente, é comum que urbanizações desordenadas (favelas) se verifiquem em locais sujeitos a enchentes esporádicas, com os efeitos catastróficos conhecidos (perdas materiais e de vidas humanas de toda ordem e eclosão de epidemias são exemplos).

Outro caso comum nas cidades brasileiras, análogo ao da urbanização em áreas sujeitas a enchentes, é o da ocupação de encostas, por favelas, em áreas com riscos de desmoronamentos e deslizamentos. A definição de áreas críticas quanto ao potencial agrário $x$ riscos de erosão dos solos é um caso em que o caráter crítico do problema pode ficar mascarado pela natureza paulatina do processo de esgotamento dos solos agrícolas. Os efeitos definidos por este confronto entre potencial agrário e riscos de erosão dos solos podem, no entanto, ser estimados antecipadamente. Definidas previamente as áreas críticas, medidas de manejo e proteção do solo agrícola podem ser preconizadas e implementadas. 


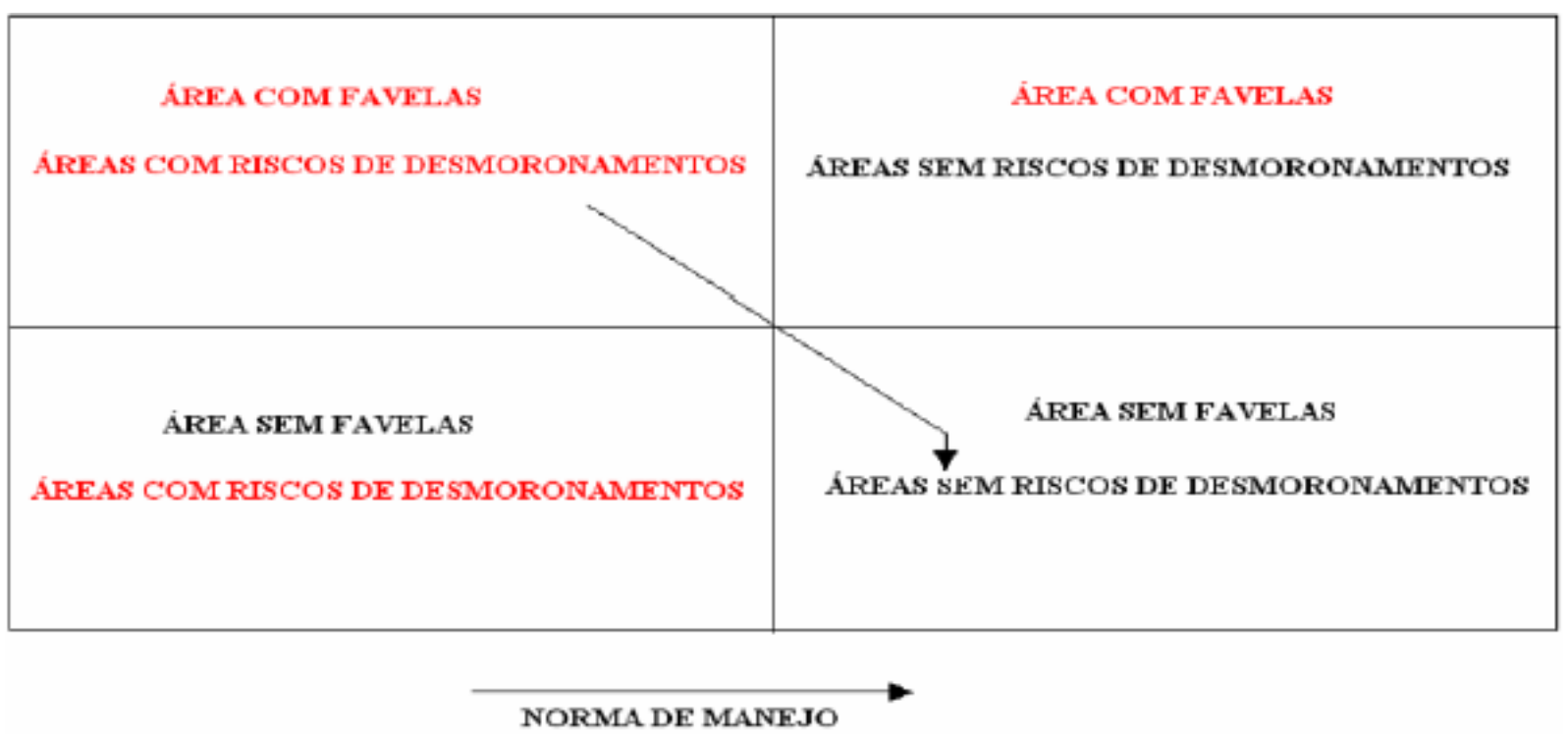

Figura 3.5 - Exemplo de caso de áreas críticas (XAVIER DA SILVA, 2001) 


\section{3. Árvore de Decisão: Transposições para Áreas de Riscos}

A possibilitar a compreensão do encaminhamento dado à investigação concernente à avaliação ambiental da região da bacia do Cabuçu, para fins de síntese com foco na temática da distribuição territorial da qualidade de vida e riscos ambientais na cidade, apresentam-se árvores de decisão, a integral múltipla e as discriminadas conforme os temas distintos, com as quais podem ser visualizados e apreciados os procedimentos, a lógica adotada e os roteiros percorridos para as avaliações ambientais efetuadas, a partir dos componentes ambientais identificados, que foram individualizados na base de dados cartográfica, segundo o processo cartesiano da metodologia científica, pela aplicação do algoritmo de média ponderada em que se estrutura o sistema SAGA, seguindo-se o processo lógico de integração proporcionado pelo Geoprocessamento.

Para se chegar à síntese final de integração, foram elaboradas árvores de decisão distintas, estruturadas em bases da geografia física da região de estudo, e em bases da geografia humana, para as quais se tomou como princípio os componentes ambientais tradicionalmente pesquisados para a criação dos índices que expressam os níveis de desenvolvimento regional e de qualidade de vida.

$\mathrm{Na}$ Figura 3.6 apresenta-se a estrutura completa da múltipla árvore de decisão, na forma da qual foram geradas as análises ambientais. E, nas demais, imediatamente a seguir, expõem-se individualmente as árvores dos temas físicos e das características populacionais que integraram os estudos para a definição da distribuição territorial da qualidade de vida e riscos na região da bacia do Cabuçu.

As árvores de decisão elaboradas que compõem este trabalho são as seguintes:

- Riscos de Enchentes;

- Riscos de Desmoronamentos e Deslizamentos;

- Áreas Indicadas para Transposições;

- Qualidade de Vida (Assentamentos Precários);

- Áreas Críticas para RE /RDD;

- Transposições Possíveis para Riscos. 


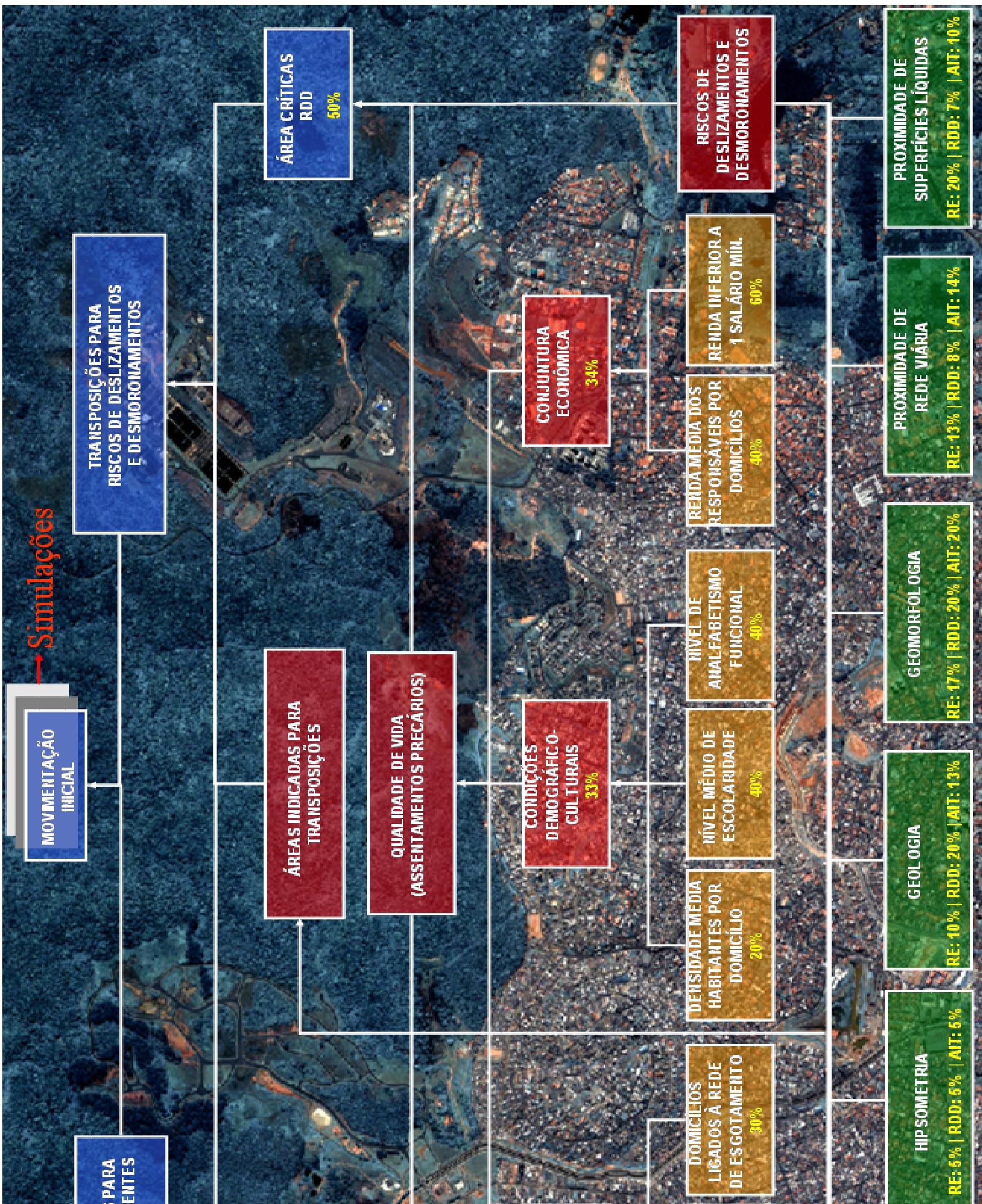


O diagrama acima é denominado "Árvore de Decisão", uma vez que propicia, em seus diversos níveis, apoio a decisões quanto ao seu objetivo formal, ou seja, estimar a quantidade, a localização e a extensão dos movimentos populacionais a serem executados em uma área, tendo em vista a melhoria da qualidade de vida de seus habitantes. Cada um dos retângulos representa um mapeamento digital de um parâmetro de análise ou uma avaliação ambiental que tenha sido executada.

A inspeção desta árvore de decisão, como também das parciais seguintes, possibilita que se apresentem constatações relevantes quanto à origem dos dados:

- No estrato inferior da figura (nós folhas da árvore) constam os mapas básicos elaborados e que constituem os componentes ambientais decisivos para as análises que se vão empreender, e que são resultantes de levantamentos e de interpretações da realidade ambiental da Bacia do Cabuçu.

- Os mapas da geografia física, utilizados nos ramos de riscos de enchentes e deslizamentos, foram elaborados por meio de estudos realizados no projeto "Cabuçu de Baixo" (BARROS, 2004). A partir destes foram realizados procedimentos de conversões dos mapas digitais, em formato SHP para o formato Raster/SAGA.

- Os mapas da realidade ambiental sob a perspectiva da geografia humana, utilizados nos ramos infra-esturura, condições sociais e condições de renda foram gerados a partir dos dados censitários produzidos por IBGE (2000), referentes à Base de Informações por Setor Censitário - Censo demográfico 2000.

- Os mapas derivados e resultantes de análises mostram-se de forma assimétrica no modelo, e foram elaborados no ambiente do programa VISTA/SAGA.

- A estimativa de mais alto nível foi obtida a partir da conjugação e integração das Condições Físico-Ambientais com a representação cartográfica das Condições de Renda, e constitui, para o elevado nível de detalhe possibilitado pela escala e resolução adotadas, a distribuição territorial de locais indicados para transposições de assentamentos precários.

- Deve-se esclarecer que as escolhas dos parâmetros (mapas) envolvidos bem como atribuições de pesos e notas para as avaliações realizadas neste trabalho foram realizadas de acordo com a opinião do pesquisador deste projeto, que não detém todos os conhecimentos suficientes para uma análise 
deste nível de complexidade. Vale lembrar que este é um processo extremamente interativo e interdisciplinar, devendo contar com técnicos especializados nos temas em discussão a fim de se obter valores mais próximos da realidade. Neste caso o objetivo principal é de apresentar a metodologia de localização de áreas sob riscos ambientais.

As seções a seguir caracterizam as árvores de decisão individualizadas, relativas aos temas físicos e aos das características populacionais que integraram os estudos.

\subsubsection{Riscos de Enchentes - RE}

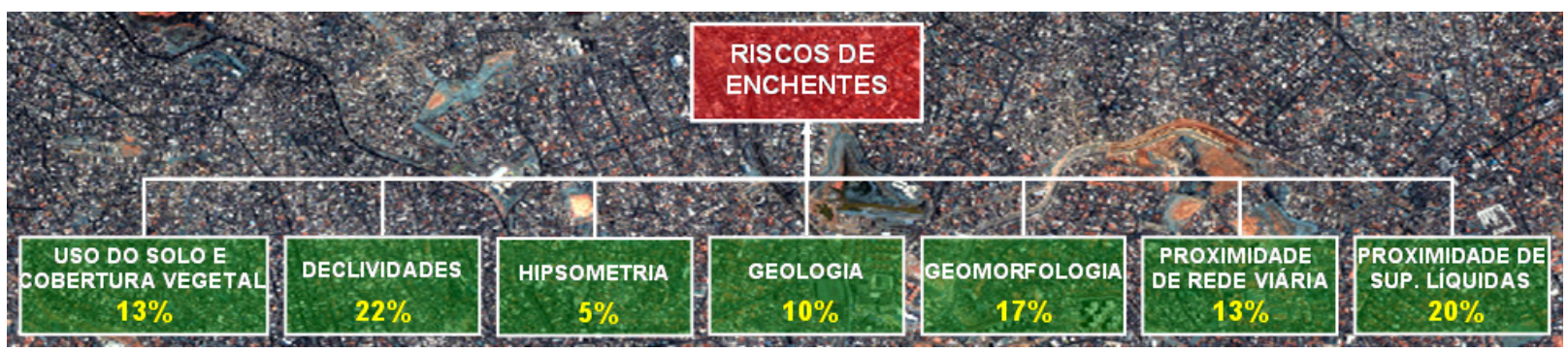

Figura 3.7 - Composição da Árvore de Riscos de Enchentes

A parte mais inferior é constituída pelos mapas digitais Uso do Solo e Cobertura Vegetal, Declividades, Hipsometria, Geologia, Geomorfologia, Proximidade de Rede Viária, Proximidade da Rede Hidrográfica. Este nível pode ser denominado Base Temática Inicial. A partir da combinação destes sete parâmetros, hierarquizados (pesos) de acordo com o grau de importância, na concepção do avaliador, será gerada a carta de Riscos de Enchentes.

\subsubsection{Riscos de Deslizamentos e Desmoronamentos - RDD}

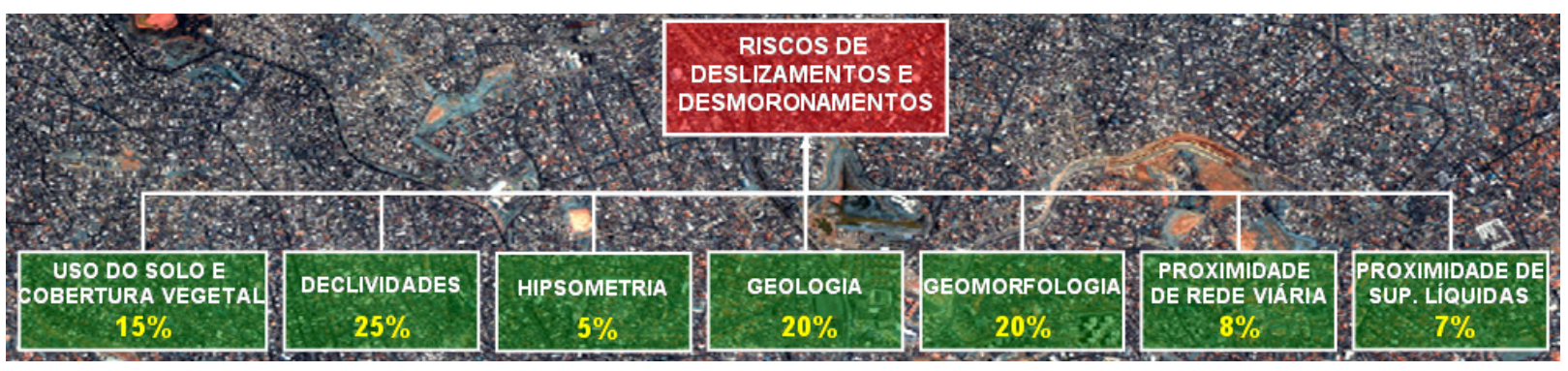

Figura 3.8 - Composição da Árvore de Riscos de Deslizamentos e Desmoronamentos 


\subsection{3. Áreas Indicadas para Transposições}

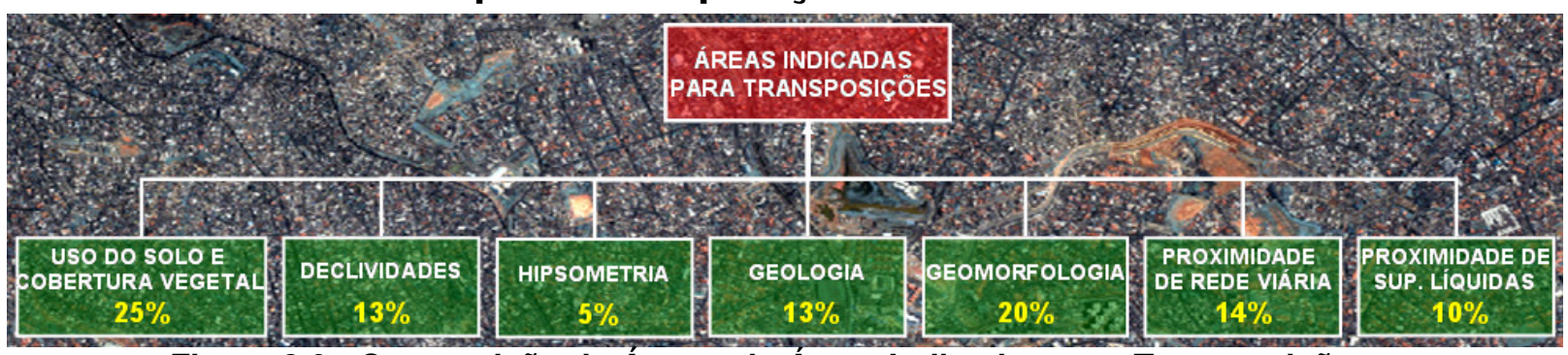

Figura 3.9 - Composição da Árvore de Areas Indicadas para Transposições

A avaliação processada na árvore acima aponta as áreas indicadas para transposições de assentamentos precários em função da conjugação dos fatores físicos apresentados como parâmetros desta análise (uso do solo, declividade, faixa altimétrica e demais condicionantes), considerados ideais para a habitação humana.

\subsubsection{Qualidade de Vida (Assentamentos Precários)}

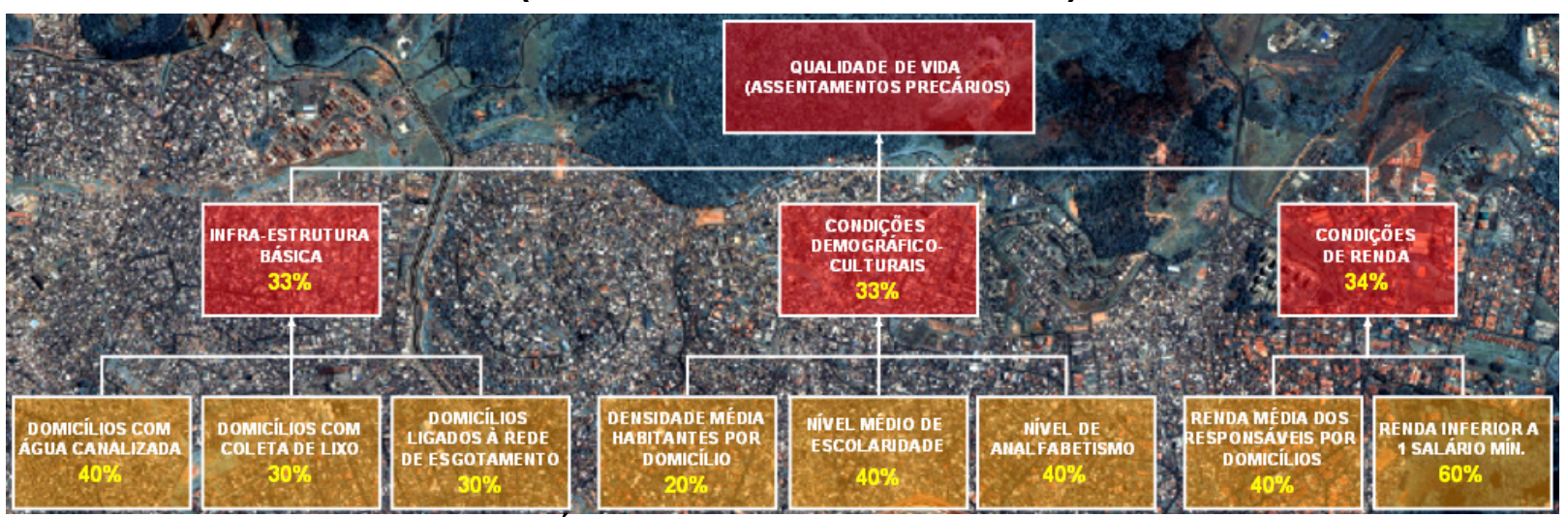

Figura 3.10 - Composição da Arvore de Qualidade de Vida (Assentamentos Precários)

Logo acima estão representados oito mapas oriundos de dados censitários. Os dois mapas à direita do observador são relativos às condições de renda dos habitantes dos setores censitários ("renda média dos responsáveis por domicílios" e "\% da população com renda inferior a um salário mínimo"). Estes dois mapas geraram, por avaliação, o mapa denominado "Condições de Renda", o qual retrata, à luz dos parâmetros usados, as condições econômicas da população. Analogamente, com os mapas "Domicílios com água canalizada", "Domicílios com coleta de lixo" e "Domicílios ligados à rede de esgotamento", situados à esquerda, neste alinhamento, foi gerado, por avaliação, o mapa "Infra-Estrutura Básica". E por último, os três mapas do meio, representados por "Densidade média de habitantes por domicílio", "Nível médio de escolaridade" e "Nível de analfabetismo" compõem as "Condições Demográfico-culturais". 
Esses três mapas ("Infra-Estrutura", "Condições Demográfico-culturais" e "Condições de Renda"), geraram, por avaliação, o mapa "Qualidade de Vida (Assentamentos Precários)", a ser utilizado posteriormente, durante a execução do nível de análise definidor de "Áreas Críticas".

Deve ser observado que neste exemplo foram considerados suficientes, para os efeitos desta demonstração metodológica, os quinze mapas básicos apresentados (sete mapas temáticos e oito mapas de origem censitária, esses últimos oito compondo o que poderia ser denominada "Base Censitária"). Entretanto, a adição de outros parâmetros mapeados pode ser providenciada e facilmente executada, na medida julgada necessária para a melhoria da avaliação. Uma recomendação, neste caso, é que as adições sejam feitas por grupamentos de parâmetros agregáveis entre si, para que o processo de triagens e adições sucessivas seja de mais fácil consecução, através de avaliações de parâmetros mapeados que sejam afins, como é o caso do mapeamento de "Infra-Estrutura" apresentado, gerado a partir de mapas digitais referentes ao abastecimento de água, do escoamento de esgotos e da coleta de lixo.

\subsection{5. Árvores de Áreas Críticas}

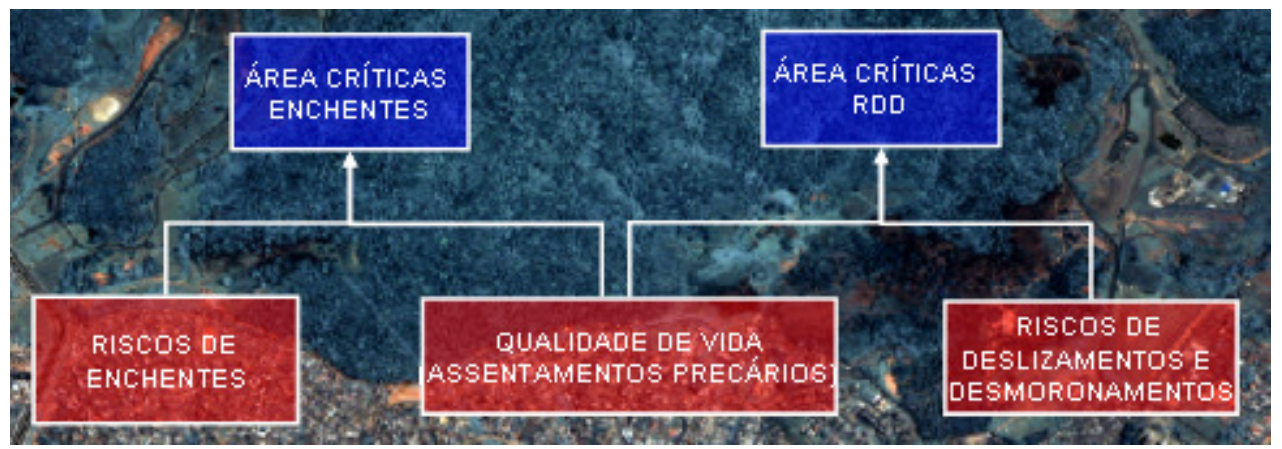

Figura 3.11 - Composição das Árvores de Áreas Críticas para Riscos de Enchentes e Riscos de Deslizamentos e Desmoronamentos

À esquerda e à direita do mapa "Qualidade de Vida (Assentamentos Precários)", e com ele constituindo o Nível das Avaliações Ambientais, estão os mapas de "Riscos de Enchentes" e "Riscos de Desmoronamentos e Deslizamentos", ambos gerados a partir da base temática inicial.

Logo acima está situado um nível mais complexo, denominado de Análise Geotopológica. É composto pelos seguintes mapas: o mapa "Áreas Críticas/Enchentes" é originado do confronto do mapa "Riscos de Enchentes" com o mapa "Qualidade de Vida (Assentamentos Precários)". Analogamente, o mapa 
"Áreas Críticas/RDD" é originário do confronto do mapa "Riscos de Desmoronamentos e Deslizamentos" com o citado mapa "Qualidade de Vida (Assentamentos Precários)". Fica assim definido um primeiro relacionamento geotopológico, com a identificação de áreas comuns entre os mapas de riscos (neste caso apenas enchentes e movimentos de encostas) e o mapa que sinaliza os locais onde já existem assentamentos precários ou nos quais tais assentamentos poderão vir a existir, por serem áreas, em princípio, carentes quanto às condições sócioeconômicas e/ou de infra-estrutura. Deve ser mencionado que nada impede que outros tipos de Áreas Críticas sejam identificados da mesma forma, bastando apenas que sejam estimados mapas de outros riscos (presença de narcotráfico, por exemplo), a serem conjugados com o mapa de "Qualidade de Vida".

\subsection{6. Árvore de Áreas Críticas para RDD e RE e Transposições Possíveis}

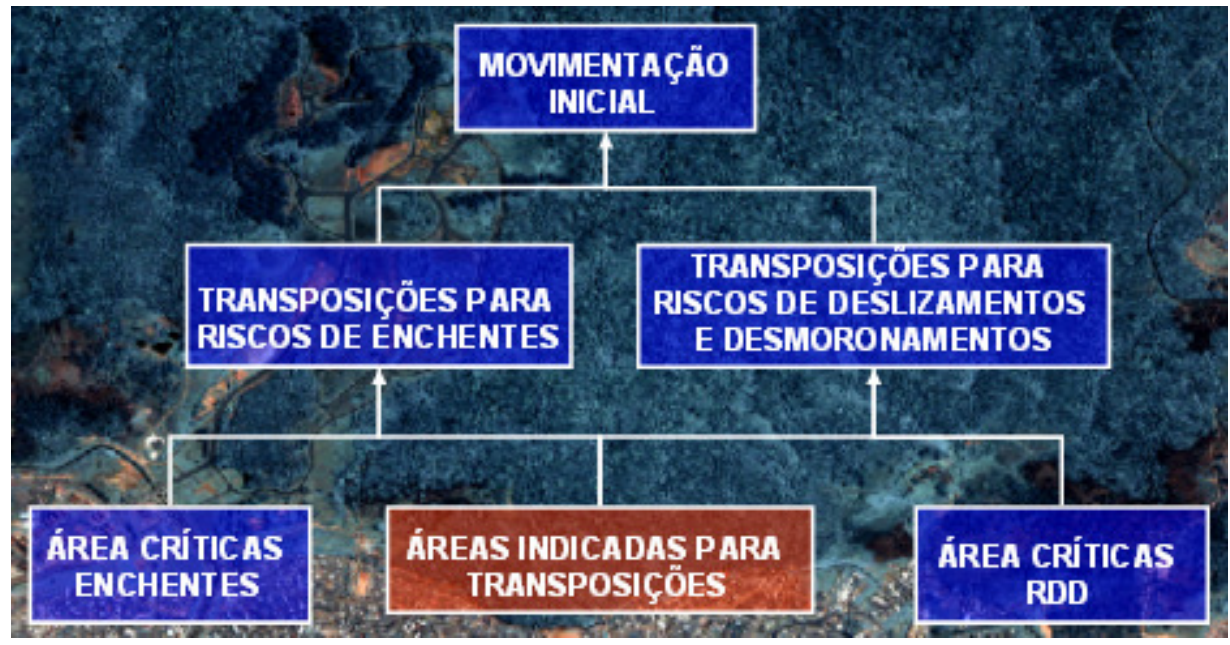

Figura 3.12 - Composição da Árvore de Áreas Críticas para RE e RDD e Transposições Possíveis

Conjugando os dois mapas do penúltimo sub-nível determinam-se as "Áreas Críticas para Riscos Deslizamentos e Desmoronamentos e Riscos de Enchentes".

Torna-se possível identificar, com apoio em definições quanto a distâncias máximas recomendáveis para transposições de população, a fim de evitar impactos econômicos e sociais, quais as áreas de riscos quanto a enchentes nas quais já existam assentamentos precários e que poderão ser transferidas para áreas melhores em termos de condições físicas, bióticas e sócio-econômicas (proximidades de vias de transporte, terrenos de topografia não acidentada e sem riscos de enchentes, por exemplo). 
Um outro produto importante deste confronto entre mapas é a identificação de assentamentos precários localizados em áreas afastadas de áreas indicadas para transposição. Para estes assentamentos outras soluções terão que ser aventadas;

uma delas, já sugerida em parágrafo anterior, sendo a criação de soluções para melhoria da qualidade de vida no próprio local onde está estabelecido o assentamento precário (favela bairro, contenção de encostas, etc).

\subsubsection{Simulações sinérgicas}

Uma simulação pode ser conceituada como sendo uma alteração fictícia ou especialmente implementada de condições físicas ou de funcionamento de uma estrutura, com vistas a verificar os resultados previstos ou imprevistos, ocorridos nas características ou no funcionamento da estrutura objeto da simulação. Apenas uma parte da estrutura (que pode ser constituída inteiramente de dados, como é o caso dos modelos digitais do ambiente) pode ser considerada na simulação; até mesmo apenas uma única relação de causa e efeito pode ser assim examinada quanto a sua sensibilidade à modificação simulada. Entretanto, quando uma estrutura total é posta a reagir á modificação fictícia ou implementada, pode-se denominar esta simulação como sinérgica, uma vez que todo a estrutura envolvida (ou uma sua grande parte) vai reagir à modificação simulada. Este é o caso das simulações praticadas na árvore de decisão apresentada, quando qualquer modificação é introduzida nos mapas que compõem as Bases Temática ou Censitária.

Um exemplo deverá trazer mais luz a estas considerações. Neste exemplo será postulado que as avaliações feitas se basearam no algoritmo da média ponderada, com pesos atribuídos aos mapas e notas atribuídas às classes de cada mapa, normalizadas as avaliações dentro do mesmo intervalo usado nas atribuições de notas.

O mapa identificado como "Mapa 10 - Taxa de domicílios com abastecimento de água canalizada" retrata a distribuição espacial do abastecimento de água na área estudada. Representa, portanto, a fonte da importância que teve 0 abastecimento de água na geração dos mapas dos níveis avaliativos colocados acima, na árvore de decisão, inclusive tendo uma contribuição na criação dos mapas "Mapa 24 - Áreas Críticas para Riscos de Desmoronamentos e Deslizamentos" e Mapa 25 - Áreas Críticas para Riscos de Enchentes. Para simular o efeito de um fictício abastecimento de água em todas as residências da área estudada basta 
zerar o peso associado ao Mapa 10, redistribuindo o seu valor pelos mapas componentes da primeira avaliação da qual participou o citado mapa. Repetida a avaliação, contendo a alteração fictícia, os mapas avaliativos e de análises geotopológicas serão sucessivamente afetados pela modificação implementada, chegando-se, ao final, a um mapa que conterá a "Movimentação Inicial" modificada pela simulação feita. As alterações encontradas no mapa final mencionado serão uma medida da importância da modificação simulada, podendo ser mensurada por planimetrias no citado mapa e nos anteriores, referentes a avaliações e análises geotopológicas.

Simulações mais complexas podem ser executadas, envolvendo alterações combinadas nos diversos pesos de diferentes mapas básicos, podendo incluir também alterações fictícias de notas em diversos locais em cada um dos mapas envolvidos na simulação. Abre-se, desta forma, todo um campo de experimentação baseado no modelo digital do ambiente (MDA) usado nas simulações, o que permite avaliar possíveis resultados ambientais - ainda sem estimativas de tempo e custo e nestes termos iniciais priorizar, previamente às suas execuções, numerosas ações hipotéticas de gestão ambiental.

\subsection{Assinatura Ambiental}

SGls permitem o trânsito entre localizações e atributos, ou seja, a recuperação da localização a partir da seleção de uma informação e vice-versa. Esta capacidade dos SGls pode ser usada em conexão com identificações de ocorrências oriundas de trabalhos de campo ou de gabinete, para a extração das chamadas assinaturas ambientais, conforme discutido a seguir.

Assinaturas espectrais são obtidas no Sensoriamento Remoto, para identificação de alvos em termos de suas respostas físicas a uma incidência de energia, ao longo de segmentações (canais, bandas) do espectro eletromagnético, por exemplo. Um referencial análogo pode ser criado, tendo como eixos os planos de informação (parâmetros) constantes do inventário de um SGI.

Uma vez definida uma ocorrência de interesse (uma área de enchentes, ou uma área com alta produtividade agrícola), que seria um alvo (uma "verdade terrestre"), a base de dados pode ser consultada sobre quais as características ambientais que se localizam na área alvo, definindo assim sua assinatura ambiental, com a identificação da área de ocorrência e varredura dos planos de informação 
georreferenciados componentes da base de dados sendo feita pelo cômputo planimétrico mencionado acima.

Assim sendo, as assinaturas ambientais são procedimentos que permitem identificar a ocorrência conjunta de variáveis, através de planimetrias dirigidas. Apresenta como uma importante ferramenta de aprendizado empírico. Por exemplo, a assinatura de todas as ocorrências reais de enchentes sobre os mapas físicos apontará a combinação dos condicionantes físicos que potencializam a probabilidade de ocorrência deste evento (MARINO e PAULA, 2007).

\subsection{Método “Delphi” para obtenção de consenso}

O "Método Delphi para Obtenção de Consenso" tem como objetivo mediar a determinação de consenso entre as diferentes opiniões de um grupo heterogêneo.

Trata-se de um método interativo e iterativo. Implica a constituição de um grupo de especialistas em determinada área do conhecimento, que respondem a uma série de questões. Os resultados dessa primeira fase são analisados, calculando-se a média e o desvio padrão. A síntese dos resultados é comunicada aos membros do grupo que, após tomarem conhecimento, respondem novamente.

As interações se sucedem desta maneira até que um consenso ou quase consenso seja obtido. As iterações do método são denominadas "rodadas" (rounds).

De modo geral, o método Delphi se distingue por três características básicas: 1) anonimato, 2) interação com feedback controlado, 3) respostas estatísticas do grupo.

O anonimato entre os participantes é um modo de se reduzir a influência de um sobre o outro, porque eles não se intercomunicam durante a realização do painel. A iteração com feedback controlado - condução do experimento numa série de etapas (rounds) e comunicando aos participantes um resumo da etapa precedente - reduz o "ruído", ou seja, o pesquisador fornece ao grupo somente aquilo que se refere aos objetivos e metas de seu estudo, evitando que o painel se desvie dos pontos centrais do problema.

O método Delphi oferece duas vantagens: seu custo é relativamente baixo e ele suprime as pressões, que os participantes poderiam ter numa confrontação facea-face.

A aplicação do método pode ser feita através do correio ou via terminais de computador. O pesquisador sumariza o cálculo da mediana ou da média da 
previsão, remetendo o resultado a cada painelista, podendo ou não incluir um relatório. Os respondentes são solicitados a revisar suas previsões, submetendo-as à comparação com os argumentos de suporte. O processo pára quando o consenso tiver sido aproximado entre os participantes. De acordo com a praxe do método Delphi, o primeiro round é composto de questões totalmente abertas (MASSAÚD, 2008).

Trata-se de um método bastante conhecido e utilizado mundialmente (NASA). Maiores informações acerca deste método podem ser encontradas através de pesquisas na Internet.

O mediador é o responsável por conduzir a discussão. A este cabe a missão de recolher as notas e guiar as discussões e defesas de opiniões de cada, nos momentos corretos.

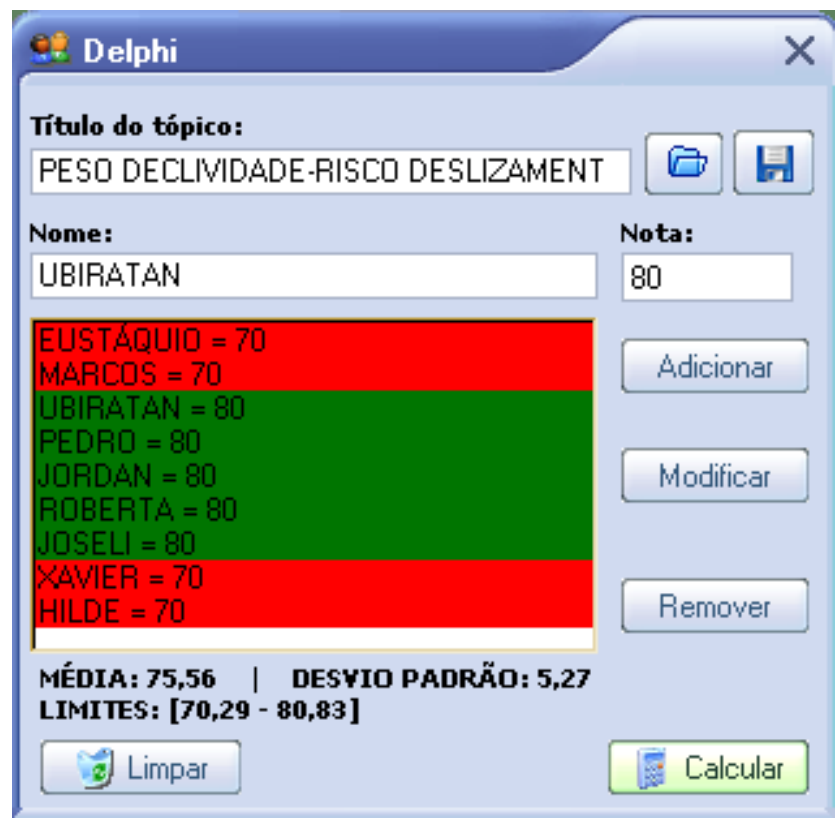

Figura 3.13 - Ferramenta Delphi, do aplicativo VISTA/SAGA definindo o peso do parâmetro declividade numa avaliação de Riscos de Deslizamentos

\section{Nomes e Notas}

Em cada rodada, cada julgador deverá entregar ao mediador um papel com seu nome e sua nota para o tópico em questão. É muito importante que cada julgador escolha sua nota, sem saber a nota dos demais julgadores naquela rodada. Isto previne a influência de terceiros na nota do mesmo.

Em posse de todos os papéis, o mediador deverá computar a nota de cada julgador e, ao final, processar os cálculos de média e desvio padrão. 


\section{Resultados}

O julgador que tiver sua nota fora do intervalo [MÉDIA - DESVIO PADRÃO, MÉDIA + DESVIO PADRÃO] terá seu nome indicado com uma tarja vermelha. Isto ocorre quando a nota do julgador estiver muito discrepante dos demais julgadores. Segundo o método, quando isto ocorre, os julgadores que estiverem fora do intervalo devem argumentar o motivo de suas notas e uma nova rodada deverá ser realizada. A situação ideal ocorre quando todos os julgadores estão dentro do intervalo, não ocorrendo discrepâncias grandes. A nota a ser adotada será a média, uma vez que a mesma leva em conta a nota de todos os julgadores.

Nem sempre a rodada terminará somente quando todos os julgadores estiverem dentro do limite (todos com nome verde). $O$ mediador pode determinar 0 fim da discussão mesmo que existam julgadores fora do limite. Assim mesmo as notas de TODOS serão levadas em conta, uma vez que a média será adotada como nota final.

\subsection{Desenvolvimento de Rotinas para o VISTA/SAGA}

Como parte do projeto foram exigidas algumas funcionalidades, ora não contempladas pelo aplicativo VISTA/SAGA. Deu-se então início à fase de elaboração de rotinas complementares, com a finalidade de viabilizar os

processamentos necessários para a criação dos mapas avaliativos. O aplicativo final, já contemplando todas as novas funcionalidades está disponibilizado como componente do volume digital, anexo a esta dissertação, juntamente com os mapas produzidos para a dissertação, no formato RASTER/SAGA (extensão rs2) e também em formato PNG (Portable Network Graphics), com acabamento para impressão. A seguir, são delineadas as principais rotinas desenvolvidas e suas respectivas aplicabilidades, dentro do escopo do presente trabalho.

\subsubsection{Ferramenta de Criação de Buffers}

Criação de faixas de distância em torno de uma classe definida pelo usuário. A criação de buffer se faz necessária nesta aplicação na elaboração dos mapeamentos de proximidades de proximidades da rede viária (Mapa 6) e de superfícies líquidas (Mapa 7).

Esta ferramenta constitui uma das inovações concebidas ao longo deste projeto. Antes os buffers eram criados, de forma mais trabalhosa, por meio da utilização de programas externos, como o Adobe Photoshop, e então identificados e classificados 
no módulo de entrada do VISTA/SAGA. Com a criação desta rotina não há mais necessidade de recorrer a outros aplicativos para a criação destas feições.

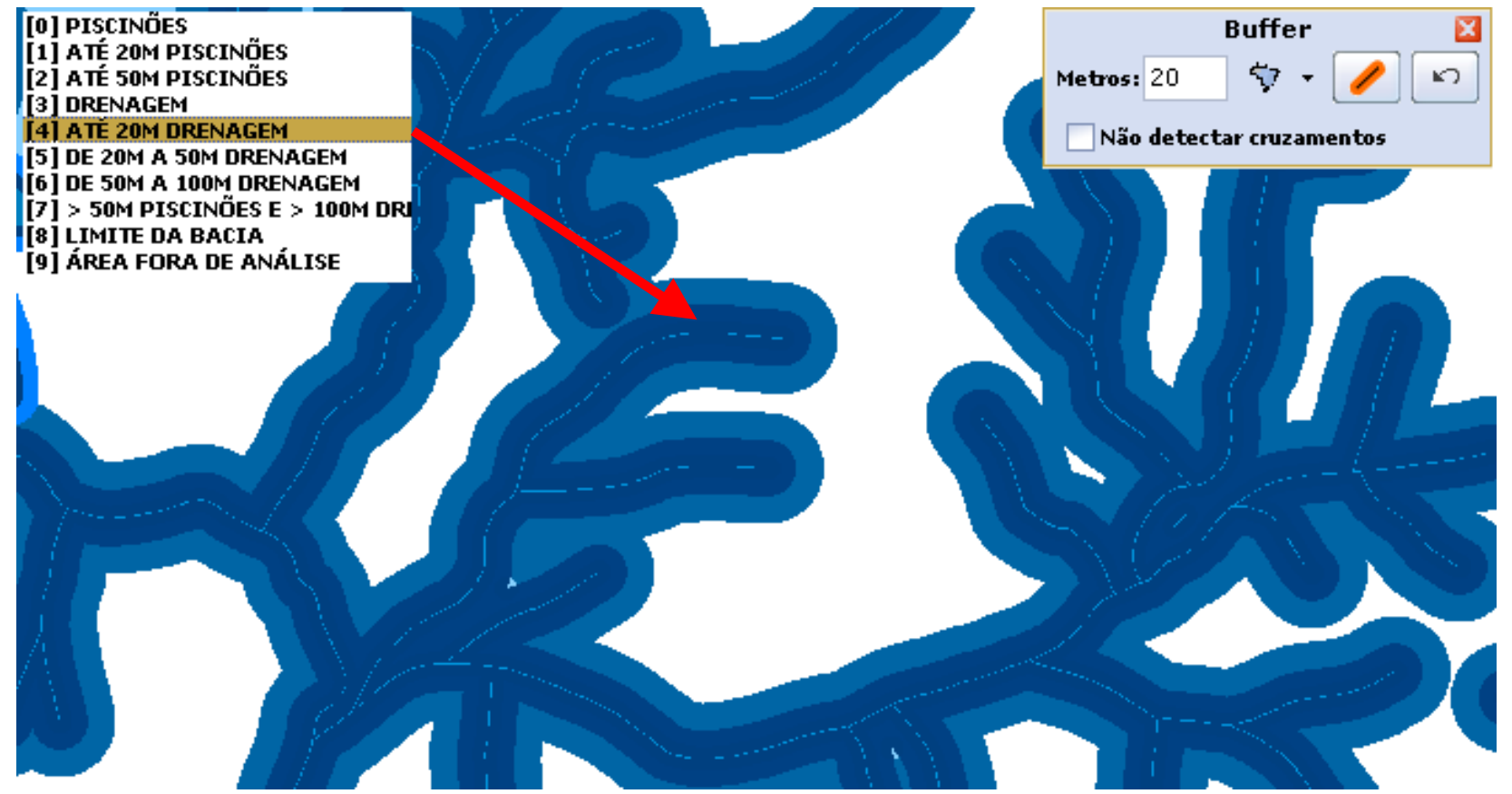

Figura 3.14 - Criação de buffer de 20 metros da rede de drenagem, no Aplicativo VISTA /SAGA

\subsubsection{O Módulo de Assinatura Espacial}

Como resultado da Assinatura Ambiental é apresentado um relatório onde são tabulados os resultados de cada uma das categorias existentes nos mapas, apresentando sua abrangência total em quantidade de pixels (Total Pixels) e hectares (Total Ha); a quantidade que foi assinada no mapa também em número de pixels (Pixels Asn.) e hectares (Área Asn. Ha); a porcentagem da legenda que foi assinada (\% Área Asn.), e a porcentagem da legenda existente no mapa analisado (\% Categoria). Os percentuais são expressos em relação à área demarcada e também em relação a todo o mapa para que o pesquisador possa realizar uma comparação da área assinada com a área total.

As planimetrias foram processadas para os mapas de áreas críticas e seus resultados são expressos no Quadro 5.8 e Quadro 5.9.

O módulo de Assinatura Ambiental já constituía a versão anterior do aplicativo, porém foram necessárias adaptações a fim de processar arquivos no novo formato em que se apresenta a base de dados da Bacia do Cabuçu (extensão rs2). 


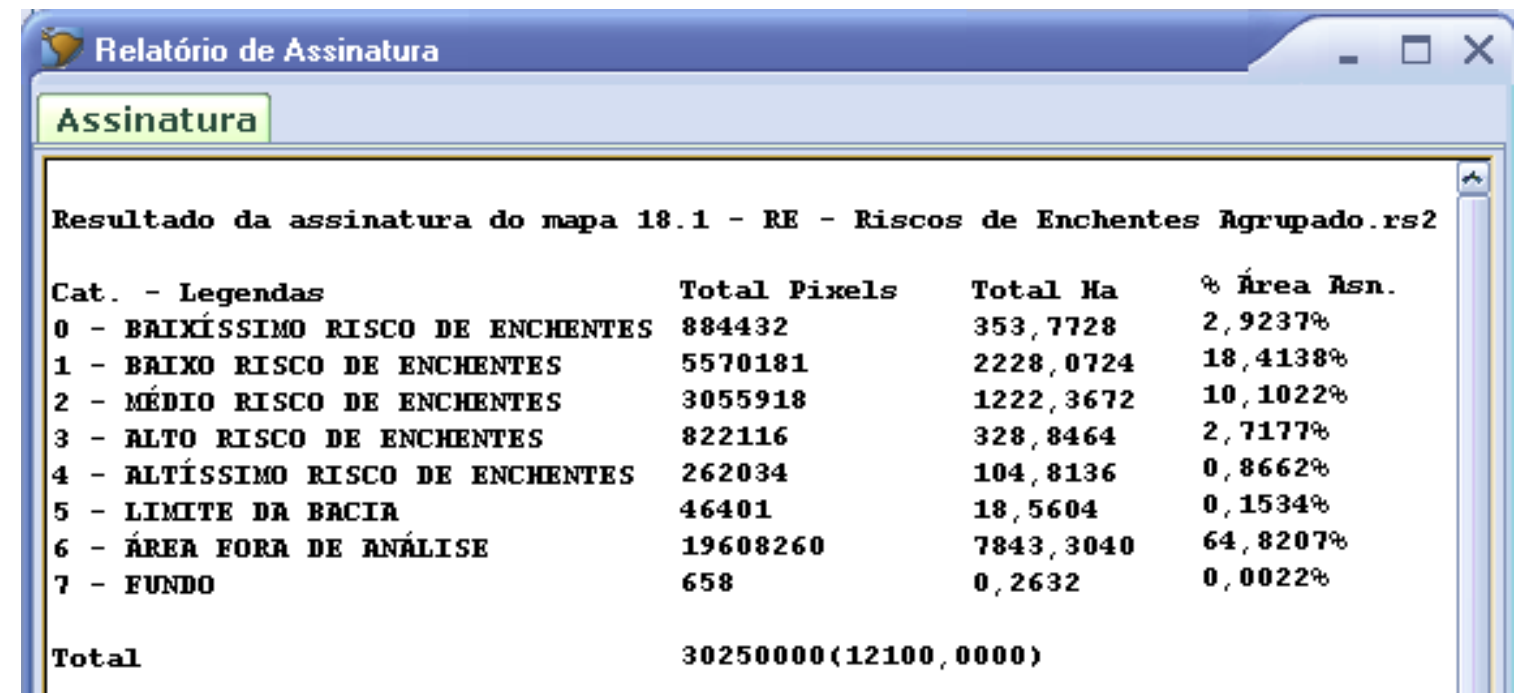

Figura 3.15 - Formato de apresentação do Relatório de Planimetria, no aplicativo VISTA/SAGA

\subsubsection{Módulo de Combinação de Mapas}

Este módulo foi utilizado para as operações de análises geotopológicas. Apresenta-se como mais uma inovação do aplicativo, com a finalidade de facilitar a tarefa de sobreposições de mapas. Antes o processamento poderia ser realizado, porém de forma bastante trabalhosa, por meio do módulo de Análise Ambiental, distribuindo iguais valores de pesos entre os mapas a serem combinados. O processo anterior para elaboração de mapeamentos oriundos das análises geotopológicas é recorrentemente citado em MELO FILHO (2003). A criação da ferramenta simplificou o procedimento, tornando-o menos custoso, em termos de tempo, sendo esta uma solução objetiva para a tarefa proposta.

Para entrada deste módulo são solicitados dois mapas de formato Raster/SAGA (.rst,.rs2), sendo o mapa 1, com $\mathrm{N}$ legendas e o mapa 2, com M legendas, ambos abrangendo a mesma porção territorial. Como saída, é gerado um mapa, também no formato Raster/SAGA com, no máximo, $\mathrm{N}^{\star} \mathrm{M}$ legendas onde são mapeadas todas as combinações das classes de ambos mapas. As legendas serão representadas no seguinte formato: $n 1+m 1, n 1+m 2, n 1+m 3, \ldots, n n+m 1, n n+$ $m 2, \ldots, n n+m m$, onde "+" é o caracter separador, definido pelo usuário.

A elaboração dos mapeamentos de Áreas Críticas e Transposições Indicadas foi conduzida pela ferramenta "Combinação de Mapas". O "Mapa 24 - Áreas Críticas para Riscos de Desmoronamentos e Deslizamentos", por exemplo, foi gerado a partir da combinação entre as cartas de Riscos de Enchentes e Qualidade de Vida, (blocos azuis da Árvore de Decisão, Figura 3.6) mapeando todas as combinações 
possíveis de riscos com qualidade de vida. A Figura 5.1 - Classes resultantes da combinação entre Qualidade de Vida x RDD.

\subsubsection{Módulo de Análise Ambiental}

Ferramenta utilizada para conduzir as avaliações ambientais de nível Avaliativo (blocos vermelhos da Árvore de Decisão, Figura 3.6). Processa a avaliação ambiental, segundo a formulação proposta no tópico 3.2.3. O processamento resulta num mapa com classes representadas por notas entre $0 \mathrm{e}$ 10 , onde as notas mais baixas são atribuídas às localidades de menor risco/potencial de ocorrência do evento analisado e as maiores, para localidades de maior risco/potencial. O módulo de Análise Ambiental já fazia parte da versão anterior do aplicativo, porém não processava mapas de formato rs2 e tampouco permitia o armazenamento dos pesos e notas forma de arquivo de projeto (extensão .ava). Como as análises são freqüentemente reproduzidas havia a necessidade de digitação de todos os valores de pesos e notas a cada vez que se processa uma nova avaliação. Isto aumenta o tempo de trabalho, além de aumentar a probabilidade de erro na entrada dos parâmetros avaliativos. A interface do módulo também foi reconstruída de modo a torná-lo mais intuitivo e objetivo para o usuário.

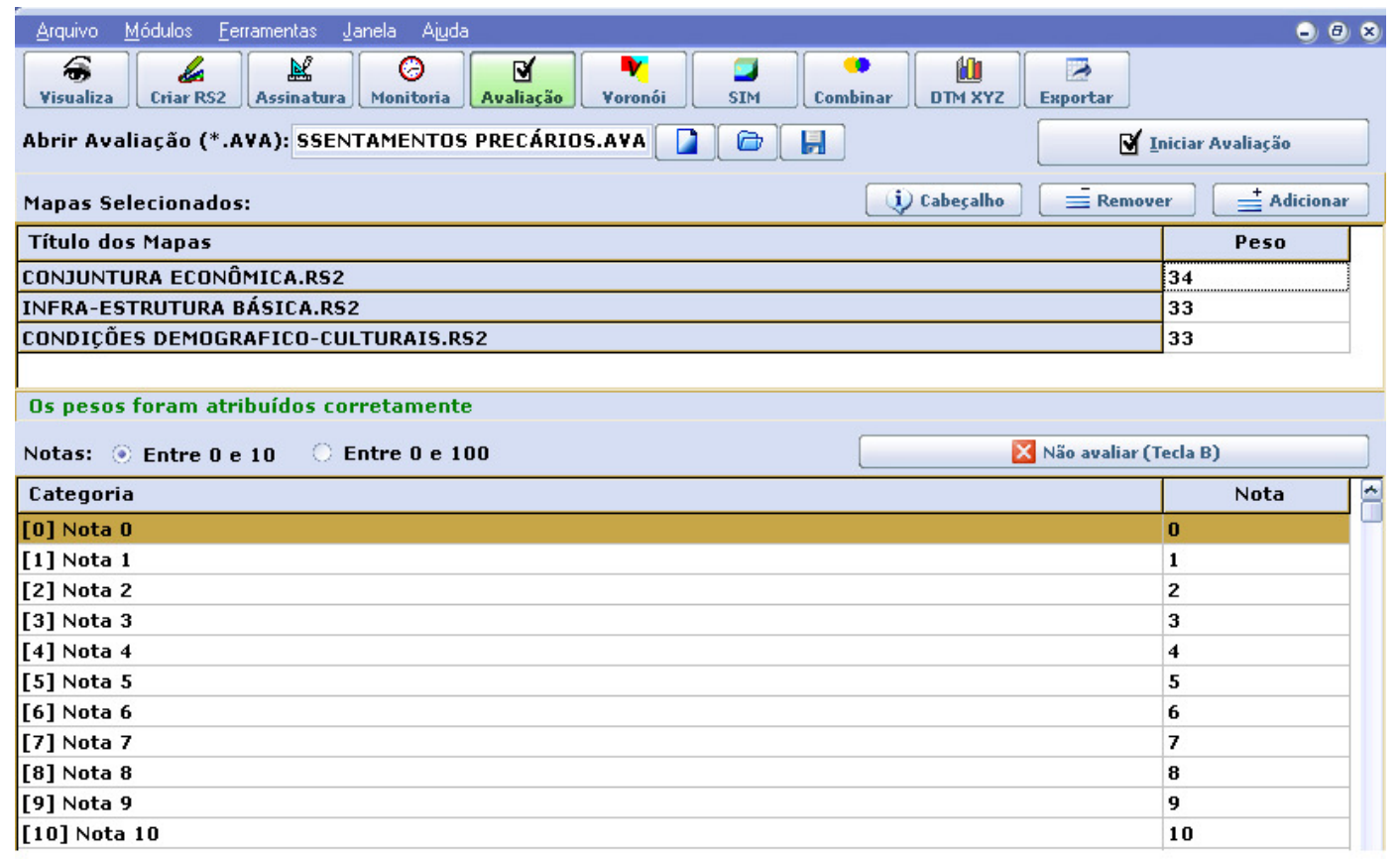

Figura 3.16 - Procedimento de Análise Ambiental para Qualidade de Vida

\subsubsection{Criação de Mapas Temáticos}

Possibilita a criação mapas temáticos a partir de dados de tabelas provenientes do Censo/IBGE (no formato Database File, com extensão DBF). Toda 
a base de dados sócio-econômica, apresentada no tópico 4.3 foi criada a partir desta ferramenta, no VISTA/SAGA.

A ferramenta dispõe de vários métodos de classificação, como Intervalos Iguais, Quantil, Quebras Naturais e também um método personalizado, onde o próprio usuário define os pontos de quebra das classes. Também podem ser realizadas classificações normalizadas por outros campos da tabela, definição de número de casas decimais de precisão, query, dentre outras funcionalidades. Maiores detalhes acerca desta ferramenta, bem como as demais funcionalidades do VISTA/SAGA podem ser encontradas em MARINO e PAULO (2007).

\subsubsection{Módulo de Exportação de Mapa}

Permite, ao término das análises, a conversão (exportar) arquivos de formato nativo Raster/SAGA ( ${ }^{*}$.rst, ${ }^{*}$.rs2) para formatos populares (Bitmap, Png, Tiff). Estes, por sua vez, podem ser interpretados por quaisquer aplicativos gráficos como Adobe Photoshop, Corel Draw, entre outros, onde os mapas podem ser melhor diagramados, re-posicionando as legendas, informações extras como fonte, cabeçalho, para a publicação final do mapa. 


\subsection{Metodologia para a Base de Dados Sócio-econômica}

As modificações nas paisagens naturais, por efeito de intemperismos e ações dos agentes da natureza sobre os ambientes físicos e bióticos, são consideradas, via de regra, como parte de processo espontâneo de evolução fisiográfica e sinecológica. Quando a essas paisagens estão associadas áreas urbanizadas, intensamente com elas relacionadas e mesmo interdependentes, então àquelas alterações é geralmente atribuído um significado de prejuízo ambiental. Por outro lado, às cidades pode estar vinculada uma complexa problemática ambiental, quando a estrutura urbana e seus mecanismos e formas de gestão crescem dissociados de planejamento orientado com o sentido holístico que hoje se confere ao meio ambiente.

A busca de conhecimentos sobre o ambiente, ao início das pesquisas científicas, privilegiou os aspectos físicos e bióticos. Compreende-se hoje por ambiente, e vale reafirmar, como o conjunto estruturado de elementos que oferecem espacialidade, os quais abrangem as diferentes áreas do conhecimento, alicerça-se na integração e simbiose entre seus componentes, e são também de natureza social e política.

Neste trabalho, pesquisou-se a integração da temática ambiental do meio físico com os dados populacionais atualizados, obtidos do Censo 2000, pois ressalta-se como questão fundamental no estudo do meio ambiente as implicações também das análises demográficas e sócio-econômicas.

\subsection{1. Índices de Desenvolvimento Humano e de Qualidade de Vida}

O desenvolvimento humano por definição é compreendido como um abrangente processo de expansão de escolhas individuais nas diversas áreas, como: geográfica, econômica, social, cultural e política. Embora, saiba-se que a possibilidade não é satisfeita, de as pessoas terem o discernimento ou condições de exercerem esse direito, que é internacionalmente reconhecido nas cartas de cidadania, e foco de assunto constitucional brasileiro, algumas dessas escolhas são básicas para a vida humana. As opções por vida saudável, por adquirir conhecimento, por morar dignamente e por atingir e manter um padrão de vida decente são condições fundamentais para os seres humanos e, à medida que sejam alcançadas, abrem caminho para outras escolhas igualmente importantes, referentes 
à participação política, à diversidade cultural, aos direitos humanos e à liberdade individual e coletiva (IPEA,1998).

O conceito de desenvolvimento humano não é propriamente novo, pois filósofos e pensadores da antiguidade, inclusive geógrafos, abordaram essa temática. Pesquisadores recentes, ligados às especialidades da economia, passaram a considerar em suas análises o desenvolvimento como resultante apenas de aspectos materiais, em que os seres humanos são considerados como insumos do processo produtivo e não como beneficiários do processo. A nova ótica a respeito das condições associadas aos valores humanos, que ocorreu a partir do referido RDH 1990, devolveu ao desenvolvimento humano lugar de destaque, ao considerar que o papel dos seres humanos não deve ser apenas de força produtora, mas de beneficiário principal.

Segundo IPEA (1998), o conceito atual de desenvolvimento humano é amplo, pois, além de considerar os seres humanos como participantes ativos do processo de desenvolvimento, os tem como beneficiários do processo produtivo, e vê suas necessidades básicas monitoradas a partir dos citados requisitos mínimos e de suas escolhas. A idéia de desenvolvimento humano, ao integrar todos esses conceitos, que sintetizam a capacidade de bem-estar e da qualidade de vida, representa uma noção abrangente de desenvolvimento, com sentido holístico.

Os censos demográficos efetuados e entregues pelo IBGE, por sua riqueza de dados e informações, permitem que sejam elaborados diversos tipos de índices de desenvolvimento, que podem abarcar os conceitos econômicos, sociais e ambientais.

Segundo IPEA (1998), a vantagem de se aproveitar a base de dados censitária, ainda relativamente pouco explorada em trabalhos científicos e técnicos, é que ela permite incorporar outras variáveis e dimensões à análise do desenvolvimento humano.

Os índices sintéticos de desenvolvimento humano ocorrido no Brasil, atualmente, são o Índice de Desenvolvimento Humano Municipal (IDHM) e o Índice de Condições de Vida (ICV). Para sua construção são gerados e empregados diversos indicadores. $\mathrm{O}$ objetivo do índice sintético, que permite a comparação e ordenação entre comunidades, é reduzir todos os indicadores, por ponderações e juízos de valor, a um índice único. O IDHM, para sua concepção, precisa ultrapassar certos conceitos básicos do IDH, que foi idealizado para ser calculado e comparar 
países. Para sua avaliação, consideram-se três dimensões: Educação, Renda e Longevidade. O ICV, para a sua construção, considera cinco grupos de indicadores: Educação, Renda, Habitação, Infância e Longevidade. Cada uma dessas dimensões é estruturada a partir de diversas variáveis.

Esses índices têm sido empregados no Brasil com a incorporação dos dados censitários históricos, estando mais difundidos os relativos aos censos de 1970 a 2000. Tanto o IDHM como o ICV generalizam os dados para municípios e permitem a comparação segundo essas unidades.

Neste trabalho, empregam-se as variáveis disponibilizadas por IBGE (2002), em que, ao destacar uma região da cidade de São Paulo, avançou-se quanto à questão da escala e se evitou a generalização padronizada daqueles supracitados índices, ao considerar como unidade básica o Setor Censitário.

Nas análises que ora apresenta-se, privilegiaram-se as seguintes dimensões e variáveis ambientais relativas à população, além das anteriormente detalhadas, referentes ao mundo físico da região da Bacia do Cabuçu:

\section{1) Infra-estrutura básica do estado e do indivíduo:}

Variáveis: - Domicílios com água canalizada da rede geral

- Domicílios com coleta de lixo por serviço de limpeza

- Domicílios ligados à rede esgotamento

Dentre os itens essenciais a serem tratados na quantificação do nível de desenvolvimento, destaca-se a habitação, necessidade básica do ser humano. Uma moradia adequada e digna é uma das condições determinantes para a qualidade de vida da população (IBGE, 2004).

Quanto ao abastecimento de água, emprega-se o valor percentual da população que vive em domicílios com abastecimento adequado de água. Considera-se apropriado à boa qualidade de vida o abastecimento através de rede geral com canalização interna ou através de poço ou nascente com canalização interna no domicílio.

Quanto às instalações de esgoto, emprega-se 0 valor percentual da população que vive em domicílios com instalações sanitárias não compartilhadas com outro domicílio, e com escoamento através de fossa séptica ou rede geral de esgoto. 
Quanto à coleta de lixo, emprega-se o valor percentual da população que vive em domicílios que são atendidos por serviço oficial de limpeza.

\section{2) Condições sociais e herança cultural:}

Variáveis: - Densidade média de habitantes por domicílio

- Nível médio de escolaridade

- Nível de analfabetismo

A escolaridade da população é um dos indicadores-chave, juntamente à alfabetização de adultos e ao analfabetismo, para o conhecimento da situação ambiental e da qualidade de vida da população de uma comunidade. Segundo IBGE (2004), a inserção em um mercado de trabalho competitivo e exigente de habilidades intelectuais depende de um ensino prolongado e de qualidade.

\section{3) Condições de Renda:}

Variáveis: - Renda média dos responsáveis por domicílios

- Responsáveis com renda inferior a 1 salário mínimo

A renda é freqüentemente utilizada para se auferir o nível de bem-estar de uma comunidade. Segundo CORSEUIL e FOGUEL (2002), seu uso se justifica pela associação dessa variável com a capacidade de um indivíduo, ou sua família, consumir bens e serviços que the proporcionem satisfação ou bem-estar.

Parte-se, pois, do pressuposto de que áreas que congregam predominante população com maiores níveis de educação e de renda constituem núcleos que se caracterizam por oferecer maior bem-estar e melhores condições de vida para as pessoas residentes ou freqüentadoras desses locais.

\subsubsection{Terminologia Censitária (IBGE)}

A seguir são apresentados alguns termos, freqüentemente citados nos capítulos que discutem o aspecto sócio-econômico dos mapeamentos, definidos segundo IBGE (2008):

Domicílio particular - Moradia de uma pessoa ou de um grupo de pessoas, onde o relacionamento é ditado por laços de parentesco, dependência doméstica ou normas de convivência. $O$ domicílio particular é classificado em permanente - localizado em 
unidade que se destina a servir de moradia (casa, apartamento ou cômodo) e improvisado - localizado em unidade que não tem dependência destinada exclusivamente à moradia (loja, sala comercial, prédio em construção, embarcação, carroça, vagão, tenda, barraca, gruta etc. que esteja servindo de moradia).

Rendimento mensal - soma do rendimento mensal de trabalho com o rendimento proveniente de outras fontes.

Rendimento mensal familiar - Soma dos rendimentos mensais dos componentes da família, exclusive os das pessoas cuja condição na família fosse pensionista, empregado doméstico ou parente do empregado doméstico.

Taxa de analfabetismo - percentagem das pessoas analfabetas $\left({ }^{*}\right)$ de um grupo etário, em relação ao total de pessoas do mesmo grupo etário.

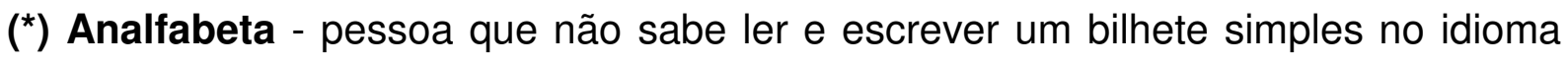
que conhece.

Domicílio com água tratada - domicílio particular permanente servido por água canalizada proveniente de rede geral de abastecimento, com distribuição interna para um ou mais cômodos.

Domicílio com esgoto ligado a rede coletora (ou fossa séptica) - domicílio particular permanente em que o escoadouro do banheiro ou sanitário de uso dos seus moradores é ligado à rede coletora ou à fossa séptica.

Rede coletora - quando a canalização das águas servidas ou dos dejetos é ligada a um sistema de coleta que os conduz para o desaguadouro geral da área, região ou município, mesmo que o sistema não tenha estação de tratamento da matéria esgotada; fossa séptica - quando as águas servidas e os dejetos são esgotados para uma fossa, onde passam por um tratamento ou decantação, sendo a parte líquida absorvida no próprio terreno ou canalizada para um desaguadouro geral da área, região ou município. 


\subsubsection{Procedimentos estatísticos e classes de dados}

O número de domicílios registrados por setor censitário na bacia do Cabuçu varia enormemente, dependendo da localização do setor. Para a exposição dos dados tabulares sob a expressão cartográfica, há a necessidade de se efetuar o agrupamento desses dados em classes.

Através da utilização do módulo de criação de mapas temáticos do VISTA/SAGA (item 3.6.5), concluiu-se pelo emprego de 10 classes. Este raciocínio atendeu à aplicação computacional da formulação de Sturges, que orienta qual deva ser o número de categorias, de acordo com a quantidade de dados disponíveis, neste caso, o número total de setores censitários da área de estudos (442).

\section{$K=1+3,3^{\star} \log 442=1+3,3^{\star} 2,65=1+8,73 \approx 10$ classes}

\subsubsection{Análise baseada em valores relativos (taxas percentuais)}

É importante observar que não faz sentido realizar as classificações a seguir sem normalizá-las pelo campo que tabula a quantidade de domicílios permanentes. Para a melhor compreensão desta citação, segue uma breve ilustração:

\begin{tabular}{|c|c|c|c|}
\hline SETOF & $\begin{array}{c}\text { DOMICÍLIOS ABASTECIDOS DE } \\
\text { ÁGUA PELA REDE GERAL }\end{array}$ & $\begin{array}{c}\text { TOTAL DE DOMICÍLIOS } \\
\text { DO SETOR }\end{array}$ & PORCENTAGEn \\
\hline 1 & 50 & 100 & $50 \%$ \\
\hline 2 & 50 & 1000 & $5 \%$ \\
\hline
\end{tabular}

Quadro 3.1 - llustração da necessidade de normalização das classificações

Apesar de ambos setores apresentarem as mesmas quantidades de domicílios abastecidos pela rede de água, o setor 1 possui apenas 100 domicílios, ou seja, $50 \%$ deste setor é atendido pela rede de água. Analisando agora o setor 2 , que possui também 50 domicílios com abastecimento da rede, este possui 1000 domicílios. Em termos percentuais este setor possui apenas $5 \%$ de seus domicílios abastecidos pela rede geral.

Portanto todos os dados serão sempre classificados, normalizados pela quantidade de domicílios do setor. Sendo assim pode-se obter a resposta em termos percentuais.

\subsubsection{Análise baseada em valores absolutos}

Vale observar que nem sempre se deve trabalhar com dados relativizados. Em casos de aplicação de recursos para regiões carentes, o gestor deve sempre verificar os valores absolutos pois, ao contrário da ilustração supracitada, o valor 
percentual pode "mascarar" a distinta realidade entre dois cenários, à primeira vista, semelhante. Para melhor compreensão o Quadro 3.2 ilustra a situação levantada.

Supondo que existam 10 milhões de reais para investimentos em educação. Quando analisamos o percentual de analfabetismo entre dois setores verifica-se que ambos possuem a mesma taxa de analfabetismo, 50\%. Porém, isto não significa que ambos deverão receber a mesma quantia. Ao analisar o valor absoluto de pessoas analfabetas em cada setor, constata-se a evidência que seria um equívoco investir a mesma verba para ambos setores. É notório que o setor 2 apresenta um quadro de analfabetismo muito mais grave do que o setor 1 , devendo o setor 2 receber maior quantia de recursos para investimentos em educação.

\begin{tabular}{|c|c|c|c|}
\hline SETOF & PESSOAS ANALFABETAS & TOTAL DE PESSOAS & PORCENTAGEI \\
\hline 1 & 40 & 100 & $40 \%$ \\
\hline 2 & 400 & 1000 & $40 \%$ \\
\hline
\end{tabular}

Quadro 3.2 - Ilustração de caso de análise baseada em valores absolutos 


\section{RECURSOS EMPREGADOS NA PESQUISA}

\section{1. Área de Estudo: Bacia do Córrego Cabuçu de Baixo - Características e Complexidade}

O Córrego do Cabuçu de Baixo é um dos afluentes da margem direita do rio Tietê, com sua foz situada próxima à ponte da Freguesia do Ó. Sua bacia hidrográfica está localizada ao norte do Município de São Paulo, possui uma área aproximada de $42 \mathrm{~km}^{2}$ e é composta por vários outros córregos cujas nascentes estão ao norte, dentro do Parque Estadual da Cantareira, um dos mais importantes remanescentes de Mata Atlântica do Município de São Paulo e considerado pela UNESCO como reserva da biosfera, ocupando $30 \%$ de toda a bacia.

A bacia é constituída por relevo de morros e montanhas com grandes declividades na sua porção norte, que vai suavizando até alcançar na sua porção final a planície aluvial do Rio Tietê. A região de relevo mais acidentado, antiga zona rural, é justamente aquela com ocupação mais recente, caracterizada por invasões e ocupações desordenadas que provocam intenso desmatamento em áreas de risco geológico. Na bacia existem aproximadamente 150 favelas, sendo 28 localizadas em áreas críticas de risco geotécnico, todas na porção norte da bacia (ATLAS, 2002).

A escolha da Bacia do Córrego Cabuçu de Baixo como "área piloto" para os estudos se deu, essencialmente, devido à diversidade de cenários apresentados por esta região. Fatores naturais, sócio-econômicos, terrenos acidentados, presença de várzeas, declives muito e pouco acentuados, que quando combinados, resultam numa gama maior de resultados.

\subsubsection{Crescimento e evolução da periferia}

O crescimento populacional ocorrido no século passado e a valorização da vida urbana em detrimento da vida no campo gerou um grande fluxo populacional às cidades, principalmente as de grande porte, e um aumento do crescimento demográfico dessas cidades. Esse fenômeno, apesar de responsável em grande parte pelo enriquecimento desses centros urbanos gerou também empobrecimento de uma grande parte da população, devido à incapacidade de acomodação e atendimento as necessidades urbanas básicas desse contingente de pessoas, uma vez que não há oferta suficiente de emprego e moradia para todos. 
Nestes centros urbanos, como por exemplo a Região Metropolitana de São Paulo, a região periférica, onde está acomodada a maioria da população de baixa renda, é a que mais tem problemas estruturais urbanísticos de uso e ocupação do solo e de qualidade ambiental.

As regiões periféricas estão geralmente concentradas nas extremidades das cidades e são caracterizadas pela ocupação informal de espaços urbanos, públicos ou privados, de forma intensa e desordenada, sem a intervenção do estado, com infra-estrutura precária e constituída basicamente de moradias improvisadas, sem planejamento algum. Esta desorganização na ocupação e uso do solo gera a falta de escolas, áreas verdes, centros de lazer, calçamento das ruas e saneamento básico. A dinâmica das mudanças nas regiões periféricas impulsionadas pela rápida construção das casas populares e pela acomodação do grande número de pessoas, devido ao grande adensamento populacional tornam difícil o trabalho de atendimento das demandas urbanas básicas.

$\mathrm{Na}$ área da Bacia do Córrego Cabuçu de Baixo observa-se grande expansão da periferia nos moldes colocados acima, crescimento desordenado, casas autoconstruídas, ocupações irregulares nas margens dos rios, nas encostas da Serra da Cantareira, invasão de terrenos públicos e privados e o início de ocupação de áreas de preservação ambiental do Parque Estadual da Serra da Cantareira, implicando um grande custo ambiental e social, pois as áreas verdes são ocupadas sem nenhum estudo ou critério, gerando um grande prejuízo da qualidade de vida dos moradores das regiões periféricas.

De acordo com a contagem do Censo realizado pelo IBGE em 2.000, a população residente na área abrangida pela bacia do Cabuçu totaliza cerca de 390 mil habitantes.

Desconsiderando os fatores sociais e econômicos envolvidos, a heterogeneidade da mancha urbana na bacia pode ser notada pelas diferenças no padrão das edificações (aglomeração, dimensão, forma), no sistema viário (pavimentação, largura e a não uniformidade no traçado). Grande parte das áreas, localizadas próximas ao limite entre regiões de cobertura florestal e urbana, é tomada por um processo de ocupação irregular (NOBREGA, 2007). Uma descrição detalhada das características físicas, sociais, bem como o processo de urbanização da região onde se localiza a área de estudo pode ser vista em Barros (2004) e Barros et al (2005). 
O número de edificações instaladas nessas áreas aumentou consideravelmente nas últimas décadas, sem seguir um planejamento para comportar tal crescimento urbano. De forma análoga, o sistema viário foi sendo formado de modo a suportar o escoamento da população residente. Verifica-se, com isso, a heterogeneidade com que as ruas têm sido formadas. Outro ponto fundamental a ser considerado é a predominância de um relevo acidentado (descrito em detalhes em NOBREGA, QUINTANILHA e BARROS, 2005), acentuando, ainda mais, as características mencionadas.

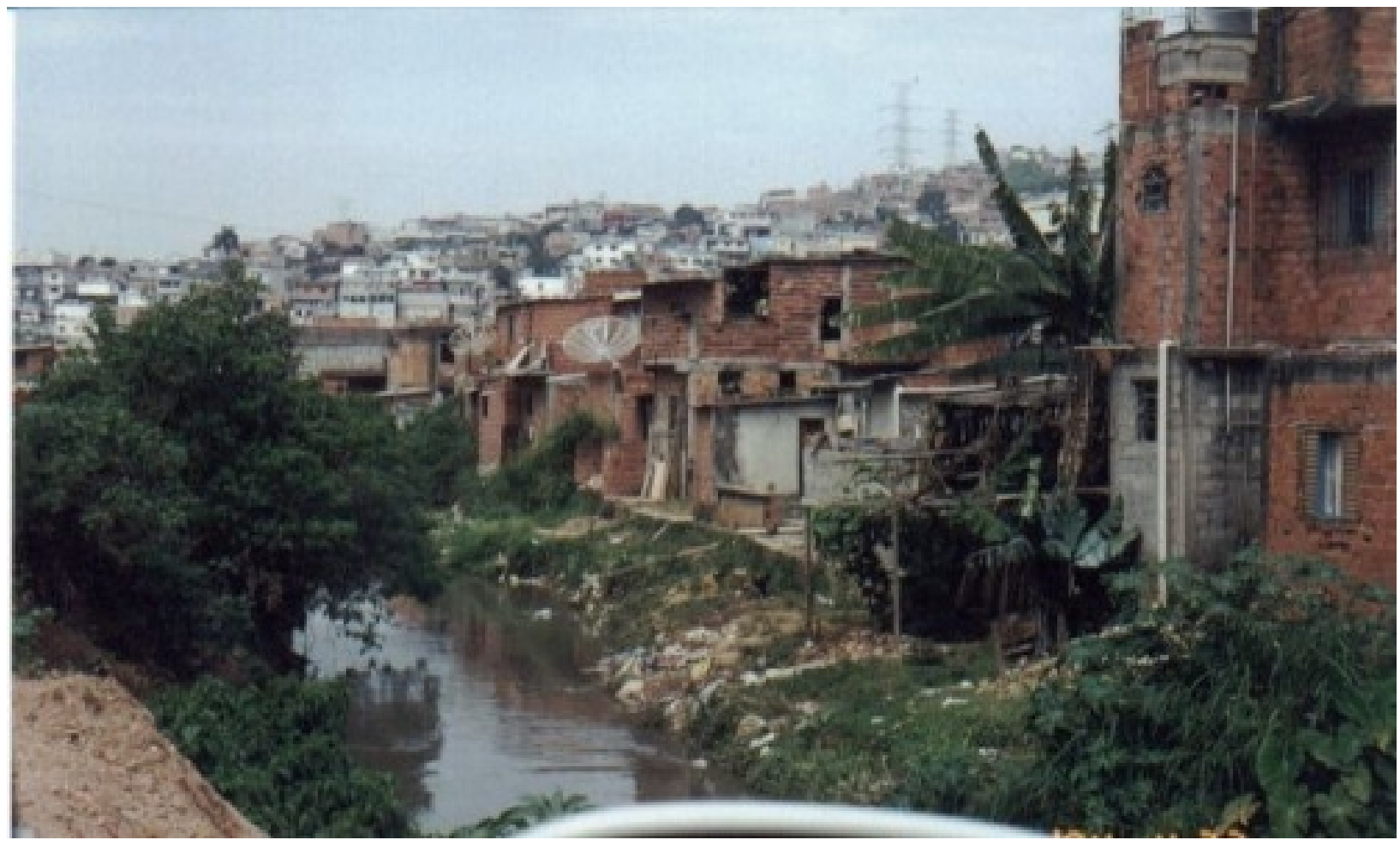

Figura 4.1 - Rios assoreados: degradação decorrente da ocupação sem planejamento na região (BARROS, 2004) 


\subsection{2. Área de Abrangência do Estudo}

O Córrego Cabuçu de Baixo é afluente do Rio Tietê pela sua margem direita, tendo suas nascentes junto a Serra da Cantareira. Localiza-se na região norte da cidade de São Paulo e tem, como bacias hidrográficas vizinhas, a leste o Córrego do Mandaqui e a oeste, o Córrego das Pedras e o Ribeirão Verde.

Com a área de drenagem somando 4238 hectares $\left(42,38 \mathrm{~km}^{2}\right)$, são seus formadores principais o Córrego do Bananal, correndo na direção oeste-leste, o Córrego Itaguaçu, em direção norte-sul, e os córregos Bispo e Guaraú, em direção leste-oeste.

A região do Córrego Cabuçu de Baixo tem parte de sua ocupação consolidada de há muito e, outra parte, notadamente nas cabeceiras, com um processo de urbanização acelerado e completamente desordenado, mais recente um cenário corriqueiro em nosso país.

Essa área é composta por floresta tropical densa e moderada, situada em terreno acidentado, cuja remoção para a introdução da ocupação têm gerado problemas ambientais.

Grande parte das áreas, localizadas próximas ao limite entre regiões de cobertura florestal e urbana, é tomada por um processo de ocupação irregular.

Bairros como Vila Brasilândia, Parada de Taipas e Vila Nova Cachoeirinha, entre outras, estão totalmente ou em grande parte dentro dessa bacia.

O polígono que circunscreve a região de estudos está posicionado geograficamente segundo o sistema de projeção Universal Transversa de Mercator e definido pelas coordenadas métricas:

\begin{tabular}{|l|l|}
\hline Fuso: & $23 \mathrm{~K}$ \\
Coordenadas UTM NE: & $7410000: 334000$ \\
Coordenadas UTM SW: & $7399000: 323000$ \\
Datum: & Córrego Alegre \\
\hline
\end{tabular}

Quadro 4.1 - Coordenadas delimitadoras da área de estudo

\subsection{3. Área das sub-bacias}

Hidrologicamente a bacia em estudo está dividida em 5 sub-bacias (Figura 4.2): Bispo, Bananal, Guaraú, Imobel e Córrego Cabuçu de Baixo. São cerca de 110 quilômetros de rios, alternando trechos canalizados (em galeria e aberto), em processo de canalização, com ocupação (em sua maioria irregulares) nas margens e ou margens em estado natural.

\begin{tabular}{|c|c|c|}
\hline Sub-Bacia & Área & Ocupação Bacia \\
\hline BISPO & 7,09 & 16,74 \\
\hline
\end{tabular}




\begin{tabular}{|c|c|c|}
\hline BANANAL & 13,60 & 32,13 \\
\hline GUARAÚ & 9,62 & 22,72 \\
\hline IMOBEL & 3,68 & 8,71 \\
\hline CABUÇU & 8,34 & 19,70 \\
\hline
\end{tabular}

Quadro 4.2 - Área das sub-bacias formadoras da bacia do Cabuçu (BARROS, 2004)

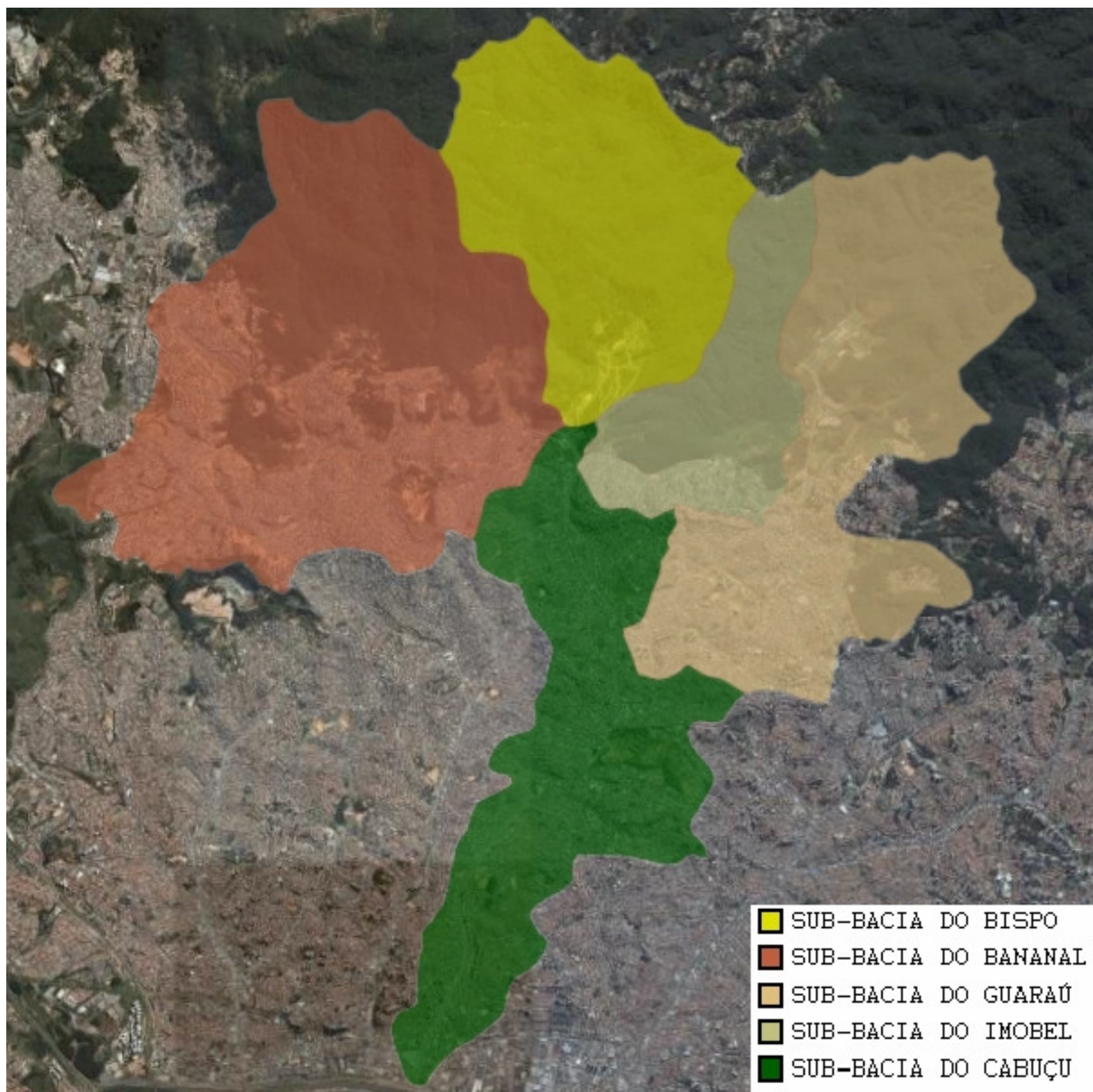

Figura 4.2 - Área de estudos: Bacia do Córrego Cabuçu e suas sub-bacias (BARROS, 2004)

\subsubsection{Ocupação da Bacia}

A bacia do Cabuçu pode ser dividida, considerando as características de sua ocupação, em três grandes áreas:

\subsubsection{1. Área totalmente urbanizada}

Compreende a parte de jusante da bacia até o trecho médio-superior, na região que vai da sua foz até a margem do Córrego do Bispo e a margem direita do córrego do Bananal. 
Nesta área, a ocupação urbana está completamente consolidada. As casas são construídas em alvenaria, a malha viária está quase totalmente asfaltada e serviços públicos essenciais como luz, água, telefone e esgoto contemplam a região.

\subsubsection{2. Área em urbanização}

São, atualmente, as regiões localizadas nas cabeceiras dos Córregos do Bananal e Canivete, Jardim Vista Alegre e uma parte do empreendimento Imobel, além da margem esquerda do Córrego do Bispo e o trecho médio e de montante do Córrego do Guaraú.

As construções são precárias, geralmente construídas com restos de madeira ou com blocos, sem reboco, e com poucos serviços públicos. Chama atenção, também, a enorme densidade de construções, sem qualquer área livre entre elas e, a ligá-las, apenas vielas estreitas.

\subsubsection{3. Área em mata nativa}

Resta ainda uma pequena parte da bacia coberta por mata nativa, junto às encostas da Serra da Cantareira. Aparentemente essa região ainda não foi ocupada por estar separada da parte urbanizada pelos córregos e contar com uma topografia bastante desfavorável às construções.

A maior área preservada da bacia está no loteamento de alto padrão da Imobel, ainda sem nenhuma construção, que compreende a sub-bacia do Córrego Itaguaçu, situada também nas encostas da Cantareira. 


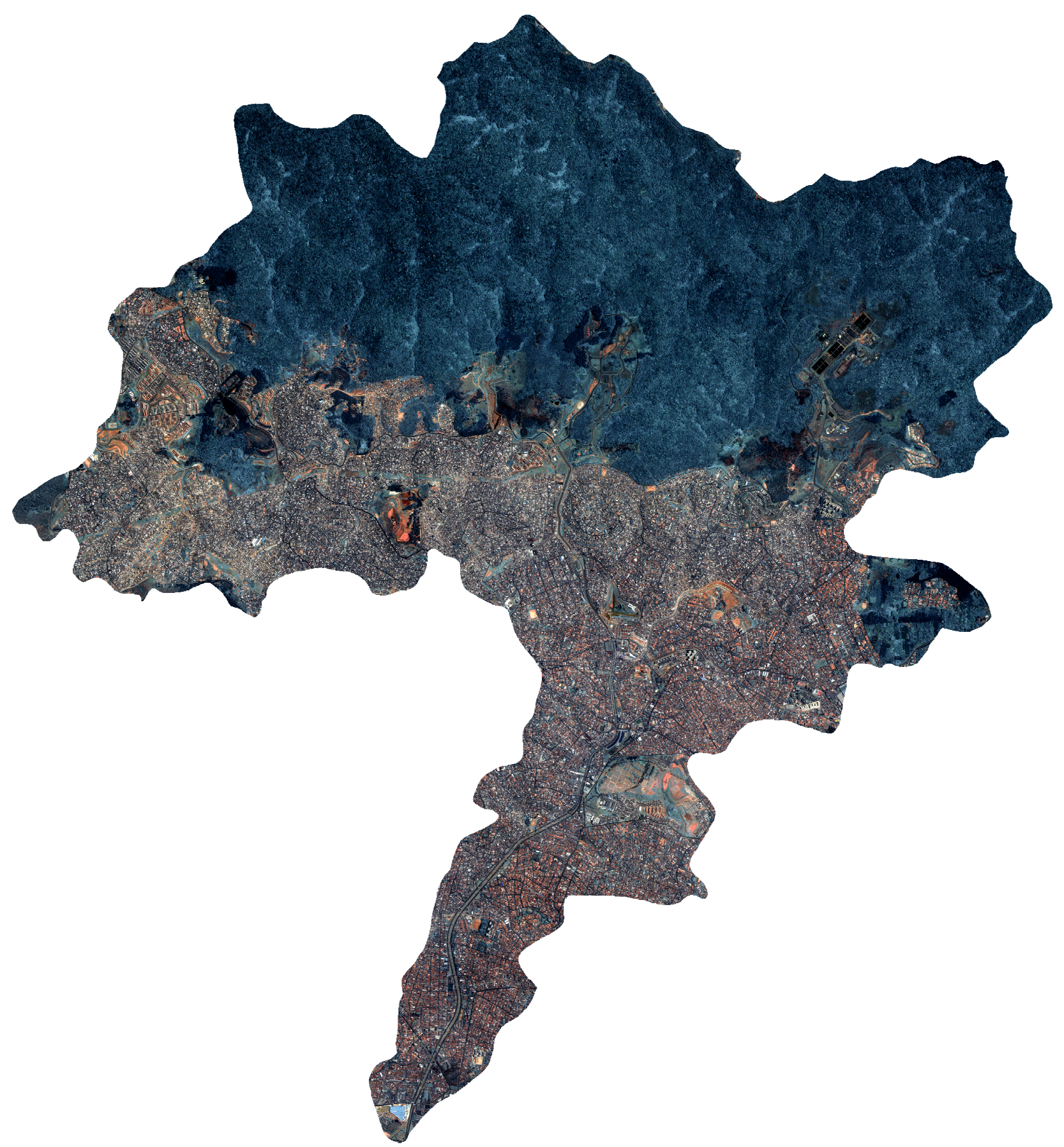

Figura 4.3 - Distribuição da ocupação humana na Bacia do Cabuçu de Baixo (IKONOS,2002) 


\subsection{Organização da Base de Dados Física}

Foram integrados dados materiais produzidos pela pesquisa "Gerenciamento Integrado de Bacias Hidrográficas em Áreas Urbanas" (BARROS, 2004), projeto este, também realizado na Bacia do Córrego Cabuçu de Baixo, além de dados provenientes do Atlas Ambiental do Município de São Paulo (ATLAS, 2002).

A estes planos de informação, foram acrescentados os seguintes temas: eixos de logradouros e quadras fiscais, obtidos de dados do programa SP Protege, da prefeitura do município de São Paulo; áreas de favelas e divisão espacial das subprefeituras, obtidos do trabalho "Base Cartográfica Digital das Favelas do Município de São Paulo" (CENTRO DE ESTUDOS DA METRÓPOLE, 2000); base de informações por setores censitários (IBGE, 2000), com informações sobre responsáveis, população, habitação e nível de instrução.

Foram também incluídos seguintes planos de informação: limite geográfico da Bacia Hidrográfica do Córrego Cabuçu de Baixo, limites geográficos de suas subbacias, curvas de nível com eqüidistância de 5 metros, pontos cotados, rede de drenagem hidrográfica retificada e atualizada, piscinões, mapa temático de uso do solo (com 26 classificações).

Todos os dados utilizados foram registrados para o sistema de coordenadas UTM (fuso 23, Datum Córrego Alegre) de forma a constituírem uma base compatível e facilitar a interpretação visual de dados da imagem com base nas referências espaciais das demais bases de dados. A resolução espacial de todos os mapas apresentados neste trabalho é de 2 metros.

Os mapas da base de dados georreferenciada foram gerados de acordo com o histórico a seguir, convertidos do formato vetorial para o formato raster, a fim de que pudessem ser processados pelo aplicativo VISTA/SAGA. São estes:

\begin{tabular}{|c|l|}
\hline Mapas & \multicolumn{1}{c|}{ Títulos } \\
\hline 01 & Carta de Uso do Solo e Cobertura Vegetal \\
02 & Carta de Declividades \\
03 & Carta de Hipsometria \\
04 & Carta de Geologia \\
05 & Carta de Geomorfologia \\
06 & Carta de Proximidades de Rede Viária \\
07 & Carta de Proximidades de Superfícies Líquidas \\
\hline
\end{tabular}

Quadro 4.3 - Mapas temáticos da área de estudo 


\subsubsection{Carta de Uso do Solo e Cobertura Vegetal}

Obtida a partir do "Projeto Cabuçu de Baixo" (BARROS, 2004) que atualizou, por meio de imagem Ikonos (2002) a carta original, na escala 1:10.000, oriunda da publicação "Vegetação Significativa do Município de São Paulo" (SECRETARIA DO VERDE E DO MEIO AMBIENTE, 1988) decorre de trabalho elaborado pela Secretaria de Planejamento da Prefeitura - Cadastramento dos Espaços Arborizados Significativos do Município de São Paulo - 1984-85, quando foram levantados, mapeados e identificados conjuntos e exemplares arbóreos significativos no município.

As cartas que recobrem a área da bacia foram escanerizadas $e$ posteriormente vetorizadas, gerando um arquivo digital que possibilitou o registro associado com a rede viária e com a imagem de satélite lkonos. Através de interpretação visual de dados foi possível avaliar a situação atual das áreas de vegetação significativa, indicadas nas cartas, em 1988.

O referido trabalho não teve como objetivo a realização de um cadastramento botânico detalhado, mas baseou-se em alguns critérios importantes quanto à seleção das ocorrências a realçar .

De acordo com SECRETARIA DO VERDE E DO MEIO AMBIENTE (1988), em princípio, foi dado ênfase ao reconhecimento da vegetação arbórea, visto ser esta categoria vegetal a que mais contribui tanto para a organização dos espaços na cidade, como para manutenção das condições ambientais. Nas áreas urbanizadas, os critérios foram os seguintes:

- a qualidade dos componentes vegetais;

- a extensão e a densidade do conjunto arborizado;

- o fato de constituir um testemunho da vegetação autóctone;

- a localização do conjunto na cidade e sua importância como ponto referencial e como "pausa" entre áreas densamente ocupadas;

- a carência de vegetação de porte no bairro;

- a tipologia da área em que a vegetação está inserida, seu grau de utilização e de fruição visual;

- sua contribuição para amenizar as condições ambientais. 


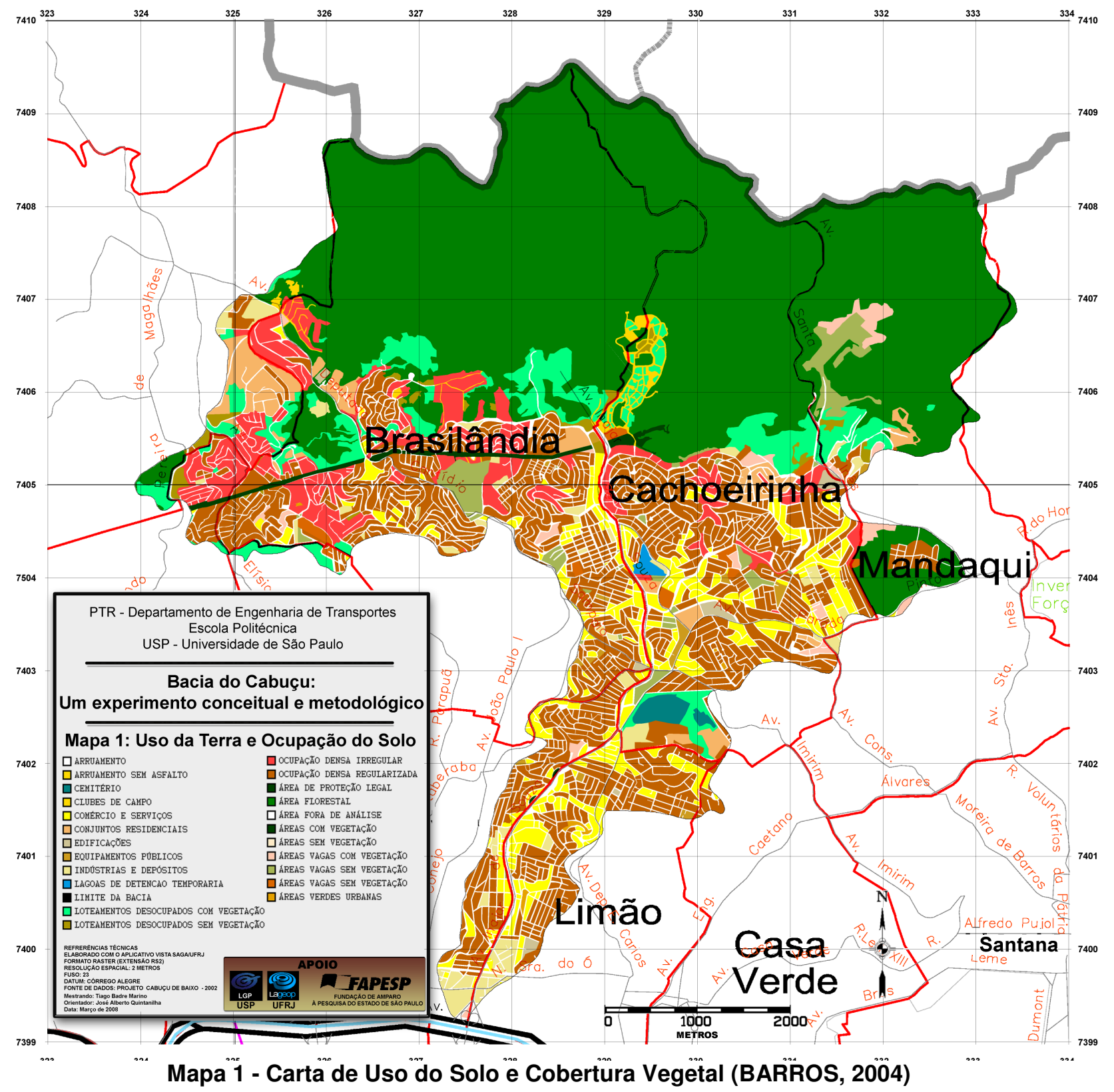




\subsubsection{Carta de Declividades}

Para a confecção da Carta de Declividades, empregaram-se os critérios:

- As classes escolhidas seguiram a legislação que controla a expansão urbana Lei № 6766 / 79. Esta Lei define que deve ser considerada não edificante a faixa acima de 47 por cento de declividade, e a faixa entre 30 e $47 \%$ só pode ser ocupada diante da apresentação de laudo geotécnico. Portanto, segundo o Quadro 4.4, definiram-se as seguintes classes:

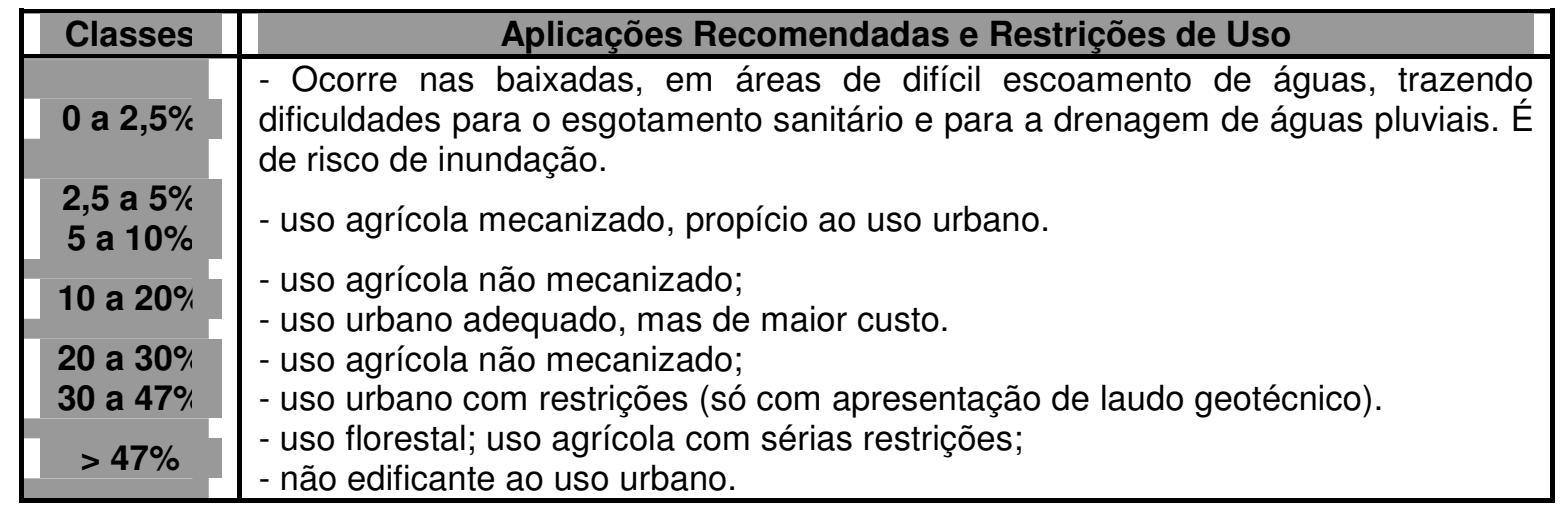

Quadro 4.4 - Classes de Declividades. Adaptado de MELO FILHO (2003)

- Após definidas as classes, utilizou-se o software Surfer 6, da Golden Software, convertendo-se o arquivo 2D com curvas de nível, obtido a partir dos arquivos originais formato DXF, em arquivo 3D, colocando-se cada curva de nível em sua respectiva cota verdadeira. As eqüidistâncias entre as curvas de nível foram de 10 metros, situadas entre as faixas de 715 metros até 1215 metros.

- Em seguida, utilizou-se o aplicativo Arc View 3.2, da ESRI para gerar-se um Modelo Digital do Terreno, do qual extraiu-se a Carta de Declividades. Esta carta foi transferida para o Sistema de Análise Geo-Ambiental - SAGA / UFRJ, salvando o modelo em formato TIFF. Assim, o arquivo em formato TIFF foi aberto no módulo CRIAR, do VISTA/SAGA. Por meio da execução da classificação automática através das cores indexadas do TIFF as classes de declividades foram auto-reconhecidas (uma cor para cada classe), necessitando apenas renomear as legendas que antes tinham nomes no padrão "cor 1", "cor 2 ",..,"cor n", para "0 a 0,5\%", “0,5 a 1,5\%”, e assim por diante, obtendo assim o mapa no formato Raster/Saga (rs2). 


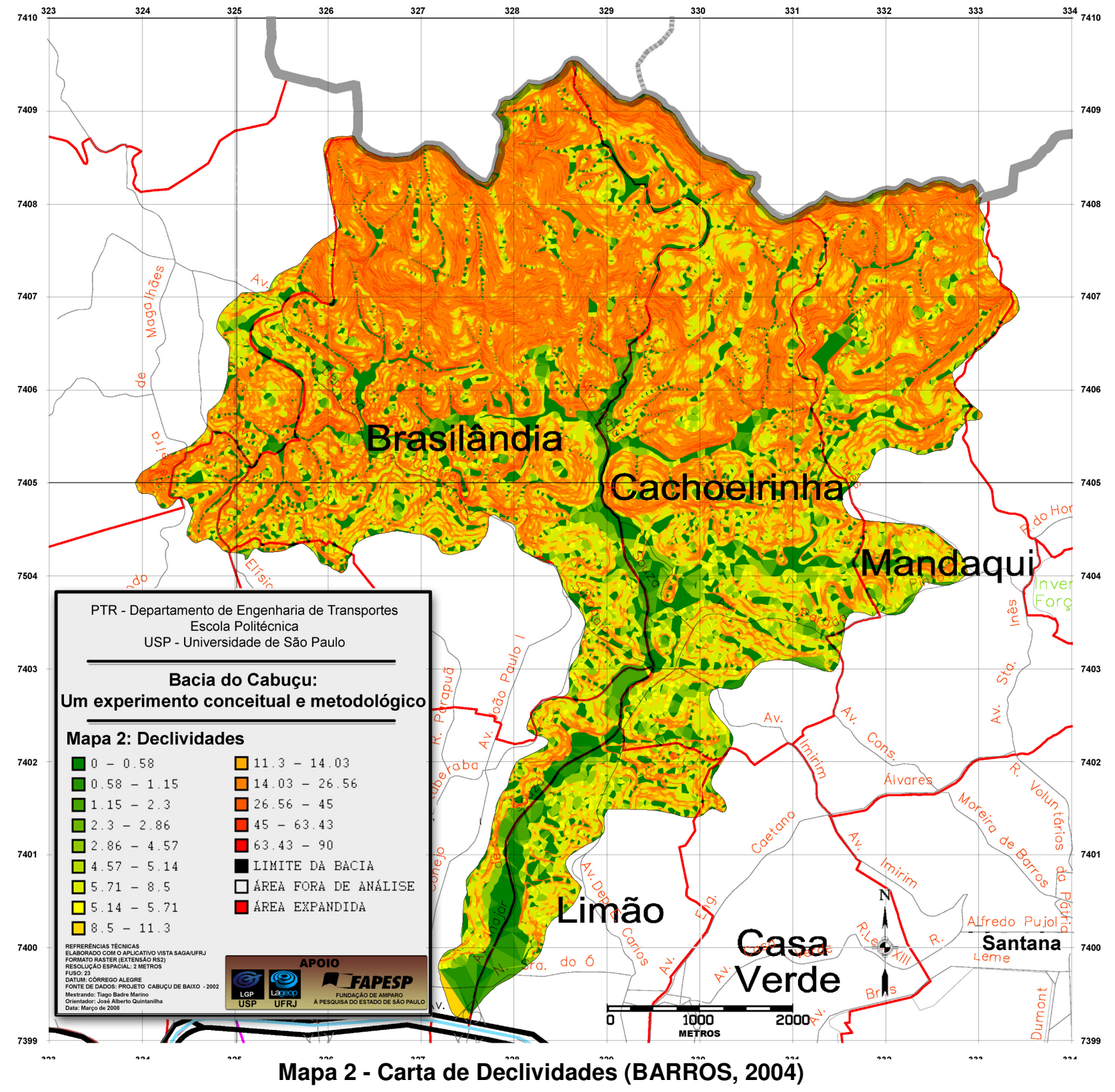




\subsubsection{Carta de Faixas Altimétricas}

O mapa foi obtido em formato digital vetorial de extensão DGN. Foi então processado no aplicativo Arc View onde, para cada faixa de cota altimétrica foi atribuída uma cor. Em seguida o projeto foi salvo em formato TIFF, aberto no aplicativo VISTA/SAGA e, no módulo CRIAR, as cores de cada cota foram autoreconhecidas. Restou então somente a tarefa de renomear as classes.

As faixas de 10 metros entre cotas altimétricas consecutivas são satisfatórias, uma vez que a variação entre cotas adjacentes inferior a 10 metros não influencia significativamente no aumento da probabilidade dos riscos analisados. A decisão também foi apoiada na apreciação de MELHO FILHO (2003).

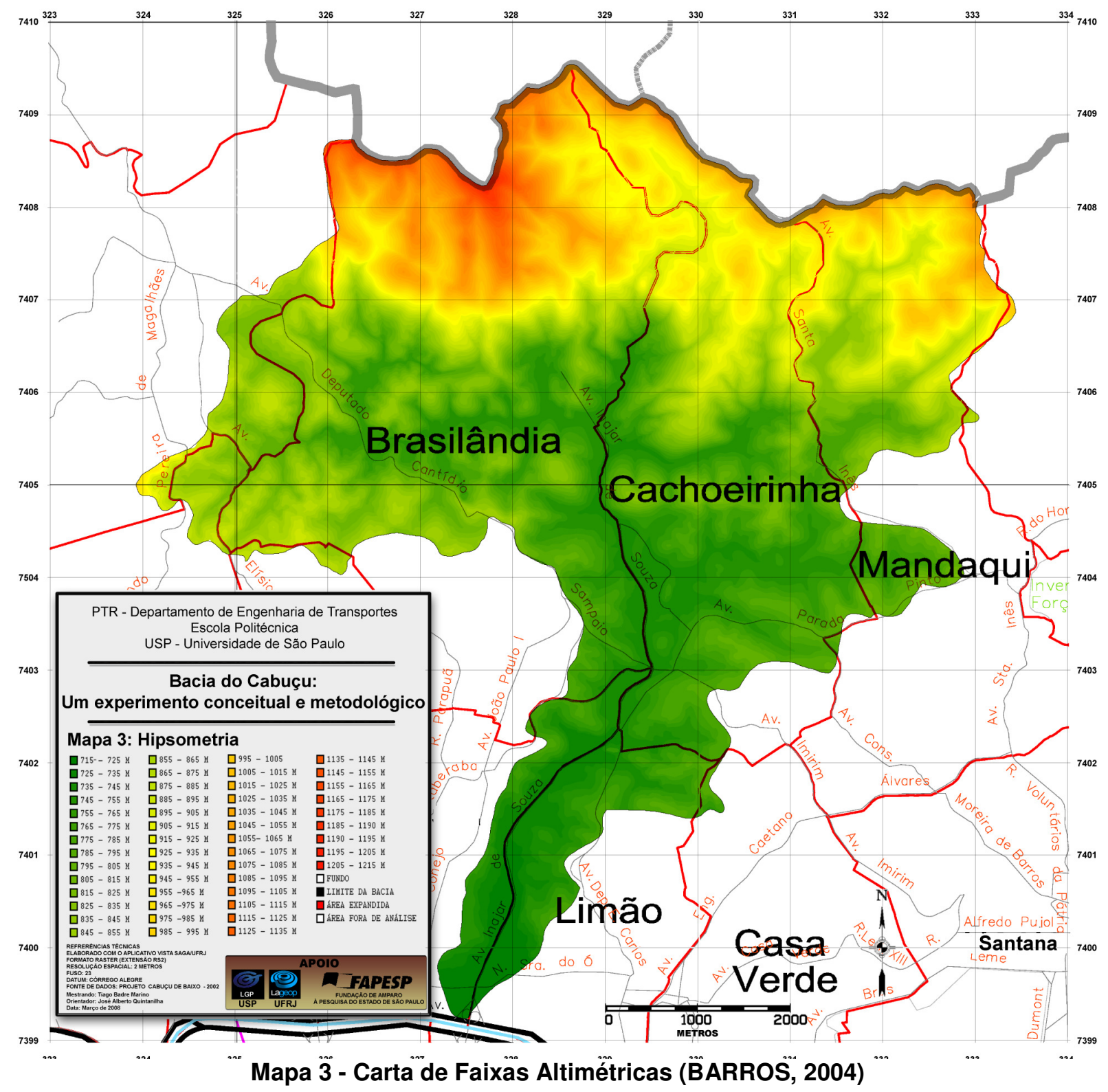




\subsubsection{Carta de Geologia}

Com apenas quatro classificações geológicas, a carta de geologia foi obtida a partir da base de dados do "Projeto Cabuçu de Baixo" (BARROS, 2004), em formato vetorial, restando apenas a tarefa de conversão para o formato Raster/SAGA.

Para tanto foi gerado um arquivo intermediário, de formato TIFF com cores indexadas, a partir do aplicativo Arc View 3.2. Isto permitiu que o mapa preservasse a proporção de uma cor para cada classe, restando apenas a tarefa de autoclassificação, no aplicativo VISTA/SAGA. Como resultado, para cada cor do mapa, foi criada uma classe, posteriormente renomeada de acordo com a característica geológica representada pela mesma.

As unidades geológicas presentes na área de estudo e sua descrição sucinta foram objeto da consulta ao Atlas Ambiental do Município de São Paulo (2003), extraídas de RODRIGUEZ (1998) e PELOGGIA (1998) e são assim caracterizadas:

\section{Sedimentos Terciário-quaternários:}

- Formação São Paulo composta por depósitos de sedimentos aluviais;

- Formação Resende composta por um sistema de leques associados à planície de rios entrelaçados, caracterizados por lamitos, arenitos e conglomerados.

Suítes graníticas indiferenciadas: compostas essencialmente por granitos, granodioritos, monzogranitos e granitóides indiferenciados, equigranulares ou porfiróides em parte gnáissicos, de caráter sintectônico e pós tectônico, que ocorrem predominantemente na região norte do município de São Paulo, sustentando a Serra da Cantareira.

Grupo São Roque e Grupo Serra do Itaberaba: formados por dois grupos litoestratigráficos, onde ocorrem metassedimentos de natureza diversificada e metavulcânicas básicas:

- PCSIq - sedimentos clastoquímicos compostos por metassiltito arcoseano, metarcóseo, metagrawacas, metassiltitos, quartzitos, quartzitos feldspáticos e metaconglomerados;

- PCSRi - micaxistos, anfibolitos, metacalcários e rochas calciossilicáticas do Grupo S. Roque indiferenciado. 


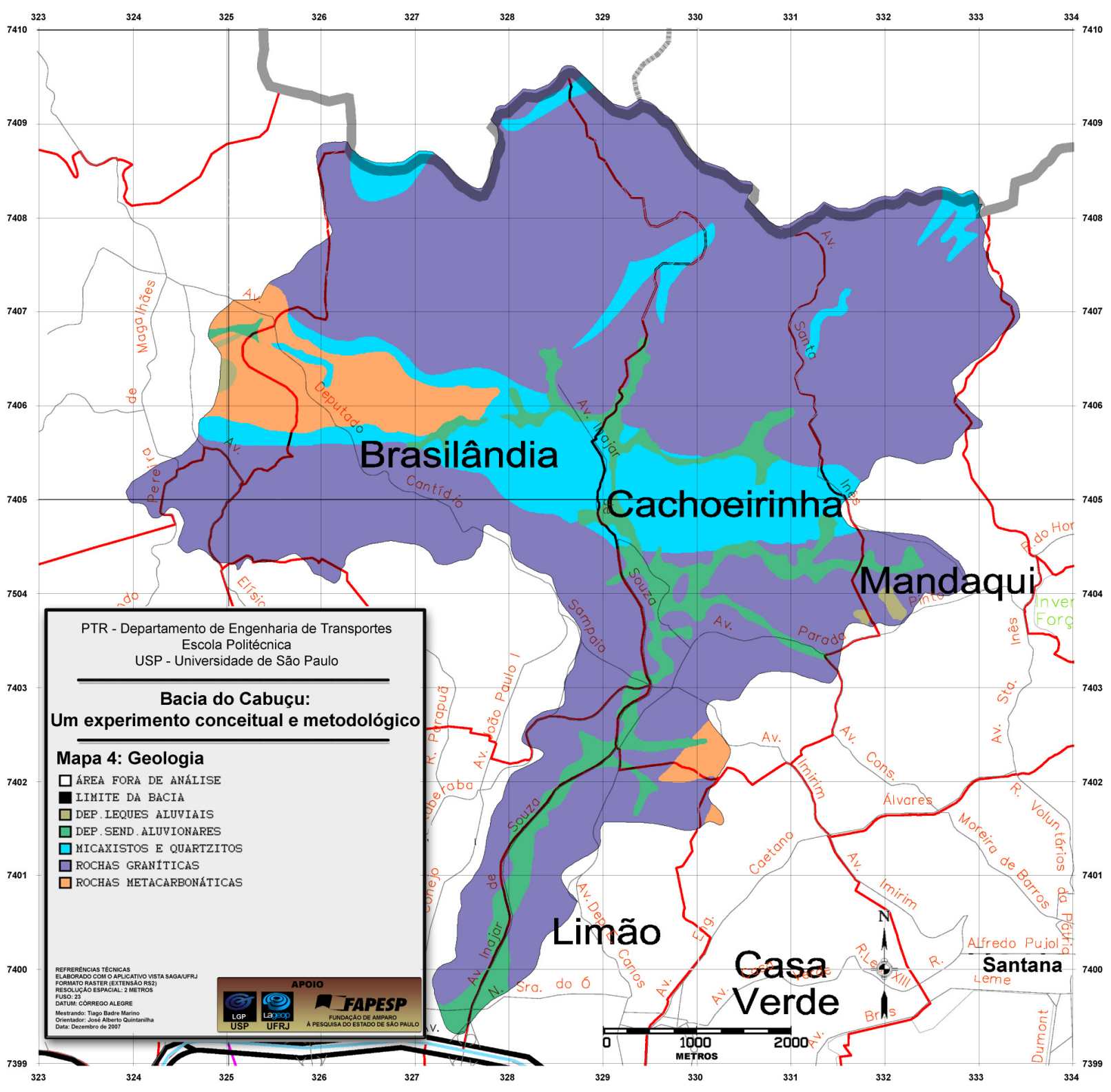

Mapa 4 - Carta de Geologia (BARROS, 2004) 


\subsubsection{Carta de Geomorfologia}

No contexto geomorfológico regional, a área de estudo está inserida no Planalto Atlântico, mais especificamente no Planalto Paulistano (PONÇANO, 1981).

O mapa geomorfológico foi incorporado a partir de dados do Projeto Geprocav - Plano de Gestão de Risco de Enchentes, executado pela Engecorps-MKR. Para dar consistência a estes dados, foi necessária além da conversão das informações originalmente disponibilizadas em MapInfo (formatos DAT e TAB), a verificação e adequação das unidades de modo a terem coerência com dados topográficos, hidrográficos e geológicos.

As unidades geomorfológicas que ocorrem na área são:

Colinas pequenas: caracterizadas pela predominância de interflúvios sem orientação, com área inferior a $1 \mathrm{~km}^{2}$, topos aplainados a arredondados, vertentes ravinadas com perfis convexos a retilíneos. Apresenta ainda drenagem de baixa a média densidade, padrão subparalelo a dendrítico, vales fechados e planícies aluvionares interiores restritas.

Morros: caracterizados pela presença de topos arredondados, vertentes com perfis convexos a retilíneos, drenagem de alta densidade, padrão dendrítico a retangular, vales abertos, planícies aluvionares interiores desenvolvidas. Em geral constitui um conjunto de formas em meia laranja.

Morros e montanhas: caracterizados pela presença de serras alongadas, de topos angulosos, vertentes ravinadas com perfis retilíneos, às vezes abruptos. Presença de drenagem de alta densidade, padrão paralelo e vales fechados.

Planícies aluviais: caracterizadas por terrenos baixos e mais ou menos planos junto às margens dos rios, sendo áreas sujeitas a processos de inundações.

Setores de encostas íngrimes: caracterizadas por encostas retilíneas, com ângulos de declividade maiores do que 15\% e amplitudes locais entre 100 e 300m. Presença de drenagem de alta densidade, padrão paralelo a retilíneo e vales fechados.

A análise do mapa geológico, em conjunto com o mapa geomorfológico e com a carta de declividade, além de trabalhos de campo, permite definir áreas com potencial a erosão, escorregamentos e demais processos de risco geológico. 


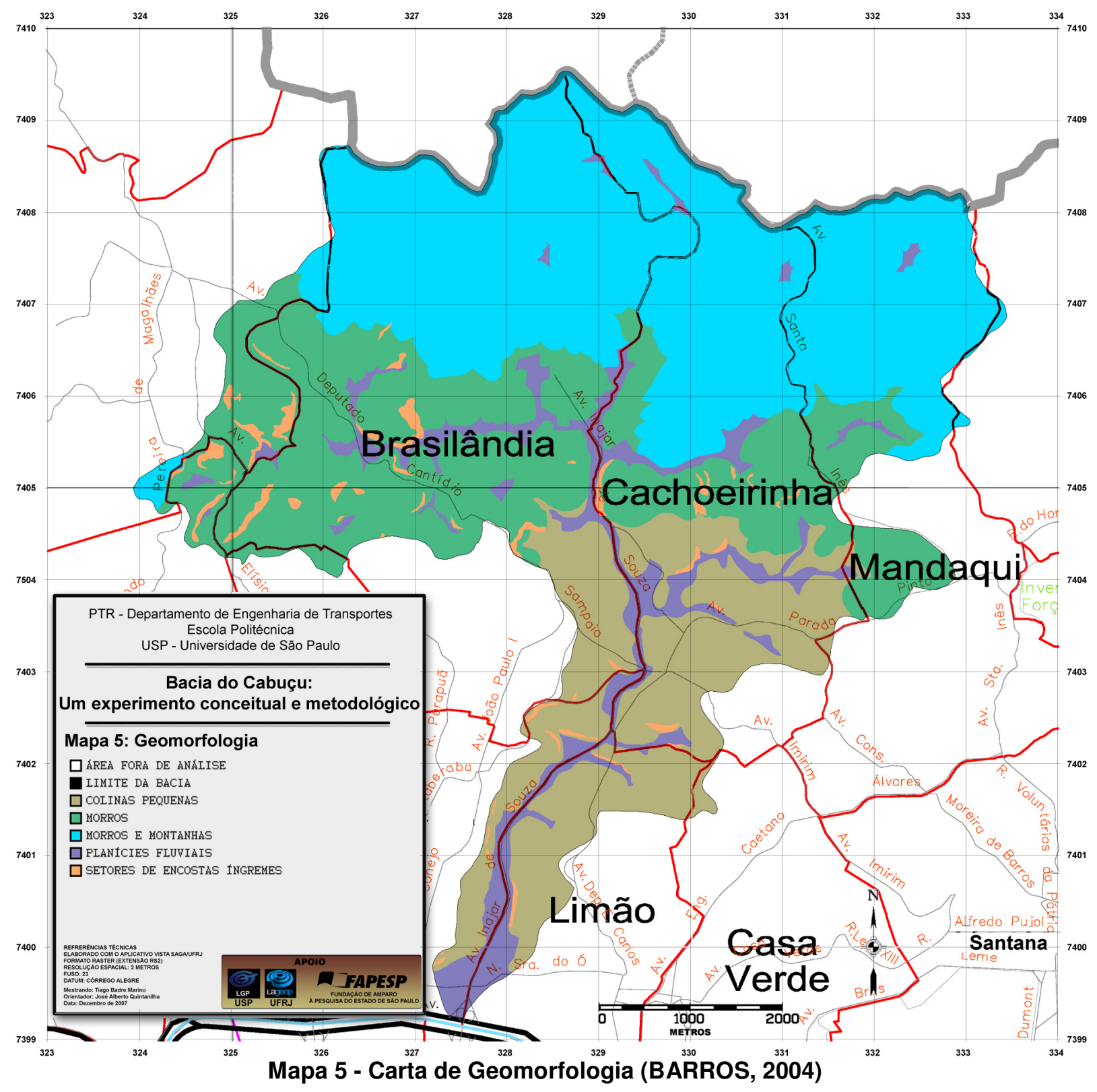




\subsubsection{Carta de Proximidades de Rede Viária}

No que diz respeito aos riscos de enchentes, a presença de arruamentos provoca o espraiamento das áreas próximas às vias, criando patamares de deposição, além de aumentar a velocidade de escoamento das águas decorrentes das chuvas. Outro fator agravante é o fato das estradas e ruas apresentarem o sistema de escoamento das águas pluviais precário, decorrente do entulhamento de bueiros e tubulação.

Quanto à "contribuição" para a ocorrência de deslizamentos, ocorrem descalçamentos de taludes e desvio do escoamento superficial, provocando infiltrações localizadas, indutoras de intemperização acentuada em porções diferentes da encosta, o que pode conduzir a tensões internas que levam à ruptura da geometria da encosta (formação de cicatrizes de desmoronamentos e deslizamentos) (XAVIER DA SILVA, 2007). 


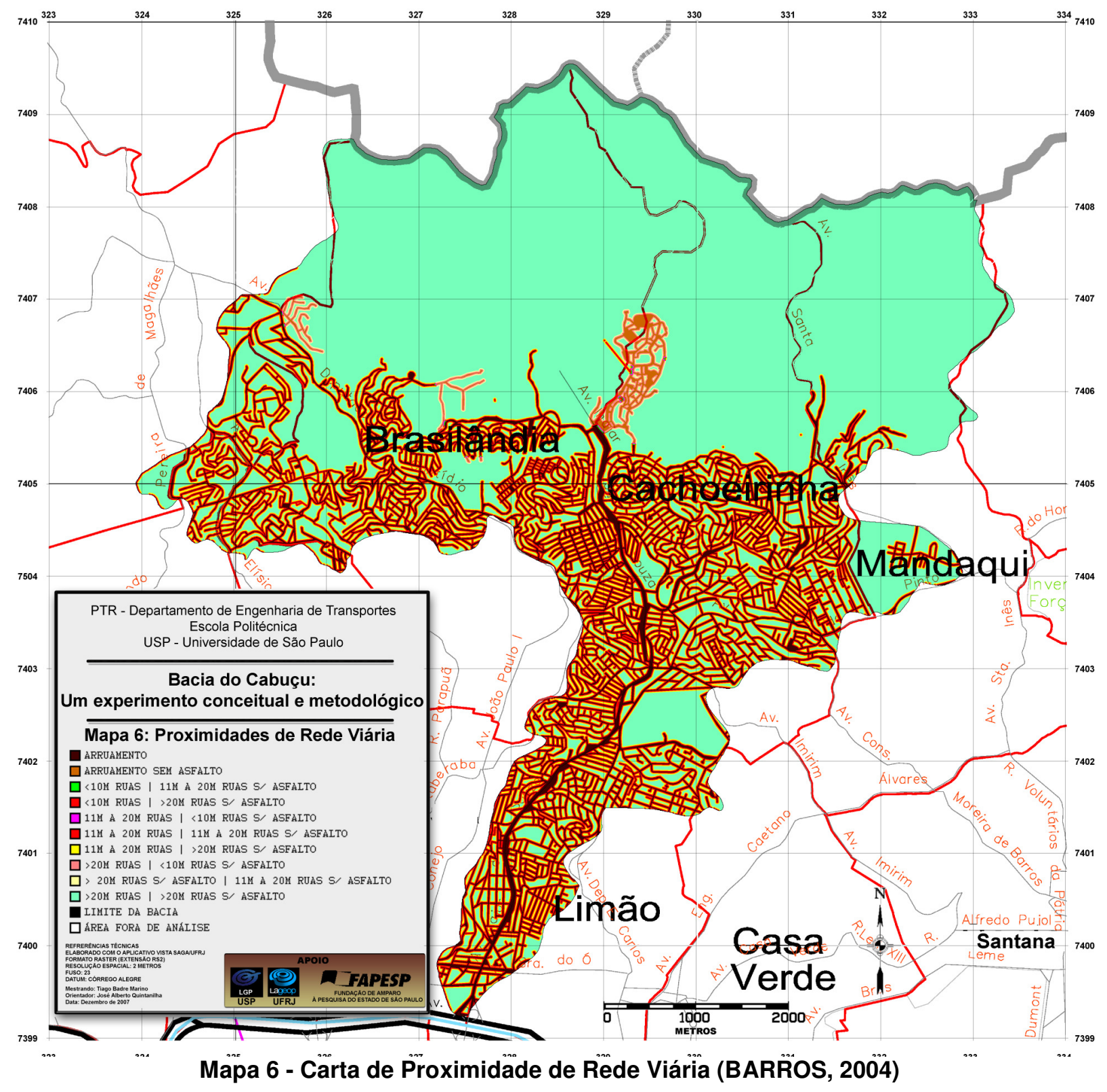

\subsubsection{Carta de Proximidade de Superfícies Líquidas}

A carta de Proximidades de Superfícies Líquidas é um parâmetro bastante importante uma vez que a medida que se aproxima destas, maior a probabilidade de ocorrência de enchentes, agravados pela presença de assentamentos irregularmente instalados.

Grande parte da área atualmente urbanizada na região se encontra às margens do Córrego Cabuçu de Baixo e seus afluentes, locais classificados por altíssimo risco de inundação, em função das facilidades que o meio provê no processo de instalação destas moradias sem infra-estrutura alguma. Utilizam a água dos rios para consumo próprio, depositando seus detritos nestas mesmas fontes. $O$ 
assoreamento causado pela ocupação desordenada ao longo das calhas dos rios eleva potencialmente a o risco de enchentes nestas áreas.

Portanto, foi criado o mapa de proximidades, definindo-se buffers de distâncias das superfícies líquidas.

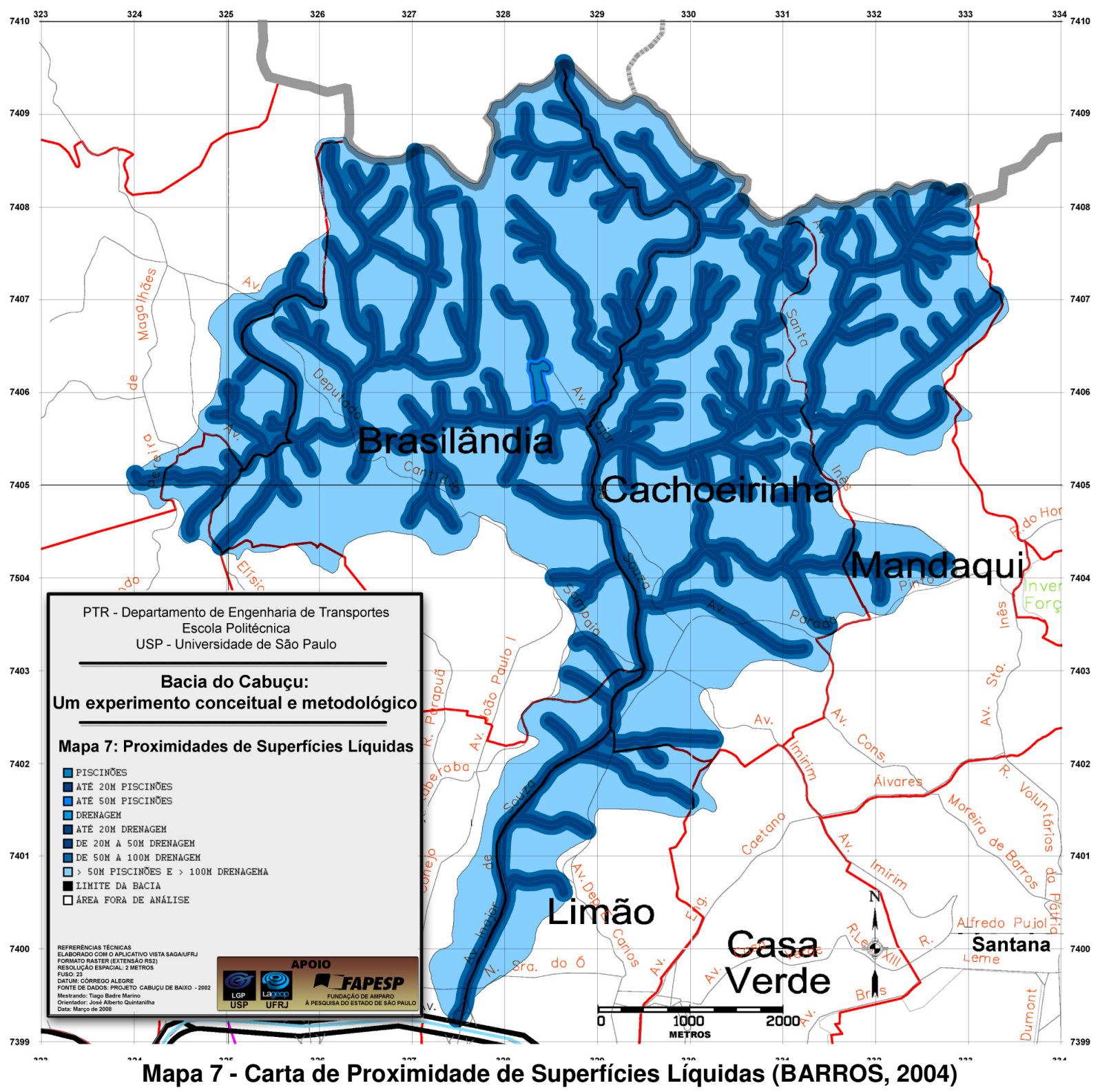




\subsection{Organização da Base de Dados Sócio Econômica}

Os procedimentos metodológicos para a elaboração das bases cartográficas da Região da bacia do Cabuçu, tanto do ambiente físico, como da caracterização ambiental da população, seguiram caminhos distintos, proporcionados pelo geoprocessamento.

Para a concepção da base de dados da geografia humana, a origem e o formato dos dados foram únicos, exclusivamente apoiada nos resultados do Censo 2000 (IBGE, 2002) no nível de detalhe proporcionado pelos setores censitários.

As análises ambientais da população residente na área de estudos versaram sobre três principais dimensões, cada uma delas com seu conjunto de variáveis, empregadas convencionalmente para a detecção dos índices de desenvolvimento humano e de qualidade de vida. Desta forma, foram desenvolvidos mapas temáticos sobre condições de infra-estrutura, caracterizadas pelas contribuições do estado e do indivíduo para a qualidade de vida, correspondentes aos cuidados com o saneamento básico, como condições do domicílio quanto à água canalizada, coleta de lixo por serviço de limpeza, ligação à rede de esgotos e domicílios com banheiro exclusivo; sobre condições sociais e herança cultural, como número de habitantes por domicílio, níveis de escolaridade, identificação de analfabetismo; e das condições de renda, com dados cartográficos sobre classes de renda, bem como as condições de renda mínima e renda máxima.

\subsubsection{Unidade territorial: Setor censitário}

A unidade territorial adotada para as análises referentes à população é o setor censitário, conforme delimitado e identificado por IBGE (2002). A partir dos dados originais contidos nas planilhas, elaborou-se toda a base de dados georreferenciada, de estrutura matricial, apropriada para as análises a serem realizadas no ambiente do sistema SAGA.

A região de estudo abrange o total de 442 setores censitários, os quais variam enormemente em superfície, como podemos observar no Mapa 8. As áreas de maior concentração de ocupação humana apresentam-se mais fragmentadas, em essência, na porção inferior da bacia, enquanto o setor norte, predominantemente coberto por mata nativa, de baixíssima concentração humana, apresenta setores com grande porção territorial. 
Convém observar que não há dados coletados pelo IBGE para os setores censitários localizados no setor norte da área de estudo. Nas planilhas de dados disponibilizadas pelo Instituto estes setores apresentam valores nulos para todos os campos de informações. Este fato justifica a ausência de resultados nas análises de Qualidade de Vida, baseadas em dados censitários do IBGE. Trata-se de região da Serra da Cantareira, onde de fato não ocorreu processo de antropização.

De qualquer forma este fato não prejudicará o resultado dos estudos pois, apesar de risco eventualmente ocorrer, não há vidas humanas envolvidas.

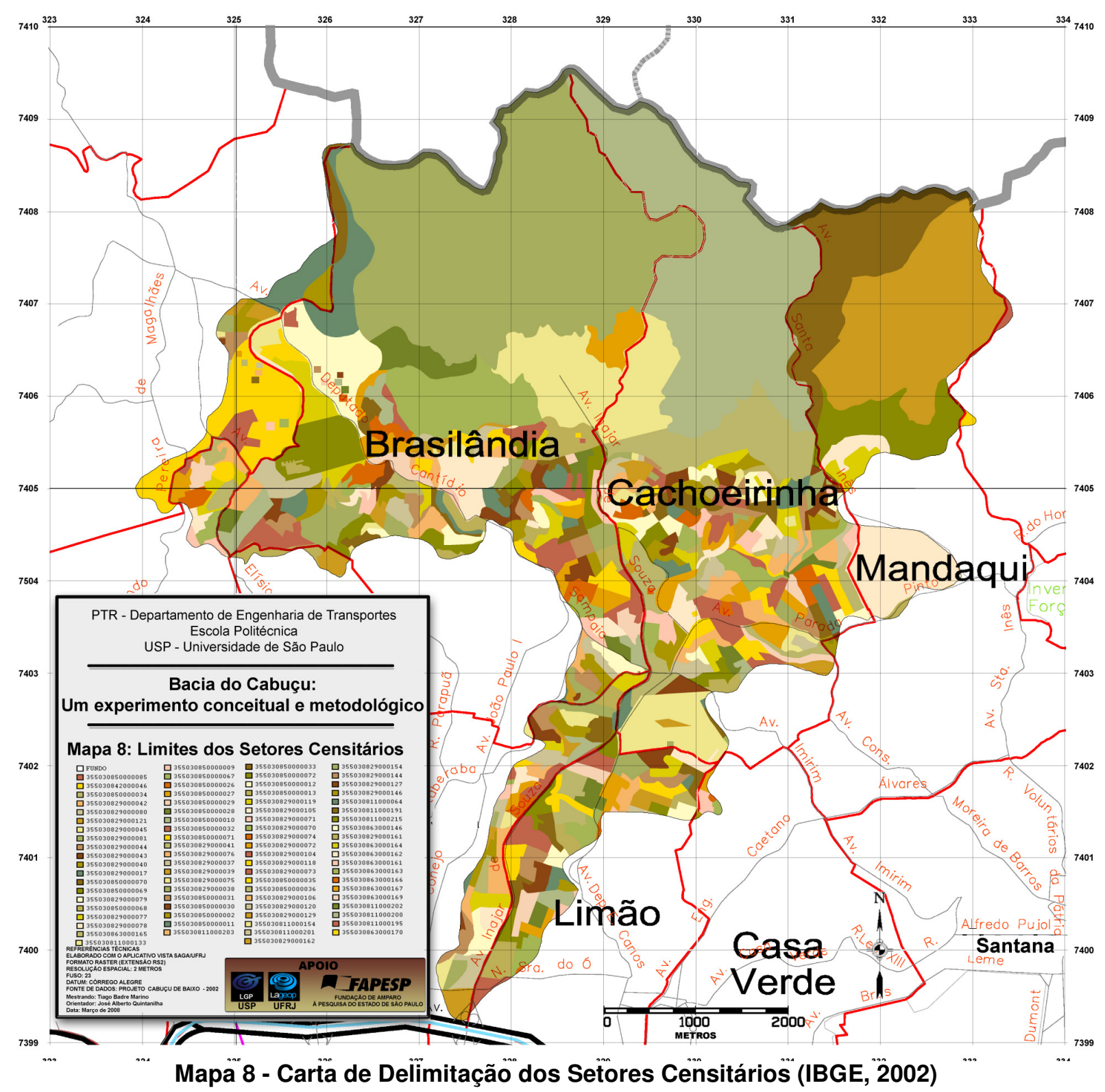

A base de dados cadastrais da população, em escala dos setores censitários, resultado do Censo 2000, foi disponibilizada pelo IBGE em 2002, estruturada em quatro dimensões, a saber: Domicílios, Pessoas, Instrução e Responsáveis. 
Nesse ano, o IBGE apresentou também o programa computacional ESTATCART - Sistema de Recuperação de Informações Georreferenciadas (IBGE², 2002), pelo qual podem-se efetuar consultas e visualizar as informações, que anteriormente àquela data eram fornecidas apenas na forma tabular. Assim, o IBGE dá mostras de importante evolução na área do Geoprocessamento, para atender à crescente procura de informações estatísticas e geográficas em escala municipal ou em escala dos setores censitários. Com a aplicação do ESTATCART, foram realizadas as preliminares análises exploratórias dos dados, com o mapeamento de estatísticas.

A permitir aquela visualização, os arquivos disponibilizados em IBGE (2002) estão nos seguintes formatos: SHP, SHX, SBN, SBX e DBF, constituindo este último os valores tabulares.

A geração de toda a base georreferenciada para este trabalho, no trato dos dados populacionais, foi desenvolvida com utilização da ferramenta de criação de mapas temáticos, disponível no módulo "VISUALIZAÇÃO", do aplicativo VISTA/SAGA.

Primeiramente realizou-se a conversão da malha de setores censitários do formato shape (shp) para o formato matricial Raster/Saga (rs2), por meio do "Conversor SHP $\rightarrow$ RS2", aplicativo desenvolvido e disponibilizado pelo LAGEOP/UFRJ.

Em segunda etapa, as tabelas originais para o município de São Paulo, de Domicílios, Pessoas, Instrução e Responsáveis, foram filtradas para a área de estudo, pela seleção daqueles setores censitários. Todas as planilhas DBF que, antes apresentavam aproximadamente 13 mil registros, referente a todos os setores censitários da Cidade de São Paulo, passa a ter apenas 442 registros, referentes apenas aos setores cobertos pela bacia do Cabuçu. Este processamento se faz necessário visando otimizar o desempenho do módulo de criação de mapas temáticos do VISTA/SAGA, reduzindo assim o tempo de processamento do mesmo. A filtragem de dados foi realizada por meio da ferramenta "Filtrar dados de tabelas", também disponível no aplicativo VISTA/SAGA.

Tendo em vista que as tabelas originais do IBGE, de formato DBF, trazem o cabeçalho (nomes dos campos) em código no formato V0001, V0002,...V2500, pois são elaboradas especificamente para o uso no ambiente ESTATCART e sendo inviável descrever o significado de cada campo em seu título, o IBGE os codifica nos 
arquivos e disponibiliza um manual descritivo de cada uma das variáveis por meio do um documento denominado "Censo Demográfico 2000” (IBGE², 2002).

Sendo assim, houve também um trabalho de leitura do referido manual a fim de localizar os códigos das variáveis necessárias a este projeto, dentre as mais de 3000 disponibilizadas pelo Censo.

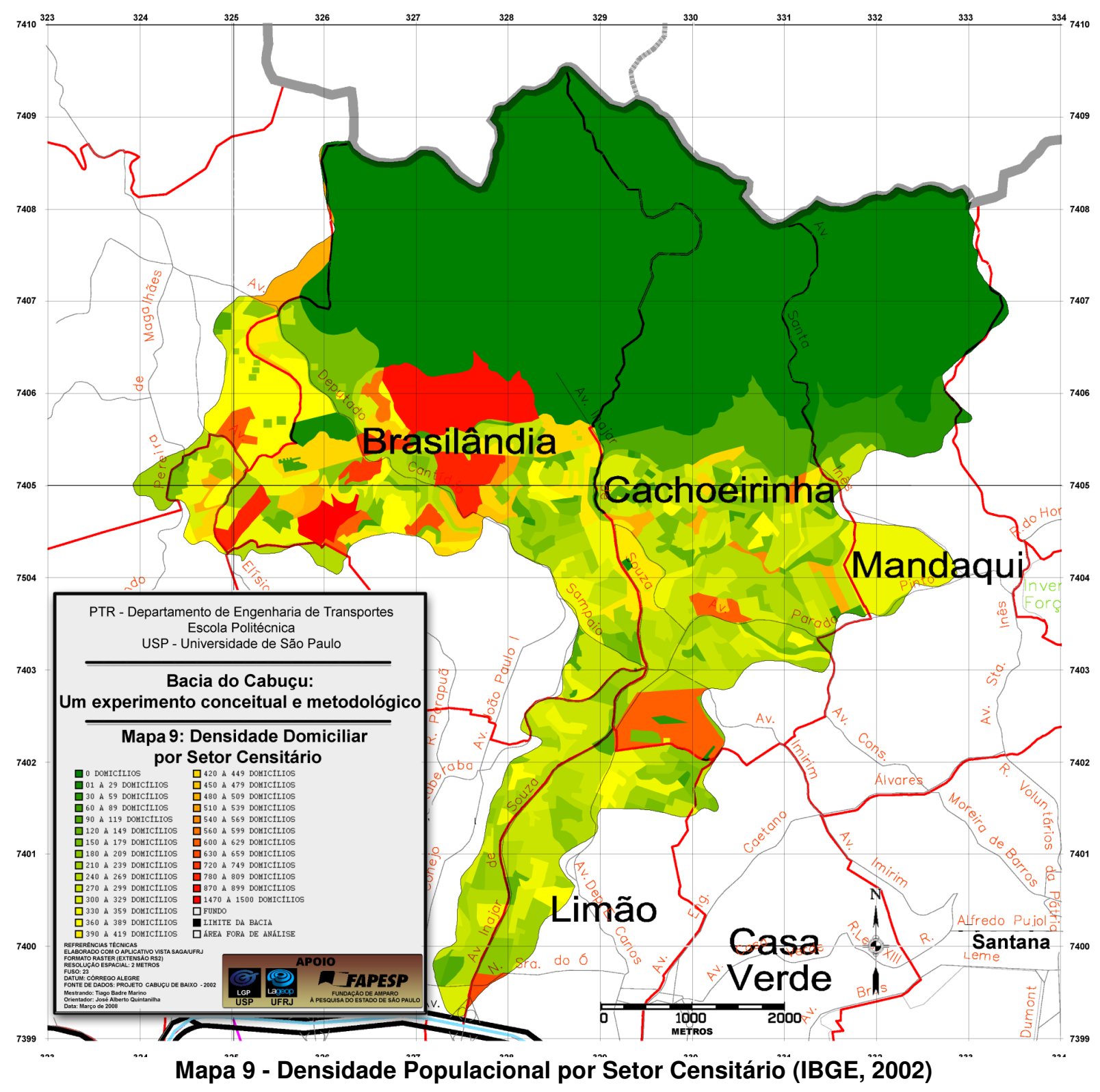

\subsubsection{Infra-estrutura básica do Estado e do indivíduo à qualidade de vida}

Conforme metodologia explicitada no organograma da Figura 3.10 no subcapítulo 3.3.4, a dimensão que expressa a infra-estrutura básica analisada compreende as variáveis que registram as contribuições que se espera do estado para a qualidade de vida da população, e também da contribuição que se deve aguardar dos habitantes do lugar. 
A responsabilidade pela proteção do meio ambiente, pelo combate à poluição e pela oferta de saneamento básico a todos os cidadãos brasileiros está consignada na Constituição Federal, e permite que os municípios possam legislar a respeito de assuntos de interesses locais e sobre a organização dos serviços públicos. É, portanto, uma atribuição do estado o abastecimento adequado de água, o esgotamento sanitário canalizado e a gestão da limpeza urbana e dos resíduos sólidos gerados em seu território.

As informações que constam do questionário sobre o abastecimento de água na Pesquisa Nacional de Saneamento Básico - PNSB 2000 (IBGE ${ }^{3}$, 2002) revelam aspectos relevantes para a qualidade de vida da população envolvida. O abastecimento de água é uma questão essencial para as populações e fundamental a ser resolvida, pelo estado e pelas comunidades, pelos riscos que sua ausência ou seu fornecimento inadequado podem causar à saúde pública (IBGE $\left.{ }^{3}, 2002\right)$. $O$ Censo 2000 revela que $77,8 \%$ dos domicílios particulares permanentes ocupados do Brasil dispõem de serviço de abastecimento de água por rede geral. Para os domicílios em geral a média brasileira é de $63,9 \%$, enquanto que a região sudeste, a mais bem atendida, dispõe de $70,5 \%$ de domicílios abastecidos. Por estes números, percebe-se que o débito do estado neste particular é muito grande.

A inexistência de abastecimento de água corrente, assim como a de uma adequada rede geral de esgoto, compromete 0 meio ambiente e, conseqüentemente, a saúde da população que utiliza rios, lagos, lagoas e solo contaminados por esgoto lançado in natura.

Para a qualidade de vida da população e de ambiente saudável na unidade domiciliar, há a necessidade fundamental da participação efetiva da população em transformar as contribuições proporcionadas pelo estado em concreto benefício.

De pouca valia há para uma família se, apesar do esforço do estado em propiciar condições básicas de saneamento, seus membros não realizarem o que é sua atribuição mínima, como a instalação de banheiro com sanitário, e ligá-los à rede pública, que é justamente a variável correspondente à contribuição individual à qualidade de vida. 


\subsubsection{Domicílios com abastecimento de água canalizada}

Considera-se nesta variável a porcentagem dos domicílios que são abastecidos por água e ligados à rede geral, e que têm pelo menos um ponto de água canalizada no interior do domicílio em cada setor censitário. Foram os seguintes os dados obtidos na classificação segundo o método de classificação por Quebras Naturais, expressos no mapa a seguir:

\begin{tabular}{|c|l|}
\hline \multicolumn{2}{|c|}{ PLANILHA DOMICÍLIOS.DBF } \\
\hline CÓDIG ) & \multicolumn{1}{c|}{ DESCRIÇÂA } \\
\hline V05 & Domicílios particulares permanentes \\
\hline V17 & $\begin{array}{l}\text { Domicílios particulares permanentes com abastecimento de água da rede } \\
\text { geral }\end{array}$ \\
\hline
\end{tabular}

Quadro 4.5 - Variáveis para classificação de "Domicílios com abastecimento de água canalizada" (IBGE, 2002)

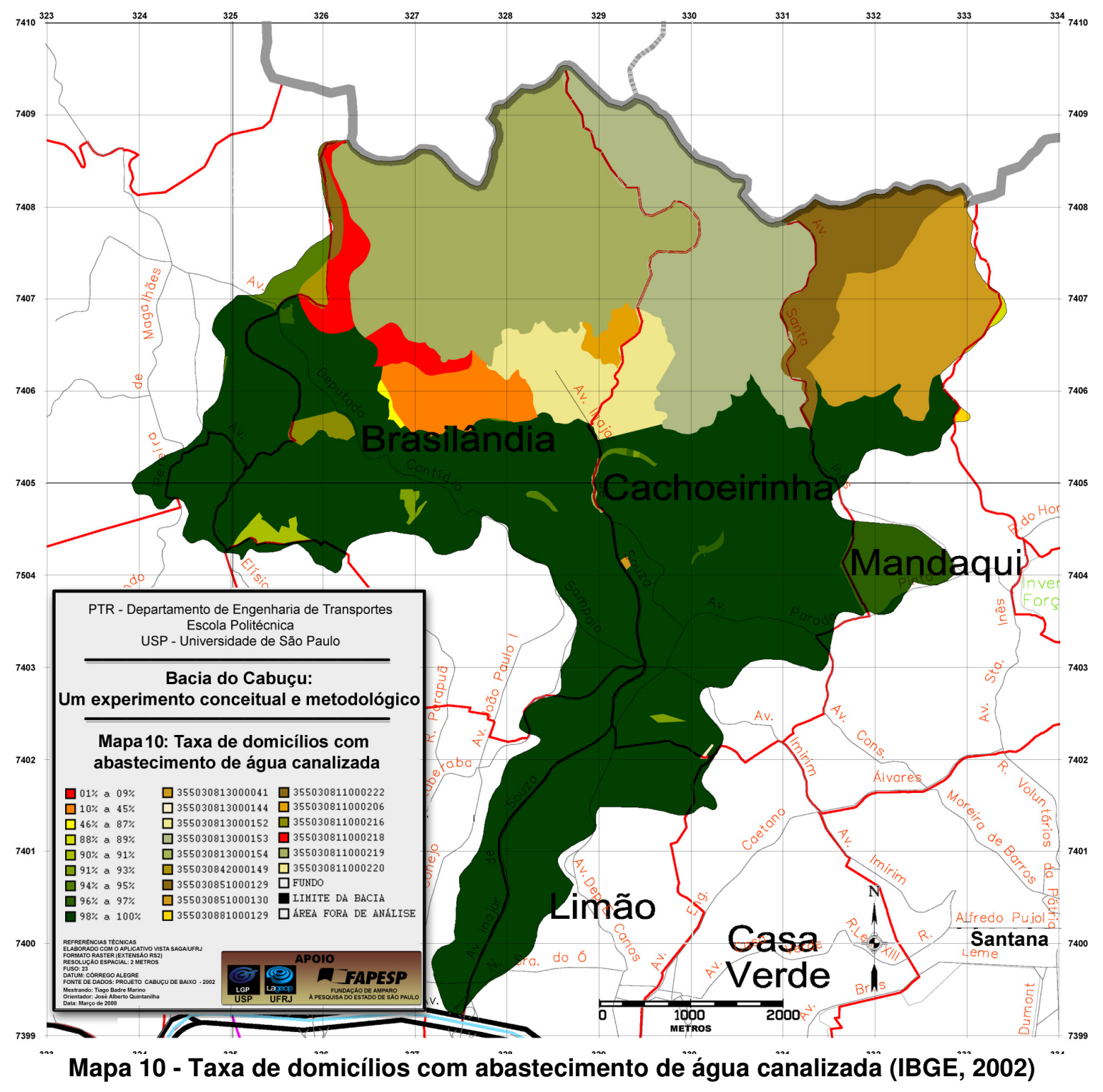




\subsubsection{Domicílios com coleta de lixo por serviço de limpeza}

Considera-se nesta variável a porcentagem dos domicílios que são atendidos por serviço de limpeza na coleta de lixo. Foram os seguintes os dados obtidos na classificação, que seguem expressos no mapa a seguir:

\begin{tabular}{|c|l|}
\hline \multicolumn{2}{|c|}{ PLANILHA DOMICÍLIO.DBF } \\
\hline CÓDIG ) & \multicolumn{1}{c|}{ DESCRIÇÃO } \\
\hline V05 & Domicílios particulares permanentes \\
\hline V40 & $\begin{array}{l}\text { Domicílios particulares permanentes com lixo coletado por serviço de } \\
\text { limpeza }\end{array}$ \\
\hline
\end{tabular}

Quadro 4.6 - Variáveis para classificação de "Domicílios com coleta de lixo" (IBGE,2002)

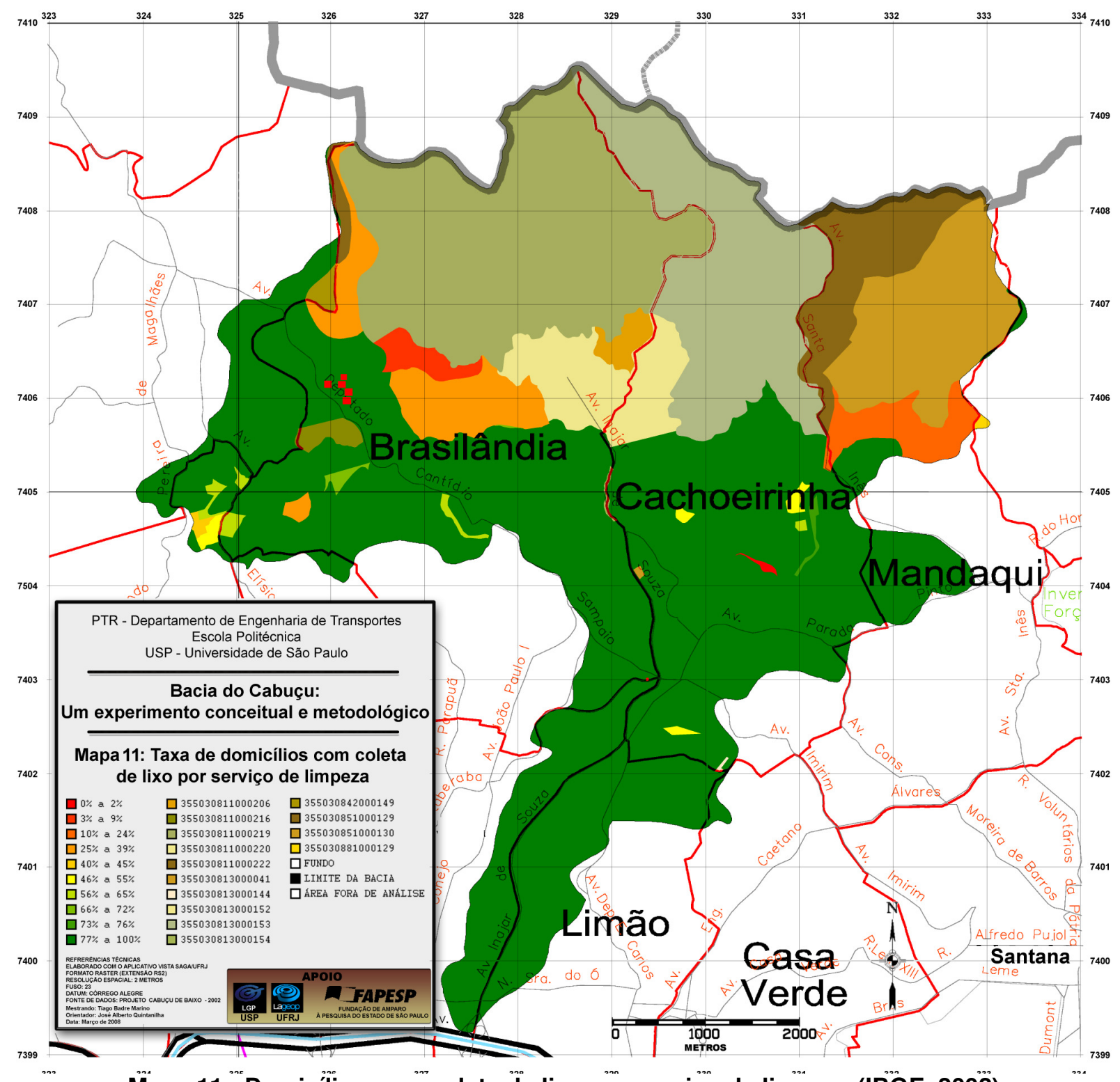

Mapa 11 -"Domicílios com coleta de lixo pôr serviço de limpeza (IBGE, 2002) 


\subsubsection{Domicílios conectados à rede de esgotamento sanitário}

Neste tema é analisada a porcentagem de domicílios particulares permanentes que apresentam pelo menos um banheiro, conectado via rede geral de esgoto.

\begin{tabular}{|c|ll|}
\hline \multicolumn{4}{|c|}{ PLANILHA DOMICÍLIO.DBF } \\
\hline CÓDIG( ) & \multicolumn{1}{|c|}{ DESCRIÇÃO } \\
\hline V05 & Domicílios particulares permanentes \\
\hline V26 & $\begin{array}{l}\text { Domicílios particulares permanentes com banheiro ou sanitário e } \\
\text { esgotamento sanitário via rede geral de esgoto ou pluvial }\end{array}$ \\
\hline
\end{tabular}

Quadro 4.7 - Variáveis para classificação de "Domicílios com sanitário e esgotamento da rede geral" (IBGE, 2002)

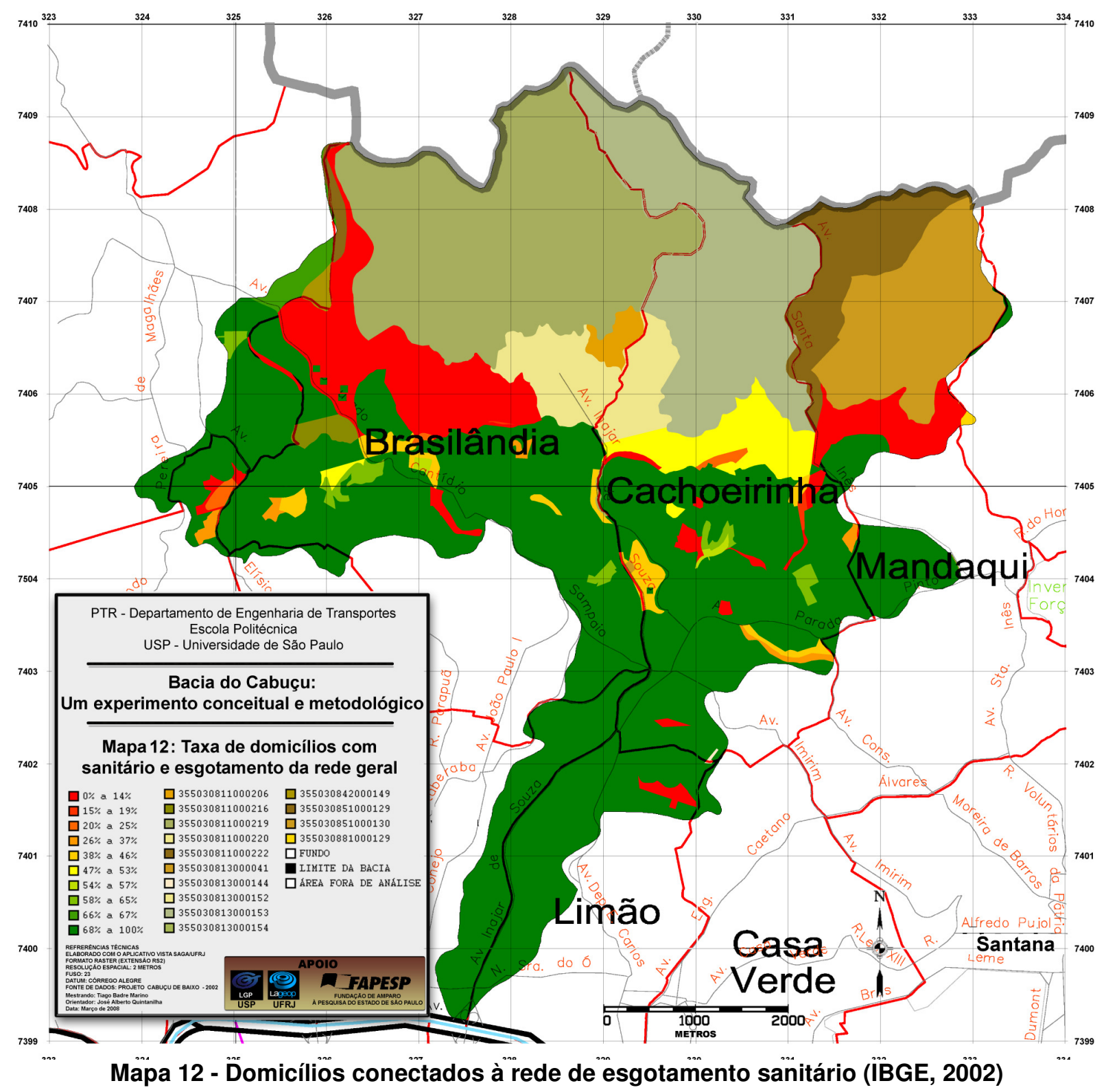




\subsubsection{Condições Demográfico-culturais}

\subsubsection{Densidade média de habitantes por domicílio}

O parâmetro densidade domiciliar foi calculado pelo quociente entre a quantidade total de moradores (V03, da planilha Pessoas.dbf) e o total de domicílios em cada setor censitário (V03, da planilha Domicílios.dbf), seja este permanente ou improvisado. Como resultado obtém-se a média de densidade populacional daquele setor.

\begin{tabular}{|c|c|}
\hline \multicolumn{2}{|c|}{ PLANILHA DOMICÍLIOS.DBF E PESSOAS.DBF } \\
\hline CÓDIG ) & \multicolumn{1}{|c|}{ DESCRIÇÃO } \\
\hline V03 & Domicílios (DOMICÍLIOS.DBF) \\
\hline V03 & Pessoas residentes (PESSOAS.DBF) \\
\hline
\end{tabular}

Quadro 4.8 - Variáveis para classificação de "Densidade média de habitantes por domicílio" (IBGE, 2002)

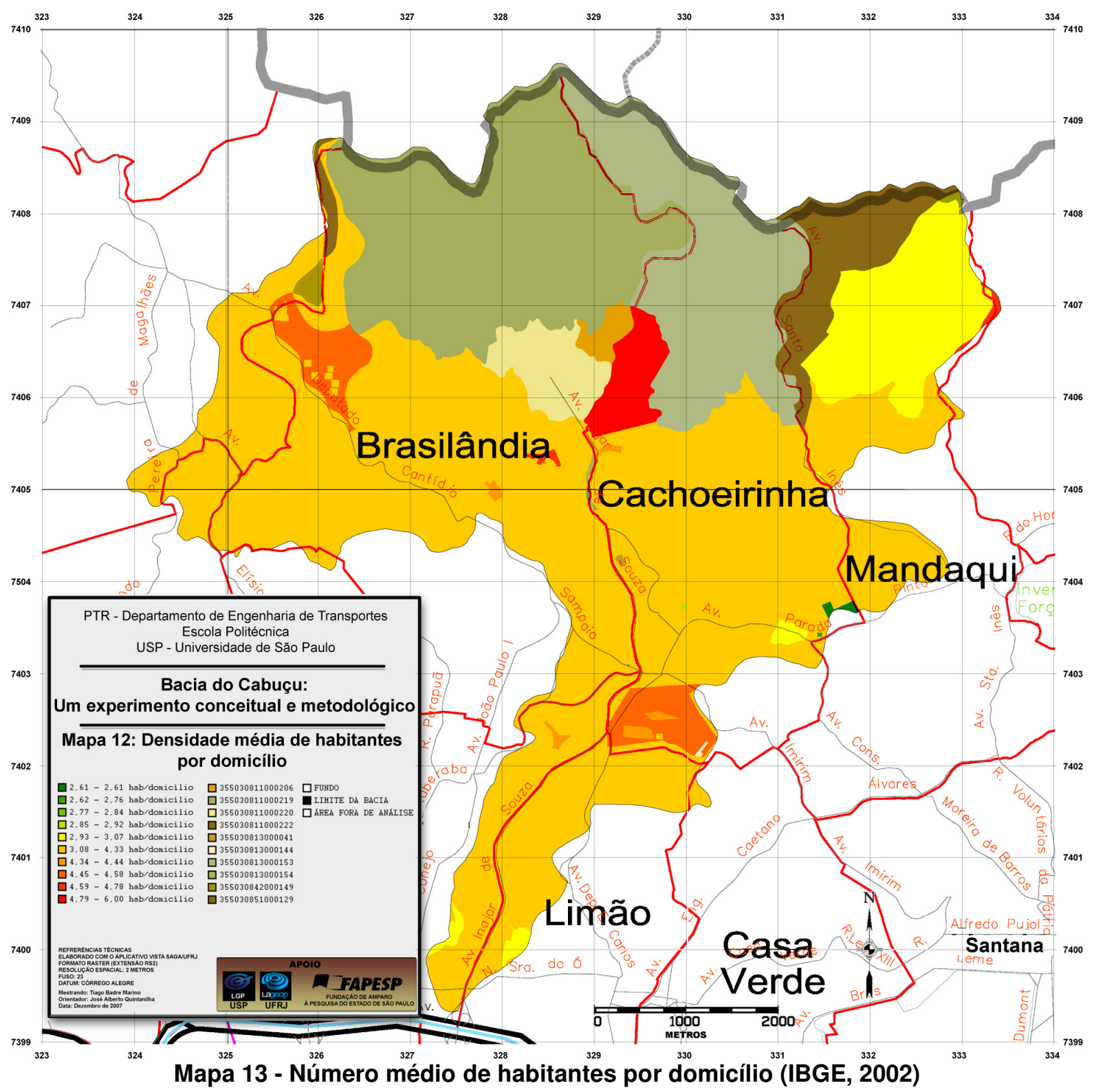




\subsubsection{Nível médio de escolaridade}

O nível de escolaridade foi medido por meio da divisão do número total de anos de estudos dos responsáveis por domicílios permanentes (V129) pela quantidade de pessoas responsáveis por domicílios em cada setor (V03). Como resultado obtém-se a média de anos de estudo de cada setor analisado.

\begin{tabular}{|c|c|}
\hline \multicolumn{2}{|r|}{ PLANILHA RESPONSÁVEL.DBF } \\
\hline CÓDIG। ) & DESCRIÇÃO \\
\hline V03 & Pessoas responsáveis por domicílios particulares permanentes \\
\hline V129 & $\begin{array}{l}\text { Total de anos de estudo das pessoas responsáveis por domicílios } \\
\text { particulares permanentes }\end{array}$ \\
\hline
\end{tabular}

Quadro 4.9 - Variáveis para classificação de "Nível médio de escolaridade" (IBGE,2002)

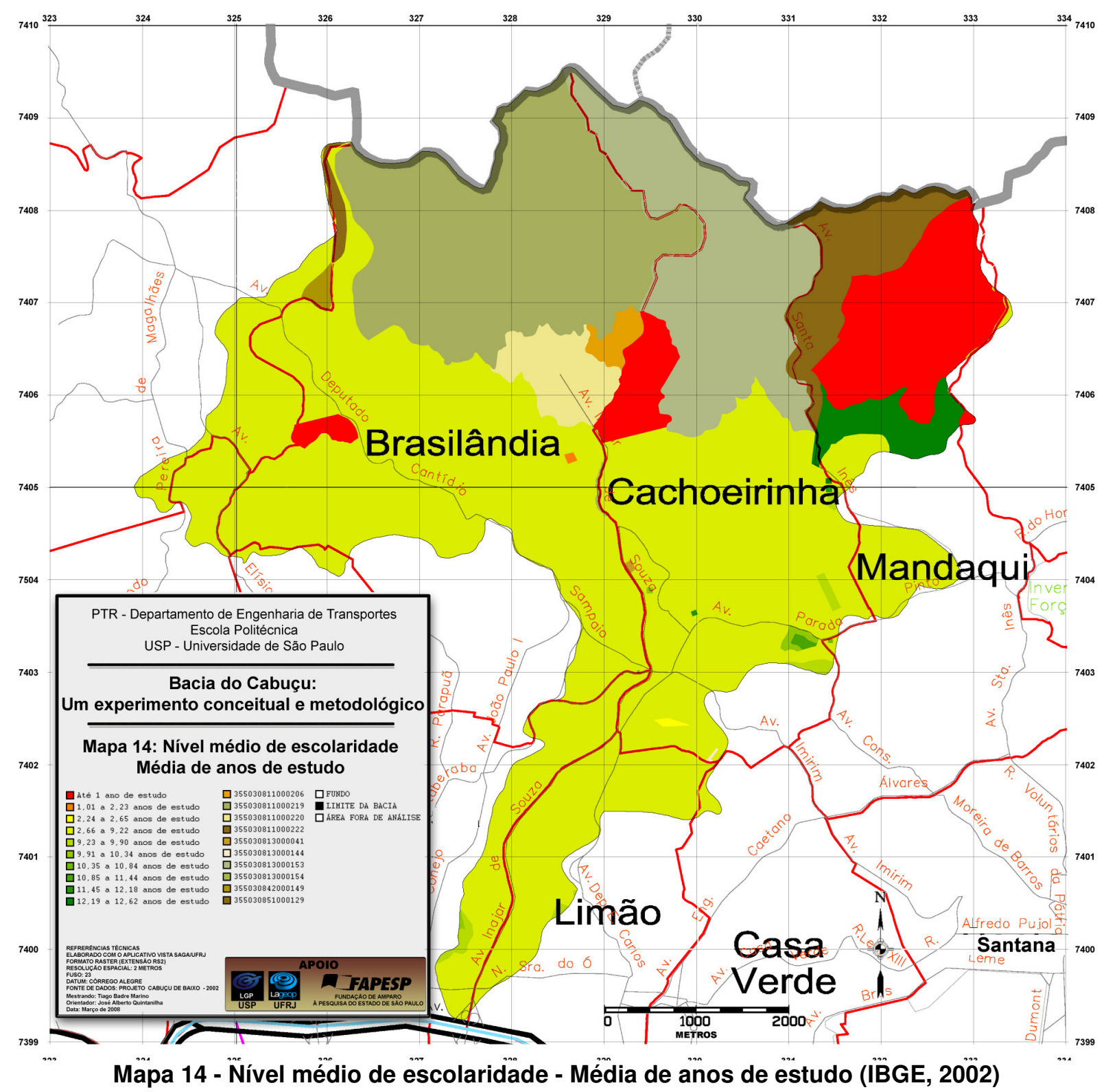




\subsubsection{Nível de analfabetismo}

Considerou-se como alfabetizada a pessoa capaz de ler e escrever um bilhete simples no idioma que conhecia. Aquela que aprendeu a ler e escrever, mas esqueceu e a que apenas assinava o próprio nome foi considerada analfabeta. $\mathrm{O}$ resultado é a faixa percentual de analfabetismo por setor censitário.

\begin{tabular}{|c|c|}
\hline \multicolumn{2}{|c|}{ PLANILHA RESPONSÁVEL.DBF } \\
\hline CÓDIG! ) & DESCRIÇÃO \\
\hline V03 & Pessoas responsáveis pelos domicílios particulares permanentes \\
\hline V25 & Responsáveis por domicílios particulares permanentes não-alfabetizados \\
\hline
\end{tabular}
Quadro 4.10 - Variáveis para classificação de "Nível de analfabetismo" (IBGE, 2002)

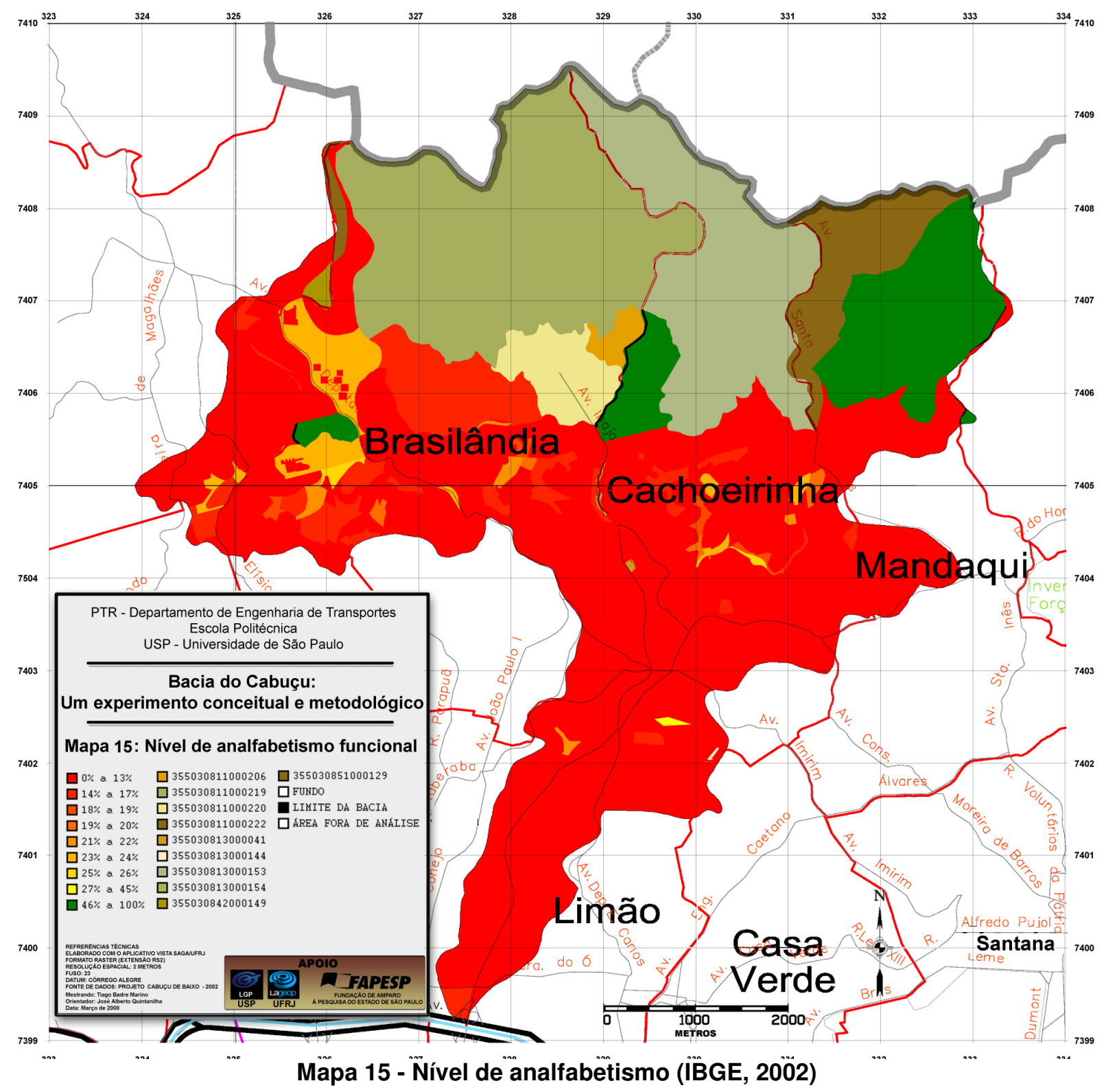




\subsubsection{Condições de Renda}

Determinou-se a dimensão Condições de Renda por meio das variáveis "Renda média dos responsáveis por domicílios" e "Responsáveis com renda inferior a 1 salário mínimo", referentes aos 442 setores censitários da bacia do Cabuçu. Justifica-se esta escolha por ser o parâmetro "renda" um dos principais indicadores de qualidade de vida de um lugar. Para se definir como ocorre a distribuição territorial dos níveis de qualidade de vida, um dos principais objetivos deste trabalho, o mapeamento e a quantificação das condições extremas de renda constituem um dos argumentos determinantes na seleção e classificação de áreas que apresentem níveis de bem-estar correspondentes.

Passa-se agora à consideração das análises e avaliações referentes à situação econômica da população residente na área em estudo.

\subsubsection{Renda média mensal da população}

Considera-se nesta variável a renda média mensal da população da região da bacia do Cabuçu, em Reais (R\$), conforme informação coletada pelo Censo 2000, identificados segundo o setor censitário em que residem.

A renda média mensal por setor foi obtida pela divisão da total de rendimentos mensal dos responsáveis por domicílios (V168) pela quantidade de pessoas responsáveis por domicílios, com rendimento nominal mensal maior que zero (V167).

Foram os seguintes os dados obtidos na classificação segundo o método de classificação Quebras Naturais, expressos no Quadro 4.11:

\begin{tabular}{|c|l|}
\hline \multicolumn{2}{|c|}{ PLANILHA RESPONSÁVEL.DBF } \\
\hline CÓDIG( ) & \multicolumn{1}{|c|}{ DESCRIÇÃO } \\
\hline V167 & $\begin{array}{l}\text { Responsáveis por domicílios particulares permanentes com rendimento } \\
\text { positivo }\end{array}$ \\
\hline V168 & $\begin{array}{l}\text { Total do rendimento nominal mensal das pessoas responsáveis por } \\
\text { domicílios particulares permanentes }\end{array}$ \\
\hline
\end{tabular}

Quadro 4.11 - Variáveis para classificação de “Renda média mensal da população” (IBGE, 2002) 


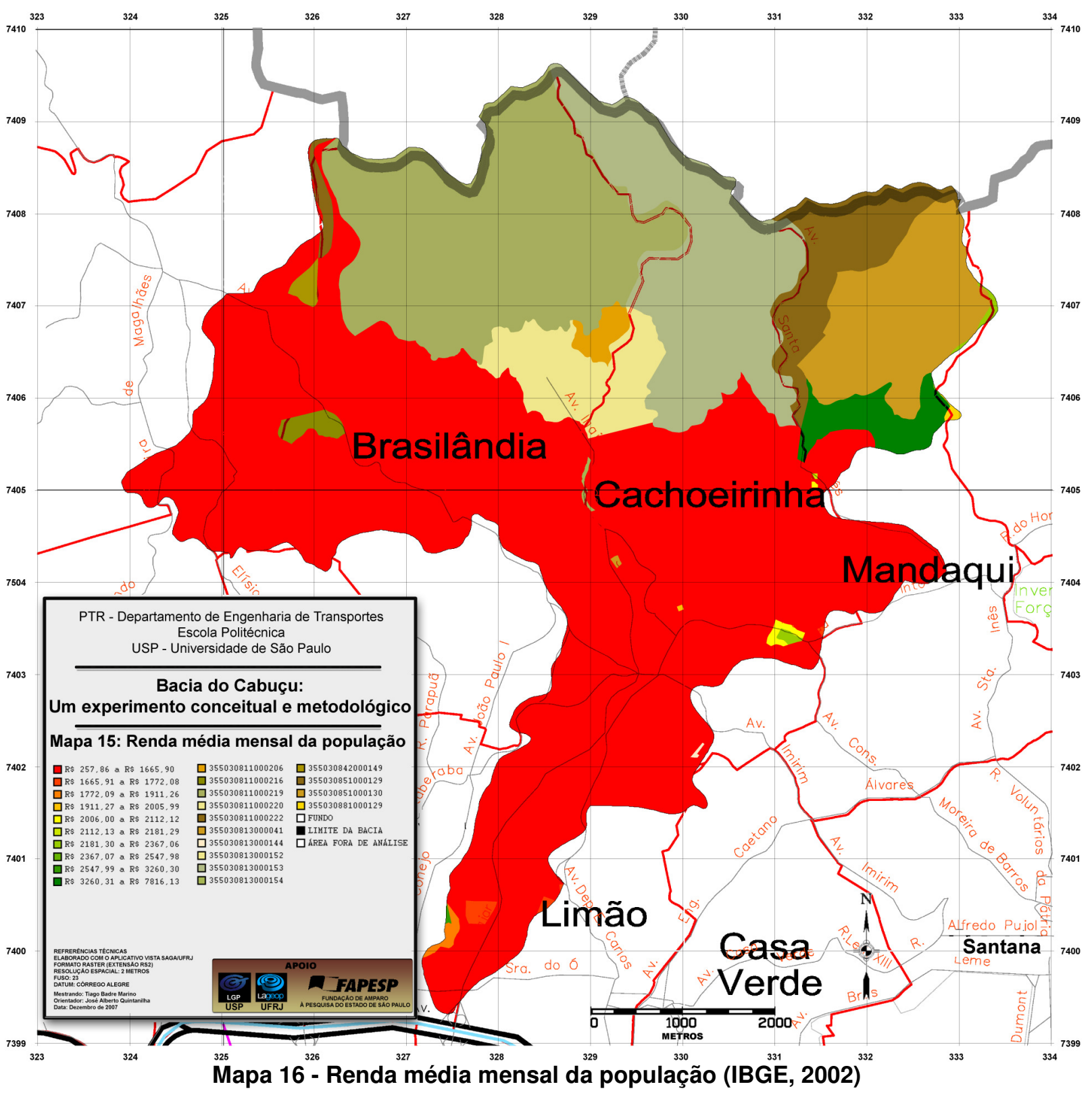

\subsubsection{Responsáveis com renda mensal de até 1 salário mínimo}

Consideram-se nesta variável os responsáveis por domicílios com renda média mensal igual ou inferior a 1 (um) salário mínimo, identificados segundo o setor censitário em que residem.

Para as tabulações do Censo 2000 não há nenhuma variável que expresse este resultado. O que ocorre são variáveis quantificando responsáveis por domicílios com rendimento nominal mensal até 1/2 salário mínimo (V36) e outro campo quantificando o rendimento entre $1 / 2$ e 1 salário mínimo (V37). A estratégia adotada foi então somar estes dois campos numa terceira variável e classificá-la então segundo o método de otimização Quebras Naturais, normalizando pela 
quantidade de responsáveis por domicílios particulares permanentes com rendimento positivo, ou seja, maior que zero (V167).

O resultado será a distribuição percentual de responsáveis por domicílios particulares permanentes com rendimento mensal de até 1 salário mínimo:

\begin{tabular}{|c|l|}
\hline \multicolumn{2}{|c|}{ PLANILHA RESPONSÁVEL.DBF } \\
\hline CÓDIG I ) & \multicolumn{1}{|c|}{ DESCRIÇÃO } \\
\hline V167 & $\begin{array}{l}\text { Responsáveis por domicílios particulares permanentes com rendimento } \\
\text { positivo }\end{array}$ \\
\hline V36 & $\begin{array}{l}\text { Responsáveis por domicílios particulares permanentes com rendimento } \\
\text { nominal mensal de até } 1 / 2 \text { salário mínimo }\end{array}$ \\
\hline V37 & $\begin{array}{l}\text { Responsáveis por domicílios particulares permanentes com rendimento } \\
\text { nominal mensal de mais de 1/2 a 1 salário mínimo }\end{array}$ \\
\hline $\begin{array}{c}\text { V36 } \\
+\end{array}$ & $\begin{array}{l}\text { Responsáveis por domicílios particulares permanentes com rendimento } \\
\text { nominal mensal de até 1 salário mínimo }\end{array}$ \\
\hline
\end{tabular}

Quadro 4.12 - Variáveis para classificação de "Responsáveis com renda mensal de até 1 salário mínimo" (IBGE, 2002) 


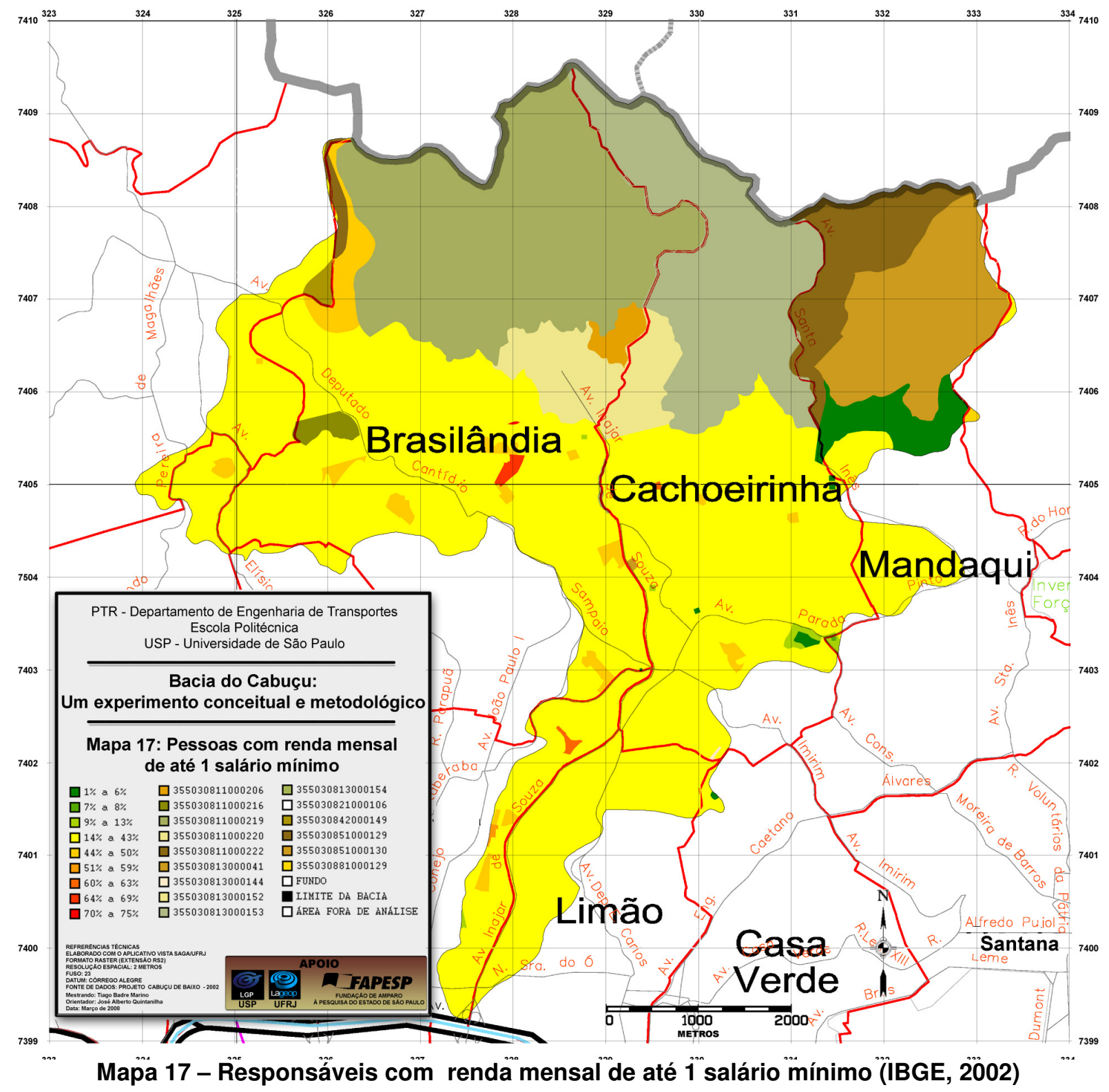




\section{PROCESSAMENTOS E RESULTADOS DAS AVALIAÇÕES AMBIENTAIS}

A seguir serão apresentados os parâmetros utilizados nos cálculos das avaliações e os resultados do processamento das mesmas.

Como se pode verificar na formulação da análise ambiental (item 3.2.3), baseada no Teorema de Bayes, as notas atribuídas a cada classe, são proporcionais à probabilidade de ocorrência do risco analisado, numa escala ordinal de 0 a 10, na visão do grupo de analistas, condicionada à presença desta classe (XAVIER DA SILVA, 2001). Esta escala, com 11 faixas, é mais que suficiente para mensurar o grau de risco do evento analisado. A maioria dos estudos sobre análises de riscos, como CARVALHO, MACEDO e OGURA (2007), utilizam apenas cinco classes (baixíssimo, baixo, médio, alto e altíssimo) para representar o nível de risco.

As classes "BLOQUEADAS" são aquelas que não serão processadas pelo algoritmo, uma vez que não há necessidade de analisar a ocorrência de riscos condicionados às mesmas por não serem antropizadas (ex.: oceano atlântico, rios) ou não estarem dentro do escopo do projeto (ex.: área fora de análise, limite da bacia).

A distribuição de pesos para cada parâmetro possibilita a hierarquização, segundo o ponto de vista dos analistas envolvidos, em função do grau de influência daquele parâmetro na probabilidade da ocorrência do evento analisado, em relação aos demais envolvidos na avaliação. Para fins de normalização, a soma da distribuição dos pesos deve ser igual a 100. 


\subsection{Carta de Riscos de Enchentes - RE}

Em relação aos riscos de enchentes, foram atribuídos os seguintes pesos e notas:

\begin{tabular}{|c|c|}
\hline \multicolumn{2}{|c|}{ Uso do Solo e Cobertura Vegetal - Peso 13\% } \\
\hline CLASSE & NOTA \\
\hline Arruamento & 9 \\
\hline Arruamento sem asfalto & 10 \\
\hline Cemitério & 8 \\
\hline Clubes de campo & 7 \\
\hline Comércio e serviços & 7 \\
\hline Conjuntos residenciais & 7 \\
\hline Edificações & 7 \\
\hline Equipamentos públicos & 7 \\
\hline Indústrias e depósitos & 7 \\
\hline Lagoas de detenção temporária & 10 \\
\hline Limite da bacia & BLOQUEADA \\
\hline Loteamentos desocupados com vegetação & 8 \\
\hline Loteamentos desocupados sem vegetação & 9 \\
\hline Ocupação densa irregular & 10 \\
\hline Ocupação densa regularizada & 9 \\
\hline Área de proteção legal & 5 \\
\hline Área florestal & 4 \\
\hline Área fora de análise & BLOQUEADA \\
\hline Áreas com vegetação & 7 \\
\hline Áreas sem vegetação & 7 \\
\hline Áreas vagas com vegetação & 7 \\
\hline Áreas vagas sem vegetação & 8 \\
\hline Áreas vagas sem vegetação & 8 \\
\hline Áreas verdes urbanas & 9 \\
\hline \multicolumn{2}{|c|}{ Declividades - Peso 22\% } \\
\hline CLASSE & NOTA \\
\hline $0-0.58$ & 10 \\
\hline $0.58-1.15$ & 10 \\
\hline $1.15-2.3$ & 9 \\
\hline $2.3-2.86$ & 8 \\
\hline $2.86-4.57$ & 8 \\
\hline $4.57-5.14$ & 7 \\
\hline $5.71-8.5$ & 6 \\
\hline $5.14-5.71$ & 5 \\
\hline $8.5-11.3$ & 4 \\
\hline $11.3-14.03$ & 2 \\
\hline $14.03-26.56$ & 1 \\
\hline $26.56-45$ & 0 \\
\hline $45-63.43$ & 0 \\
\hline $63.43-90$ & 0 \\
\hline Limite da bacia & BLOQUEADA \\
\hline Área fora de análise & BLOQUEADA \\
\hline Área expandida & BLOQUEADA \\
\hline \multicolumn{2}{|c|}{ Hipsometria - Peso 5\% } \\
\hline CLASSE & NOTA \\
\hline $715-765 \mathrm{M}$ & 10 \\
\hline $765-775 \mathrm{M}$ & 9 \\
\hline $775-785 M$ & 9 \\
\hline $785-795 M$ & 9 \\
\hline $795-805 \mathrm{M}$ & 8 \\
\hline
\end{tabular}




\begin{tabular}{|c|c|}
\hline $805-815 \mathrm{M}$ & 7 \\
\hline $815-825 M$ & 6 \\
\hline $825-905 M$ & 5 \\
\hline $905-965 \mathrm{M}$ & 4 \\
\hline $965-1025 \mathrm{M}$ & 3 \\
\hline $1025-1035 \mathrm{M}$ & 1 \\
\hline $1035-1045 \mathrm{M}$ & 1 \\
\hline $1045-1055 M$ & 1 \\
\hline 1055- $1065 \mathrm{M}$ & 0 \\
\hline $1065-1075 \mathrm{M}$ & $\mathbf{0}$ \\
\hline $1075-1215 \mathrm{M}$ & 5 \\
\hline Fundo & BLOQUEADA \\
\hline Limite da bacia & BLOQUEADA \\
\hline Área fora de análise & BLOQUEADA \\
\hline \multicolumn{2}{|c|}{ Geologia - Peso 10\% } \\
\hline CLASSE & NOTA \\
\hline Área fora de análise & BLOQUEADA \\
\hline Limite da bacia & BLOQUEADA \\
\hline Dep.leques aluviais & 10 \\
\hline Dep.sedimentos.aluvionares & 10 \\
\hline Micaxistos e quartzitos & 7 \\
\hline Rochas graníticas & 7 \\
\hline Rochas metacarbonáticas & 7 \\
\hline \multicolumn{2}{|c|}{ Geomorfologia - Peso 17\% } \\
\hline CLASSE & NOTA \\
\hline Área fora de análise & BLOQUEADA \\
\hline Limite da bacia & BLOQUEADA \\
\hline Colinas pequenas & 1 \\
\hline Morros & 1 \\
\hline Morros e montanhas & 1 \\
\hline Planícies fluviais & 10 \\
\hline Setores de encostas íngremes & 0 \\
\hline \multicolumn{2}{|c|}{$\begin{array}{ll}\text { Proximidade de Rede Viária - Peso } 13 \% \\
\end{array}$} \\
\hline CLASSE & NOTA \\
\hline Arruamento & 9 \\
\hline Arruamento sem asfalto & 10 \\
\hline$<10 \mathrm{~m}$ ruas $\mid 11 \mathrm{~m}$ a $20 \mathrm{~m}$ ruas $\mathrm{s} /$ asfalto & 8 \\
\hline$<10 \mathrm{~m}$ ruas $\mid>20 \mathrm{~m}$ ruas $\mathrm{s} /$ asfalto & 7 \\
\hline $11 \mathrm{~m}$ a $20 \mathrm{~m}$ ruas $\mid<10 \mathrm{~m}$ ruas $\mathrm{s} /$ asfalto & 9 \\
\hline $11 \mathrm{~m}$ a $20 \mathrm{~m}$ ruas $\mid 11 \mathrm{~m}$ a $20 \mathrm{~m}$ ruas $\mathrm{s} /$ asfalto & 7 \\
\hline $11 \mathrm{~m}$ a $20 \mathrm{~m}$ ruas $\mid>20 \mathrm{~m}$ ruas $\mathrm{s} /$ asfalto & 6 \\
\hline$>20 \mathrm{~m}$ ruas $\mid<10 \mathrm{~m}$ ruas $\mathrm{s} /$ asfalto & 8 \\
\hline$>20 \mathrm{~m}$ ruas $\mathrm{s} /$ asfalto $\mid 11 \mathrm{~m}$ a $20 \mathrm{~m}$ ruas $\mathrm{s} / \mathrm{a}$ & 5 \\
\hline$>20 \mathrm{~m}$ ruas $\mid>20 \mathrm{~m}$ ruas $\mathrm{s} /$ asfalto & 2 \\
\hline Limite da bacia & BLOQUEADA \\
\hline Área fora de análise & BLOQUEADA \\
\hline \multicolumn{2}{|c|}{ Proximidade de Superfícies Líquidas - Peso $20 \%$} \\
\hline CLASSE & NOTA \\
\hline Piscinões & 10 \\
\hline Até $20 \mathrm{~m}$ piscinões & 9 \\
\hline Até $50 \mathrm{~m}$ piscinões & 8 \\
\hline Drenagem & 10 \\
\hline Até $20 \mathrm{~m}$ drenagem & 9 \\
\hline De $20 \mathrm{~m}$ a $50 \mathrm{~m}$ drenagem & 8 \\
\hline De $50 \mathrm{~m}$ a $100 \mathrm{~m}$ drenagem & 5 \\
\hline$>50 \mathrm{~m}$ piscinões e $>100 \mathrm{~m}$ drenagem & 2 \\
\hline
\end{tabular}




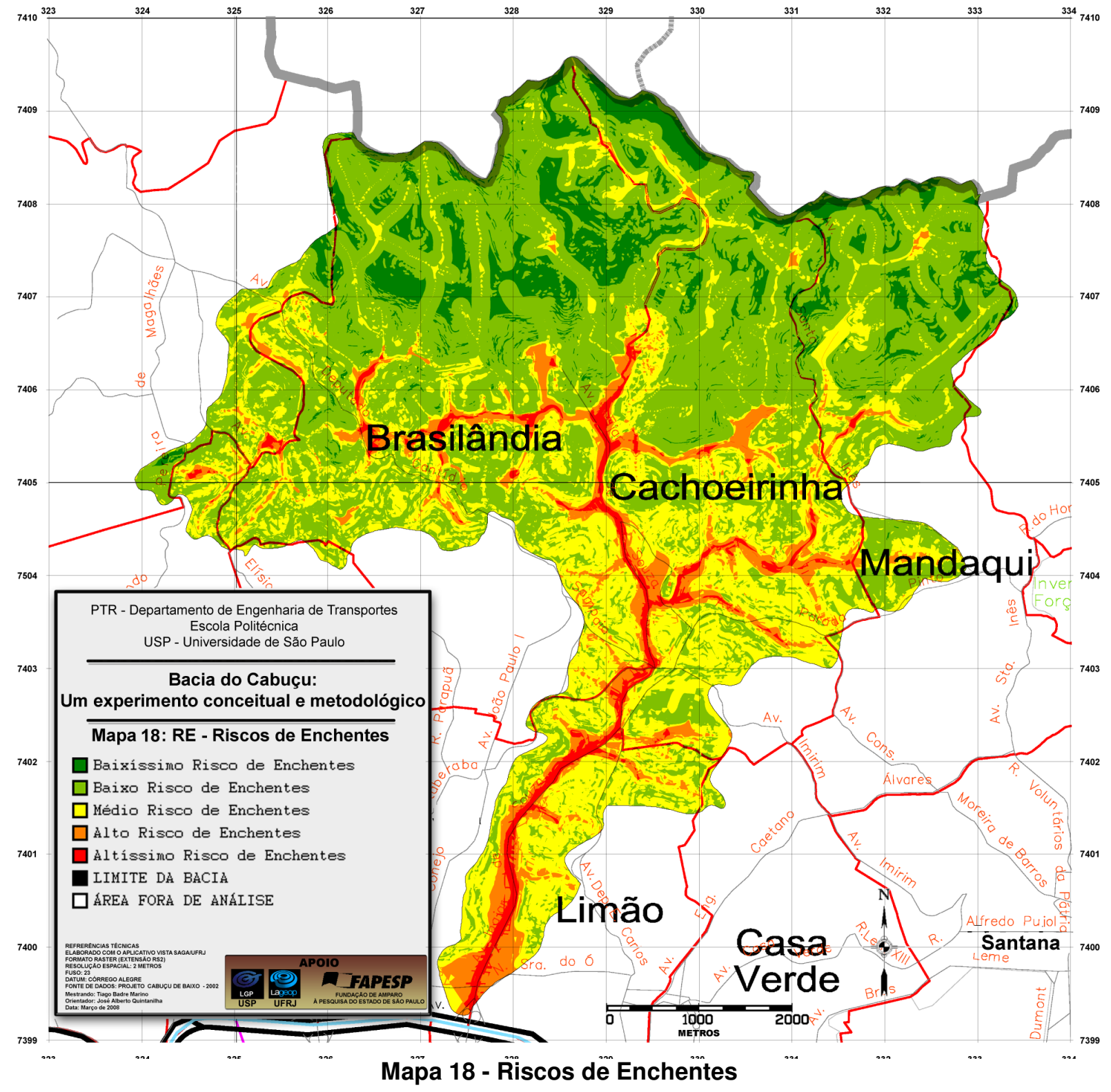




\subsection{Carta de Riscos de Deslizamentos/Desmoronamentos - RDD}

Para o mapeamento dos riscos de deslizamentos, as classes de cada mapa receberam notas, num intervalo de 0 a 10, representando a probabilidade, segundo o avaliador, da ocorrência de deslizamentos e desmoronamentos, diante da presença da classe analisada. Os parâmetros (mapas) físicos envolvidos na análise também receberam pesos, de forma a hierarquizá-los, de acordo com o grau de importância de cada um desses parâmetros para a ocorrência de deslizamentos e desmoronamentos. Os pesos e notas foram então distribuídos da seguinte forma:

\begin{tabular}{|c|c|}
\hline \multicolumn{2}{|c|}{ Uso do Solo e Cobertura Vegetal - Peso $15 \%$} \\
\hline CLASSE & NOTA \\
\hline Arruamento & 8 \\
\hline Arruamento sem asfalto & 10 \\
\hline Cemitério & 2 \\
\hline Clubes de campo & 7 \\
\hline Comércio e serviços & 7 \\
\hline Conjuntos residenciais & 7 \\
\hline Edificações & 7 \\
\hline Equipamentos públicos & 7 \\
\hline Indústrias e depósitos & 7 \\
\hline Lagoas de detenção temporária & 0 \\
\hline Limite da bacia & BLOQUEADA \\
\hline Loteamentos desocupados com vegetação & 8 \\
\hline Loteamentos desocupados sem vegetação & 9 \\
\hline Ocupação densa irregular & 10 \\
\hline Ocupação densa regularizada & 9 \\
\hline Área de proteção legal & 5 \\
\hline Área florestal & 2 \\
\hline Área fora de análise & BLOQUEEADA \\
\hline Áreas com vegetação & 4 \\
\hline Áreas sem vegetação & 5 \\
\hline Áreas vagas com vegetação & 4 \\
\hline Äreas vagas sem vegetação & 6 \\
\hline Áreas vagas sem vegetação & 6 \\
\hline Áreas verdes urbanas & 3 \\
\hline \multicolumn{2}{|c|}{ Declividades - Peso 25\% } \\
\hline CLASSE & NOTA \\
\hline $0-0.58$ & 0 \\
\hline $0.58-1.15$ & 0 \\
\hline $1.15-2.3$ & 1 \\
\hline $2.3-2.86$ & 3 \\
\hline $2.86-4.57$ & 4 \\
\hline $4.57-5.14$ & 5 \\
\hline $5.71-8.5$ & 6 \\
\hline $5.14-5.71$ & 7 \\
\hline $8.5-11.3$ & 8 \\
\hline $11.3-14.03$ & 8 \\
\hline $14.03-26.56$ & 9 \\
\hline $26.56-45$ & 9 \\
\hline $45-63.43$ & 9 \\
\hline $63.43-90$ & 10 \\
\hline
\end{tabular}




\begin{tabular}{|c|c|}
\hline Limite da bacia & BLOQUEADA \\
\hline Área fora de análise & BLOQUEADA \\
\hline Área expandida & BLOQUEADA \\
\hline \multicolumn{2}{|c|}{ Hipsometria - Peso $5 \%$} \\
\hline CLASSE & NOTA \\
\hline $715-765 \mathrm{M}$ & 0 \\
\hline $765-775 \mathrm{M}$ & 1 \\
\hline $775-785 M$ & 1 \\
\hline $785-795 M$ & 1 \\
\hline $795-805 \mathrm{M}$ & 2 \\
\hline $805-815 \mathrm{M}$ & 3 \\
\hline $815-825 \mathrm{M}$ & 4 \\
\hline $825-905 \mathrm{M}$ & 5 \\
\hline $905-965 \mathrm{M}$ & 6 \\
\hline $965-1025 \mathrm{M}$ & 7 \\
\hline $1025-1035 \mathrm{M}$ & 6 \\
\hline $1035-1045 \mathrm{M}$ & 5 \\
\hline $1045-1055 M$ & 9 \\
\hline 1055- $1065 \mathrm{M}$ & 10 \\
\hline $1065-1075 \mathrm{M}$ & 10 \\
\hline $1075-1215 \mathrm{M}$ & 5 \\
\hline Fundo & BLOQUEADA \\
\hline Limite da bacia & BLOQUEADA \\
\hline Área fora de análise & BLOQUEADA \\
\hline \multicolumn{2}{|c|}{ Geologia - Peso $20 \%$} \\
\hline CLASSE & NOTA \\
\hline Área fora de análise & BLOQUEADA \\
\hline Limite da bacia & BLOQUEADA \\
\hline Dep.leques aluviais & 0 \\
\hline Dep.sed.aluvionares & 0 \\
\hline Micaxistos e quartzitos & 10 \\
\hline Rochas graníticas & 10 \\
\hline Rochas metacarbonáticas & 10 \\
\hline \multicolumn{2}{|c|}{ Geomorfologia - Peso $20 \%$} \\
\hline CLASSE & NOTA \\
\hline Área fora de análise & BLOQUEADA \\
\hline Limite da bacia & BLOQUEADA \\
\hline Colinas pequenas & 8 \\
\hline Morros & 8 \\
\hline Morros e montanhas & 9 \\
\hline Planícies fluviais & 0 \\
\hline Setores de encostas íngremes & 10 \\
\hline \multicolumn{2}{|c|}{ Proximidade de Rede Viária - Peso $8 \%$} \\
\hline CLASSE & NOTA \\
\hline Arruamento & 8 \\
\hline Arruamento sem asfalto & 10 \\
\hline$<10 \mathrm{~m}$ ruas $\mid 11 \mathrm{~m}$ a $20 \mathrm{~m}$ ruas $\mathrm{s} /$ asfalto & 8 \\
\hline$<10 \mathrm{~m}$ ruas $\mid>20 \mathrm{~m}$ ruas $\mathrm{s} /$ asfalto & 6 \\
\hline $11 \mathrm{~m}$ a $20 \mathrm{~m}$ ruas $\mid<10 \mathrm{~m}$ ruas $\mathrm{s} /$ asfalto & 8 \\
\hline $11 \mathrm{~m}$ a $20 \mathrm{~m}$ ruas $11 \mathrm{~m}$ a $20 \mathrm{~m}$ ruas $\mathrm{s} /$ asfalto & 7 \\
\hline $11 \mathrm{~m}$ a $20 \mathrm{~m}$ ruas $\mid>20 \mathrm{~m}$ ruas $\mathrm{s} /$ asfalto & 5 \\
\hline$>20 \mathrm{~m}$ ruas $\mid<10 \mathrm{~m}$ ruas $\mathrm{s} /$ asfalto & 7 \\
\hline$>20 \mathrm{~m}$ ruas $\mathrm{s} /$ asfalto $\mid 11 \mathrm{~m}$ a $20 \mathrm{~m}$ ruas $\mathrm{s} / \mathrm{a}$ & 6 \\
\hline$>20 \mathrm{~m}$ ruas $\mid>20 \mathrm{~m}$ ruas $\mathrm{s} /$ asfalto & $\mathbf{0}$ \\
\hline Limite da bacia & BLOQUEADA \\
\hline Área fora de análise & BLOQUEADA \\
\hline \multicolumn{2}{|c|}{ Proximidade de Superfícies Líquidas - Peso 7\% } \\
\hline CLASSE & NOTA \\
\hline
\end{tabular}




\begin{tabular}{|l|c|}
\hline Piscinões & 0 \\
\hline Até 20m piscinões & 8 \\
\hline Até 50m piscinões & 5 \\
\hline Drenagem & 0 \\
\hline Até 20m drenagem & 8 \\
\hline De 20m a 50m drenagem & 6 \\
\hline De 50m a 100m drenagem & 3 \\
\hline$>50 \mathrm{~m}$ piscinões e >100m drenagem & 0 \\
\hline Limite da bacia & BLOQUEADA \\
\hline Área fora de análise & BLOQUEADA \\
\hline
\end{tabular}

Quadro 5.2 - Pesos e notas atribuídos aos parâmetros para Riscos de Deslizamentos/Desmoronamentos

Concluídas as avaliações, as classes de riscos foram agrupadas em cinco níveis: baixíssimo, baixo, médio, alto e altíssimo risco. As áreas de risco elevado foram localizadas, em sua maioria, nas médias altitudes e áreas de declividades acentuadas (peso de $25 \%$ para este fator físico).

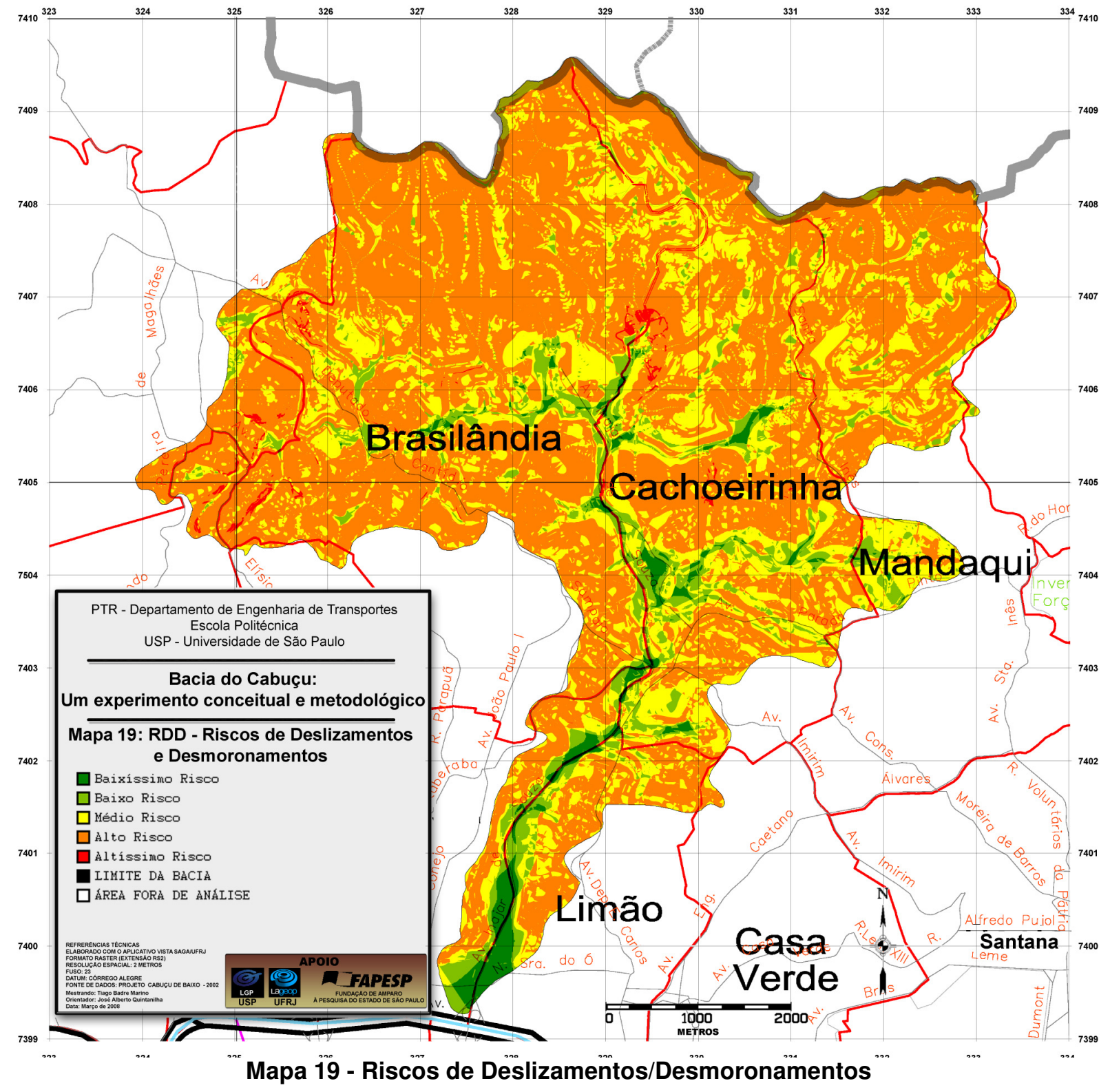




\subsection{Carta de Infra-Estrutura Básica}

Para a análise de infra-estrutura básica provida pelo Estado, notas mais baixas foram atribuídas às classes onde foram mapeados setores com baixa porcentagem de domicílios abastecidos por água canalizada, coleta de lixo e esgotamento sanitário. Analogamente, os setores que apresentam maior valor percentual são os que se apresentam melhores assistidos pelo Estado, quanto à infra-estrutura, recebendo então as maiores notas.

\begin{tabular}{|c|c|c|}
\hline \multicolumn{3}{|c|}{ Domicílios com abastecimento de água canalizada - Peso $40 \%$} \\
\hline & CLASSE & NOTA \\
\hline $01 \%$ A $09 \%$ & & 0 \\
\hline $10 \%$ A $45 \%$ & & 3 \\
\hline $46 \%$ A $87 \%$ & & 6 \\
\hline $88 \%$ A $89 \%$ & & 7 \\
\hline $90 \%$ A $91 \%$ & & 9 \\
\hline $91 \%$ A $93 \%$ & & 9 \\
\hline $94 \%$ A $95 \%$ & & 9 \\
\hline $96 \%$ A $97 \%$ & & 10 \\
\hline $98 \%$ A $100 \%$ & & 10 \\
\hline \multicolumn{3}{|c|}{ Domicílios com coleta de lixo por serviço de limpeza - Peso $30 \%$} \\
\hline & CLASSE & NOTA \\
\hline $0 \%$ A $2 \%$ & & 0 \\
\hline 3\% A 9\% & & 1 \\
\hline $10 \%$ A $24 \%$ & & 2 \\
\hline $25 \%$ A $39 \%$ & & 3 \\
\hline $40 \%$ A $45 \%$ & & 4 \\
\hline $46 \%$ A $55 \%$ & & 5 \\
\hline $56 \%$ A $65 \%$ & & 6 \\
\hline $66 \%$ A $72 \%$ & & 7 \\
\hline 73\% A 76\% & & 7 \\
\hline $77 \%$ A $100 \%$ & & 9 \\
\hline \multicolumn{3}{|c|}{ Domicílios conectados à rede de esgotamento sanitário - Peso $30 \%$} \\
\hline & CLASSE & NOTA \\
\hline $0 \%$ A 14\% & & 0 \\
\hline $15 \%$ A $19 \%$ & & 1 \\
\hline $20 \%$ A $25 \%$ & & 2 \\
\hline $26 \%$ A $37 \%$ & & 3 \\
\hline $38 \%$ A $46 \%$ & & 4 \\
\hline $47 \%$ A $53 \%$ & & 5 \\
\hline $54 \%$ A $57 \%$ & & 5 \\
\hline $58 \%$ A $65 \%$ & & 6 \\
\hline $66 \%$ A 67\% & & 7 \\
\hline $68 \%$ A $100 \%$ & & 9 \\
\hline
\end{tabular}

Quadro 5.3 - Pesos e notas atribuídos aos parâmetros para Infra-estrutura básica 


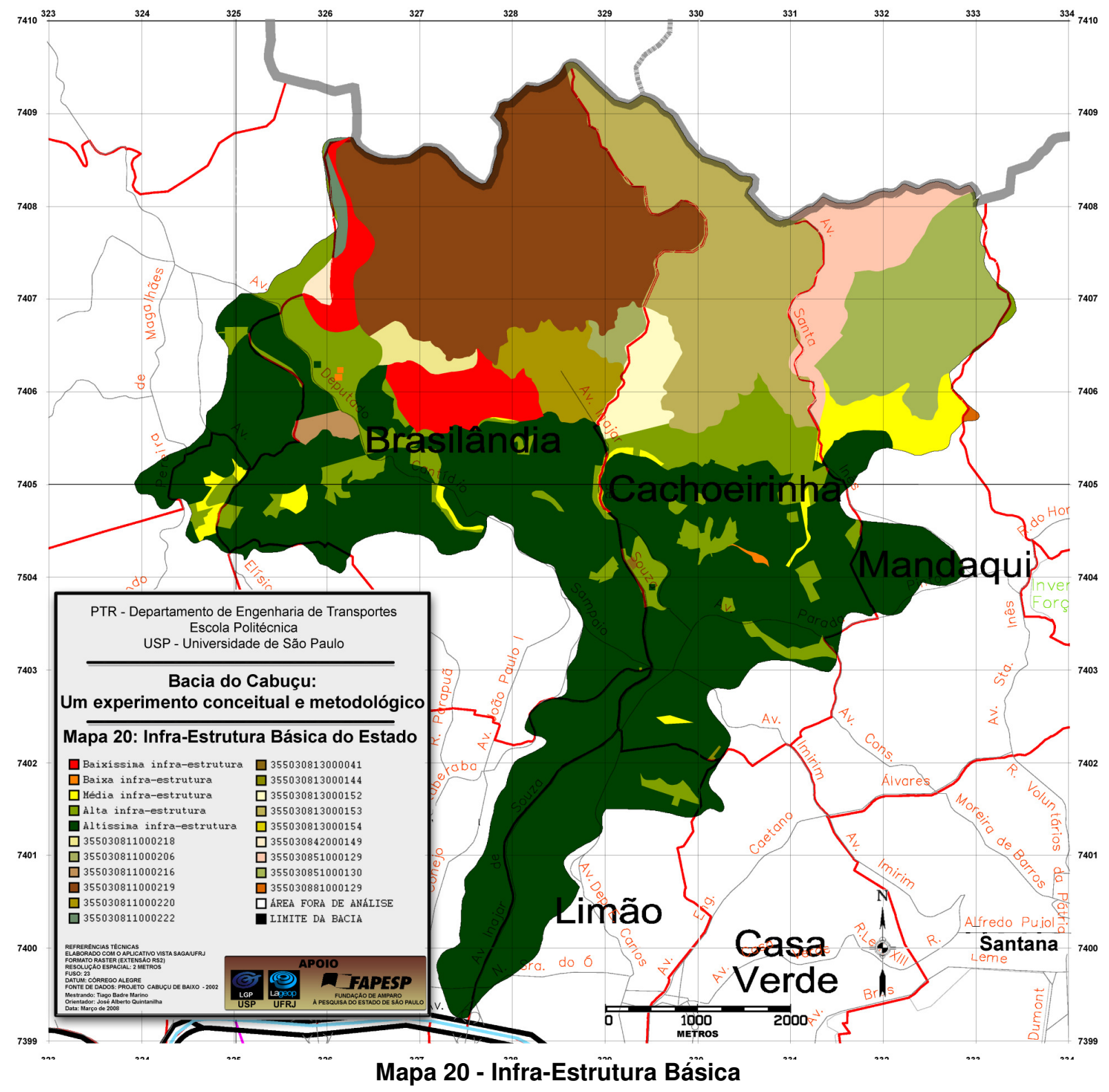




\subsection{Carta de Condições Demográfico-culturais}

Quanto às condições demográfico-culturais, a boa qualidade de vida está relacionada à pequena densidade populacional domiciliar, alta média de anos de estudos, além da baixa taxa de analfabetismo do setor analisado.

Portanto, para o tema "Número médio de habitantes por domicílio", setores que apresentam menor densidade populacional domiciliar recebem maiores notas (melhor qualidade de vida). Quanto aos "Níveis de Escolaridade", a setores que apresentam maiores médias de anos de estudo, são atribuídas maiores notas.

Por fim, quanto ao tema "Taxa de Analfabetismo", as maiores notas são atribuídas a setores que apresentam as mais elevadas taxas de analfabetos. A este último tema foi atribuída maior importância ( $50 \%$ de peso), sendo este o principal parâmetro desta análise.

\begin{tabular}{|c|c|}
\hline \multicolumn{2}{|c|}{ Densidade média de habitantes por domicílio - Peso $20 \%$} \\
\hline CLASSE & NOTA \\
\hline 2,61 - 2,61 hab/domicílio & 10 \\
\hline 2,62 - 2,76 hab/domicílio & 9 \\
\hline 2,77 - 2,84 hab/domicílio & 8 \\
\hline 2,85 - 2,92 hab/domicílio & 7 \\
\hline 2,93 - 3,07 hab/domicílio & 6 \\
\hline 3,08 - 4,33 hab/domicílio & 5 \\
\hline 4,34 - 4,44 hab/domicílio & 4 \\
\hline 4,45 - 4,58 hab/domicílio & 3 \\
\hline 4,59 - 4,78 hab/domicílio & 2 \\
\hline 4,79 - 6,00 hab/domicílio & 1 \\
\hline \multicolumn{2}{|c|}{ Nível de escolaridade - Média Anos de Estudo - Peso $40 \%$} \\
\hline CLASSE & NOTA \\
\hline Até 1 ano de estudo & 0 \\
\hline 1,01 a 2,23 anos de estudo & 1 \\
\hline 2,24 a 2,65 anos de estudo & 2 \\
\hline 2,66 a 9,22 anos de estudo & 3 \\
\hline 9,23 a 9,90 anos de estudo & 6 \\
\hline 9,91 a 10,34 anos de estudo & 6 \\
\hline 10,35 a 10,84 anos de estudo & 7 \\
\hline 10,85 a 11,44 anos de estudo & 8 \\
\hline 11,45 a 12,18 anos de estudo & 9 \\
\hline 12,19 a 12,62 anos de estudo & 10 \\
\hline \multicolumn{2}{|c|}{ Nível de analfabetismo - Peso $40 \%$} \\
\hline CLASSE & NOTA \\
\hline $0 \%$ A 13\% & 10 \\
\hline $14 \%$ A $17 \%$ & 9 \\
\hline $18 \%$ A $19 \%$ & 8 \\
\hline $19 \%$ A $20 \%$ & 7 \\
\hline $21 \%$ A $22 \%$ & 6 \\
\hline $23 \%$ A $24 \%$ & 5 \\
\hline $25 \%$ A $26 \%$ & 4 \\
\hline $27 \%$ A $45 \%$ & 2 \\
\hline $46 \%$ A $100 \%$ & 0 \\
\hline
\end{tabular}

Quadro 5.4 - Pesos e notas atribuídos aos parâmetros para Condições Sociais e Herança Cultural 


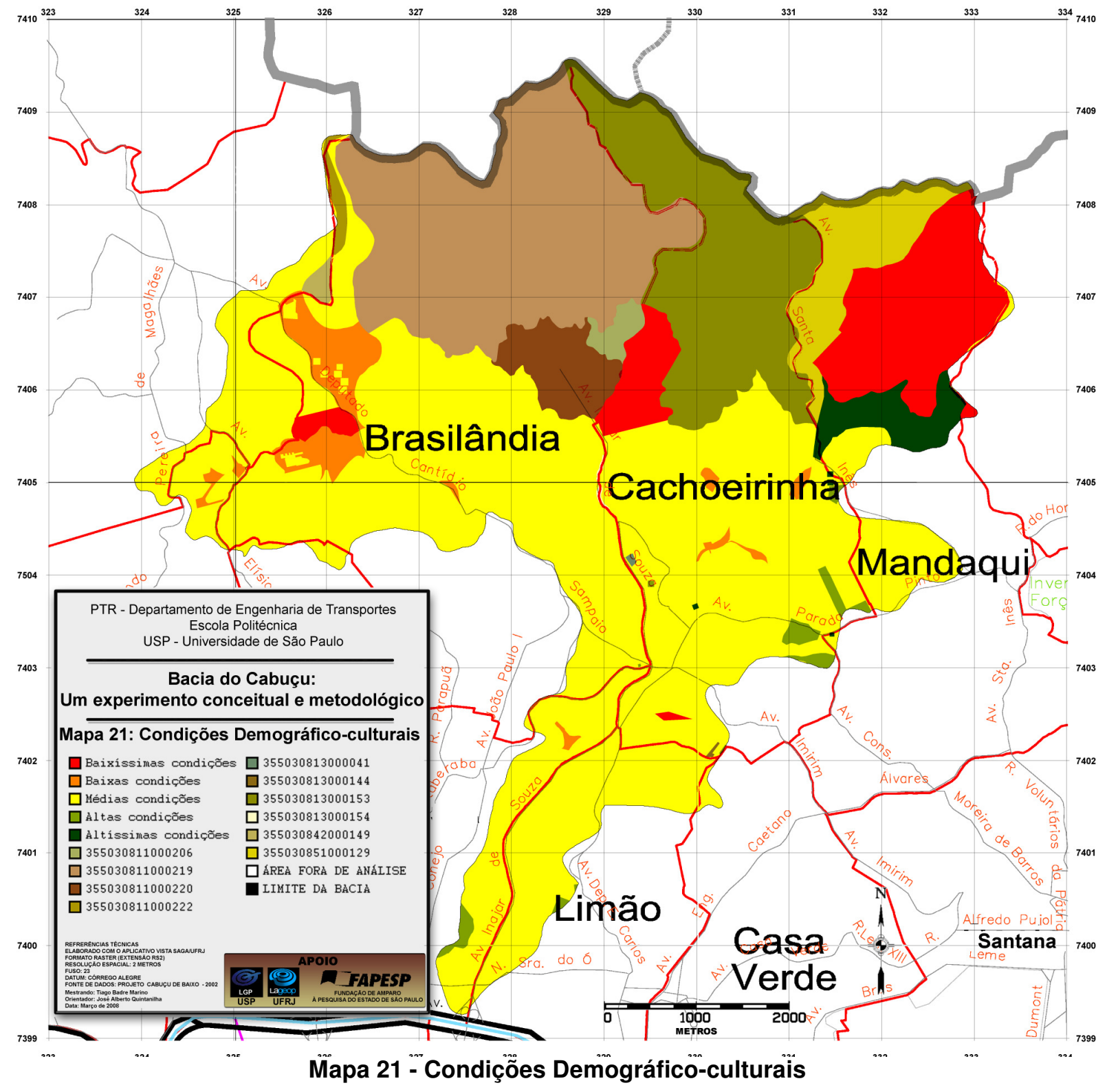




\subsection{Carta de Condições de Renda}

De acordo com a Árvore de Decisão apresentada por XAVIER DA SILVA (2007), no contexto econômico, foram julgados apenas dois parâmetros, inferindo-se que:

- Quanto maior a renda média mensal $\rightarrow$ melhor qualidade de vida $\rightarrow$ melhor nota;

- Setores que apresentam as menores taxas de chefes de domicílios cuja renda mensal é menor que um salário mínimo $\rightarrow$ melhor qualidade de vida $\rightarrow$ melhor nota.

\begin{tabular}{|c|c|}
\hline \multicolumn{2}{|c|}{ Renda média mensal da população em Reais (R\$) - Peso $40 \%$} \\
\hline CLASSE & NOTA \\
\hline$R \$ 257,86$ A R $\$ 1665,90$ & 0 \\
\hline R\$ 1665,91 A R\$ 1772,08 & 5 \\
\hline$R \$ 1772,09$ A R\$ 1911,26 & 6 \\
\hline R\$ 1911,27 A R\$ 2005,99 & 7 \\
\hline$R \$ 2006,00$ A R\$ 2112,12 & 8 \\
\hline$R \$ 2112,13$ A R\$ 2181,29 & 9 \\
\hline $\mathrm{R} \$ 2181,30$ A R\$ 2367,06 & 9 \\
\hline $\mathrm{R} \$ 2367,07$ A R\$ 2547,98 & 9 \\
\hline$R \$ 2547,99$ A R\$ 3260,30 & 10 \\
\hline R\$ 3260,31 A R\$ 7816,13 & 10 \\
\hline \multicolumn{2}{|c|}{ Responsáveis com renda mensal de até 1 salário mínimo - Peso $60 \%$} \\
\hline CLASSE & NOTA \\
\hline $1 \%$ A $6 \%$ & 10 \\
\hline $7 \%$ A $8 \%$ & 9 \\
\hline $9 \%$ A $13 \%$ & 8 \\
\hline $14 \%$ A $43 \%$ & 7 \\
\hline $44 \%$ A $50 \%$ & 5 \\
\hline $51 \%$ A $59 \%$ & 4 \\
\hline $60 \%$ A 63\% & 3 \\
\hline $64 \%$ A $69 \%$ & 2 \\
\hline $70 \%$ A $75 \%$ & 0 \\
\hline
\end{tabular}

Quadro 5.5 - Pesos e notas atribuídos aos parâmetros para Condições de Renda 


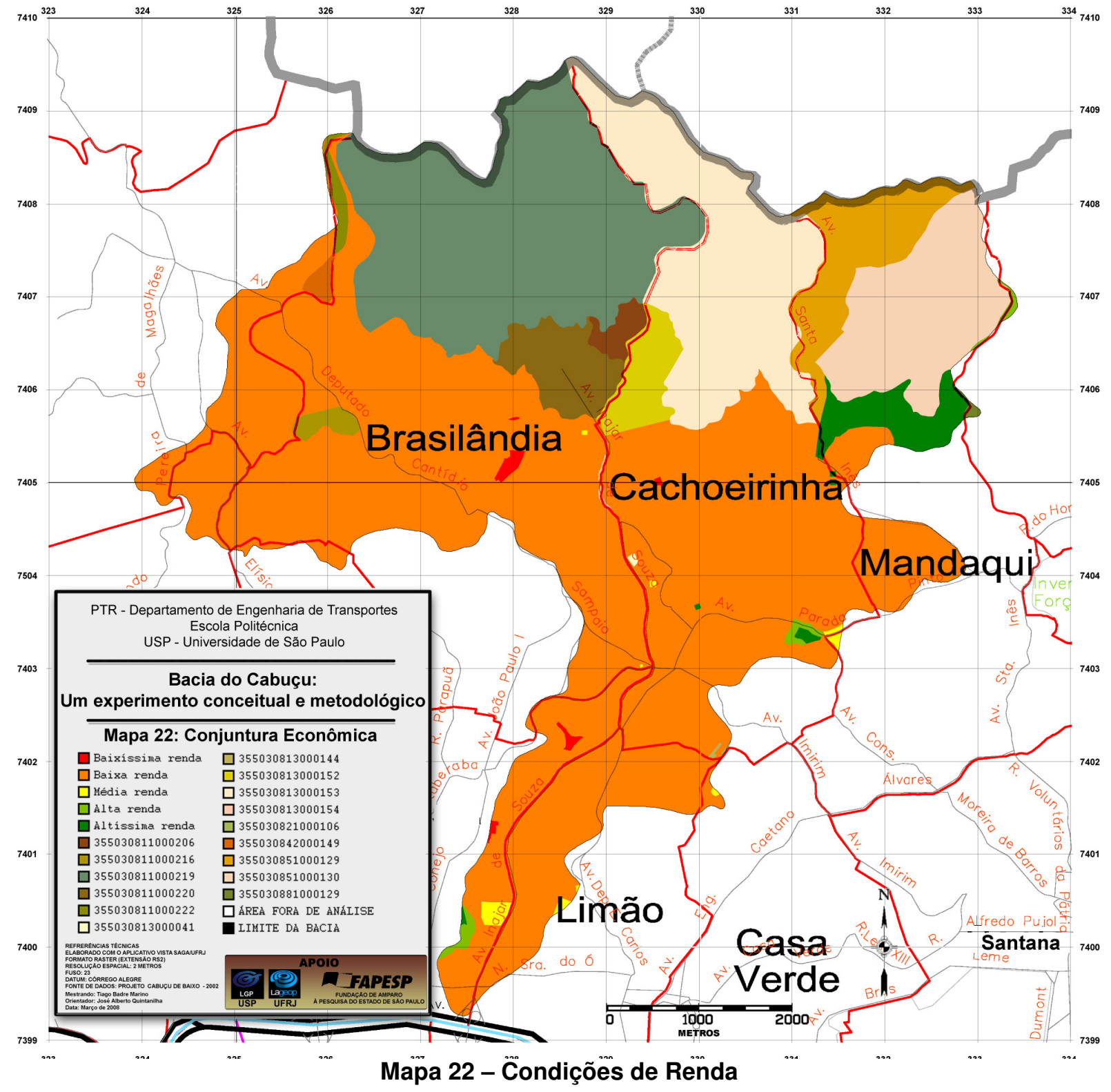




\subsection{Carta de Qualidade de Vida / Assentamentos Precários}

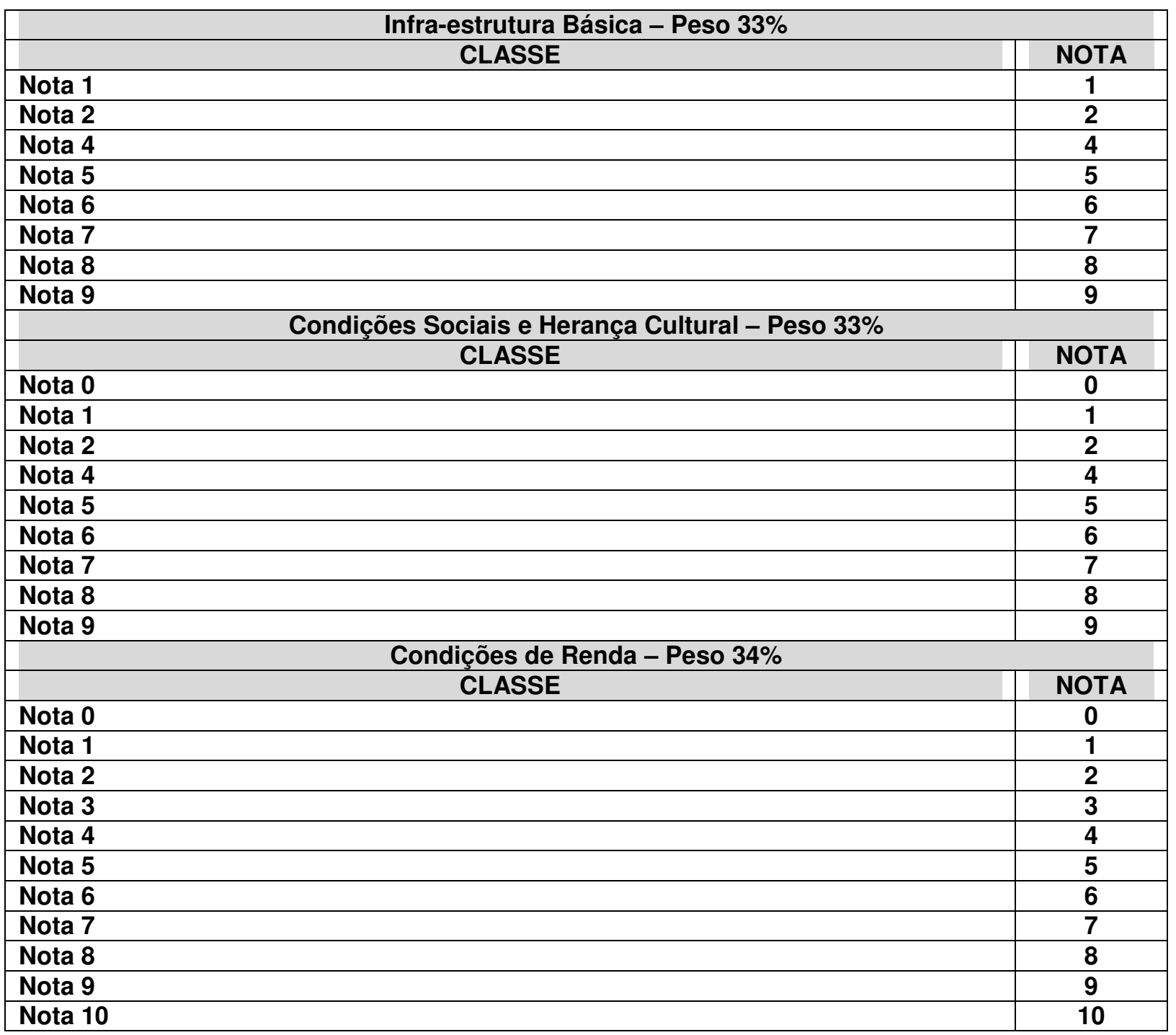

Quadro 5.6 - Pesos e notas atribuídos aos parâmetros para Qualidade de Vida / Assentamentos Precários 


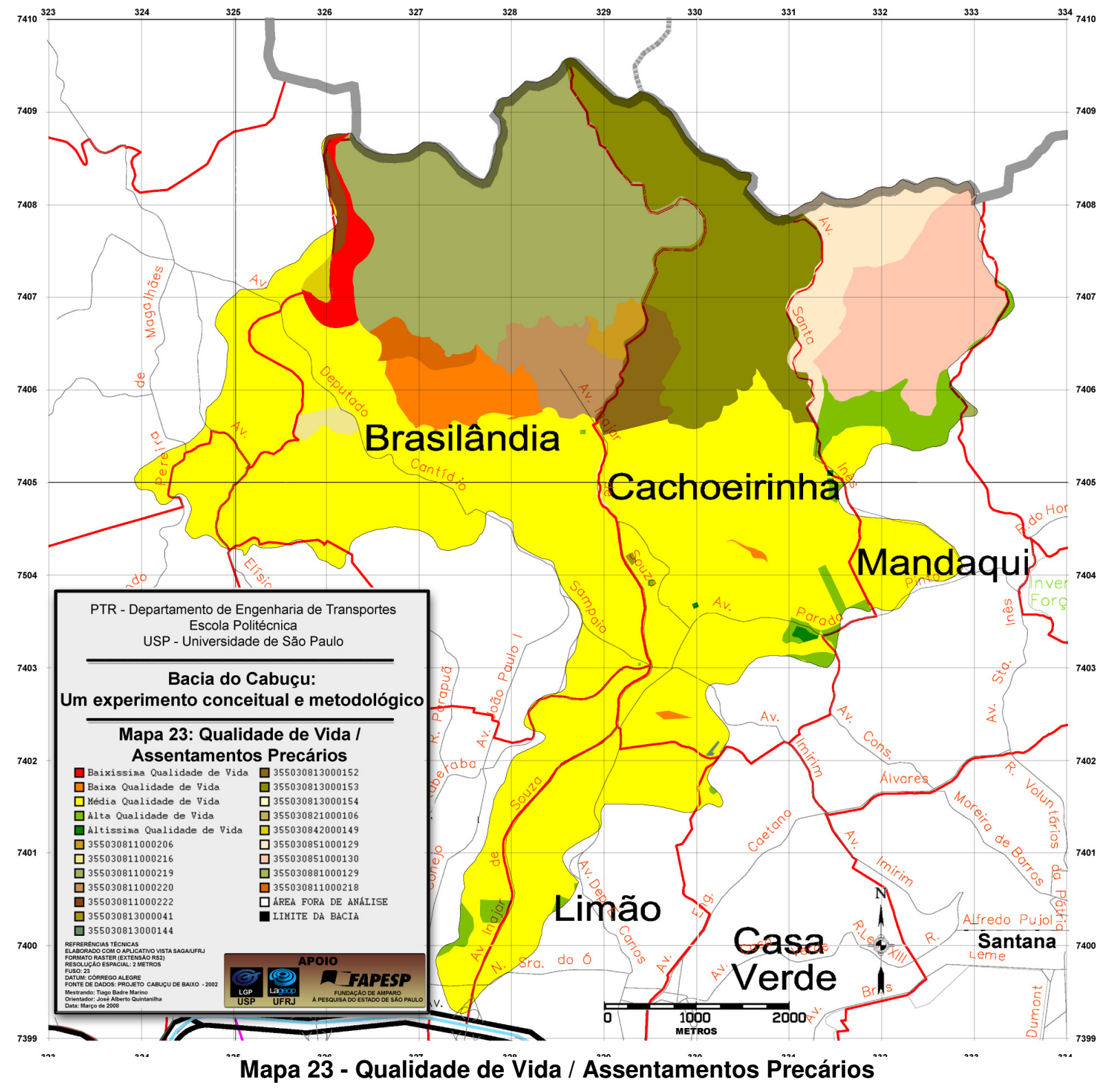




\subsection{Carta de Áreas Críticas para Riscos de Deslizamentos e Desmoronamentos}

Como entrada para esta Análise Geotopológica foram utilizados os mapas de "Qualidade de Vida/Assentamentos Precários" e "Riscos de Deslizamentos e Desmoronamentos - RDD", sendo o primeiro mapa, apresentando cinco legendas: baixíssimo, baixo, médio, alto e altíssimo risco. Já o segundo mapa apresenta quatro legendas: baixa, média, alta e altíssima Qualidade de Vida. Nota-se, portanto, que não foram mapeados setores de baixíssima qualidade de vida, de acordo com os parâmetros selecionados nesta aplicação metodológica.

Vale lembrar que as Avaliações Ambientais produzem mapeamentos de riscos/potenciais compostos por classes entre zero e dez, onde a classe "Nota 0" representa localidades de menor risco/potencial e a classe "Nota 10" representa as localidades de mais elevado risco/potencial para ocorrência do evento analisado.

Os agrupamentos das classes de avaliação foram destinados meramente à exibição dos mapas, para fins de simplificação na inspeção do analista. Para utilização em cômputos estão preservados os dados não aglutinados, sendo estes últimos os utilizados nas avaliações por apresentarem maior riqueza taxonômica.

A seguir apresenta-se o quadro de agrupamentos realizados.

\begin{tabular}{|c|c|}
\hline Classe & Risco/Potencia \\
\hline $\begin{array}{c}\text { Nota 0 } \\
\text { Nota 1 } \\
\text { Nota 2 }\end{array}$ & Baixíssimo \\
\hline $\begin{array}{c}\text { Nota 3 } \\
\text { Nota 4 }\end{array}$ & Baixo \\
\hline $\begin{array}{l}\text { Nota 5 } \\
\text { Nota 6 }\end{array}$ & Médio \\
\hline $\begin{array}{l}\text { Nota 7 } \\
\text { Nota 8 }\end{array}$ & Alto \\
\hline $\begin{array}{c}\text { Nota 9 } \\
\text { Nota 10 }\end{array}$ & Altíssimo \\
\hline
\end{tabular}

Quadro 5.7 - Agrupamentos de classes resultantes de avaliação 
Por saída gerou-se a carta de "Áreas Críticas para RDD", cujas legendas apresentam-se no formato, conforme disposto na figura a seguir:

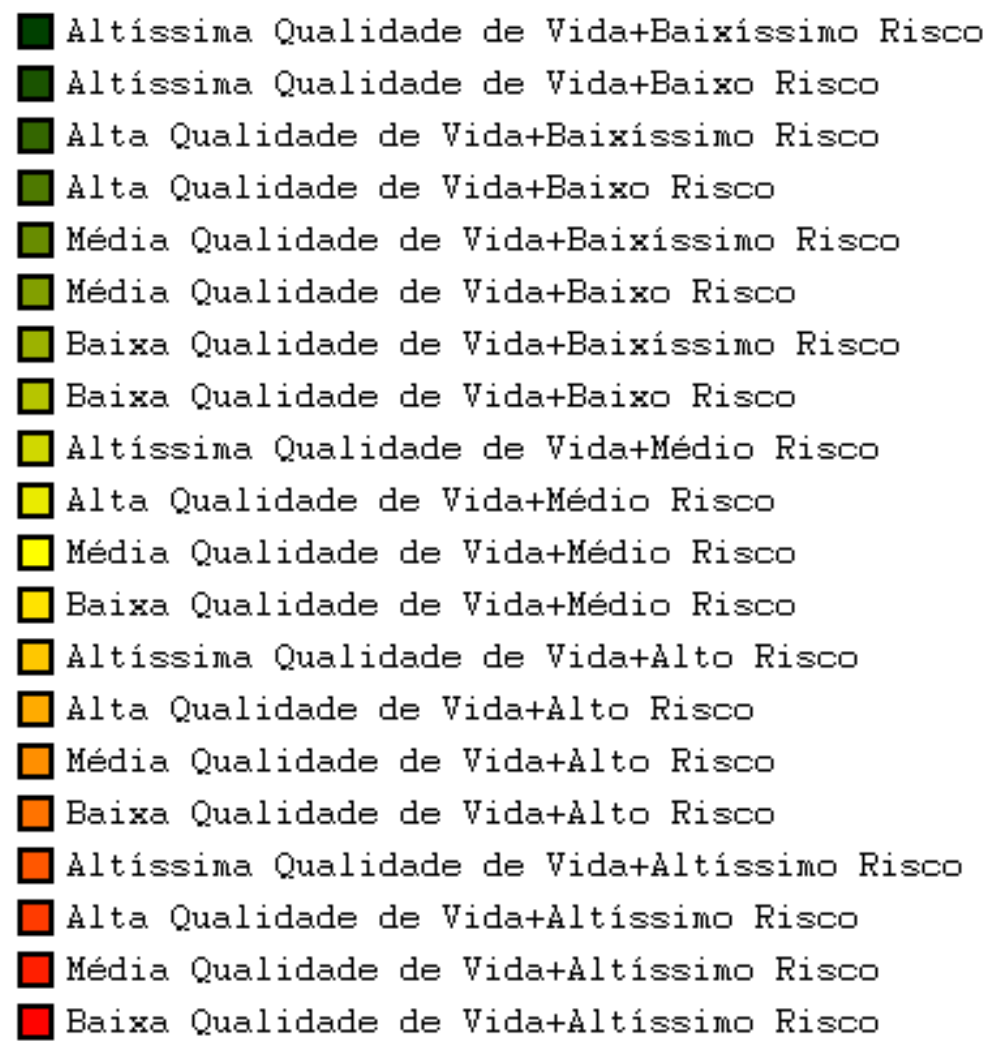

Figura 5.1 - Classes resultantes da combinação entre Qualidade de Vida X RDD

Analisando a escala cromática atribuída ao mapa resultante, destacam-se as seguintes tonalidades:

Verde: atribuída a classes cuja combinação mapeou localidades onde a qualidade de vida é considerada alta, ao passo que os riscos de ocorrência de deslizamentos são considerados baixos para estas mesmas localidades.

Amarelo: representada por ocasiões cujo nível de criticidade é considerado médio, ou seja, localidades cuja qualidade de vida é considerada média e os riscos também se apresentam em torno do grau médio.

Vermelho: representa as classes mais importantes nesta análise, cuja qualidade de vida é considerada baixa, de acordo com a classificação do IBGE e ao mesmo tempo encontra-se em áreas de elevados riscos de ocorrências de deslizamentos, salvo as primeiras classes desta tonalidade, que são representadas pelas localidades de elevada qualidade de vida, porém que também se situam em áreas de elevado risco. Estes, apesar de não serem considerados assentamentos precários, também devem ser analisados com atenção pois, independente da classe social, estão localizados sob área de elevado risco. 
O mesmo procedimento foi utilizado para se obter a carta de "Áreas Críticas para Riscos de Enchentes", alterando-se apenas o segundo parâmetro de entrada pela carta de "Riscos de Enchentes - RE".

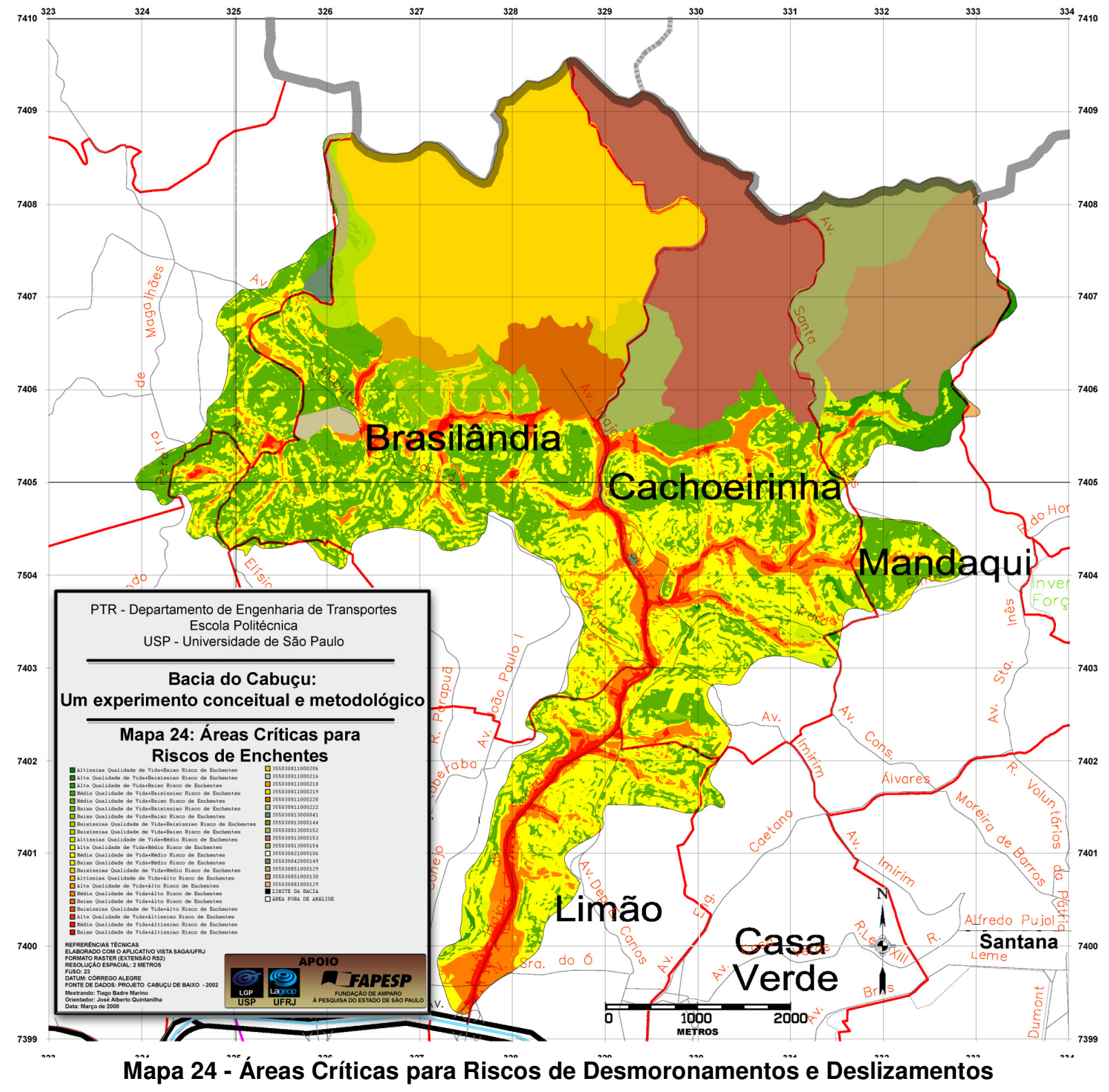

\begin{tabular}{|l|c|c|}
\hline \multicolumn{1}{|c|}{ Classe } & Área (Ha) & $\%$ Área \\
\hline MÉDIA QUALIDADE DE VIDA + ALTO RDD & 1252,0988 & $51,903 \%$ \\
\hline MÉDIA QUALIDADE DE VIDA + MÉDIO RDD & 601,4908 & $24,934 \%$ \\
\hline MÉDIA QUALIDADE DE VIDA + BAIXO RDD & 207,9020 & $8,618 \%$ \\
\hline MÉDIA QUALIDADE DE VIDA + BAIXÍSSIMO RDD & 76,4928 & $3,171 \%$ \\
\hline ALTA QUALIDADE DE VIDA + ALTO RDD & 55,5324 & $2,302 \%$ \\
\hline BAIXA QUALIDADE DE VIDA + ALTO RDD & 52,0520 & $2,158 \%$ \\
\hline ALTA QUALIDADE DE VIDA + MÉDIO RDD & 47,3304 & $1,962 \%$ \\
\hline BAIXÍSSIMA QUALIDADE DE VIDA + ALTO RDD & 33,9152 & $1,406 \%$ \\
\hline BAIXA QUALIDADE DE VIDA + MÉDIO RDD & 33,2744 & $1,379 \%$ \\
\hline MÉDIA QUALIDADE DE VIDA + ALTÍSSIMO RDD & 13,3892 & $0,555 \%$ \\
\hline
\end{tabular}




\begin{tabular}{|l|c|c|} 
BAIXA QUALIDADE DE VIDA + BAIXO RDD & 10,8268 & $0,449 \%$ \\
\hline BAIXÍSSIMA QUALIDADE DE VIDA + MÉDIO RDD & 9,5804 & $0,397 \%$ \\
\hline ALTA QUALIDADE DE VIDA + BAIXO RDD & 7,1200 & $0,295 \%$ \\
\hline ALTA QUALIDADE DE VIDA + BAIXÍSSIMO RDD & 4,3604 & $0,181 \%$ \\
\hline BAIXA QUALIDADE DE VIDA + BAIXÍSSIMO RDD & 2,1872 & $0,091 \%$ \\
\hline ALTíSSIMA QUALIDADE DE VIDA+MÉDIO RDD & 2,0388 & $0,085 \%$ \\
\hline ALTíSSIMA QUALIDADE DE VIDA + ALTO RDD & 1,1052 & $0,046 \%$ \\
\hline ALTIÍSSIMA QUALIDADE DE VIDA + BAIXO RDD & 0,6656 & $0,028 \%$ \\
\hline BAIXÍSSIMA QUALIDADE DE VIDA + BAIXO RDD & 0,6388 & $0,027 \%$ \\
\hline BAIXA QUALIDADE DE VIDA + ALTíSSIMO RDD & 0,3408 & $0,014 \%$ \\
\hline BAIXÍSSIMA QUALIDADE DE VIDA + ALTÍSSIMO RDD & 0,0212 & $0,001 \%$ \\
\hline ALTíSSIMA QUALIDADE DE VIDA + BAIXÍSSIMO RDD & 0,0004 & $0,000 \%$ \\
\hline
\end{tabular}

Quadro 5.8 - Planimetria da Carta de Áreas Críticas para Riscos de Desmoronamentos e Deslizamentos 


\subsection{Carta de Áreas Críticas para Riscos de Enchentes}

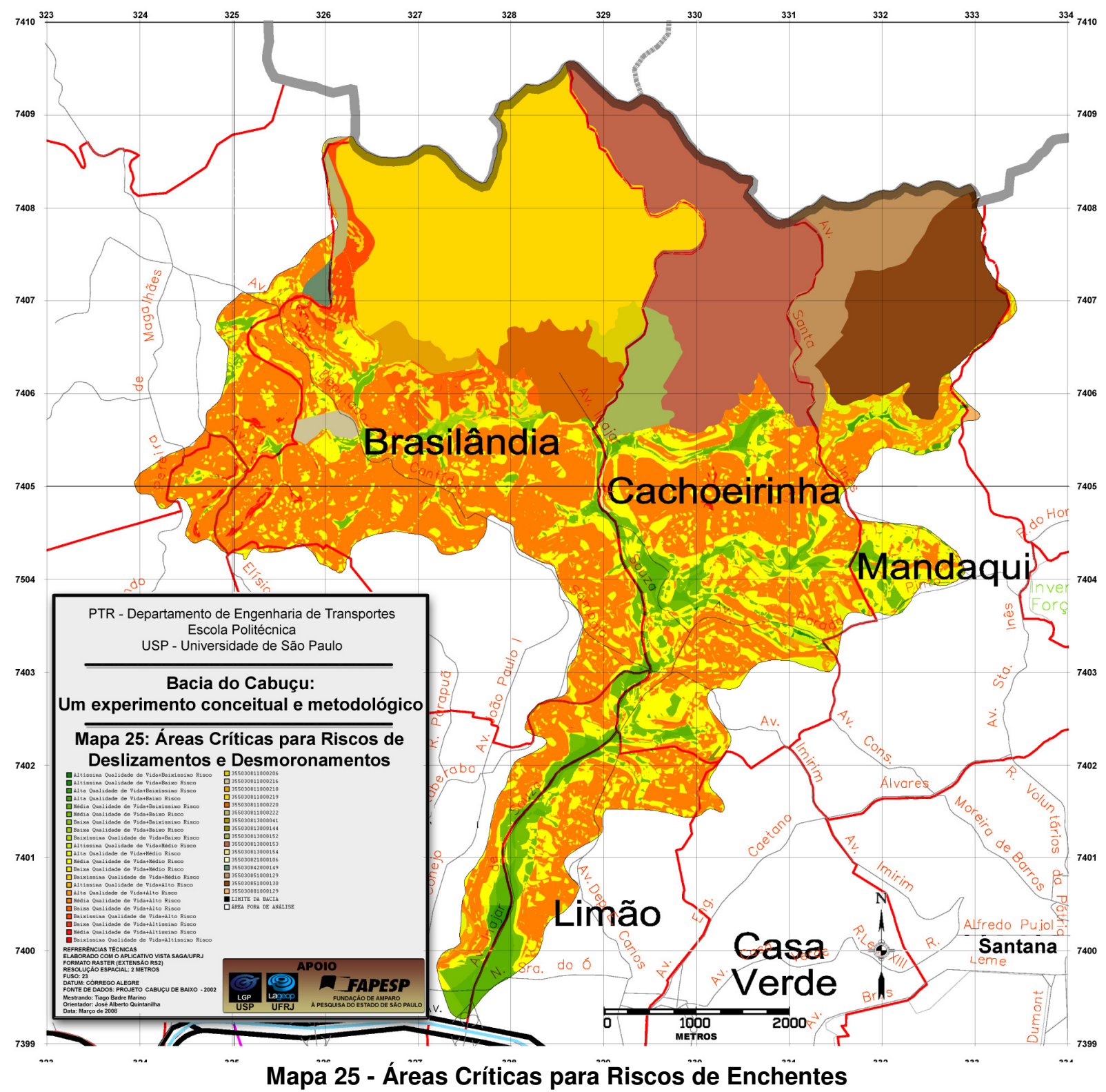

\begin{tabular}{|l|c|c|}
\hline \multicolumn{1}{|c|}{ Classe } & Área (Ha) & $\%$ Área \\
\hline MÉDIA QUALIDADE DE VIDA + MÉDIO RE & 983,5768 & 40,7723 \\
\hline MÉDIA QUALIDADE DE VIDA + BAIXO RE & 791,6936 & 32,8182 \\
\hline MÉDIA QUALIDADE DE VIDA + ALTO RE & 275,8744 & 11,4359 \\
\hline MÉDIA QUALIDADE DE VIDA + ALTÍSSIMO RE & 89,5424 & 3,7118 \\
\hline BAIXA QUALIDADE DE VIDA + BAIXO RE & 62,8880 & 2,6069 \\
\hline ALTA QUALIDADE DE VIDA + BAIXO RISCO RE & 53,1968 & 2,2052 \\
\hline ALTA QUALIDADE DE VIDA + MÉDIO RE & 47,2212 & 1,9575 \\
\hline BAIXÍSSIMA QUALIDADE DE VIDA + BAIXO RE & 36,6472 & 1,5191 \\
\hline BAIXA QUALIDADE DE VIDA + MÉDIO RE & 22,5900 & 0,9364 \\
\hline MÉDIA QUALIDADE DE VIDA + BAIXÍSSIMO RE & 10,6864 & 0,4430 \\
\hline ALTA QUALIDADE DE VIDA + ALTO RE & 9,2284 & 0,3825 \\
\hline BAIXA QUALIDADE DE VIDA + ALTO RE & 8,1180 & 0,3365 \\
\hline BAIXÍSSIMA QUALIDADE DE VIDA + BAIXÍSSIMO RE & 5,8620 & 0,2430 \\
\hline BAIXA QUALIDADE DE VIDA + ALTÍSSIMO RE & 3,7792 & 0,1567 \\
\hline
\end{tabular}




\begin{tabular}{|l|l|l|} 
ALTÍSSIMA QUALIDADE DE VIDA + MÉDIO RE & 2,7516 & 0,1141 \\
\hline ALTA QUALIDADE DE VIDA + ALTÍSSIMO RE & 2,7088 & 0,1123 \\
\hline ALTA QUALIDADE DE VIDA + BAIXÍSSIMO RE & 1,9880 & 0,0824 \\
\hline BAIXÍSSIMA QUALIDADE DE VIDA + MÉDIO RE & 1,5988 & 0,0663 \\
\hline BAIXA QUALIDADE DE VIDA + BAIXÍSSIMO RE & 1,3060 & 0,0541 \\
\hline ALTÍSSIMA QUALIDADE DE VIDA + BAIXO RE & 0,9820 & 0,0407 \\
\hline ALTIISSIMA QUALIDADE DE VIDA + ALTO RE & 0,0764 & 0,0032 \\
\hline BAIXÍSSIMA QUALIDADE DE VIDA + ALTO RE & 0,0476 & 0,0020 \\
\hline
\end{tabular}

Quadro 5.9 - Planimetria da Carta de Áreas Críticas para Riscos de Enchentes

\subsection{Carta de Áreas Indicadas para Transposições}

Para a avaliação do potencial de urbanização da Bacia, foram levados em conta:

- Fatores Topográficos: para declividades menos acentuadas são atribuídas maiores notas, uma vez que o risco de ocorrências de deslizamentos aumenta de acordo com acentuação dos aclives. A hipsometria é levada em conta devido à dificuldade de acesso que se cria, pela ausência de vias, em função da elevação.

- Fatores Antrópicos: O mapeamento de "Uso do Solo e Cobertura Vegetal" considera o tipo de ocupação atual, atribuindo-se notas mais elevadas para áreas sem ocupação como, por exemplo, a classe "Áreas vagas sem vegetação". A consideração do parâmetro "Proximidades de Superfícies Líquidas", se dá pelo fato de quanto menor a distância da rede de drenagem, maior o risco de ocorrência de enchentes. Para proximidades de rede viária, são consideradas melhores, as localidades mais próximas das vias de acesso, recebendo estas maiores notas.

- Fatores Geológicos: A geologia e geomorfologia analisam os tipos de rochas firmes e solos favoráveis à construção de moradias. Solos arenosos, argilosos, várzeas, picos e espigões são inviáveis para a antropização.

\begin{tabular}{|l|c|}
\hline \multicolumn{2}{|c|}{ Uso do Solo e Cobertura Vegetal - Peso 13\% } \\
\hline \multicolumn{1}{|c|}{ CLASSE } & NOTA \\
\hline Arruamento & BLOQUEADO \\
\hline Arruamento sem asfalto & BLOQUEADO \\
\hline Cemitério & 0 \\
\hline Clubes de campo & 0 \\
\hline Comércio e serviços & 0 \\
\hline Conjuntos residenciais & 0 \\
\hline Edificações & 0 \\
\hline Equipamentos públicos & 0 \\
\hline Indústrias e depósitos & 0 \\
\hline Lagoas de detenção temporária & 0 \\
\hline
\end{tabular}




\begin{tabular}{|c|c|}
\hline Limite da bacia & BLOQUEADA \\
\hline Loteamentos desocupados com vegetação & 10 \\
\hline Loteamentos desocupados sem vegetação & 10 \\
\hline Ocupação densa irregular & 0 \\
\hline Ocupação densa regularizada & $\mathbf{0}$ \\
\hline Área de proteção legal & 0 \\
\hline Área florestal & $\mathbf{0}$ \\
\hline Área fora de análise & BLOQUEADA \\
\hline Áreas com vegetação & 7 \\
\hline Áreas sem vegetação & 10 \\
\hline Áreas vagas com vegetação & 10 \\
\hline Áreas vagas sem vegetação & 10 \\
\hline Áreas verdes urbanas & 6 \\
\hline \multicolumn{2}{|c|}{ Declividades - Peso $22 \%$} \\
\hline CLASSE & NOTA \\
\hline $0-0.58$ & 10 \\
\hline $0.58-1.15$ & 10 \\
\hline $1.15-2.3$ & 10 \\
\hline $2.3-2.86$ & 10 \\
\hline $2.86-4.57$ & 9 \\
\hline $4.57-5.14$ & 9 \\
\hline $5.71-8.5$ & 9 \\
\hline $5.14-5.71$ & 9 \\
\hline $8.5-11.3$ & 9 \\
\hline $11.3-14.03$ & 8 \\
\hline $14.03-26.56$ & 7 \\
\hline $26.56-45$ & 5 \\
\hline $45-63.43$ & 3 \\
\hline $63.43-90$ & 1 \\
\hline Limite da bacia & BLOQUEADA \\
\hline Área fora de análise & BLOQUEADA \\
\hline Área expandida & BLOQUEADA \\
\hline \multicolumn{2}{|c|}{ Hipsometria - Peso 5\% } \\
\hline CLASSE & NOTA \\
\hline $715-815 M$ & 10 \\
\hline $815-905 \mathrm{M}$ & 6 \\
\hline $905-965 \mathrm{M}$ & 5 \\
\hline $965-1005 M$ & 4 \\
\hline $1005-1105 \mathrm{M}$ & 3 \\
\hline $1105-1190 \mathrm{M}$ & 2 \\
\hline $1190-1205 \mathrm{M}$ & 1 \\
\hline $1205-1215 \mathrm{M}$ & 0 \\
\hline Fundo & BLOQUEADA \\
\hline Limite da bacia & BLOQUEADA \\
\hline Área fora de análise & BLOQUEADA \\
\hline \multicolumn{2}{|c|}{ Geologia - Peso 13\% } \\
\hline CLASSE & NOTA \\
\hline Área fora de análise & BLOQUEADA \\
\hline Limite da bacia & BLOQUEADA \\
\hline Dep.leques aluviais & 5 \\
\hline Dep.sed.aluvionares & 5 \\
\hline Micaxistos e quartzitos & 10 \\
\hline Rochas graníticas & 10 \\
\hline Rochas metacarbonáticas & 10 \\
\hline \multicolumn{2}{|c|}{ Geomorfologia - Peso $20 \%$} \\
\hline CLASSE & NOTA \\
\hline Área fora de análise & BLOQUEADA \\
\hline Limite da bacia & BLOQUEADA \\
\hline
\end{tabular}




\begin{tabular}{|c|c|}
\hline Colinas pequenas & 10 \\
\hline Morros & 10 \\
\hline Morros e montanhas & 6 \\
\hline Planícies fluviais & 8 \\
\hline Setores de encostas íngremes & 0 \\
\hline \multicolumn{2}{|c|}{ Proximidade de Rede Viária - Peso $14 \%$} \\
\hline CLASSE & NOTA \\
\hline Arruamento & BLOQUEADA \\
\hline Arruamento sem asfalto & BLOQUEADA \\
\hline$<10 \mathrm{~m}$ ruas $\mid 11 \mathrm{~m}$ a $20 \mathrm{~m}$ ruas $\mathrm{s} /$ asfalto & 10 \\
\hline$<10 \mathrm{~m}$ ruas $\mid>20 \mathrm{~m}$ ruas $\mathrm{s} /$ asfalto & 8 \\
\hline $11 \mathrm{~m}$ a $20 \mathrm{~m}$ ruas $\mid<10 \mathrm{~m}$ ruas $\mathrm{s} /$ asfalto & 8 \\
\hline $11 \mathrm{~m}$ a $20 \mathrm{~m}$ ruas $\mid 11 \mathrm{~m}$ a $20 \mathrm{~m}$ ruas $\mathrm{s} /$ asfalto & 9 \\
\hline $11 \mathrm{~m}$ a $20 \mathrm{~m}$ ruas $\mid>20 \mathrm{~m}$ ruas $\mathrm{s} /$ asfalto & 8 \\
\hline$>20 \mathrm{~m}$ ruas $\mid<10 \mathrm{~m}$ ruas $\mathrm{s} /$ asfalto & 7 \\
\hline$>20 \mathrm{~m}$ ruas $\mathrm{s} /$ asfalto $\mid 11 \mathrm{~m}$ a $20 \mathrm{~m}$ ruas $\mathrm{s} / \mathrm{a}$ & 7 \\
\hline$>20 \mathrm{~m}$ ruas $\mid>20 \mathrm{~m}$ ruas $\mathrm{s} /$ asfalto & 4 \\
\hline Limite da bacia & BLOQUEADA \\
\hline Área fora de análise & BLOQUEADA \\
\hline \multicolumn{2}{|c|}{ Proximidade de Superfícies Líquidas - Peso $10 \%$} \\
\hline CLASSE & NOTA \\
\hline Piscinões & BLOQUEADA \\
\hline Até $20 \mathrm{~m}$ piscinões & 0 \\
\hline Até $50 \mathrm{~m}$ piscinões & 3 \\
\hline Drenagem & BLOQUEADA \\
\hline Até 20m drenagem & 0 \\
\hline De $20 \mathrm{~m}$ a $50 \mathrm{~m}$ drenagem & 3 \\
\hline De $50 \mathrm{~m}$ a $100 \mathrm{~m}$ drenagem & 6 \\
\hline$>50 \mathrm{~m}$ piscinões e > 100m drenagem & 10 \\
\hline Limite da bacia & BLOQUEADA \\
\hline Área fora de análise & BLOQUEADA \\
\hline
\end{tabular}

Quadro 5.10 - Pesos e notas atribuídos aos parâmetros para Áreas Indicadas para Transposições 


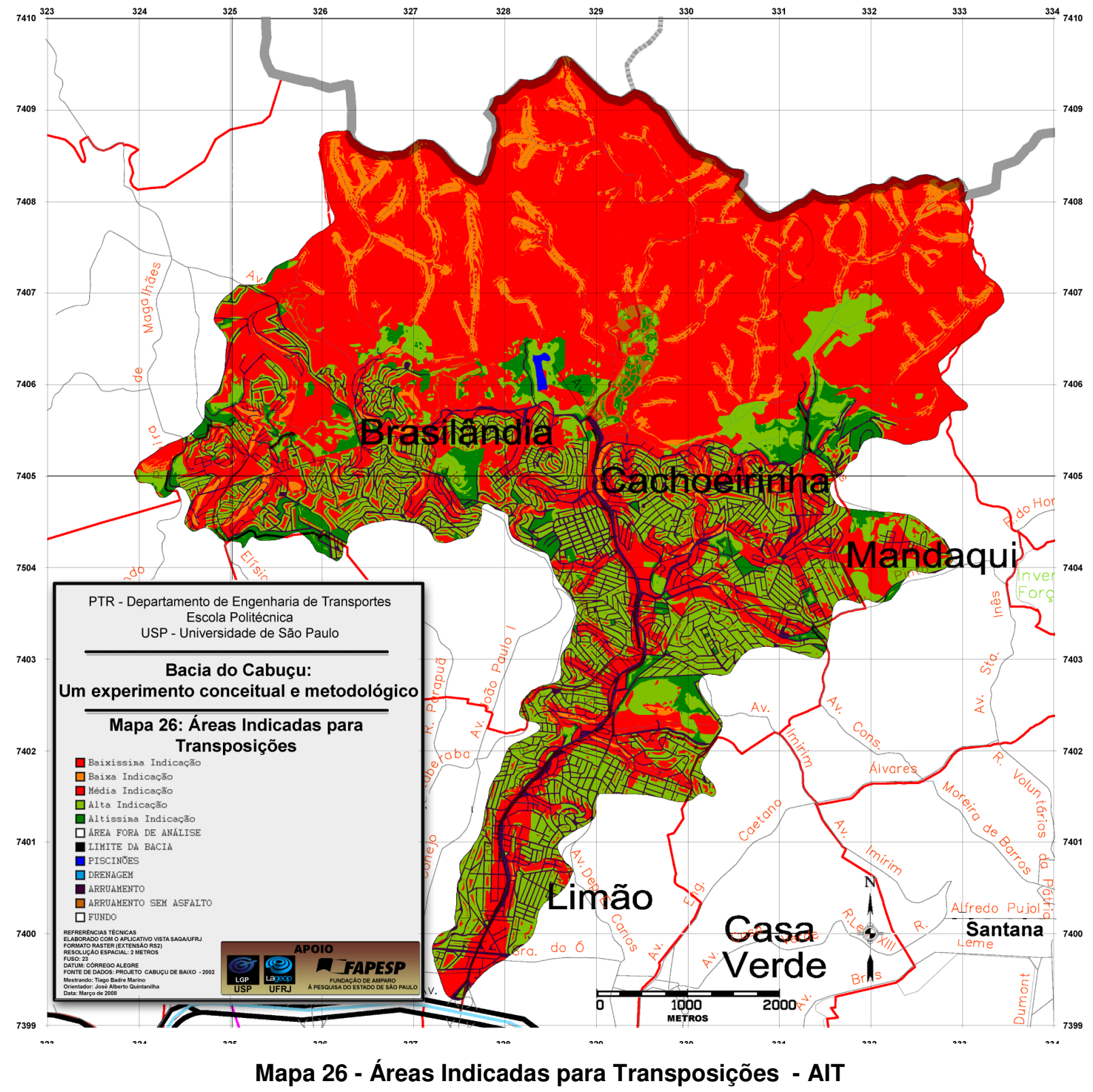




\subsection{Carta de Transposições para Riscos de Enchentes}

A elaboração da carta de Transposições para Riscos de Enchentes deu-se por meio da sobreposição entre o "Mapa 26 - Áreas Indicadas para Transposições AIT" e "Mapa 25 - Áreas Críticas para Riscos de Enchentes".

A partir do resultado deste cruzamento, por meio de Análises Geotopológicas, foram identificadas as ocorrências conjuntas das áreas indicadas para transposições (no Mapa 26) sobre as áreas críticas para enchentes, ou seja, onde altos riscos de ocorrências de enchentes coincidam com áreas de baixa qualidade de vida (no Mapa 25). Procedimento análogo foi adotado para a elaboração do Mapa 28 Transposições para Riscos de Desmoronamentos e Deslizamentos.

Através da inspeção visual do Mapa 28 é possível identificar não somente as localidades favoráveis à transposição, mas também a ocorrência destas áreas próximas às residências situadas em áreas críticas, com o objetivo de se respeitar um limite mínimo de distância para as transposições, a fim de evitar impactos econômicos e sociais nas famílias envolvidas após o processo. Este fator facilita enormemente na relação com a população afetada, uma vez que estas famílias serão deslocadas para áreas, consideradas seguras e próximas de seu ciclo social.

A figura a seguir ilustra as classes geradas na Carta de Transposições para Riscos de Enchentes. 


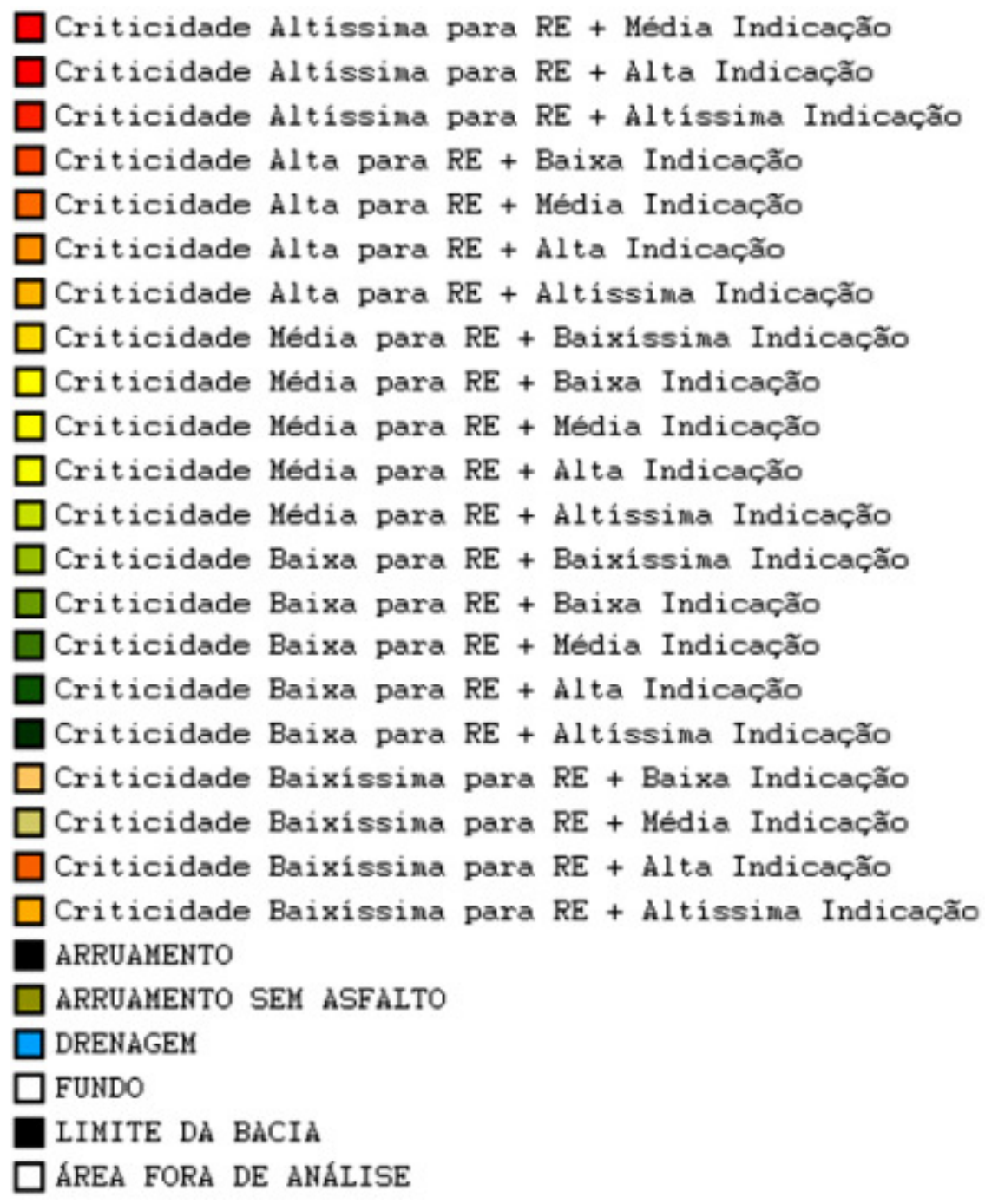

Figura 5.2 - Classes resultantes da Carta de Transposições para Riscos de Enchentes 


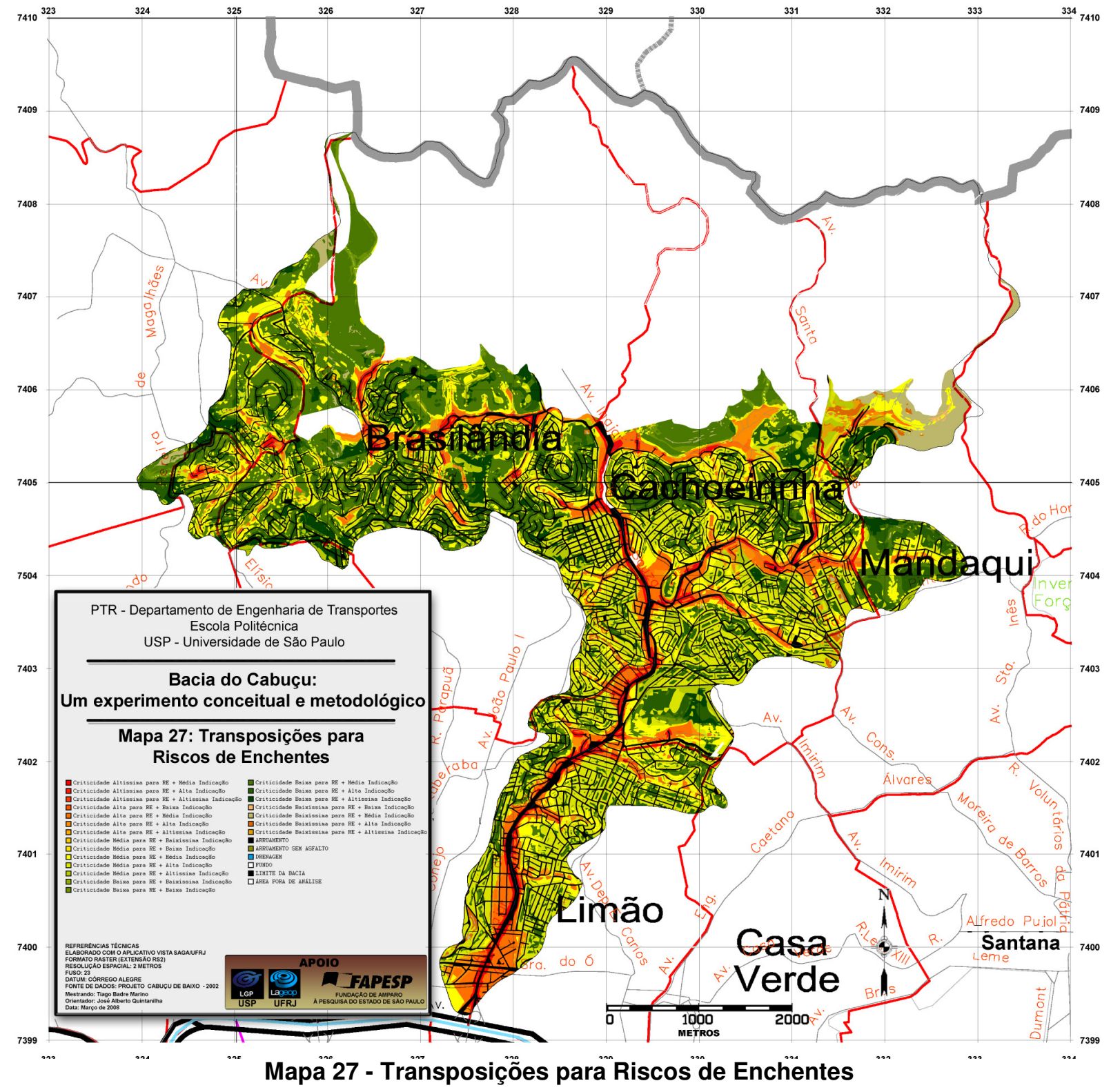




\subsection{Carta de Transposições para Riscos de Desmoronamentos e Deslizamentos}

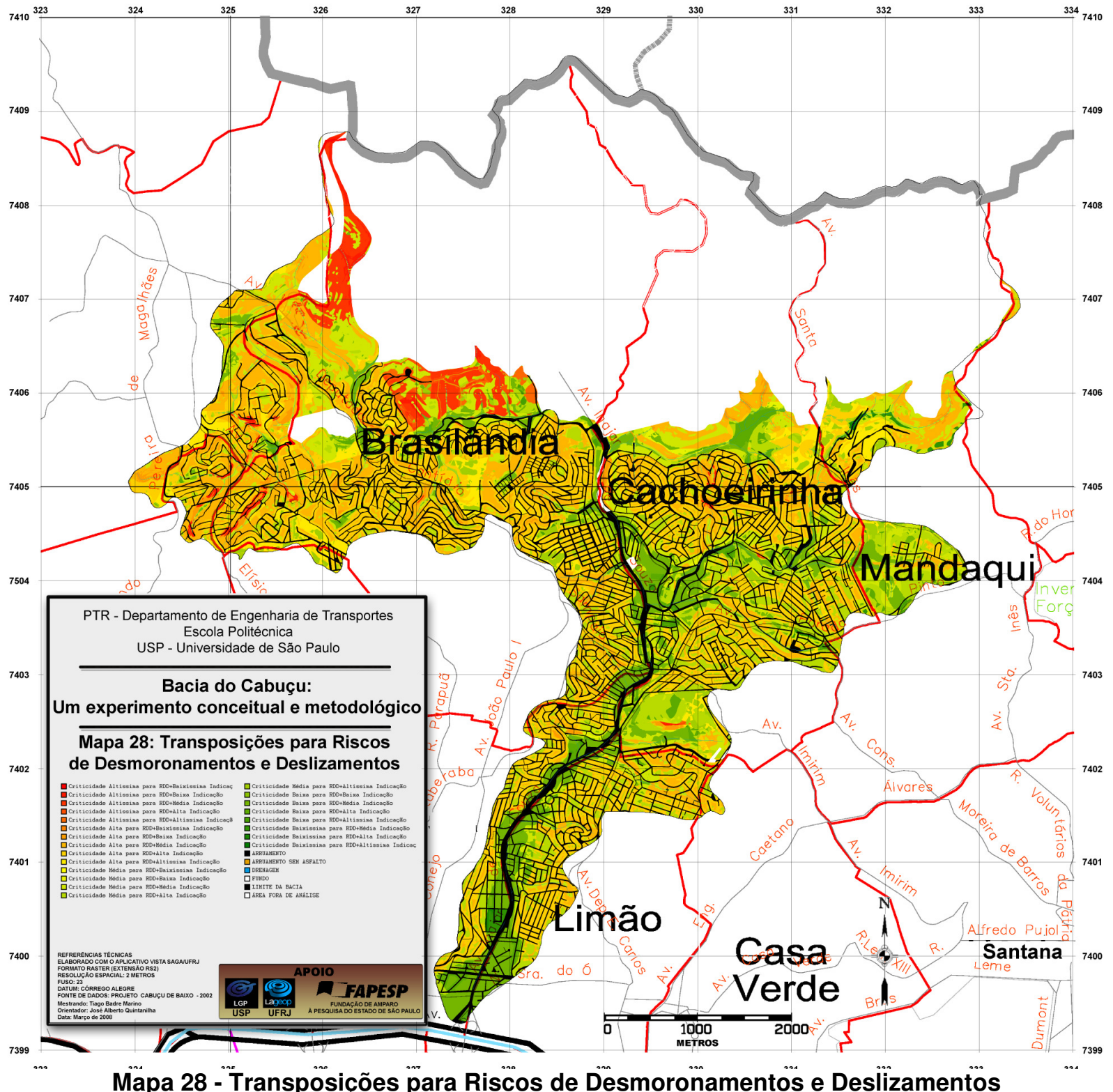

Mapa 28 - Transposições para Riscos de Desmoronamentos e Deslizamentos 


\section{VALIDAÇÃO}

Para fins de validação da metodologia apresentada neste trabalho, foi realizado o cotejamento dos mapeamentos de riscos com o histórico de ocorrências de enchentes e desmoronamentos, representados por pontos georreferenciados, coletados pelo Instituto de Pesquisas Tecnológicas - IPT até o ano de 2.002.

Como estratégia foi criou um índice, que leve em conta não apenas os acertos, mas também os erros, ponderando-os de acordo com o grau (conseqüência) dos acertos e erros dos mapeamentos oriundos da análise em laboratório.

Trata-se de um método de validação baseado em Matriz de Confusão (Confusion Matrix), adaptado a partir de RAMALHO (2003).

\subsection{Tabela de Pontuação}

Com o objetivo de experimentar a coincidência do histórico de ocorrências de enchentes e deslizamentos mapeados sobre o grau de risco analisado, cada um dos dois eventos originou uma tabela de pontuação, relatando a quantidade de eventos reais ocorridos sobre cada um dos riscos avaliados, de acordo com o nível de criticidade de cada incidência (definido no Quadro 6.1). Procedimento análogo foi também realizado para a validação da análise das "Áreas Indicadas para Transposições - AIT", através da verificação da incidência do histórico pontual de ambas ocorrências (enchentes e deslizamentos) sobre o nível de indicação para transposição indicada sob aqueles pontos. No cruzamento das linhas e colunas do Quadro 6.2 foram quantificadas as incidências das ocorrências reais para cada grau de risco: altíssimo, alto, médio, baixo e baixíssimo (definidos no "Mapa 18 - Riscos de Enchentes e Mapa 19 - Riscos de Deslizamentos/Desmoronamentos).

Tomando por ilustração o histórico de enchentes, o número total da amostragem para este teste será a quantidade de eventos enchentes ocorridas na bacia, mapeadas pelo Instituto de Pesquisas Tecnológicas (14 ocorrências de enchentes).

\subsection{Grau de gravidade dos erros}

Visando ponderar a gravidade dos erros de mapeamento produzidos pela aplicação da metodologia, foi criado um índice ponderado. Por exemplo, identificar um caso de enchente incidente em área mapeada como grau de risco baixíssimo é muito mais crítico que identificar como uma ocorrência em área mapeada como grau 
de risco altíssimo. Enquanto o primeiro caso trata-se de um erro gravíssimo cometido pela aplicação metodológica, pois indica áreas com "de baixo risco" onde de fato ocorreram enchentes, no segundo caso, a metodologia aplicada atinge o objetivo, uma vez que indica, sem o conhecimento prévio do histórico de ocorrências, áreas de alto risco.

Foi então adotado um sistema de pesos de acordo com cada grau do acerto (ou erro) cometido pela aplicação metodológica, relacionados no quadro a seguir:

\begin{tabular}{|c|c|c|}
\hline Grup । & Pesı & Justificativa \\
\hline A1 & 3 & $\begin{array}{l}\text { Recebe bonificação em função do evento ter ocorrido de fato onde a área foi } \\
\text { considerada pela metodologia como a mais crítica (riscos altíssimos). }\end{array}$ \\
\hline A2 & 2 & $\begin{array}{l}\text { Também recebe bonificação, porém abaixo do anterior. Nestas áreas foram } \\
\text { registradas ocorrências sobre uma localidade mapeada com alta probabilidade de } \\
\text { ocorrência deste evento. }\end{array}$ \\
\hline A3 & 1 & $\begin{array}{l}\text { Último grau de aceitabilidade da metodologia. Trata-se de locais considerados } \\
\text { com probabilidade média de ocorrências dos eventos analisados. Como este em } \\
\text { terceiro na escala de gravidade recebe pontuação proporcional ao seu grau de } \\
\text { risco. }\end{array}$ \\
\hline E1 & -2 & $\begin{array}{l}\text { Caso ocorram registros de ocorrências reais de eventos nestas áreas, devem ser } \\
\text { penalizadas, proporcionalmente ao número de casos relatados, pois se trata de } \\
\text { localidades mapeadas pela metodologia com "áreas de baixa probabilidade de } \\
\text { ocorrência" do evento analisado. Sendo assim, um evento ocorrido nesta região } \\
\text { contraria a metodologia. }\end{array}$ \\
\hline E2 & -3 & $\begin{array}{l}\text { Sem dúvida este é o caso mais grave, onde se registram ocorrências de eventos } \\
\text { reais em áreas mapeadas pela metodologia como áreas de baixíssimo risco, ou } \\
\text { seja, de baixíssima probabilidade de ocorrência do evento. Portanto, cada evento } \\
\text { real que incida sobre essas áreas deve penalizar rigidamente a metodologia, } \\
\text { recebendo tal peso. }\end{array}$ \\
\hline
\end{tabular}

Quadro 6.1 - Grupos, pesos e justificativas das ponderações para o cálculo do Índice de Acerto Ponderado do teste de validação da metodologia

\section{3. Índice de Acerto Ponderado (IAP)}

As porcentagens de acertos e erros foram ponderadas, de acordo com os pesos atribuídos a cada grupo, conforme o Quadro 6.1. Os valores foram atribuídos visando aplicar um peso que penalize erros do tipo E2 e congratule acertos do tipo A1.

O modelo proposto é flexível a outras distribuições de peso, de acordo com a classificação do grau dos erros (gravidade da conseqüência ou sua dificuldade em ocorrer). 


$$
P t s_{o b t}=3 \times A_{1}+2 \times A_{2}+A_{3}-E_{1}-2 \times E_{2}
$$

À soma destes acertos e erros ponderados foi denominada IAP (Índice de Acerto Ponderado). Este conjunto de pesos pode ser alterado de acordo com a importância da aplicação. Em um caso, por exemplo, em que o erro grosseiro possa ser catastrófico, o valor atribuído à classe E2 aumentaria em detrimento dos demais. A formulação abaixo restringe o índice obtido a valores percentuais num intervalo de $0 \%$ a $100 \%$.

$$
I A P=\frac{P t s_{o b t}+\left|P t s_{\text {min }}\right|}{P t s_{\text {max }}+\left|P t s_{\text {min }}\right|}
$$

Pts $_{\text {obt }} \rightarrow$ Total de Pontos obtidos

Pts $_{\max } \rightarrow$ Pontuação Máxima

Pts $_{\min } \rightarrow$ Pontuação Mínima

\subsection{Cálculo dos Índices de Acertos Ponderados}

Tomando por exemplo a validação do mapeamento de riscos de enchentes (Quadro 6.2-A), multiplicou-se o número de casos do histórico de enchentes incidentes sobre cada grupo pelos seus respectivos pesos (definidos e justificados no Quadro 6.1), resultando na pontuação individual para cada grupo de acerto e erro. Pelo somatório do produto de cada um dos cinco grupos, determina-se a pontuação total de acertos e erros ponderados ("Total de Pontos").

A pontuação mínima que a validação para os riscos de enchentes pode alcançar, no caso em que todas as incidências de enchentes ocorram em áreas mapeadas como "risco altíssimo", é igual ao número total de casos (14), multiplicados pelo peso relacionado a este grau de acerto (3), resultando em 42 . De forma análoga, a pontuação mínima é obtida através do produto "total de número de casos (14) x peso para áreas de baixíssimo risco (-3)", resultando no valor -42 . Devido o fato dos pesos para os casos extremos de acertos e erros serem simétricos (3 e -3, respectivamente), o valor máximo que a pontuação pode alcançar também será simétrico ao valor mínimo, neste caso, 42 pontos.

Para a validação das análises de "Áreas Indicadas para Transposições" (Quadro 6.2-C), foram utilizados, como amostragem, os dados históricos de enchentes e deslizamentos, verificando as ocorrências destes casos sobre grau de 
favorabilidade das áreas para transposição. Uma elevada incidência da amostragem do teste sobre a classe de altíssima indicação à transposição compromete a qualidade da aplicação metodológica, uma vez que se trata de localidades com alta indicação para a transposição, mas que de fato sofreram os desastres analisados, contrariando o princípio da metodologia.

O motivo da quantidade de total de amostragem teste do Quadro 6.2-C não somar os 40 , referentes as 14 amostras de enchentes e 26 de deslizamentos e desmoronamentos se deu devido ao cruzamento de ocorrências de ambos eventos sobre o mapa de AITs resultar em 23 ocorrências pontuais incidentes sobre a classe "arruamento" deste mapa. Como esta classe não foi considerada nas análises conduzidas (foi bloqueada), uma vez que não há ocorrência de famílias e tampouco de áreas para transposições sobre as rodovias, restaram então 17 ocorrências para a amostragem efetiva da validação para esta análise.

\begin{tabular}{|c|c|c|c|c|c|c|}
\hline \multicolumn{7}{|c|}{ A - Enchentes } \\
\hline Grau de Risc, 1 & Casc s & Pes 0 & Pontuaçã o & $\%$ Tot: I & Taxa de Acerto & \\
\hline Altíssimo & 2 & 3 & 6 & $14,29 \%$ & Total de Pontos & 21 \\
\hline Alto & 6 & 2 & 12 & $42,86^{\circ}$, & Pontuação Máxima & 42 \\
\hline Médio & 5 & 1 & 5 & $35,71 \%$, & Pontuação Mínima & -42 \\
\hline Baixo & 1 & -2 & -2 & $7,14 \%$ & IAP - Índice de Acertos & $75,0 \%$ \\
\hline Baixíssimo & 0 & -3 & 0 & $0,00 \%$ & & \\
\hline Total & 14 & & 21 & $100,00 \%$ & & \\
\hline
\end{tabular}

\begin{tabular}{|c|c|c|c|c|c|c|}
\hline \multicolumn{7}{|c|}{ B - Deslizamentos e Desmoronamentos } \\
\hline Grau de Riscı! & Casc s & Pes 0 & Pontuaçã o & \% Tot: I & \begin{tabular}{|l} 
Taxa de Acerto \\
\end{tabular} & \\
\hline Altíssimo & 1 & 3 & 3 & $3,85 \%$ & Total de Pontos & 40 \\
\hline Alto & 18 & 2 & 36 & $69,23^{\circ} ;$ & Pontuação Máxima & 78 \\
\hline Médio & 5 & 1 & 5 & $19,23^{\circ}$, & Pontuação Mínima & -78 \\
\hline Baixo & 2 & -2 & -4 & $7,69 \%$ & IAP - Índice de Acertos & $75,6 \%$ \\
\hline Baixíssimo & 0 & -3 & 0 & $0,00 \%$ & & \\
\hline Total & 26 & & 40 & $100,00 \%$ & & \\
\hline
\end{tabular}

\begin{tabular}{|c|c|c|c|c|c|c|}
\hline \multicolumn{7}{|c|}{ C - Áreas Indicadas para Transposições - AIT } \\
\hline Favorabilidad & Casc s & Pes 0 & Pontuaçã o & \% Tot: I & Taxa de Acertc & \\
\hline Baixíssima & 07 & 3 & 0 & $0,00 \%$ & Total de Pontos & 16 \\
\hline Baixa & 2 & 2 & 4 & $11,76^{\circ}$, & Pontuação Máxima & 51 \\
\hline Média & 14 & 1 & 14 & $82,35^{\circ}$, & Pontuação Mínima & -51 \\
\hline Alta & 1 & -2 & -2 & $5,88 \%$ & IAP - Índice de Acertos & $65,7 \%$ \\
\hline Altíssima & 0 & -3 & 0 & $0,00 \%$ & & \\
\hline Total & 17 & & 16 & $100,00 \%$ & & \\
\hline
\end{tabular}

Quadro 6.2 - Cálculos dos Índices de Acertos Ponderados

- $\operatorname{IAP}($ Enchentes $)=[21+|-42|] /[42+|-42|]=63 / 84=0,7500$

- $\operatorname{IAP}(\mathrm{DD})=[40+|-78|] /[78+|-78|]=118 / 156=0,7564$

- $\operatorname{IAP}(\mathrm{AIT})=[16+|-51|] /[51+|-51|]=67 / 102=0,6568$ 


\section{CONCLUSÕES}

As avaliações ambientais apontaram os locais na Bacia do Córrego Cabuçu de Baixo onde a expansão urbana deve ser evitada, localidades estas, sujeitas a elevados riscos de enchentes e deslizamentos (conflitos potenciais), e por outro lado, também indicaram locais em que a expansão urbana poderá ser realizada sem problemas para a população e para o poder público, apontadas através da interpretação dos mapas de Indicações para Transposições de Áreas Críticas para Deslizamentos e Enchentes, a partir dos critérios utilizados no trabalho e apresentados na metodologia.

A metodologia de criação de mapeamentos de Qualidade de Vida na região também foi atestada por meio do "Mapa 23 - Qualidade de Vida / Assentamentos Precários", onde foram dissecados todos os temas sócio-econômicos, considerados por referências no assunto, imprescindíveis à determinação da qualidade de vida humana. Por complemento foi obtido também o mapeamento de Assentamentos Precários, ou seja, Baixa Qualidade de Vida, de acordo com o Índice de Desenvolvimento Humano (IPEA, 1998). A partir deste mapa foi realizada a análise geotopológica, por meio de combinação de mapas, processadas no aplicativo VISTA/SAGA, a fim de determinar a ocorrência de áreas críticas, ou seja, localidades onde sejam encontradas a ocorrência conjunta de assentamentos precários (baixa qualidade de vida) sobre áreas de alto risco de ocorrência de enchentes e deslizamentos. O resultado final foi apresentado por meio do "Mapa 24 - Áreas Críticas para Riscos de Desmoronamentos e Deslizamentos" e "Mapa 25 Áreas Críticas para Riscos de Enchentes".

Finalmente, a combinação destes dois últimos mapeamentos com o "Mapa 26 - Áreas Indicadas para Transposições - AIT", resultou o mapeamento de áreas possíveis para transposições de assentamentos precários. Através da interpretação visual do "Mapa 27 - Transposições para Riscos de Enchentes" e "Mapa 28 Transposições para Riscos de Desmoronamentos e Deslizamentos", pôde-se identificar áreas próximas, seguras para a transposição (alta indicação para transposição e baixo risco de enchente, desmoronamento e deslizamento), respeitando um limite de distância da localização de origem das famílias situadas em áreas críticas. Em áreas cujos assentamentos precários ocorram sob alto risco de enchentes e deslizamentos e não ocorram áreas próximas indicadas para 
realocação, sugere-se que sejam realizados investimentos em trabalhos de melhoria de infra-estrutura destes locais.

A obtenção dos mapeamentos finais de transposições indicadas para os riscos analisados, não só culminou na chegada do objetivo principal inicialmente proposto, mas também comprova a eficácia do aplicativo VISTA/SAGA como uma ferramenta de aplicação que viabiliza a condução da metodologia. Com a possibilidade de acesso ao código do programa, viabilizou-se a implementação das rotinas complementares, imprescindíveis à otimização e execução dos processos envolvidos. Como contribuição ao VISTA/SAGA, o aplicativo herda uma série de ferramentas, desenvolvidas ao longo deste trabalho, que potencializam ainda mais a capacidade analítica para a realização de análises de riscos.

A última etapa do estudo foi medir a qualidade das avaliações realizadas. Foi adotada a estratégia de criação de um índice de acertos e erros dos mapeamentos finais, através do cruzamento de histórico de ocorrências reais com os mapas de áreas críticas e indicações para transposições, ponderando os acertos e erros de acordo com seu grau de gravidade. Os índices de acertos alcançados na fase de validação, na faixa de $75 \%$ para Enchentes, Desmoronamentos e Deslizamentos e 66\% para Áreas Indicadas para Transposições, são considerados como satisfatórios, principalmente dado ao fato de que em todos os cotejamentos realizados não mapearam erros do tipo E2 (ocorrência de enchentes/deslizamentos em áreas avaliadas como "probabilidade baixíssima" de ocorrência dos mesmos), o que comprometeria fortemente a pontuação final.

Resultados mais satisfatórios podem ser obtidos quando as análises são guiadas por técnicos com experiências diferentes no assunto. Como o objetivo era apresentar a metodologia, neste trabalho as notas foram atribuídas, de acordo com os conhecimentos do autor, no que diz respeito a temas como geologia, geomorfologia, etc..

Objetivou-se, com o presente estudo, levantar caminhos simples para a aquisição de conhecimentos sobre estas condições ambientais precárias, gerando diagnósticos e prognósticos como elementos de apoio à decisão quanto à melhoria da qualidade de vida dos habitantes destas áreas urbanas problemáticas.

Em essência, foram levantados potenciais de utilização da área, juntamente com os riscos de eventos danosos, dentro do quadro de oportunidades e ameaças a estas áreas inseridas dentro do tecido urbano. 
Uma vez realizados estes estudos os conhecimentos adquiridos, pelo uso do Geoprocessamento, sobre a realidade ambiental urbana e problemática da Bacia do Córrego Cabuçu de Baixo poderão ser extrapolados, com as devidas precauções, para inúmeras outras áreas urbanas que possuem características semelhantes e enfrentam os mesmos problemas. 


\section{REFERÊNCIAS BIBLIOGRÁFICAS}

ATLAS. Atlas Ambiental do Município de São Paulo. 2002. Disponível em: <http://atlasambiental.prefeitura.sp.gov.br>. Acesso em: 20 de abril de 2006.

AZZONI, C.; MENEZES-FILHO, N.; MENEZES, T.; SILVEIRA NETO, R. Geografia e convergência da renda entre os estados brasileiros (cap. 11). In: HENRIQUES, R. (org). Desigualdade e pobreza no Brasil. IPEA, Rio de Janeiro. p. 299-343. 2000.

ARONOFF, S. Geographical Information Systems: A Management Perspective. Ottawa, WDI Publications, 1989. 294 p.

BARROS, M.T.L. Gerenciamento integrado de bacias hidrográficas em áreas urbanas. São Paulo: EPUSP, 2004. 52 p.

BID (BANCO INTERAMERICANO DE DESENVOLVIMENTO). Panorama dos Desastres Naturais na América Latina e Caribe. Washington, 2000.

BONHAM-CARTER, G.F. Geographic Information Systems for Geoscientists: modeling with GIS. ed. Pergamon, Ottawa, 1998. 398 p.

BURROUGH, P.A. Principles of Geographic Information Systems for Land Resources Assessment. Oxford, Oxford University Press, 1986. 193 p.

BURROUGH, P.A.; MCDONNELL, R. A. Principles of geographical information systems. Oxford, Oxford University Press, 1998. 327 p.

CAI, S.; CHAN, N.W.; KUNG, H.; LIU, P. Management of flood disasters in the Jianghan Plain. Disaster Prevention and Management, v. 10, n. 5, p. 339 - 348, 2001.

CALHEIROS, S. Q. C. Gerenciamento integrado para transferência e destino final dos resíduos sólidos urbanos de Maceió. Relatório Final Completo. Universidade Federal de Alagoas. Maceió, AL, 2004. 256p.

CÂMARA, G.; DAVIS, C.; MONTEIRO, A.M.V. Introdução à Ciência da Geoinformação. INPE, 2001. 345 p.

CÂMARA, G.; FREITAS, U.M. Perspectivas em Sistemas de Informação Geográfica. Disponível em: <http://www.dpi.inpe.br/gilberto/fatorgis95.pdf>. Acesso em 10 de julho de 2004.

CARVALHO, C.S.; GALVÃO, T. Prevenção de Riscos de Deslizamentos em Encostas: Guia para Elaboração de Políticas Municipais. Brasília: Ministério das Cidades; Cities Alliance, 2006. 111 p.

CARVALHO, C.S.; MACEDO, E.S; OGURA, A.T. Mapeamento de Riscos em Encostas e Margens de Rios. Ministério das Cidades; Instituto de Pesquisas Tecnológicas - IPT, São Paulo, 2007. 176p. 
CASTRO, S.M. Estratégias, Políticas e Práticas para Reduzir o Risco de Perigos Naturais e a Vulnerabilidade. Disaster Preparedness Management. San Jose, Costa Rica: 2001

CENTRO DE ESTUDOS DA METRÓPOLE. Base Cartográfica Digital do Município de São Paulo. Centro de Estudos da Metrópole. São Paulo, 2000.

Disponível em: <http://www.centrodametropole.org.br/base_cart.html>

COUCLELIS, H. People Manipulate Objects (but Cultivate Fields): Beyond the Raster-Vector Debate in GIS. In: Theories and Methods of Spatio-Temporal Reasoning in Geographic Space, Proceedings of the International Conference GIS - From Space to Territory: Theories and Methods of Spatio-Temporal Reasoning editado por A. U. Frank, I. Campari, U. Formentini, Lecture Notes in Computer Science, 639 (New York: Springer-Verlag), 1992, p. 65-77.

CORSEUIL, C.H.; FOGUEL, M.N. Uma sugestão de deflatores para rendas obtidas a partir de algumas pesquisas domiciliares do IBGE. IPEA, Texto para discussão Nº 897. Rio de Janeiro, 2002.

COWEN, D.J. GIS versus CAD versus DBMS: what are the differences. Photogrammetric Engineering and Remote Sensing, v. 54 n. 2. p. 1551-4, 1988.

DEFESA CIVIL JUIZ DE FORA - Disponível em <http://www.defesacivil.pjf.mg.gov.br/estatisticas.php>. Acesso em: 9 de novembro de 2007.

DEWAN, A.M.; KUMAMOTO, T.; NISHIGAKI, C. Flood Hazard Delineation in Greater Dhaka, Bangladesh Using an Integrated GIS and Remote Sensing Approach. Geocarto International, v. 21, n. 2, June 2006 , p. 33 - 38.

DUNNE, T.; LEOPOLD, L. Water in Environmental Planning. W.H. Freeman and Co. San Francisco. 1978.

EM-DAT - Emergency Events Database. The OFDA/CRED International Disaster Database. Disponível em: <http://www.em-dat.net>. Consultado em: 2 de março de 2007.

ESRI. Understanding GIS - Self-Study Workbook. Redlands, CA, US: Environmental Systems Research Institute, Inc., 1990. 600 p.

FERNANDES, R. Desigualdade salarial: aspectos teóricos (cap. 1). In: IPEA. Estrutura salarial - Aspectos conceituais e novos resultados para o Brasil. Ministério do Trabalho e Emprego e IPEA. Rio de Janeiro, 2002. 143 p. (p. 01-49).

GORDON, T. J.; HELMER, O.; DALKEY. Estruturando um processo de uma comunicação do grupo para tratar de um problema complexo. Disponível em http://www.12manage.com/methods_helmer_delphi_method_pt.html. 
HLUCHY, L.; HABALA, O.; SIMO, B.; ASTALOS, J.; TRAN, V.D.;DOBRUCKY, M. Problem-solving environment for flood forecasting. Management of Environmental Quality: An International Journal, v. 15, n. 3, p. 268 - 275, 2004.

IBGE. Base de informações por setor censitário - Censo demográfico 2000 Resultados do universo - Rio de Janeiro. IBGE, Rio de Janeiro, 2002. 2 CDROMs.

IBGE. Indicadores Sociais Mínimos.

Disponível em

<http://www.ibge.gov.br/home/estatistica/populacao/condicaodevida/indicadoresmini mos/conceitos.shtm>. Consultado em 05/01/2008.

$I_{B G E}^{2}$. Estatcart: Sistema de recuperação de informações georreferenciadas. Versão 1.1. IBGE, Rio de Janeiro, 2002. 1 CD-ROM.

$I_{B G E}^{3}$. Pesquisa nacional de saneamento básico 2000. IBGE, Departamento de População e Indicadores Sociais. Rio de Janeiro, 2002. 431 p.

IBGE. Indicadores de desenvolvimento sustentável - Brasil 2004. Série estudos e Pesquisas - Informação Geográfica. Rio de Janeiro, 2004. 191 p.

IPEA. Desenvolvimento humano e condições de vida: indicadores brasileiros. IPEA-Fundação João Pinheiro-PNUD-IBGE. Brasília, 1998. 140 p. (Livro e CD$\mathrm{ROM})$.

INTERNATIONAL STRATEGY FOR DISASTER REDUCTION - ISDR.

Disponível em <http://www.unisdr.org/eng/about_isdr/isdr-mission-objectiveseng.htm>. Consultado em: 10 de dezembro de 2007.

INTERNATIONAL STRATEGY FOR DISASTER REDUCTION - ISDR. Living with risk: a global review of disaster reduction initiatives. Geneva: UN/ISDR, 2004. $8 p$.

MARCELINO, E.V.; GOERL, R.F.; RUDORFF, F.M. Distribuição espaço-temporal de inundações bruscas em Santa Catarina. In: SIMPÓSIO BRASILEIRO DE DESASTRES NATURAIS, 2004. Florianópolis. Anais... Florianópolis: GEDN/UFSC, 2004. p 554-564.

MARCELINO, E.V. Desastres Naturais e Geotecnologias: Conceitos Básicos. CRS/INPE. Santa Maria, 2007. 20 p.

MARCH, F.T.H. Social Housing on Slopes. Relatório Final Completo. Alfa-Aurora Project, 2006. 36p.

MARINO, T.B. Vista Saga 2005 - Sistema de Análise Geo-Ambiental. Projeto Final de Graduação. Departamento de Ciência da Computação. Universidade Federal do Rio de Janeiro. Rio de Janeiro, 2005. 
MARINO, T.B.; PAULA, L.N. Manual Operacional do VISTA/SAGA. Universidade Federal do Rio de Janeiro. Rio de Janeiro, 2007.

MEDINA E. Lecture Notes. Dept. of Geography, University of Maryland, 2003. Disponível <www.geog.umd.edu/webspinner/medina/geog371/lecture/lecture8b.pdf>. Consultado em 15/01/2008.

MELO FILHO, J.A. Qualidade de vida na região da Tijuca, RJ, por Geoprocessamento. Tese (doutorado) - Universidade Federal do Rio de Janeiro, 2003. 288 p.

MONTOYA, M.A.P.; CLAROS, M.E.A.C.; MEDEIROS, J.S. de. Identificacion de las áreas con riesgo de inundacion y deslizamiento en la cuenca del Rio Buquira en el Municipio de São José dos Campos - SP utilizando las tecnicas de sensoriamento remoto y geoprocesamiento. São José dos Campos. INPE. 1999. Trabalho do Curso Internacional em Sensoriamento Remoto do INPE.

NOBREGA, R.A.A. Detecção da malha viária na periferia urbana de São Paulo. Tese (doutorado) - Escola Politécnica da Universidade de São Paulo. São Paulo, 2007. 157p.

NOBREGA, R. A. A. ; BARROS, M. T. L. ; QUINTANILHA, J. A. . Emprego de técnicas digitais para a concepção da base cartográfica da bacia hidrográfica do Córrego Cabuçu de Baixo São Paulo SP. Revista Ambiente e Água An Interdisciplinary Journal of Applied Science, v. 3, p. 76-90, 2008.

NOGUEIRA, F.R. Políticas públicas municipais para gerenciamento e riscos ambientais associados a escorregamentos em áreas de ocupação subnormal. Rio Claro. 256p. Tese (Doutorado em Geociências Meio Ambiente) - Universidade Estadual Paulista, 2002.

OGURA, A.T. et al. 2006. Apostila do Curso de Capacitação em Mapeamento e Gerenciamento de Risco na modalidade à distância. Ministério as Cidades, Instituto de Pesquisas Tecnológicas - IPT, Centro de Pesquisas Sobre Desastres Naturais - CEPED, $122 \mathrm{p}$.

PELOGGIA, A. O homem e o ambiente geológico: geologia, sociedade e ocupação urbana no município de São Paulo. São Paulo: Xamã, 1998.271p.

QUINTANILHA, J.A. ; OHARA, C.G. ; NOBREGA, R.A.A. . Detecção de vias em áreas na periferia de São Pulo através de classificação em imagens orbitais baseada em objetos. In: XX ANPET - Congresso de Pesquisa e Ensino em Transportes, 2006, Brasília. Anais do XX ANPET - Congresso de Pesquisa e Ensino em Transportes, 2006. v. 1. p. 679-690.

QUINTANILHA, J.A.; RODRIGUES, M. PTR2389 - Geoprocessamento para Engenharia Ambiental. Notas de Aula de Graduação da Escola Politécnica, 2007.

RAMALHO, J.P.; ISSA, F.M.R.; PEREIRA, M.C.; BRANDI, S.D.; GARCIA, C.; JÚNIO, F.K. - Uma Proposta para a Comparação de Performance entre Redes 
Neurais Artificiais, VI Simpósio Brasileiro de Automação Inteligente, Bauru - SP, Setembro de 2003.

RODRIGUES, M.A modelagem de dados Espaciais. Fator GIS: A Revista do Geoprocessamento, a.2, n.5, p.39-40, 1994.

RODRIGUES, M.; NETO, S.L.R. Um Modelo Conceitual para Integração de Modelos Científicos e Informação Geográfica. Geoinfo 2001 - II Brazilian Symposium on Geolnformatics. 2001.

ROCHA, G.C. Riscos Ambientais: Análise e Mapeamento em Minas Gerais. Ed. UFJF. Juiz de Fora, 2005. 126 p.

SAHOO, N.R.; JOTHIMANI, P.; TRIPATHY, G.K.. Multi-criteria analysis in GIS environment for natural resource development - a case study on gold exploration. Tata Infotech Ltd, SEEPZ, Mumbai, 2002.

SÁNCHEZ, L.E. Avaliação de Impacto Ambiental. Ed. Oficina de Textos, 2006. 495p.

SAWYER, D. População e meio ambiente na Amazônia brasileira. In: MARTINE, G. População, meio ambiente e desenvolvimento - verdades e contradições. Ed. UNICAMP. Campinas, 1993. p.149-167.

SCALP, M. Eliciting expert's knowledge: a comparison of two methods. Technological Forecasting \& Social Change, v. 73, p. 679-704

SECRETARIA DO VERDE E DO MEIO AMBIENTE. Vegetação Significativa do Município de São Paulo. Série Documentos, Secretaria do Meio Ambiente, 1988, São Paulo, 560p.

SMOLKA, M.O. Meio ambiente e estrutura intra-urbana. In: MARTINE, G. (org.) População, meio ambiente e desenvolvimento - verdades e contradições. (Cap. V) Ed. UNICAMP. Campinas, 1993. p.133-143.

SOUZA M.J.L.; XAVIER DA SILVA, J. Análise ambiental. UFRJ, Rio de Janeiro, 1987. 199p.

SOARES FILHO, B.S. Modelagem de Dados Espaciais. Curso de Especialização em Geoprocessamento. Belo Horizonte - MG. Departamento de Cartografia - Centro de Sensoriamento Remoto, 2000. 15p.

TAVARES, W.N. ; QUINTANILHA, J. A. Incorporação de dados sócio-econômicos às informações de variação e expansão do uso do solo urbano na bacia hidrográfica do Córrego Cabuçu de Baixo - São Paulo. In: 12. SIMPÓSIO INTERNACIONAL DE INICIAÇÃO CIENTÍFICA DA USP, 2004, São Paulo. Resumos.

TOBIN, G.A; MONTZ, B.E. Natural hazards: explanation and integration. New York: The Guilford Press, 1997. 388p. 
TOMLIN, D. The Raster GIS. Em NCGIA Core Curriculum, Introduction to GIS, editado por M. F. Goodchild, K. K. Kemp (Santa Barbara, CA: National Center for Geographic Information and Analysis), 4-1:9. 1991.

THOMÉ, R. Interoperabilidade em Geoprocessamento: Conversão entre modelos conceituais de Sistemas de Informação Geográfica e comparação com o padrão Open GIS. Dissertação de Mestrado em Computação Aplicada. São José dos Campos, 1998. 200p.

UNDP - UNITED NATIONS DEVELOPMENT PROGRAMME. Reducing disaster risk: a challenge for development. New York, USA: UNDP, 2004. 129p.

XAVIER DA SILVA, J., CARVALHO FILHO, L.M. Sistemas de informação geográfica: uma proposta metodológica. IV Conferência latino-americana sobre sistemas de informação geográfica. ${ }^{2}$ SIMPÓSIO BRASILEIRO DE GEOPROCESSAMENTO, 7 a 9/07/1993. Anais. São Paulo, 1993, p. 608-629.

XAVIER DA SILVA, J. Geoprocessamento para análise ambiental. Ed. do Autor, Rio de Janeiro, 2001. 227 p.

XAVIER DA SILVA, J. Inclusão Geográfica no Planejamento: do Dado à Informação. Anais do VIII Encontro Gaúcho de Agrimensura e Cartografia. Santa Maria, RS, 2007.

XAVIER DA SILVA, J.; ZAIDAN, R. T. Geoprocessamento para Análise Ambiental: Aplicações. $2^{a}$ Edição. Bertrand Brasil. Rio de Janeiro, 2007. 363 p.

ZADEH, L.A. Fuzzy sets. In: Information and Control. Berkeley, 1965, p. 338-353.

ZERGER, A.; WEALANDS, S. Beyond Modelling: Linking Models with GIS for Flood Risk Management. Natural Hazards, v. 33, 2004, p. 191-208. 